\title{
LA PESTE NEGRA DEL TOMATE Y MORRÓN: APORTES EXPERIMENTALES PARA SU MANEJO INTEGRADO
}
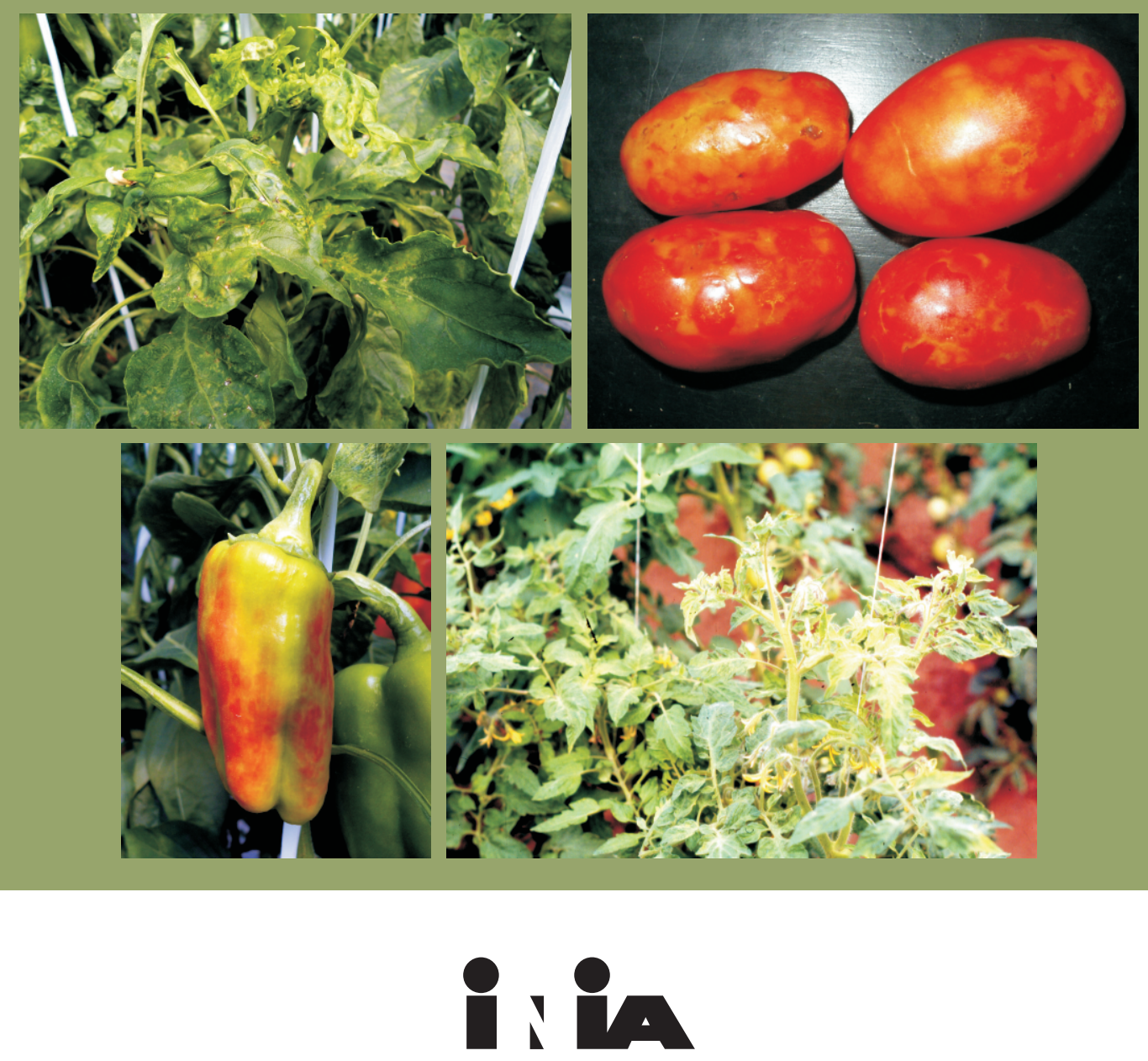

Instituto Nacional de Investigación Agropecuaria

$U R \cup G \cup A Y$ 


\section{LA PESTE NEGRA DEL TOMATE Y MORRÓN: APORTES EXPERIMENTALES PARA SU MANEJO INTEGRADO}

Diego César Maeso Tozzi* 
(C)2021, INIA

e-ISBN: 978-9974-38-454-5

Doi: http://doi.org/10.35676/INIA/PNMT

Editado por la Unidad de Comunicación y Transferencia de Tecnología de INIA.

Instituto Nacional de Investigación Agropecuaria.

Avda. Italia 6201, Edificio Los Guayabos, Parque Tecnológico del LATU,

Montevideo - Uruguay

www.inia.uy

Cita correcta: MAESO, D. 2021. La peste negra del tomate y morrón: Aportes experimentales para su manejo integrado. Montevideo (UY): INIA. 183 p. 


\section{Instituto Nacional de Investigación Agropecuaria}

\section{Integración de la Junta Directiva}

Ing. Agr. José Bonica - Presidente

Ing. Agr. Walter Baethgen - Vicepresidente

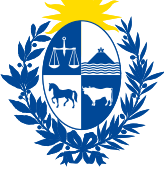

Ministerio

de Ganadería,

Agricultura y Pesca

Ing. Agr. Rafael Secco

Ing. Agr. Martín Gortari
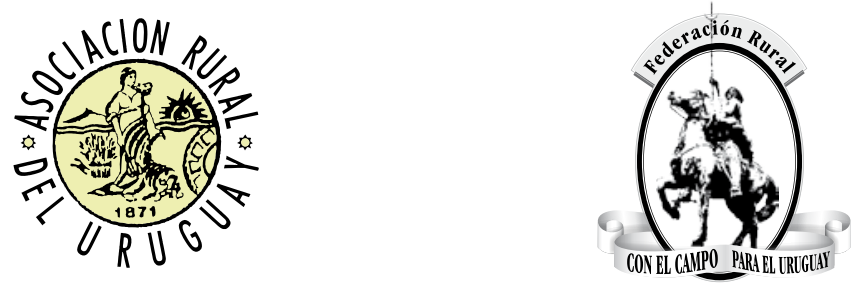

Ing. Agr. Alberto Bozzo

Ing. Agr. Alejandro Henry
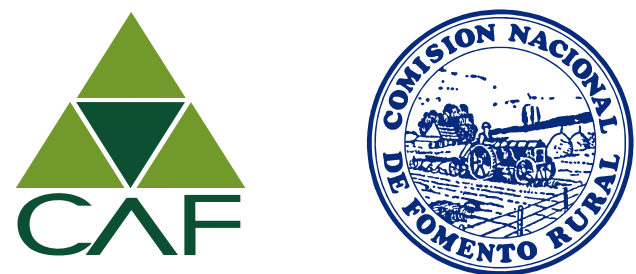



\section{Indice}

LISTA DE CUADROS.

LISTA DE FIGURAS

PRÓLOGO

INTRODUCCIÓN

IMPORTANCIA Y DISTRIBUCIÓN MUNDIAL

SÍNTOMAS

Tomate

Morrón.

Lechuga.

ORGANISMOS CAUSALES.

Características de las partículas de Orthotospovirus

Especies de Orthotospovirus que afectan tomate y morrón en la región.

MÉTODOS DE DETECCIÓN.

Plantas indicadoras.

Técnicas serológicas

Reacción en cadena de la polimerasa (PCR)

FACTORES QUE INFLUYEN EN EL DESARROLLO E INTENSIDAD DE SÍNTOMAS

Edad de la planta

Condiciones ambientales

Duración entre la inoculación y aparición de síntomas.

CICLO DE LA ENFERMEDAD Y EPIDEMIOLOGÍA

INSECTOS VECTORES...

Especies de trips trasmisores.

Influencia de las condiciones ambientales en el ciclo de vida de los trips......

Diferencias en la capacidad trasmisora.

Adquisición.

Procesos dentro del vector

Trasmisión

HUÉSPEDES

Presencia de trips y Orthotospovirus en malezas en invernáculos de la zona sur de Uruguay.

1) Malezas hospederas de especies de trips vectores asociadas a cultivos de morrón en la zona sur de Uruguay

2) Especies de trips presentes en las malezas relevadas 
3) Determinación de la infección con Orthotospovirus en malezas asociadas a cultivos de morrón en invernáculo.

EPIDEMIOLOGÍA

Características del ciclo de peste negra de tomate y morrón ..................................... 84

Papel del vector en el ciclo epidemiológico .............................................................. 90

a) Origen de la migración inicial de vectores al cultivo ................................... 90

1. Migración desde el exterior ........................................................................... 91

2. Permanencia en el interior de los invernáculos ............................................. 97

a. Pupas en el inicio de epidemias en nuevos cultivos ..................................... 97

b. Huéspedes alternativos en el interior de los invernáculos ............................ 100

c. Transmisión desde frutos ......................................................................... 101

3. Evolución de la población del vector y la enfermedad en la estación de cultivo.... 101

a. Efecto de la temperatura en la población del vector en el interior de los invernáculos

b. Probables fuentes internas de los vectores..................................................

c. Proporción de vectores infectivos frente al número total de individuos presentes en cultivo

Secuencia de eventos en el desarrollo de un ataque de peste negra ......................... 108

\section{MANEJO}

Monitoreo de trips y síntomas.....

Eliminación de fuentes de virus y trips entre cultivos.....

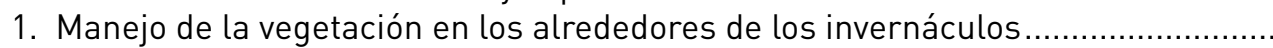

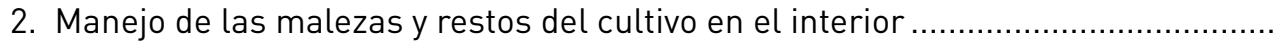

3. Intervalo entre cultivos y rotaciones

Medidas en el diseño y ejecución de la plantación

1. Orientación y diseño de las filas

2. Distancia entre cultivos...

3. Barreras físicas

Medidas durante el cultivo

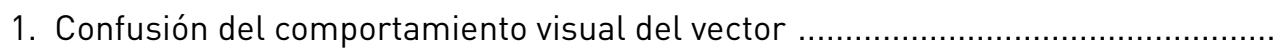

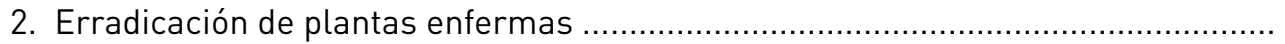

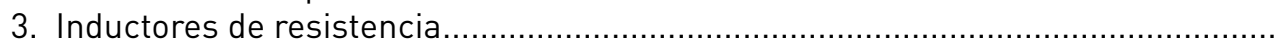

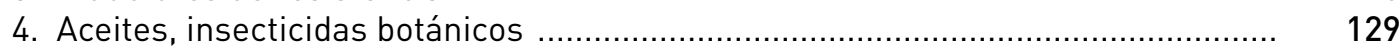

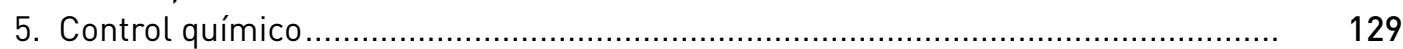

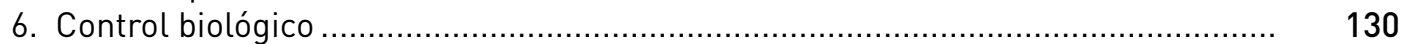

Resistencia genética.................................................................................. 132

1. Resistencia a trips ....................................................................................... 132

2. Resistencia a orthotospovirus en tomate y morrón ............................................... 133

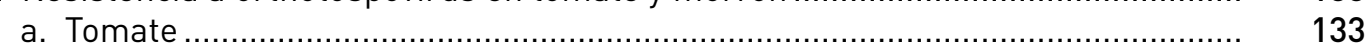

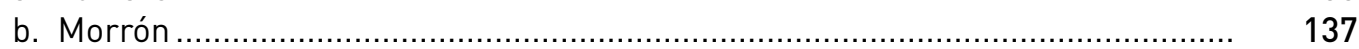

3. Quiebre de resistencia ................................................................................ 139

Enfoques moleculares para el manejo............................................................. 143

Producción agroecológica y enfermedades a virus en tomate ................................. 143 
ÍNDICES DE RIESGO

Aproximación al diseño de un índice de riesgo para peste negra en cultivos de tomate y morrón en invernáculo en la zona sur de Uruguay. 


\section{Lista de cuadros}

Cuadro 1. Lista de especies de Orthotospovirus reportados y su origen geográfico (adaptada de Turina et al.; 2016; Pappu et al.; 2009)

Cuadro 2. Detección de especies de Orthotospovirus en muestras de plantas de tomate y morrón con síntomas de peste negra en Uruguay

Cuadro 3. Síntomas en algunas de las plantas indicadoras comúnmente usadas ladaptado de Lasa,1982; Kormerlink, 2005; IPPC, 2017)....

Cuadro 4. Duración del ciclo de vida de tres especies de trips vectores de peste negra (adaptado de Rosello et al., 1996)

Cuadro 5. Malezas relevantes como huéspedes alternativos en el desarrollo de epidemias de enfermedades causadas por orthotospovirus en cultivos comerciales ....

Cuadro 6. Especies de malezas prevalentes en el interior de invernaderos de morrón del departamento de Canelones durante el período setiembre 2017-2019.

Cuadro 7. Especies de malezas prevalentes en el exterior de invernaderos de morrón del departamento de Canelones durante el período setiembre 2017-2019.

Cuadro 8. Contribución de las diferentes especies de malezas encontradas en el interior de invernaderos de morrón del departamento de Canelones al número total de trips determinado en flores en cada estación durante el período setiembre 2017-2019.

Cuadro 9. Contribución de las diferentes especies de malezas encontradas en el exterior de invernaderos de morrón del departamento de Canelones al número total de trips determinado en flores en cada estación durante el período setiembre 2017-2019.

Cuadro 10. Especies de trips identificadas en algunas de las malezas registradas en el seguimiento 2017-2019 de los invernaderos según estación.....

Cuadro 11. Detección de orthotospovirus mediante DAS-ELISA en malezas con síntomas atribuibles a virosis asociadas a un cultivo de morrón en invernáculo en Canelón chico en el ciclo 2011-2012

Cuadro 12. Información para el análisis del ataque de peste negra a dos cultivos de morrón en invernáculos de Canelón Chico en 2011-12 y 2012-13 
Cuadro 13. Información para el análisis del ataque de peste negra en ocho cultivos de tomate evaluados en el período 1998-2005

Cuadro 14. Determinación de la capacidad de trasmisión de peste negra y su relación con la presencia de trips

Cuadro 15. Evolución de la población de trips capturados en trampas cromáticas con pegante (tomado de Buenahora et al.; 2003b).

Cuadro 16. Información relevante de la evolución de síntomas de peste negra en cultivos de morrón en invernadero estudiados en el período 2011-2014

Cuadro 17. Resultados de inoculaciones de cultivares comerciales con orthotospovirus

Cuadro 18. Medidas de manejo integrado para minimizar los ataques de peste negra en cultivos hortícolas en tres situaciones: almácigos, cultivos protegidos y a campo (Tomada de Jones, 2004) 


\section{Lista de figuras}

Figura 1. Distribución mundial de TSWV (fuente EPPO Global data base 2020 versión 05 04 2020, https://gd.eppo.int/taxon/TSWV00/distribution).....

Figura 2. Lesiones necróticas y secado de follaje en plantas jóvenes de tomate.

Figura 3. Coloración violácea-bronceada de nervaduras y ápice.

Figura 4. Coloración violácea-bronceada en brotes de plantas de tomate.

Figura 5. Lesiones necróticas con diversos patrones en folíolos.

Figura 6. Marchitamiento apical en plantas enfermas de peste negra

Figura 7. Anillos cloróticos en hojas de tomate

Figura 8. Mosaico foliar en plantas con peste negra.

Figura 9. Encrespado de ápice en plantas de tomate provocado por peste negra

Figura 10. Abultamientos en sectores de folíolos en hojas de tomate

Figura 11. Epinastia y enrollado de hojas en plantas afectadas por peste negra

Figura 12. Plantas achaparradas en focos asociados a la cercanía con fuentes de inóculo.

Figura 13. Presencia de manchas anilladas concéntricas de color amarillo en frutos inmaduros.

Figura 14. Manchas anilladas en frutos maduros.

Figura 15. Deformación de frutos de tomate en plantas afectadas con peste negra......

Figura 16. Evolución de síntomas en cultivos afectados con peste negra ltodas las plantas incluidas en los estudios fueron positivas en pruebas serológicas de laboratorio)

Figura 17. Vista general de los cultivos en los que se realizaron los registros de evolución de síntomas. Invernáculo en INIA Las Brujas e invernáculo comercial en Arenales, (departamento de Canelones)

Figura 18. Síntomas de peste negra en plantines de morrón en las primeras etapas pos-trasplante 
Figura 19. Enanismo, deformación foliar y dibujos cloróticos en plantines de morrón en las primeras etapas postrasplante

Figura 20. Síntomas de peste negra en plantines de morrón, deformación y coloración anormal de hojas y detención del crecimiento

Figura 21. Enanismo y crecimiento anormal de plantas afectadas por peste negra .......

Figura 22. Detención de crecimiento, enanismo y muerte de brotes en plantas de morrón con peste negra

Figura 23. Dibujos de coloración amarilla en hojas de plantas de morrón con peste negra

Figura 24. Coloración amarilla atenuada y necrosis de tejidos en hojas que previamente presentaban mosaicos y dibujos

Figura 25. Deformación foliar acompañada de mosaicos y coloraciones amarillentas.....

Figura 26. Enanismo, crecimiento distorsionado, deformación foliar y muerte de brotes

Figura 27. Deformación y necrosis de frutos de morrón provocada por peste negra .....

Figura 28. Necrosis de frutos de morrón provocada por peste negra

Figura 29. Coloración irregular en frutos de morrón en plantas infectadas tardíamente con peste negra

Figura 30. Frutos con coloración irregular por ataques tardíos de peste negra cosechados para su comercialización.

Figura 31. Síntomas de peste negra en lechuga 38

Figura 32. Partícula de TSWV observada al microscopio electrónico.....

Figura 33. Esquema ilustrativo de la composición de una partícula de orthostospovirus.

Figura 34. Lesiones locales desarrolladas en diferentes plantas indicadoras luego de la inoculación mecánica con orthotospovirus. Nicotiana glutinosa y Petunia hybrida

Figura 35. Síntomas sistémicos en algunas plantas indicadoras herbáceas. Nicotiana spp. y Datura stramonium

Figura 36. Detección serológica de orthotospovirus 50

Figura 37. Detección serológica de orthotospovirus en trips mediante la técnica NCELISA. 
Figura 38. Detección molecular de orthotospovirus en Uruguay

Figura 39. Duración del período desde la detección de TSWV (mediante técnica DAS ELISA) a la aparición de síntomas (días) y evolución del porcentaje de plantas infectadas en experimentos de seguimiento de ataques en tomate en invernadero (1998-2000) ....

Figura 40. Especies de trips presentes en flores de morrón y malezas por estación. ...

Figura 41. Lesiones en hojas de trébol blanco, corregüela y fruto de morrón ocasionadas por la alimentación de trips

Figura 42. Ciclo de Frankliniella spp. relacionado con la trasmisión de peste negra (modificado de Peters, 2003)

Figura 43. Presencia de plantas de un cultivo luego de su finalización

Figura 44. Períodos de floración de las malezas prevalentes en el trabajo de seguimiento 2017-2019

Figura 45. Períodos de floración de las malezas prevalentes con mayor aporte de trips registradas en el trabajo de seguimiento 2017-2019

Figura 46. Principales malezas con presencia y hospedadoras de trips en invierno presentes fundamentalmente en el interior de los invernáculos durante el seguimiento 2017-2019

Figura 47. Principales malezas con presencia y hospedadoras de trips con floración en varias estaciones, invierno incluido, presentes durante el seguimiento 2017-2019 .......

Figura 48. Especies de trips identificadas en flores morrón y de malezas asociadas al cultivo. Izquierda: F. occidentalis, derecha: T. tabaci, abajo: F. schultzei. Fotos V. Galván..

Figura 49. Número de plantas de malezas asociadas a un cultivo de morrón en invernadero en Canelón Chico en las que se detectó TSWV por DAS-ELISA según estaciones

Figura 50. Localización de las malezas donde se detectó TSWV durante el ciclo 2011 2012 en un cultivo de morrón en invernáculo en Canelón Chico.

Figura 51. Síntomas observados en algunas de las malezas asociadas con un cultivo de morrón en invernadero en las que se detectó TSWV mediante DAS-ELISA

Figura 52. Algunos ejemplos de la presencia de malezas en floración afuera de invernáculos vacíos durante invierno

Figura 53. Efecto de las heladas sobre las malezas en el exterior de los invernáculos .

Figura 54. Presencia de malezas en invierno adentro de los invernáculos sin cultivo ... 
Figura 55. Cultivo de lechuga trasplantado al lado de un cultivo de tomate con una incidencia alta de peste negra en un invernadero de la zona de Arenales, departamento de Canelones que desarrolló la enfermedad a los pocos días

Figura 56. Evolución del porcentaje de plantas de lechuga con peste negra trasplantadas luego de un cultivo de tomate de la variedad Valeria con $70 \%$ de ataque de la enfermedad.

Figura 57. Detalle del ataque de peste negra en las dos filas contiguas a la pared exterior en un invernadero de Canelón Chico durante 2018

Figura 58. Incidencia de peste negra en un cultivo de morrón durante 2018 en un invernáculo en Canelón Chico.....

Figura 59. Ataques de peste negra en morrón en forma de focos, algunos reducidos y otros que abarcan varias filas del cultivo

Figura 60. Focos de plantas con peste negra en tomate en bordes del cultivo

90

Figura 61. Evolución de las capturas de trips (en número de trips/día) en trampas amarillas pegajosas colocadas en las paredes externas de invernáculos dedicados a la plantación de morrón durante el período sin cultivo

Figura 62. Evolución de las capturas de trips en trampas pegajosas amarillas colocadas en el exterior e interior de invernáculos dedicados al cultivo de morrón......

Figura 63. Rectas de regresión y coeficientes de correlación resultado del análisis estadístico de la relación entre los valores de capturas en trampas externas e internas presentados en la Figura 62

Figura 64. Número acumulado de trips capturados en trampas amarillas pegajosas en el exterior de invernáculos de cultivo de morrón en el período junio-octubre en cuatro temporadas y parámetros climáticos relacionados.

Figura 65. Evolución del número promedio de trips capturados en trampas amarillas pegajosas en el exterior de cinco invernáculos del NE de Canelones (NE) y tres de Canelón Chico (Can. Chico) departamento de Canelones durante junio-setiembre 2018 y 2019 y presencia de trips en flores de algunas malezas.

Figura 66. Número de trips/día acumulados entre noviembre y junio en trampas amarillas pegajosas colocadas en el exterior e interior de invernáculos con y sin malla anti-insecto perimetral con cultivos de morrón con diferente orientación......

Figura 67. Disposición de trampas amarillas pegajosas utilizadas para estudiar evolución de capturas de trips en el periodo entre cultivos (agosto-noviembre 2018).... 
Figura 68. Captura promedio de trips (F. occidentalis) en trampas amarillas pegajosas colocadas en diferentes posiciones en un invernáculo entre cultivos de morrón: a nivel de suelo (10 en el hueco de las plantas y 10 en las entre filas), dos a $20 \mathrm{~cm}$ y dos a 150 $\mathrm{cm}$ de altura.

Figura 69. Evolución del número de trips capturados en trampas amarillas pegajosas en el interior de un invernáculo en Canelón Chico en dos posiciones 10,2 y 1,5 m, promedio de dos trampas por posición).

Figura 70. Evolución del número promedio de trips capturados en trampas amarillas pegajosas en el interior de cinco invernáculos del NE de Canelones (NE) y tres de Canelón Chico (Can. Chico) departamento de Canelones durante junio-setiembre 2018 y 2019 y presencia de trips en flores de algunas malezas dentro de los invernáculos ...

Figura 71. Relación entre temperatura y número de trips capturados en trampas amarillas pegajosas ubicadas en el interior de tres invernáculos en Canelón Chico (izquierda) y cinco en el Noreste de Canelones (derecha).

Figura 72. Relación entre la temperatura interior registrada y la captura de trips en trampas pegajosas amarillas en invernáculos del NE de Canelones y Canelón chico....

Figura 73. Evolución del número de trips capturados en trampas pegajosas amarillas en el interior de invernáculos del noreste de Canelones comparado con el número de individuos en flores de morrón y las malezas predominantes (promedio de diez flores por especie)

Figura 74. Evolución del número de trips capturados en trampas pegajosas amarillas en el interior de invernáculos de Canelón Chico comparado con el número de individuos en flores de morrón y las malezas predominantes (promedio de diez flores por especie)..

Figura 75. Captura de trips en trampas amarillas y colecta en flores de tomate y malezas durante cultivos en invernáculo en las temporadas 2003-2004 y 2004-2005 en INIA Las Brujas.

Figura 76. Experimento de seguimiento de un ataque de peste negra en tomate en un invernadero de Rincón del Colorado (Canelones) durante 1997-1998 y 1999-2000. Vista general del experimento, plantas expuestas en evaluación; lesiones desarrolladas en plantas expuestas y plantas expuestas en proximidad de planta con síntomas.

Figura 77. Relación entre el número de trips colectados en trampas amarillas pegajosas en el interior de un invernáculo con el porcentaje de plantas de petunia expuestas que desarrollaron lesiones en un cultivo comercial de tomate variedad Superman durante 1997-98 en Rincón del Colorado (Departamento de Canelones).

Figura 78. Detección de TSWV en trips en relación con la captura en trampa pegajosa. Cultivo a campo, cultivo en macrotúneles

Figura 79. Esquema de eventos en el desarrollo de un ataque de peste negra en cultivos bajo invernáculo en la zona sur de Uruguay.... 
Figura 80. Evolución de la colecta de trips en flores de tomate, malezas, captura en trampas amarillas y detección de TSWV en plantas y trips en tres cultivos de tomate bajo invernáculo en INIA Las Brujas en el período 2003-2005.

Figura 81. Evolución de la colecta de trips en flores de morrón, malezas (número promedio de diez flores y de todas las especies con individuos en sus flores), captura en trampas amarillas (dentro y fuera del invernáculo) y porcentaje de plantas con síntomas de peste negra (sobre un total de 1080 plantas) en un cultivo de morrón en Canelón Chico, período 2017-2019

Figura 82. Trampas amarillas pegajosas para monitoreo de la evolución del número de adultos

Figura 83. Trips en flores de morrón y corregüela

Figura 84. Extracción por golpeo de flores en superficie clara

Figura 85. Control de malezas en la faja externa del invernáculo. Aplicación de herbicida junto a la pared y corte en la inmediación

Figura 86. Problemas de encharcamiento provocados por dejar suelo desnudo alrededor de los invernaderos

Figura 87. Corte de vegetación espontánea en las inmediaciones de los invernaderos. 116

Figura 88. Presencia de trébol blanco en la inmediación de los invernáculos.

Figura 89. Vegetación espontánea y plantas de cultivo abandonado al final de estación.

Figura 90. Remanentes luego de quitar el cultivo anterior. Izquierda, tocones, centro tocón con rebrote con síntomas en su lugar, derecha rebrote en depósito de restos cercano al invernáculo.

Figura 91. Cultivo trasplantado dejando restos del cultivo anterior en la entre fila afectado por peste negra tempranamente

Figura 92. Realización de abonos verdes entre cultivos. Izquierda buen ejemplo, derecha solo en la fila

Figura 93. Solarización en invernáculos dedicados a cultivos hortícolas de verano....... 118

Figura 94. Ejemplos del uso de mallas en almácigos e invernáculos

Figura 95. Tipo de malla utilizada para evitar ingreso de vectores

Figura 96. Diferentes diseños de doble puerta de entrada en invernáculos con malla ...... 
Figura 97. Número de trips/día (número total observado dividido entre intervalo en días entre capturas) capturados en trampas amarillas pegajosas ubicadas en el interior y exterior de invernáculos con cultivos de morrón en tres temporadas (2011-2014).

Figura 98. Vista de algunas de las estaciones con las plantas evaluadas en este experimento

Figura 99. Evolución de la aparición de síntomas de peste negra en un cultivo de morrón realizados con o sin protección perimetral de malla anti-insecto

Figura 100. Diferentes formas de uso de superficies coloreadas pegajosas para captura masiva de vectores

Figura 101. Erradicación de plantas afectadas como medida de control. Corte de la parte aérea, brotación de planta erradicada presentando síntomas

Figura 102. Lesión local necrótica desarrollada por un cultivar con el gen Sw-5 luego de la inoculación mecánica con TSWV

Figura 103. Síntomas de peste negra en frutos de cultivares con el gen $S_{W}-5$

Figura 104. Frutos de tomate tipo Platense

Figura 105. Cultivo de tomate Loica atacado con peste negra. Nótese la falta de necrosis y la producción de frutos

Figura 106. Síntomas atribuibles a la reacción de hipersensibilidad en cultivares de morrón con el gen Tsw.

Figura 107. Evolución del porcentaje de plantas son síntomas de peste negra en invernáculos de morrón en Canelón Chico (Departamento de Canelones) en diferentes cultivares con resistencia a peste negra durante las temporadas 2011-2013

Figura 108. Temperatura promedio diaria en el período diciembre-enero al interior de los invernáculos estudiados en las tres temporadas

Figura 109. Reacciones a la inoculación mecánica de algunos cultivares de tomate en experimentos 1999. Reacciones de hipersensibilidad típica del gen $S w-5$ exhibida por las variedades resistentes y síntomas sistémicos en cultivares sensibles. 


\section{Prólogo}

La presente publicación tiene como intención poner a disposición de técnicos asesores, productores, estudiantes, investigadores y todos aquellos interesados en el tema, información internacional junto a información local fruto de muchos años de trabajo del autor, colegas y colaboradores en la Estación Experimental Las Brujas (EELB), hoy INIA Las Brujas. La información está resumida y compendiada con las referencias para que, quien lo considere pueda abundar en detalles.

Esta enfermedad, inicialmente considerada como un problema casi exclusivo del hemisferio sur y principalmente de nuestra región, captó nuestro interés desde nuestros comienzos en la EELB, no solo por su importancia, sino por sus características singulares que la diferencian de muchos otros problemas sanitarios como veremos en el desarrollo de esta serie técnica. En ese momento, a comienzos de los años ochenta, estaban en marcha estudios en la EELB acerca de esta virosis dentro de un convenio con la Agencia Japonesa de Cooperación Internacional (JICA) en horticultura, con el respaldo científico de numerosos expertos de primer nivel y de equipamiento de vanguardia similar al de muchos centros del primer mundo, lo cual, en lo personal, fomentó nuestra vocación y entusiasmo por la virología vegetal. Posteriormente se recibieron otros aportes importantes en este tema en el marco de intercambios entre INIA y la Agencia Española de Cooperación Internacional gracias a los cuales recibimos y pudimos visitar a prestigiosos especialistas pertenecientes al Institut de Recerca i Tecnologia Agroalimentàries (IRTA), al Consejo Superior de Investigaciones Científicas (CSIC) La Mayora, al Centro de Investigaciones y Formación Agrícola (CIFA) La Mojonera y al Centro de Investigación y Desarrollo Agrario (CIDA) Murcia, entre otros.

Esos fructíferos intercambios internacionales junto a los aportes de colegas uruguayos y de la región nos permitió diseñar y ejecutar los trabajos de investigación que generaron parte de la información local que aquí se presenta. Mucha de ella ya fue presentada en charlas, reuniones técnicas, congresos, jornadas y demás actividades de difusión mantenidas en casi cuatro décadas de labor. Sin embargo, creímos conveniente su integración, junto a comentarios y observaciones propias de nuestra experiencia y de la bibliografía internacional que ayudará al lector a comprender y 
manejar a esta importante enfermedad. Los detalles de los experimentos incluidos pueden ser encontrados en las Series de Actividades de Difusión (SAD) de INIA correspondientes que aparecen mencionadas en la bibliografía.

Quiero agradecer la invalorable contribución de muchos colaboradores, colegas y estudiantes que, durante todos estos años no solo permitieron la realización de los trabajos experimentales, sino que también los enriquecieron con sus aportes. En ese sentido quiero a agradecer a Wilma Walasek, Alfredo Fernández, Gonzalo Vázquez, Verónica Galván y a los Ing. Agrs. Jorge Arboleya, Jorge Paullier, Roberto Bernal, Leticia Rubio, José Buenahora, Pablo González, Lujan Banchero y Eduardo Campelo. También deseo destacar el apoyo que siempre se recibió desde el Programa de Producción Hortícola incluyendo al manejo integrado de esta enfermedad entre sus prioridades. Por último y por ello no menos importante, nuestro agradecimiento a los productores que de una forma u otra contribuyeron, ya sea prestando sus cultivos para los experimentos, aportando ideas, comentarios y observaciones que muchas veces los investigadores, por estar inmersos en nuestro objetivo específico, pasamos por alto. A todos ellos y, a los que seguramente me olvidé de mencionar, ¡muchas gracias! 


\section{Dntroducción}

La enfermedad que conocemos con el nombre de "peste negra", también denominada en otras regiones como "bronceado", "corcovo" o "viracabeça" fue descrita por primera vez en 1915 en Australia (Brittlebank, 1919). Hasta 1930 no se conoció su naturaleza viral (Samuel et al., 1930), y por muchos años permaneció como un problema importante solo para determinadas regiones, entre ellas el Río de la Plata. Es por eso por lo que muchas de las primeras informaciones provinieron de Australia y Argentina, así como las primeras referencias a materiales de tomate resistentes ("platenses").

En Uruguay fue mencionada por primera vez en 1944 como una de las principales enfermedades de la agricultura en el país (Bertelli y Koch de Bertelli, 1944). Dada su importancia para varios cultivos hortícolas es que en la década de los 80 se realizan los primeros estudios por parte de la Estación Experimental Las Brujas (Lasa y Tezuka, 1980; Lasa et al., 1981; Lasa, 1982; Lasa y Núñez, 1982; Lasa y Francis, 1983; Tezuka y Lasa, 1983).

Desde ese entonces varios han sido los cambios introducidos en los cultivos hortícolas en cuanto a cultivares y formas de producción. A partir de la comercialización de variedades resistentes en la década de los noventa la enfermedad dejó de ser un problema para la producción de tomate de mercado, perjudicando solamente al tomate para industria y algunos tipos especiales, para los cuales luego también fueron surgiendo variedades resistentes. Algo similar ocurrió con el cultivo de morrón, pero, en ese caso la resistencia no fue tan efectiva por lo que, como veremos, la enfermedad continúa provocando importantes pérdidas.

Uno de los grandes cambios para la horticultura fue la difusión del cultivo en invernáculo lo cual ha generado algunas situaciones particulares favorables para la ocurrencia de peste negra. Entre otras cosas, permitió la presencia de plantas de cultivos hortícolas sensibles de diferentes edades, prácticamente durante casi todo el año, e incluso, la rotación con cultivos cortos sensibles como lechuga, buscando el uso casi permanente de la superficie cubierta. También la plantación en invernadero permite la presencia de malezas hospederas del virus y de su vector durante todo el año, no cortando el ciclo de la enfermedad. Es así como se han visto ataques importantes en cultivos de lechuga (Maeso y 
Caro, 1997), acelga, apio y varios otros cultivos menores que comparten la misma estructura. Otro cambio reciente es la difusión de la producción comercial de plantines, la cual, si es mal manejada, implica un riesgo sanitario dada la acumulación de infinidad de plantas en una misma estructura en forma permanente y secuencial que luego serán distribuidas a infinidad de productores, y potencialmente puede dar lugar a infecciones masivas.

Otro de los factores que ha incrementado la importancia y distribución de la enfermedad a nivel mundial fue la diseminación, también a comienzos de la década de los 90, de uno de sus vectores más eficaces: Frankliniella occidentalis, los problemas en el control químico de trips por la resistencia a insecticidas y la limitación o prohibición de muchos principios de uso frecuente para evitar problemas de salud y ambientales.

En esta publicación se incluyen las principales referencias internacionales de forma de brindar información actualizada útil desde el punto de vista productivo, junto a información nacional fruto del trabajo del autor y de varios prestigiosos investigadores del INIA y de su predecesor el CIAAB. Ésta comprende desde aportes al conocimiento de los virus implicados, vectores y datos epidemiológicos con el objetivo de contribuir a un manejo integrado de la enfermedad preventivo y sustentable. 


\section{IMPORTANCIA Y DISTRIBUCIÓN MUNDIAL}

La "peste negra" puede catalogarse como una de las enfermedades más importantes en muchos cultivos, no solo hortícolas (Roselló et al., 1996; Adkins, 2000) sino también extensivos (tabaco, maní, legumbres) y ornamentales. Ha sido considerada como la segunda entre las diez virosis vegetales más relevantes (Scholthof et al., 2011).

Produce grandes pérdidas en tomate, morrón y lechuga, las cuales, dependiendo de la sensibilidad del cultivar y del momento en que ocurre la infección, pueden ser totales, disminuir los rendimientos o solamente afectar la calidad de la producción. Los ataques están muy relacionados con la presencia de fuentes de inóculo y del vector, así como de las condiciones ambientales (fundamentalmente la temperatura) por lo que comúnmente se asocian a determinadas zonas o temporadas.

En Uruguay ocurre en casi todo el territorio (Lasa, 1982) siendo particularmente importante en las zonas hortícolas del sur (Montevideo, Canelones, San José, Florida) y del norte (Salto y Bella Unión). A nivel mundial la enfermedad se distribuye prácticamente en casi todas las regiones existiendo diferencias en cuanto a los agentes causales (EPPO, 2020, Figura 1).

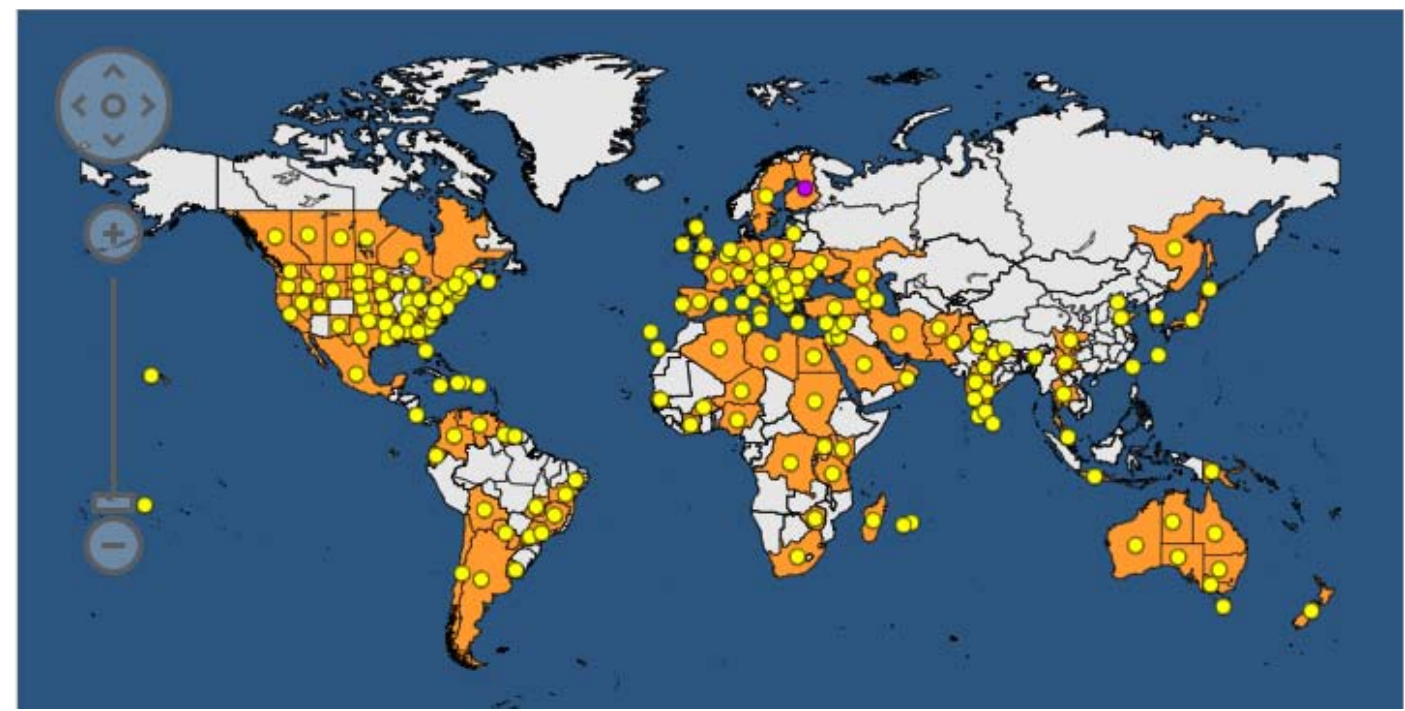

Figura 1. Distribución mundial de TSWV (fuente EPPO Global data base 2020 versión 0504 2020, https://gd.eppo.int/taxon/ TSWV00/distribution). Círculos amarillos = presente. Distribución de GRSV: Ghana, Sudáfrica, Argentina, Brasil, Paraguay, EE. UU. y Finlandia y de TCSV: Sudáfrica, Argentina, Brasil, Cuba, República Dominicana, Haití, Puerto Rico, EE. UU.; Austria y Bélgica. 


\section{SÍNTOMAS}

Como ocurre con la gran mayoría de las enfermedades ocasionadas por virus, el tipo y la intensidad de los síntomas dependen de la variante del virus involucrada, de la edad de la planta a la infección (cuanto más joven mayor intensidad) y de las condiciones ambientales Igeneralmente temperaturas muy bajas o altas no favorecen la multiplicación del agente causal). A continuación, describiremos los síntomas en los cultivos de nuestro interés.

\section{Tomate}

Los síntomas más severos se presentan cuando la infección ocurre en los primeros 45 días de vida de la planta. Aparecen manchas necróticas amorfas en las hojas jóvenes que luego confluyen secando áreas importantes (Figura 2).

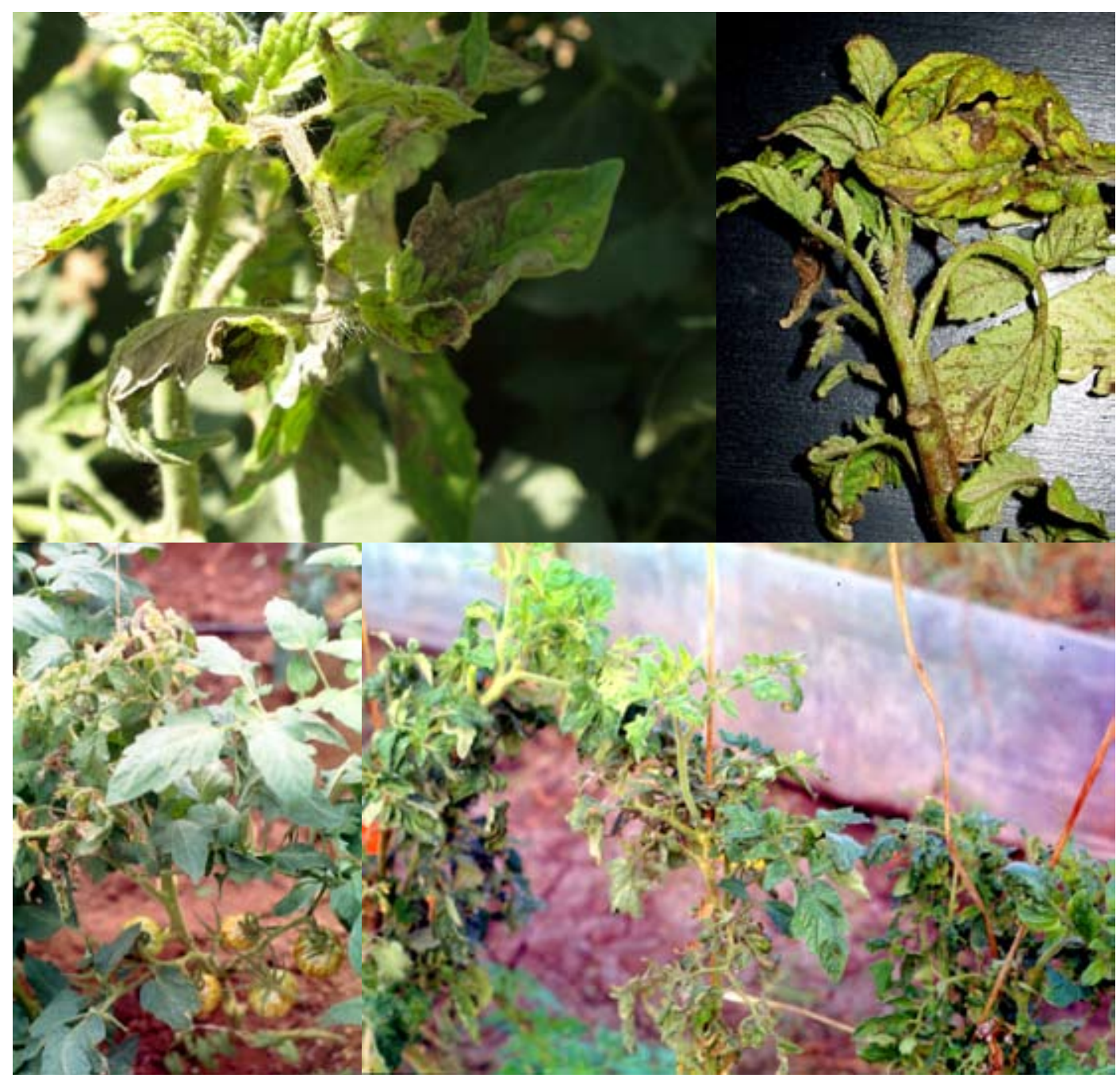

Figura 2. Lesiones necróticas y secado de follaje en plantas jóvenes de tomate. Fotos D. Maeso. 
Al mismo tiempo aparecen manchas en tallos, pecíolos y raquis que toman coloración violácea a bronceada, de ahí el nombre de "bronceado" que recibe la enfermedad en algunas regiones (Figura 3). A veces, los brotes solamente tienen una apariencia rara con coloración violácea que no corresponde a la deficiencia de nutrientes, una de las causas más comunes de confusión (Figura 4).

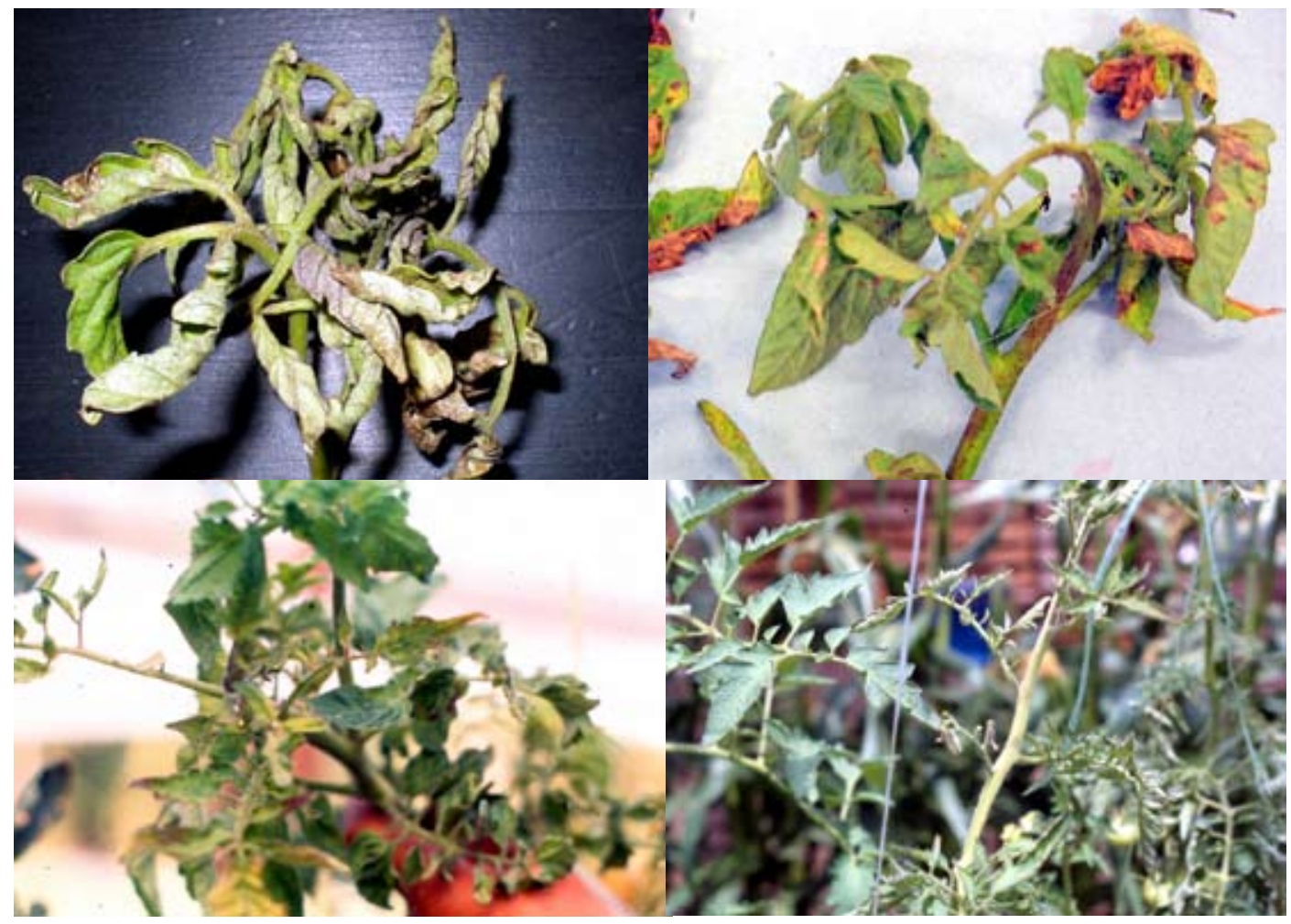

Figura 3. Coloración violácea-bronceada de nervaduras y ápice. Fotos D. Maeso

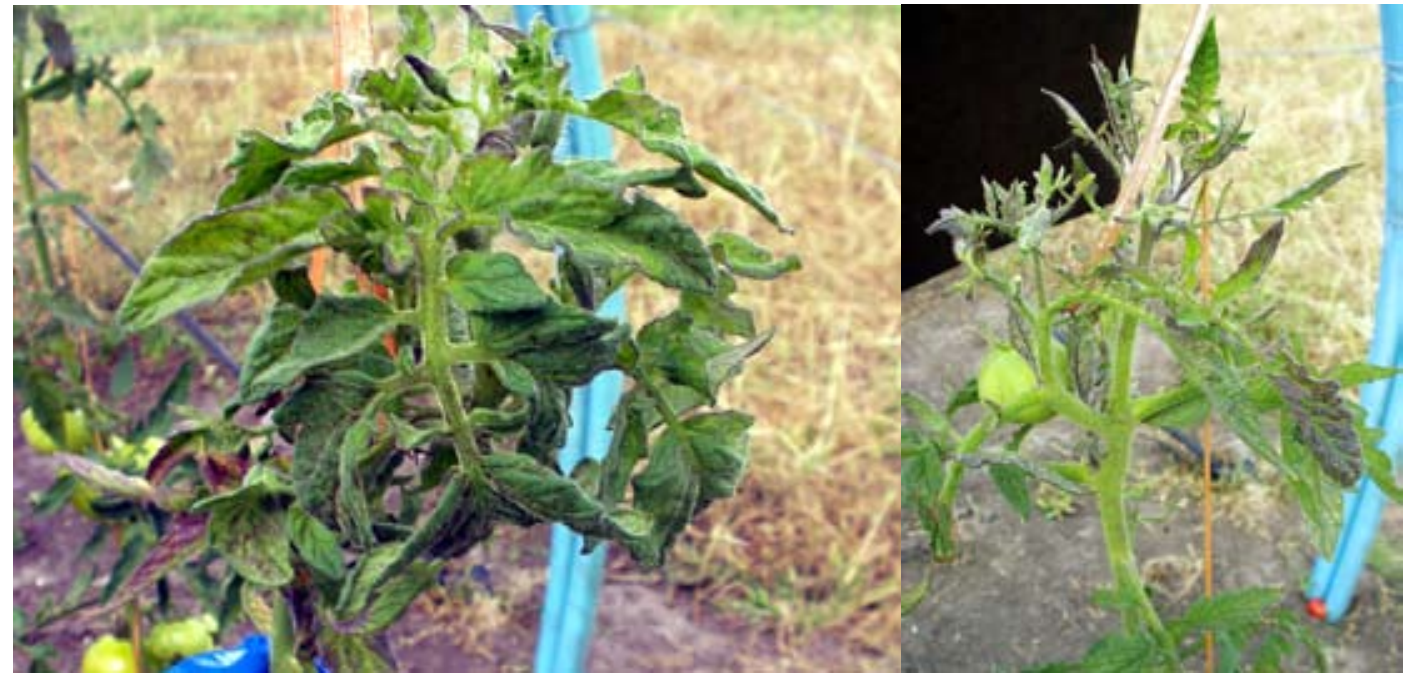

Figura 4. Coloración violácea-bronceada en brotes de plantas de tomate. Fotos D. Maeso. 
Las lesiones necróticas en los folíolos pueden ser amorfas, seguir las nervaduras o formar patrones o dibujos (Figura 5) por lo que muchas veces pueden ser confundidas con las producidas por otras enfermedades (p.ej. alternaria).

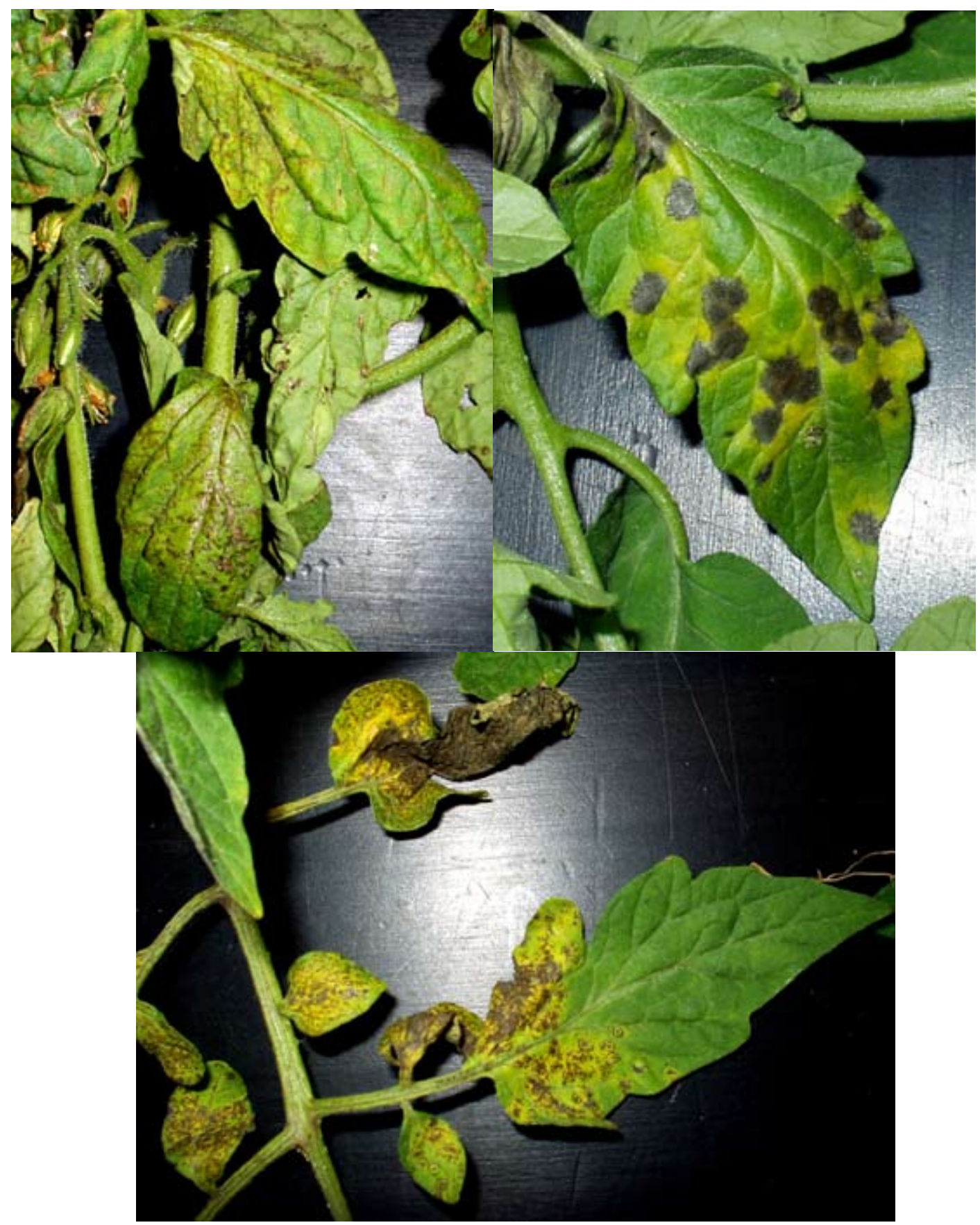

Figura 5. Lesiones necróticas con diversos patrones en folíolos. Fotos D. Maeso 
Las manchas continúan avanzando y secan sectores de los folíolos dando lugar a otro de los síntomas característicos, que junto con los ya descritos, son responsables del nombre de la enfermedad en países de habla inglesa: "marchitamiento manchado" o "spotted wilt" (Figura 6). Generalmente los ápices de las plantas enfermas se marchitan y mueren, lo cual en poco tiempo conduce a la pérdida total de la planta. Algunos productores descopan las plantas con marchitez apical y éstas expresan síntomas fuertes de mosaico en la nueva brotación.

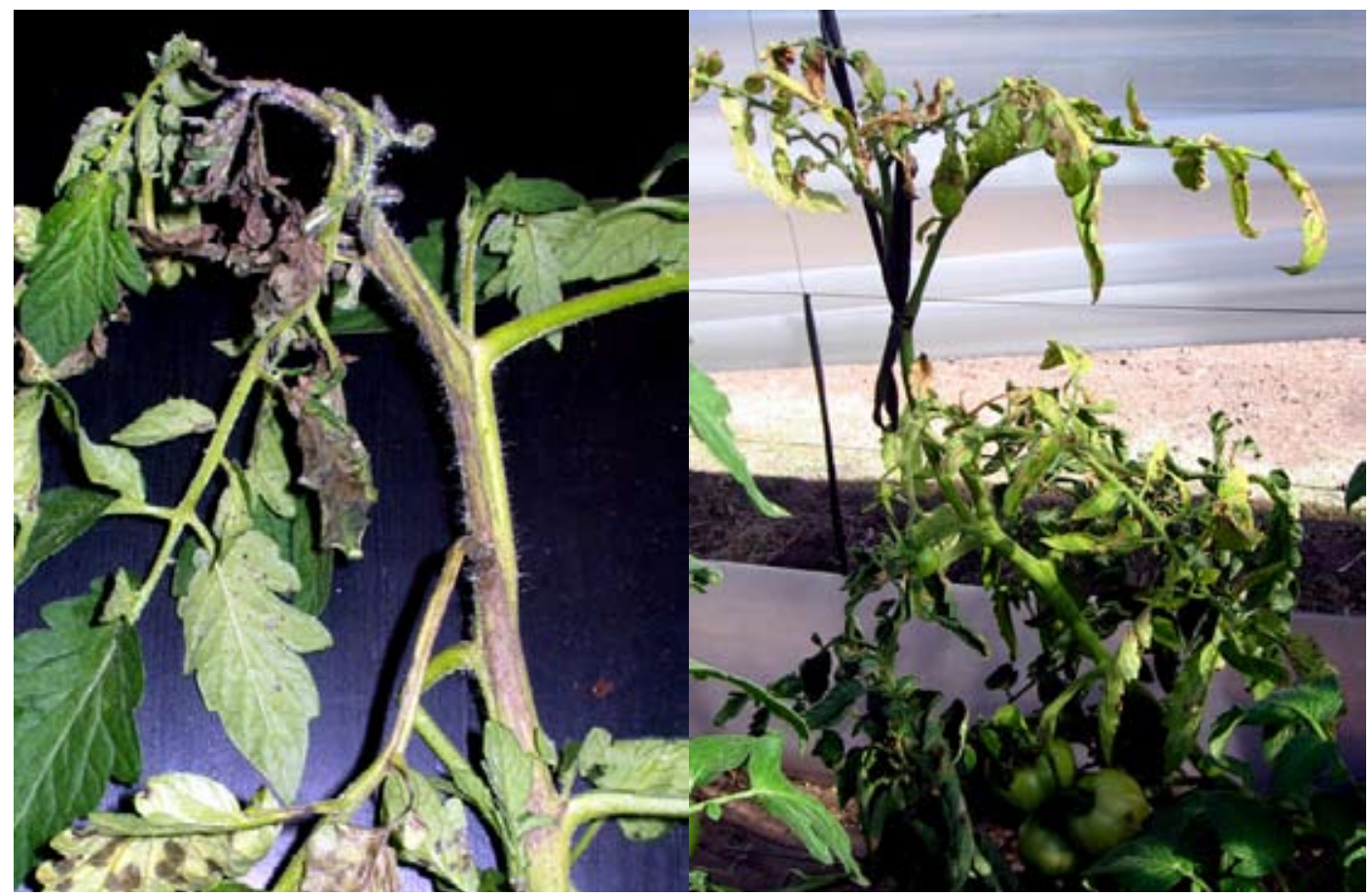

Figura 6. Marchitamiento apical en plantas enfermas de peste negra. Fotos D. Maeso.

Junto a esta sintomatología, que es la más severa, se pueden observar muchas otras menos graves. En esos casos, no se produce el marchitamiento apical o, luego de éste, la planta retoma su crecimiento con brotes laterales.

Otros síntomas son la aparición de lesiones cloróticas en las hojas en forma de anillos (Figura 7) o con dibujos diversos que luego se traducen en mosaico (Figura 8), encrespamiento (Figura 9), abultamiento y deformación (Figura 10), y epinastia o enrulado del follaje (curvado hacia abajo del pecíolo y raquis con el doblez hacia el haz de los bordes del limbo foliar, Figura 11).

Muchas veces, cuando se recorren cultivos afectados, se observan focos con plantas achaparradas fruto de infecciones puntuales asociadas a los bordes o a la cercaría con fuentes de inóculo (Figura 12).

Respecto al enrulado o epinastia de hojas, en cultivos de tomate se debe diferenciar del que normalmente aparece como respuesta de la planta al desbrotado o deshojado severo. En este caso, el desorden se presenta abruptamente luego de la labor y en gran parte de las plantas del cultivo, mientras que con peste negra al comienzo es gradual. 


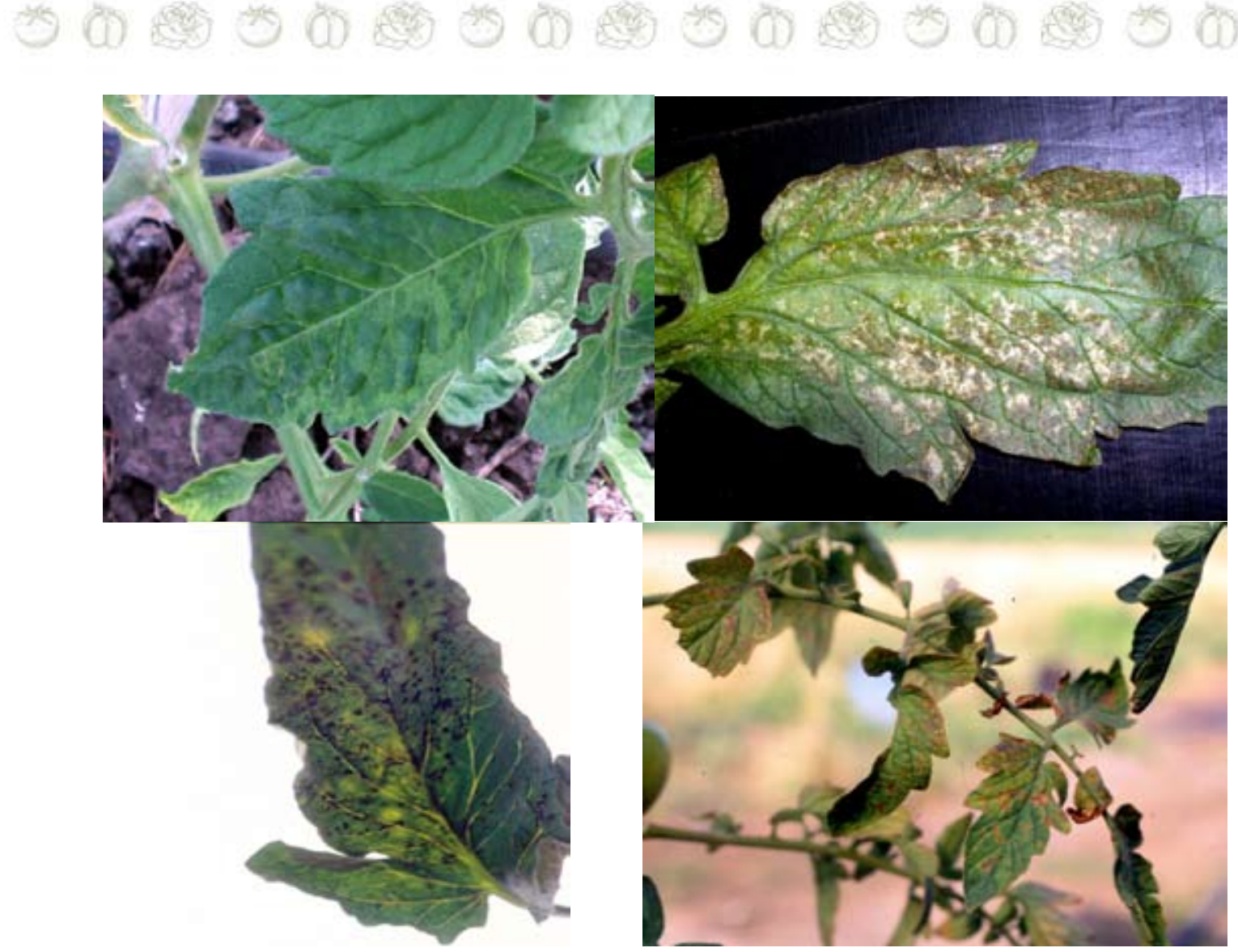

Figura 7. Anillos cloróticos en hojas de tomate. Fotos D. Maeso.

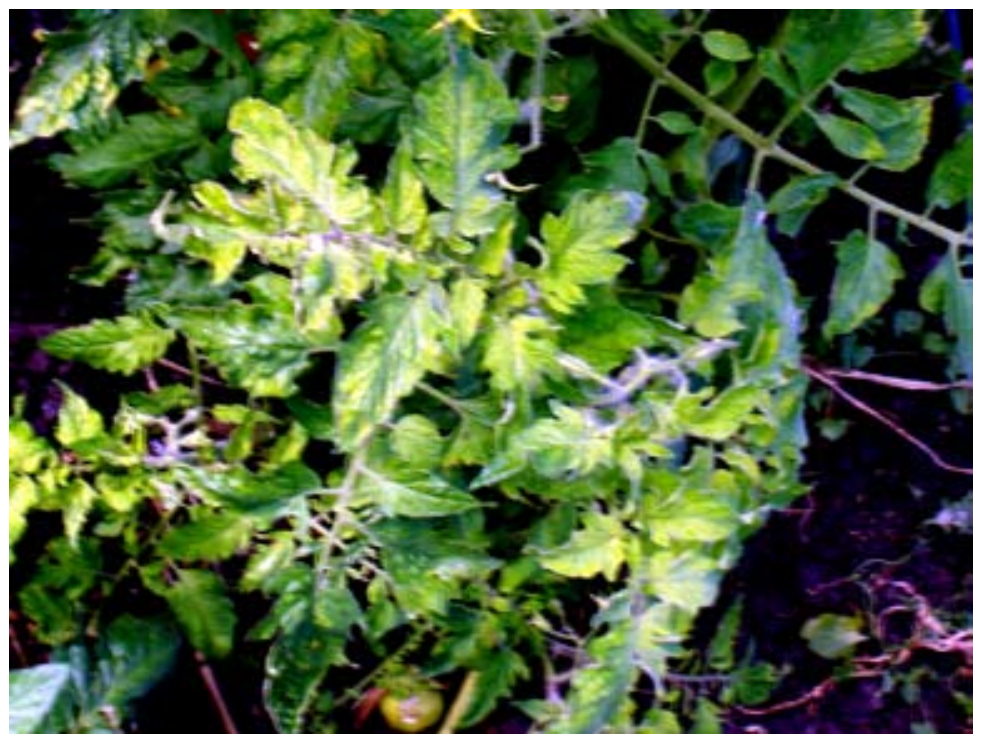

Figura 8. Mosaico foliar en plantas con peste negra. Foto D. Maeso. 


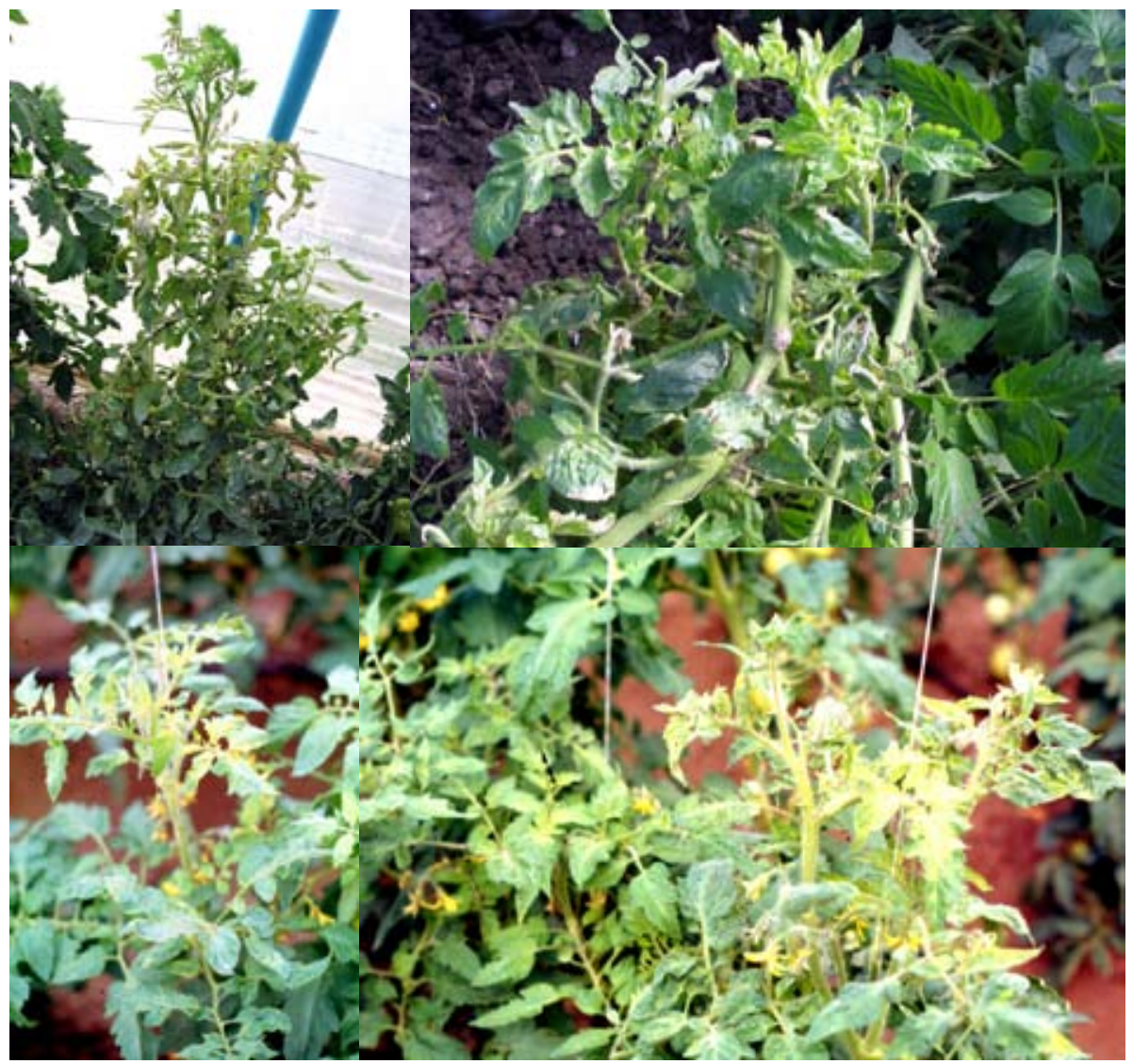

Figura 9. Encrespado de ápice en plantas de tomate provocado por peste negra. Fotos D. Maeso.

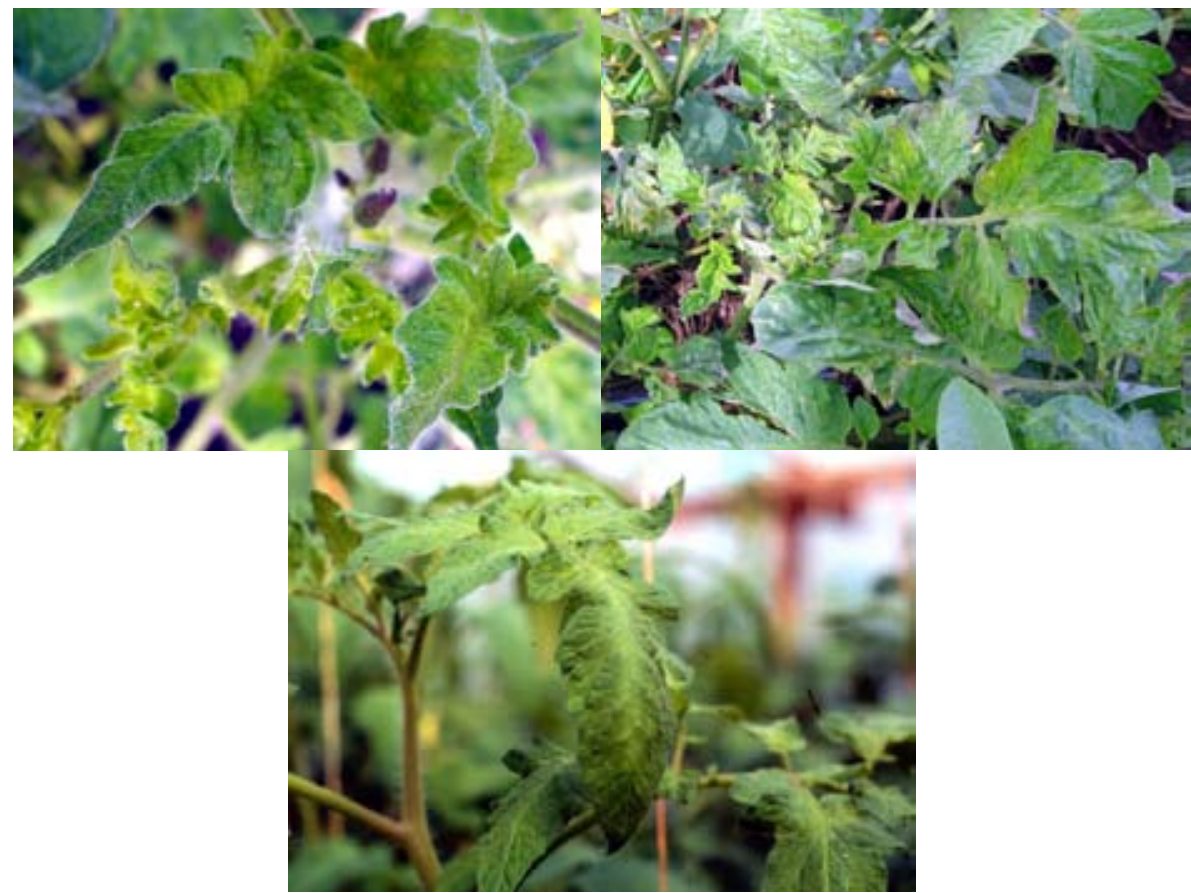

Figura 10. Abultamientos en sectores de folíolos en hojas de tomate. Fotos D. Maeso. 


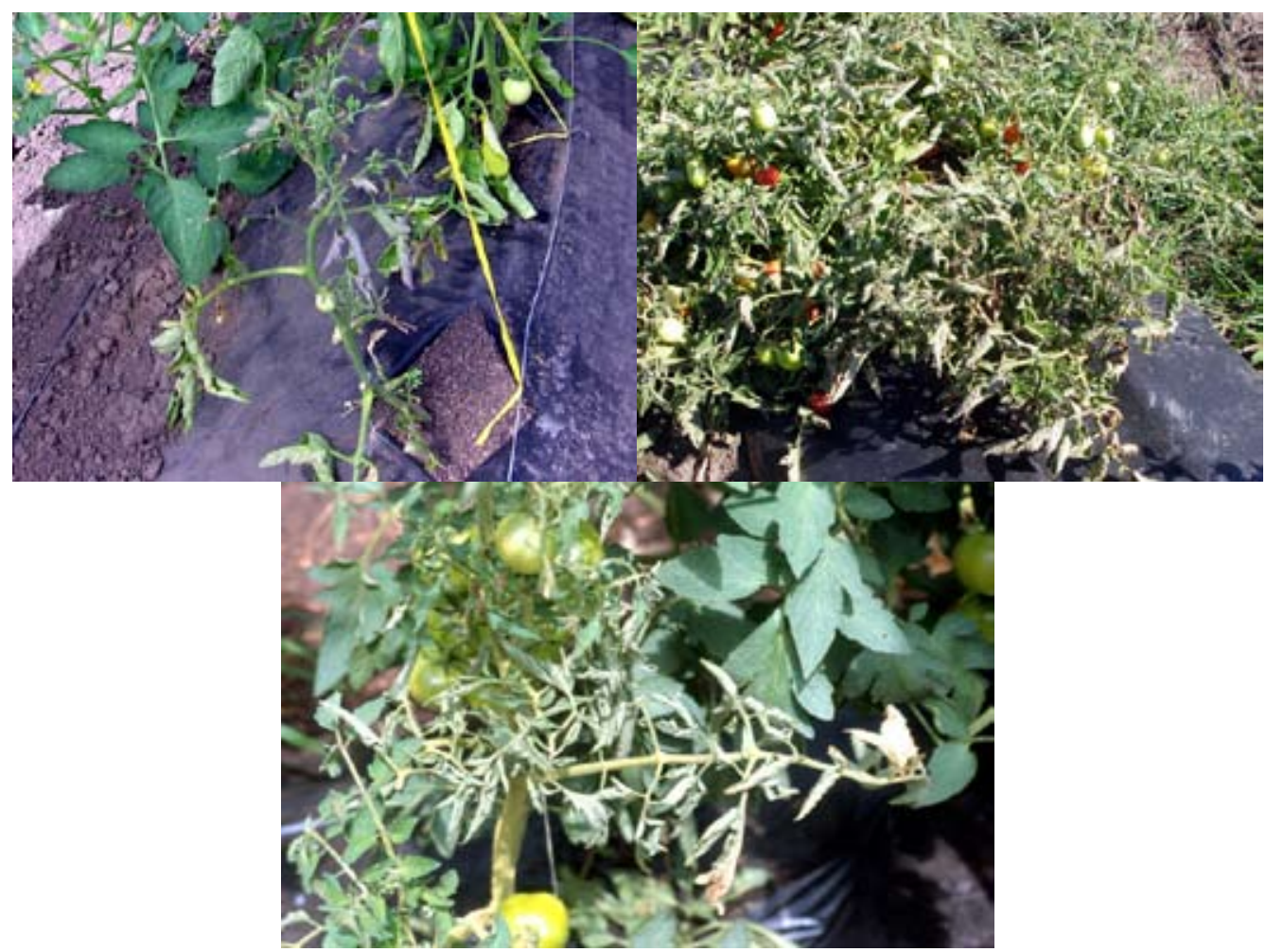

Figura 11. Epinastia y enrollado de hojas en plantas afectadas por peste negra. Fotos D. Maeso.
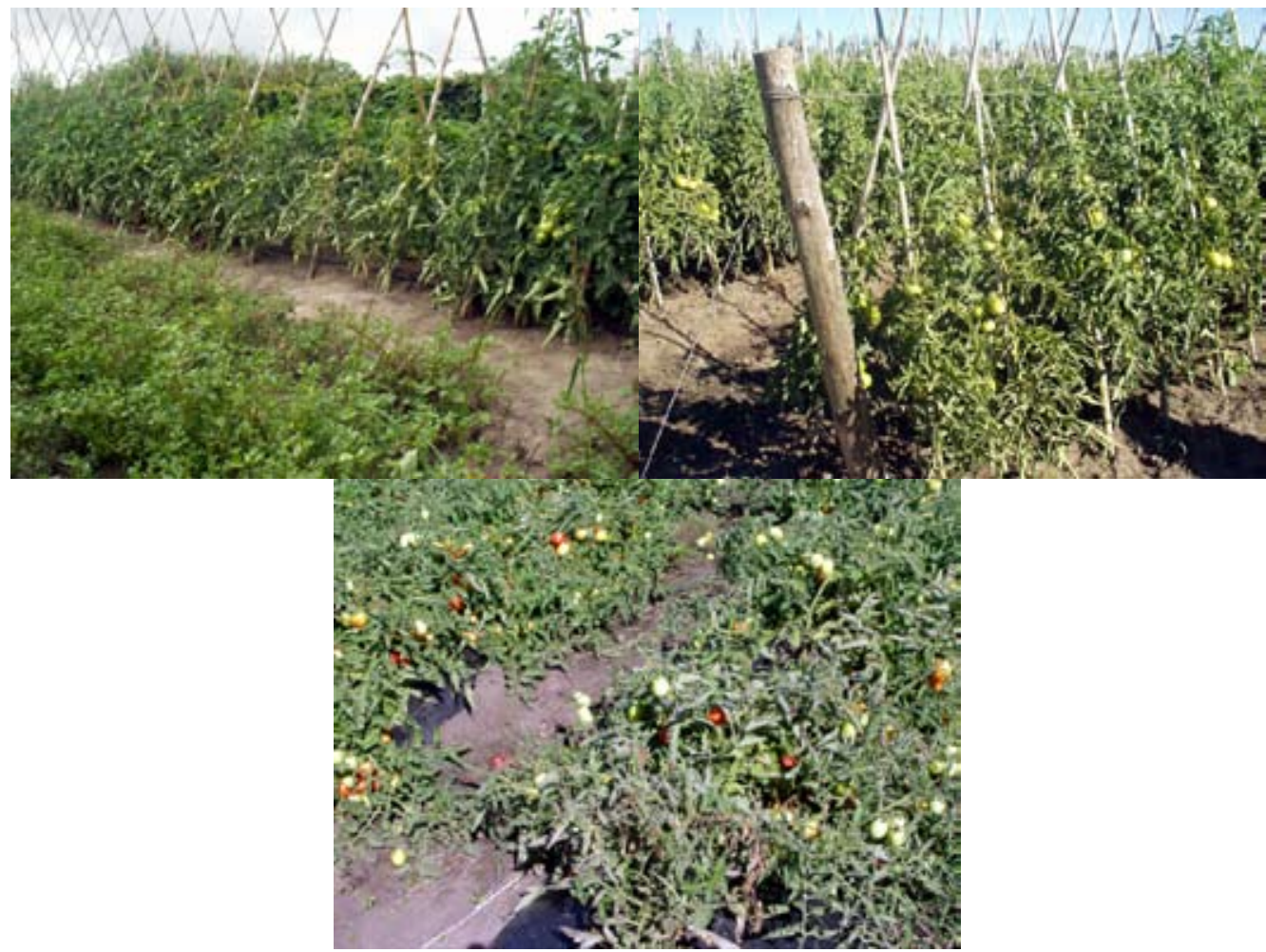

Figura 12. Plantas achaparradas en focos asociados a la cercanía con fuentes de inóculo. Fotos D. Maeso 
Cuando la planta llega a producir frutos, estos presentan coloración anormal desde los estados inmaduros (Figura 13) que, cuando van tomando coloración, desarrollan alternancia de zonas amarillas y rojas con variados dibujos, generalmente anillos (Figura 14). También se observa deformación provocada por el crecimiento desigual de las regiones afectadas y sanas (Figura 15). Los síntomas pueden aparecer en todos los frutos o solamente en algunos racimos.

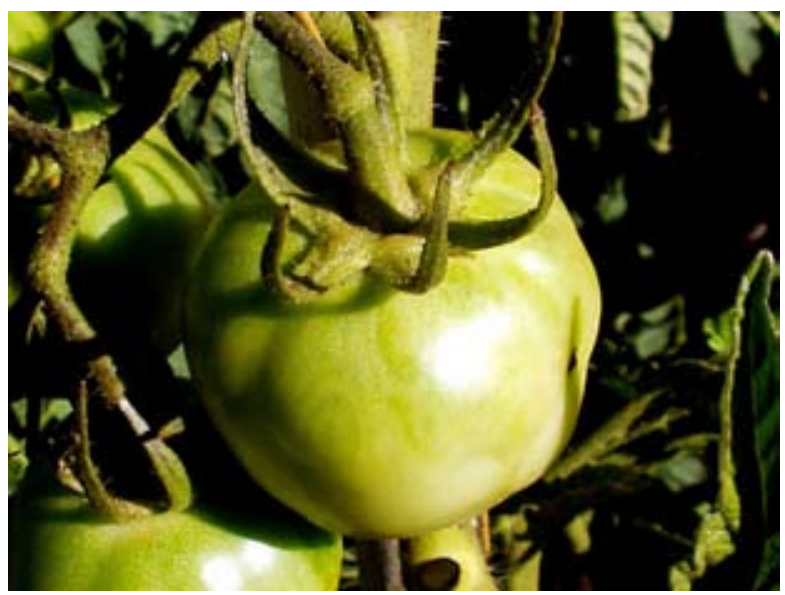

Figura 13. Presencia de manchas anilladas concéntricas de color amarillo en frutos inmaduros. Foto D. Maeso.

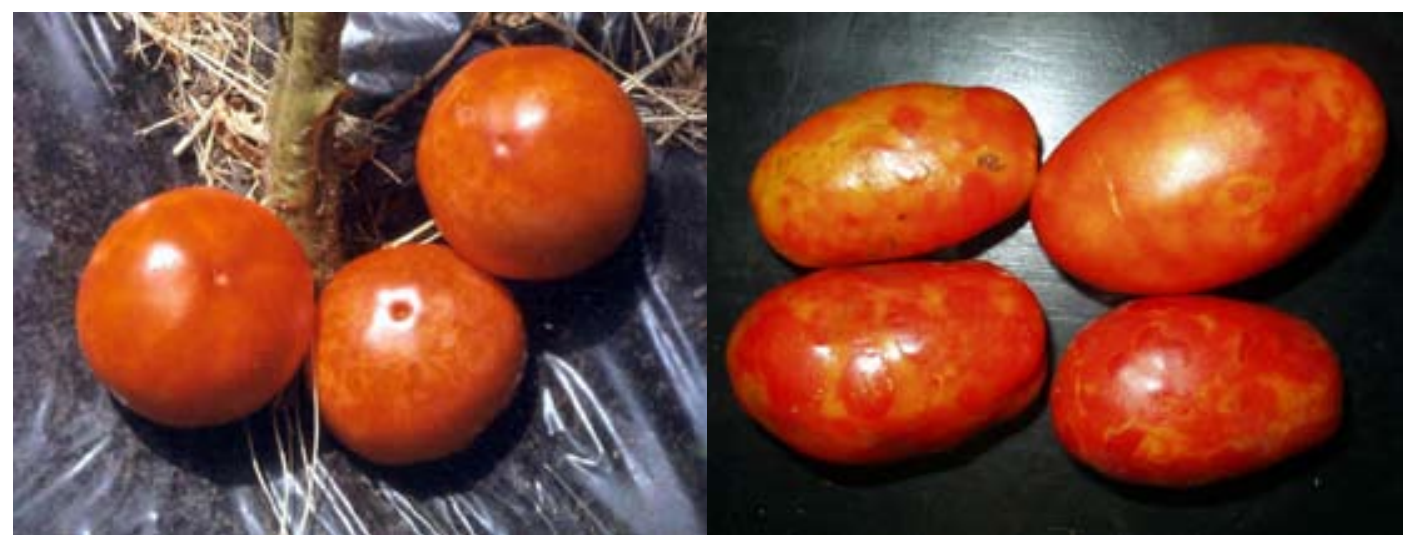

Figura 14. Manchas anilladas en frutos maduros. Fotos D. Maeso.

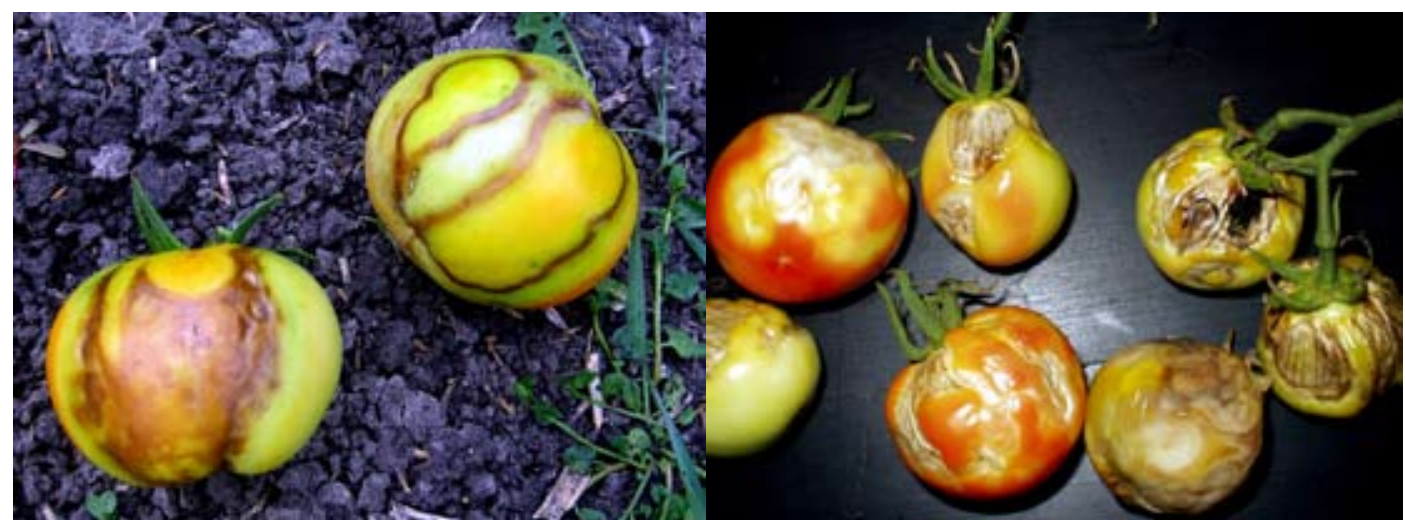

Figura 15. Deformación de frutos de tomate en plantas afectadas con peste negra. Fotos D. Maeso. 
En la Figura 16 se muestra, a modo de ejemplo, la secuencia de síntomas registrados en dos cultivos bajo invernáculo durante las temporadas 2000 y 2001. En el 2000, el cultivo estaba localizado en INIA Las Brujas, variedad Dominique, se trasplantó en octubre 1999 y en 2001 el cultivo estaba localizado en un predio en Los Arenales, Canelones, variedad Valeria y se trasplantó en setiembre 2000 (Figura 17).

Como se puede observar, existe una secuencia de síntomas de acuerdo con el momento en que se registró la infección. Los síntomas iniciales correspondieron a manchas, dibujos y cambios de color en el verde natural de la hoja (anillos, mosaicos, moteados cloróticos), luego se produjo la muerte de tejido con manchas necróticas y estrías en hojas y tallos, acompañados con alteraciones en el crecimiento y el desarrollo de la planta lenanismo, achaparramiento, encrespamiento de follaje), cambios en el color del follaje lapariencia bronceada-violáceal y finalmente, se produce el marchitamiento del ápice seguido por la muerte de la planta. Como se puede observar, las plantas infectadas sobre el fin de ciclo produjeron manchas en frutos.
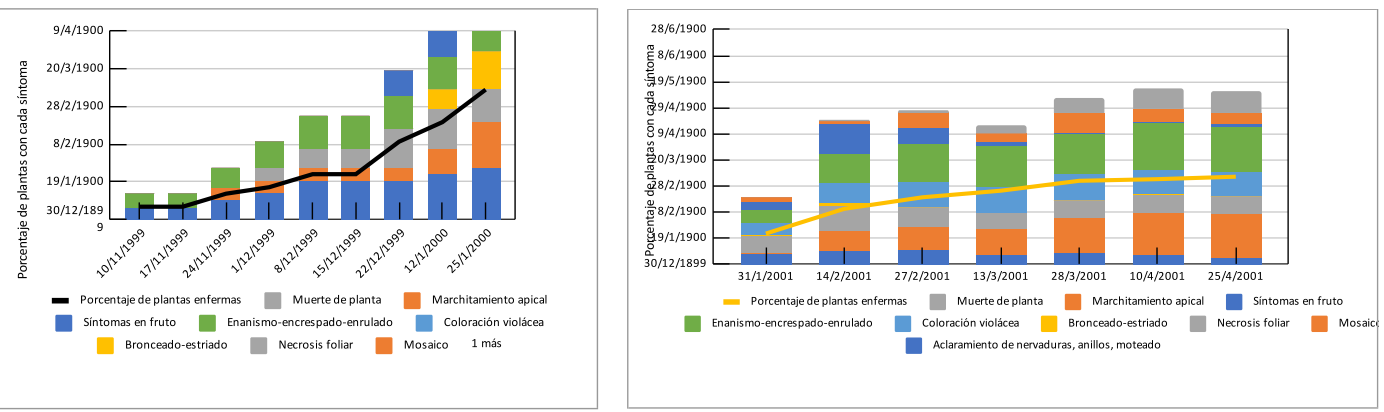

Figura 16. Evolución de síntomas en cultivos afectados con peste negra ltodas las plantas incluidas en los estudios fueron positivas en pruebas serológicas de laboratorio). Se muestra la evolución total de la incidencia y el porcentaje de plantas que presentaba cada síntoma. Izquierda: Cultivar Dominique, INIA LB, 1999-2000 (n=30); derecha: cultivar Valeria, Arenales, 2000-2001 (n=158).

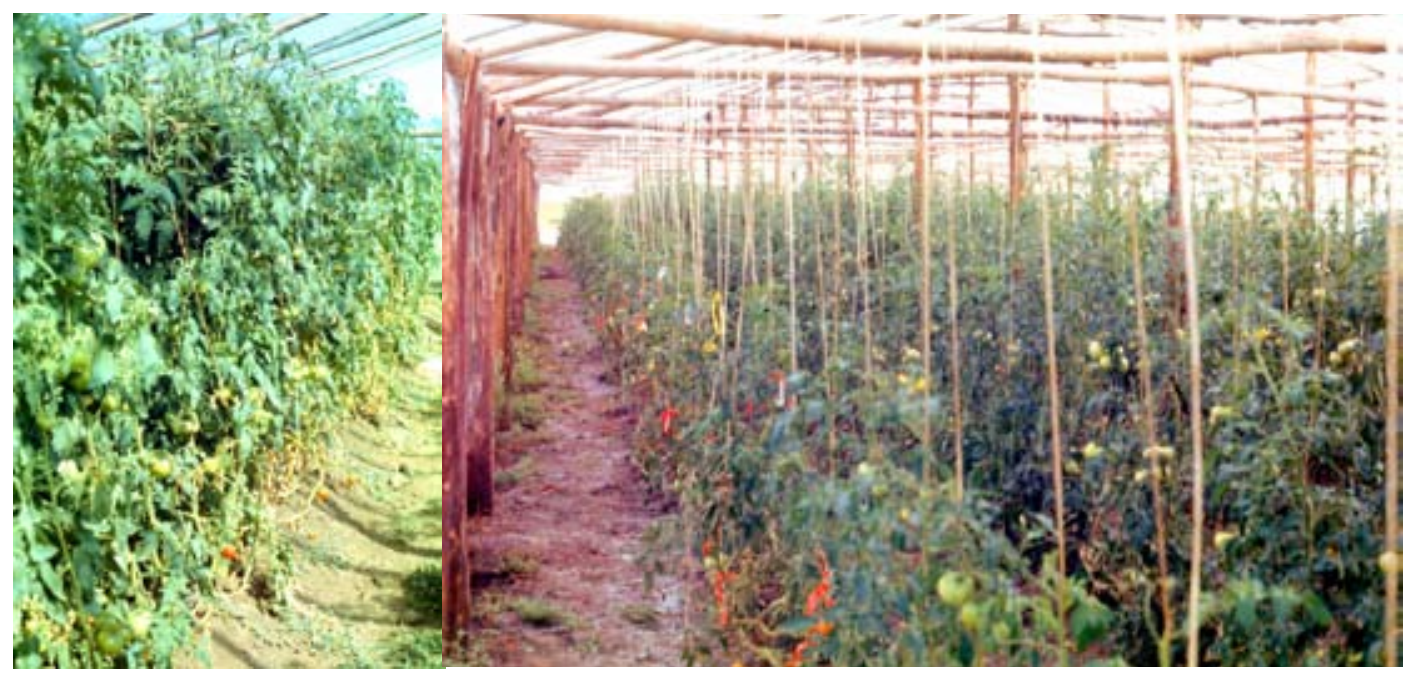

Figura 17. Vista general de los cultivos en los que se realizaron los registros de evolución de síntomas. Izquierda invernáculo en INIA Las Brujas y derecha invernáculo comercial en Arenales, (departamento de Canelones). 


\section{Morrón}

Los síntomas en morrón si bien conservan algunas similitudes con los presentados para tomate presentan importantes diferencias. La principal es que, si bien se produce el típico marchitamiento apical, las manchas necróticas y la deformación foliar, existe un predominio de coloraciones foliares amarillentas en forma de anillos, líneas, etc. de forma tal que algunos productores especializados en morrón se preguntan por qué no llamar "peste amarilla" a esta enfermedad.

Como ya se mencionó, también en morrón, el tipo, intensidad y evolución de síntomas dependen de la edad de la planta a la que se produjo la infección, las condiciones ambientales y la presión de reinfección a la que se vio sometido el cultivo. Cuando la infección se produjo durante el almácigo o en los primeros días después del trasplante, las plantas se vuelcan mostrando un marchitamiento incipiente del brote que luego se necrosa (Figura 18). Esos plantines pueden marchitarse completamente y morir 0 , continuar desarrollándose, pero con diversas alteraciones y síntomas foliares severos (Figura 19). Las plantas infectadas desarrollan mosaicos y diferentes dibujos de coloración amarilla, retrasan su crecimiento, presentan acortamiento de entrenudos, necrosis de nervaduras o manchas necróticas, deformación de hojas y brotes y muerte de tejidos (Figuras 20 y 21).

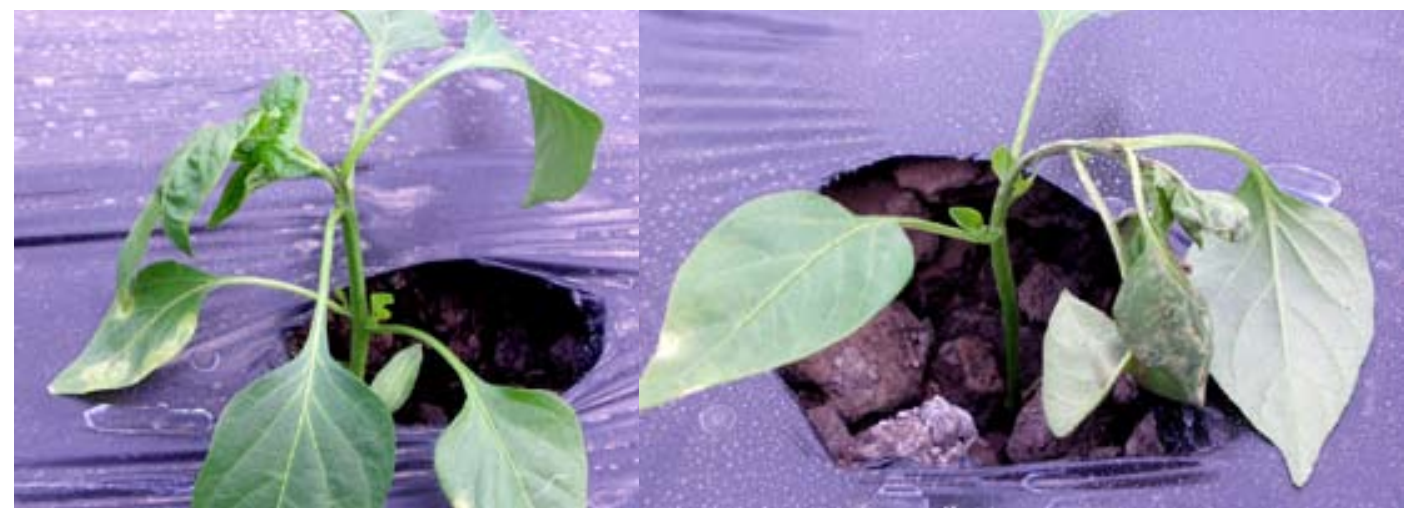

Figura 18. Síntomas de peste negra en plantines de morrón en las primeras etapas pos-trasplante (nótese la presencia de anillos cloróticos en las primeras hojas). Fotos D. Maeso.

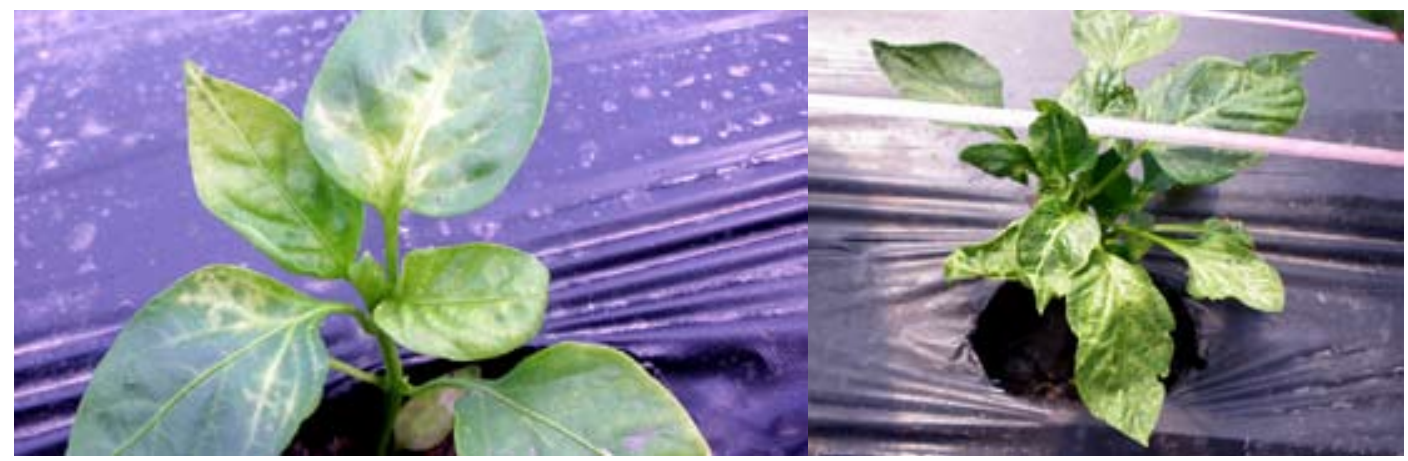

Figura 19. Enanismo, deformación foliar y dibujos cloróticos en plantines de morrón en las primeras etapas pos-trasplante. Fotos D. Maeso. 


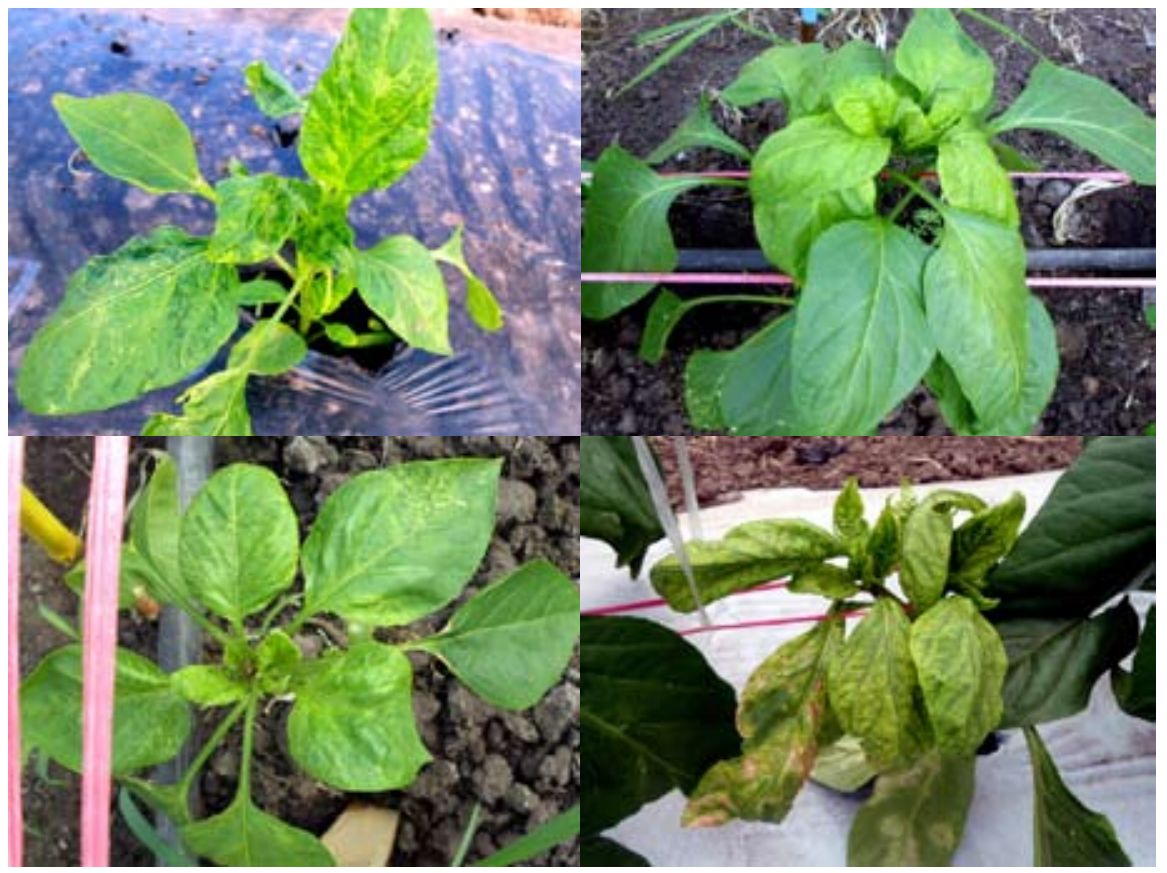

Figura 20. Síntomas de peste negra en plantines de morrón, deformación y coloración anormal de hojas y detención del crecimiento. Fotos D. Maeso.

Las plantas infectadas en etapas posteriores también detienen su crecimiento y hay muerte de los brotes apicales (Figura 22). Se observan diversos dibujos en las hojas (Figura 23) predominando la coloración amarilla (mosaicos, anillos, líneas), que luego se aclara, pierde brillo y, finalmente el tejido se necrosa y seca (Figura 24). Esta coloración generalmente es acompañada por la deformación severa de la lámina y diferencias en su relieve (Figura 25).

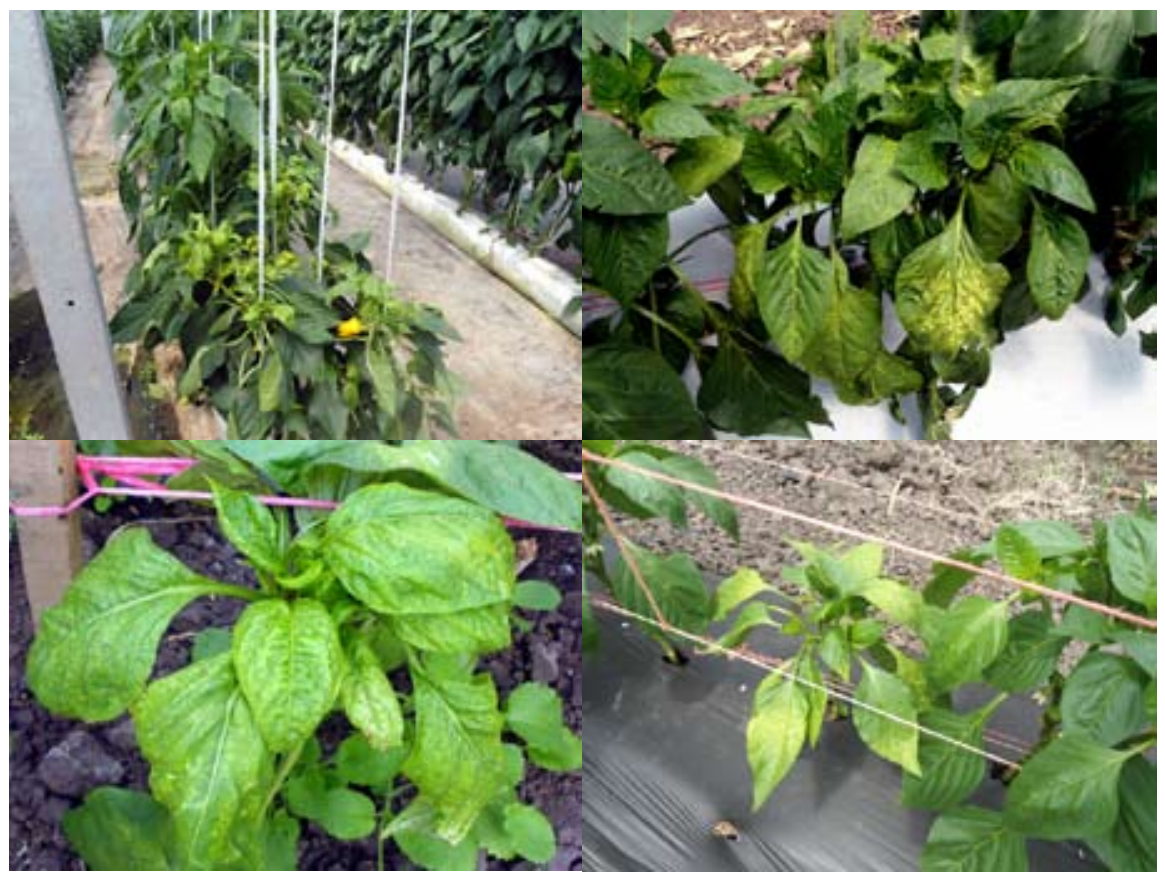

Figura 21. Enanismo y crecimiento anormal de plantas afectadas por peste negra. Fotos D. Maeso. 


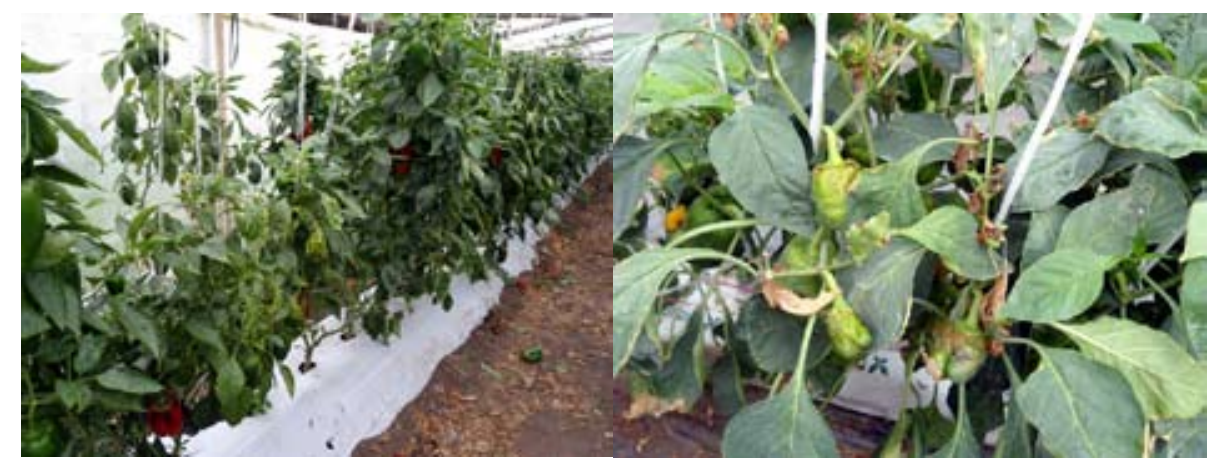

Figura 22. Detención de crecimiento, enanismo y muerte de brotes en plantas de morrón con peste negra. Fotos D. Maeso.

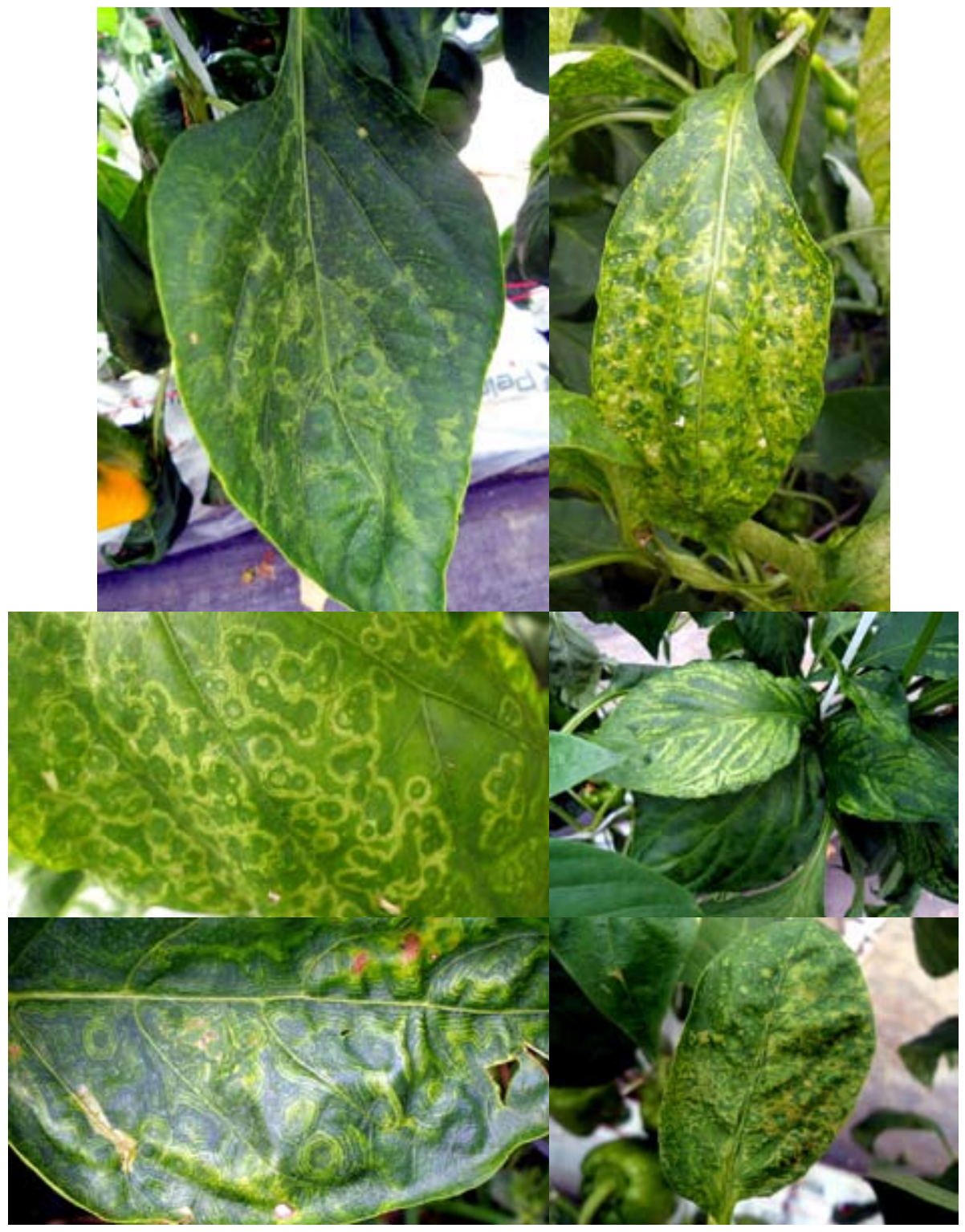

Figura 23. Dibujos de coloración amarilla en hojas de plantas de morrón con peste negra. Fotos D. Maeso. 


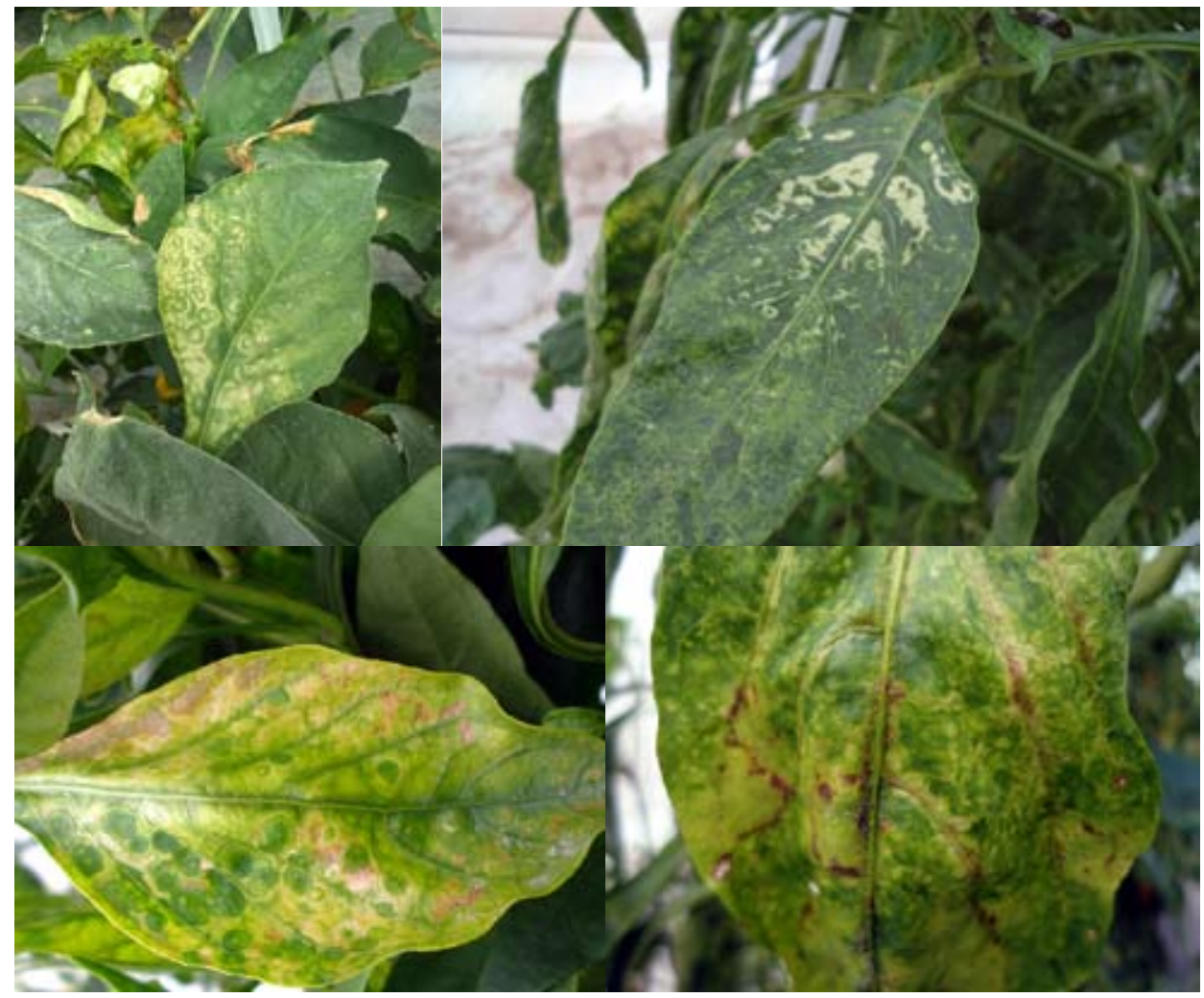

Figura 24. Coloración amarilla atenuada y necrosis de tejidos en hojas que previamente presentaban mosaicos y dibujos. Fotos D. Maeso.

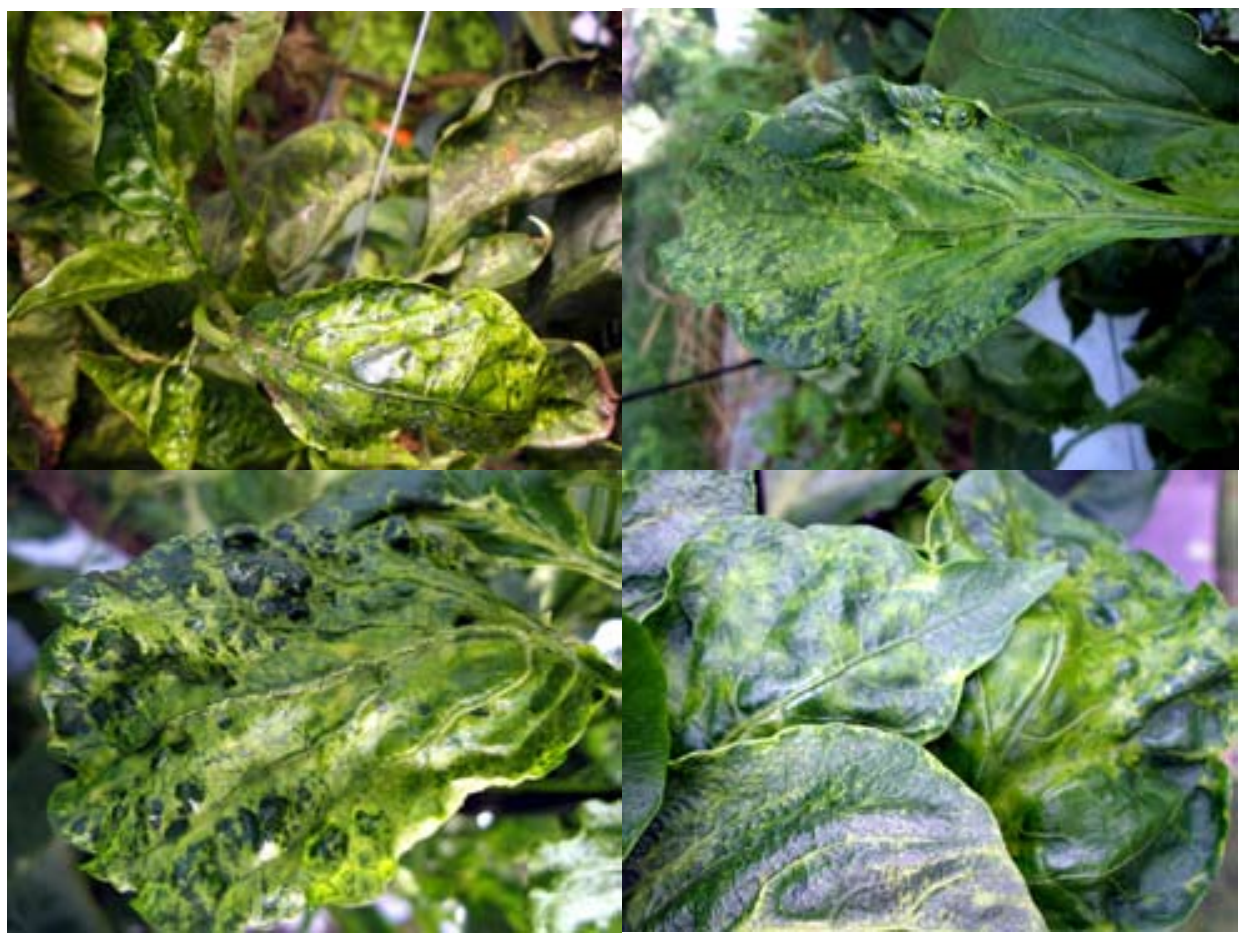

Figura 25. Deformación foliar acompañada de mosaicos y coloraciones amarillentas. Fotos D. Maeso. 
Si la enfermedad avanza, las hojas y los brotes de las plantas enfermas pueden secarse y morir, pero, si continúan su crecimiento, éste es anormal permaneciendo enanas, con entrenudos cortos, hojas enrolladas, deformadas y con muerte de brotes (Figura 26).

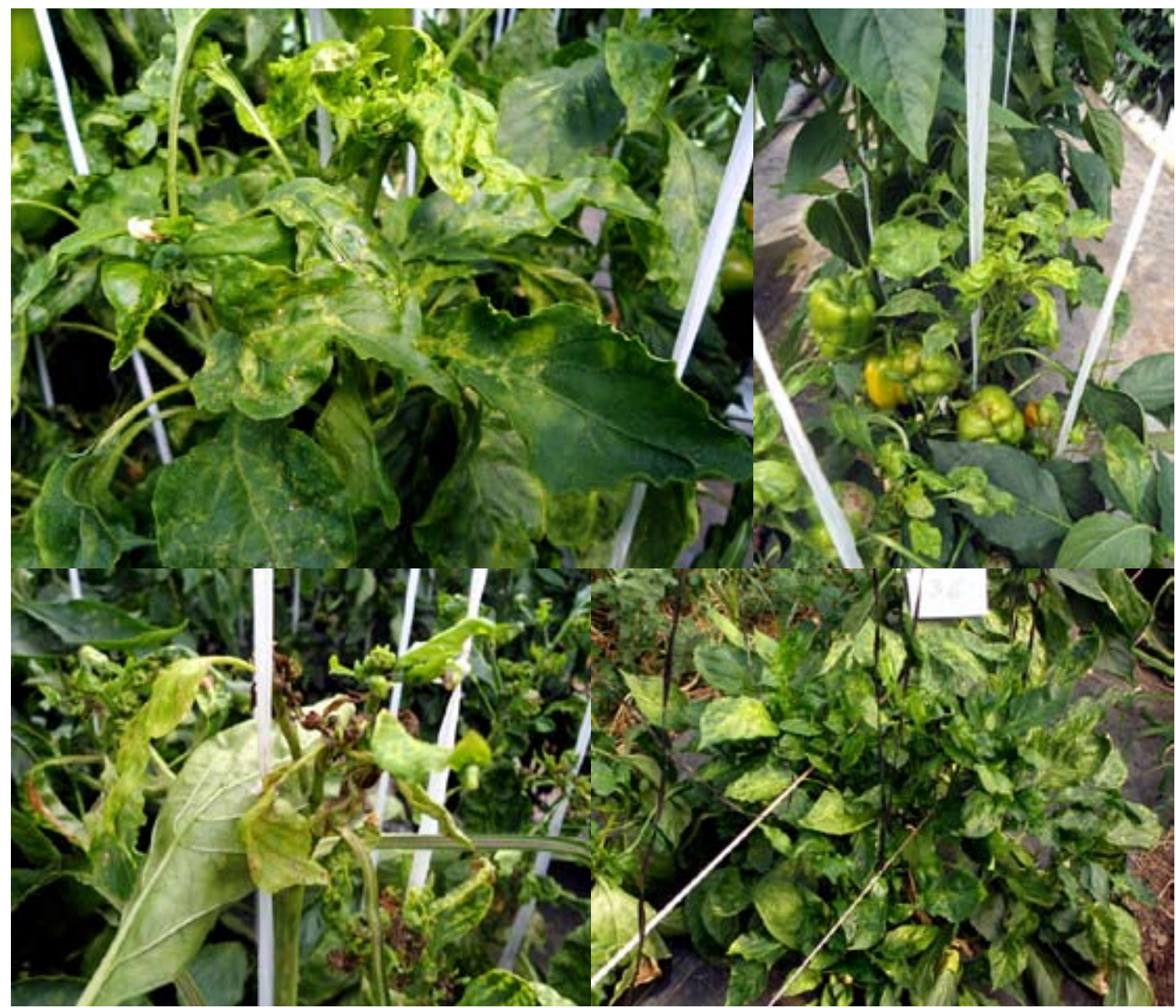

Figura 26. Enanismo, crecimiento distorsionado, deformación foliar y muerte de brotes. Fotos D. Maeso.

Los síntomas en frutos son variables y dependen de la etapa de su desarrollo en la que se registró la infección y del estado general de la planta. Si la infección fue en un estadio temprano, los frutos se deforman, presentan áreas necrosadas con diferente coloración y relieve (Figura 27) y pueden secarse totalmente (Figura 28). 


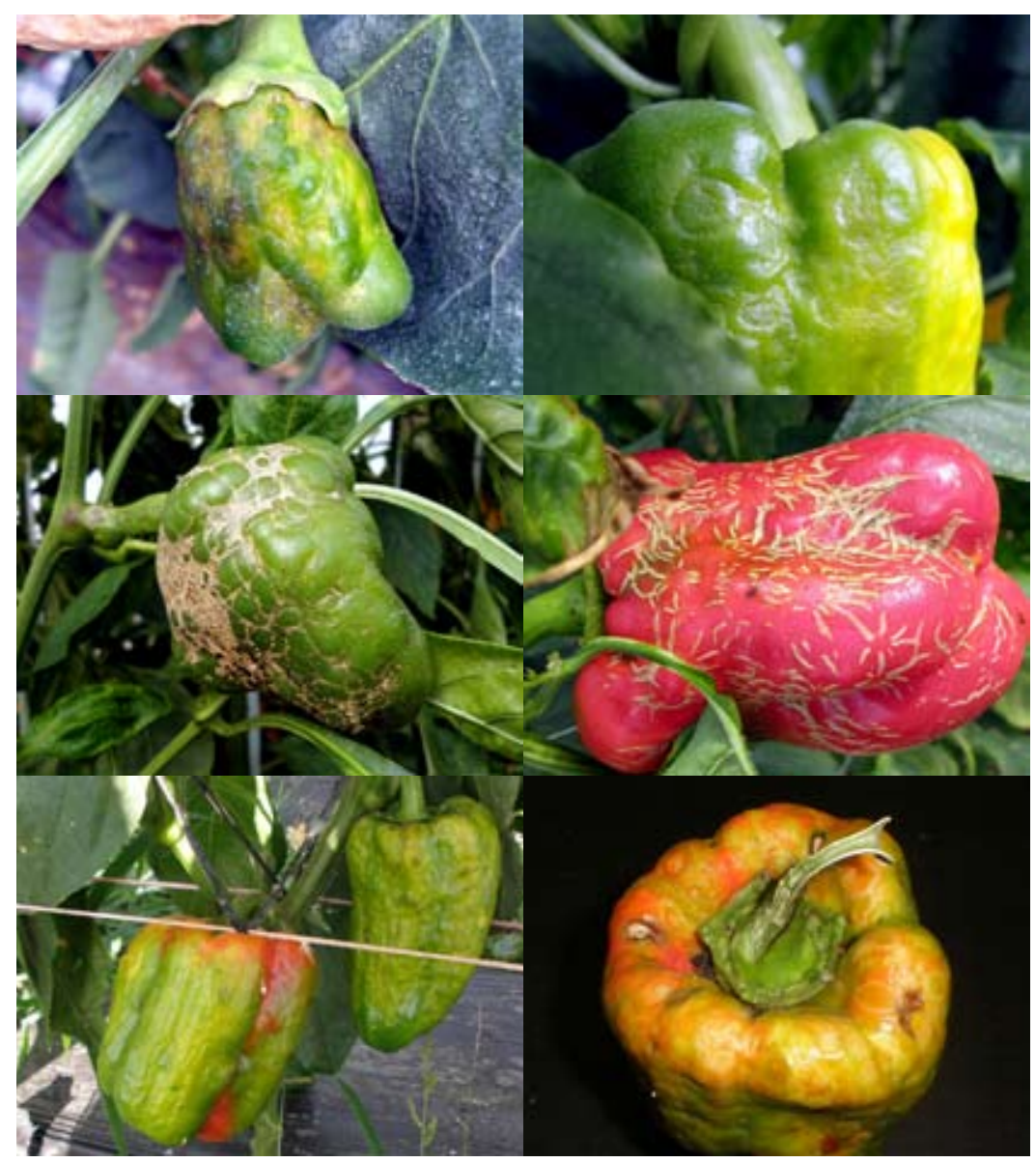

Figura 27. Deformación y necrosis de frutos de morrón provocada por peste negra. Fotos D. Maeso.

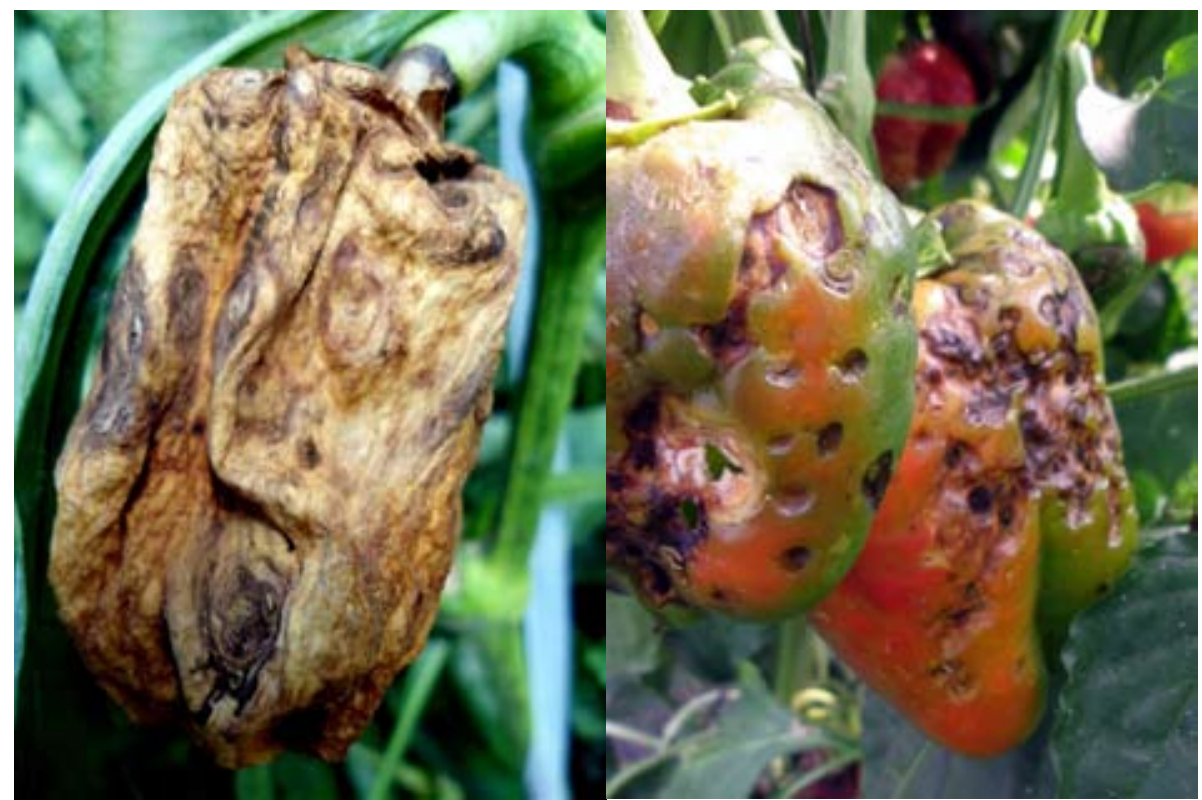

Figura 28. Necrosis de frutos de morrón provocada por peste negra. Fotos D. Maeso. 
Cuando los ataques son tardíos, al igual que ocurre en tomate, la deformación no es tan pronunciada, pero sí se altera la coloración presentando anillos y zonas amarillentas y verdes junto a la coloración normal a la madurez (Figura 29).

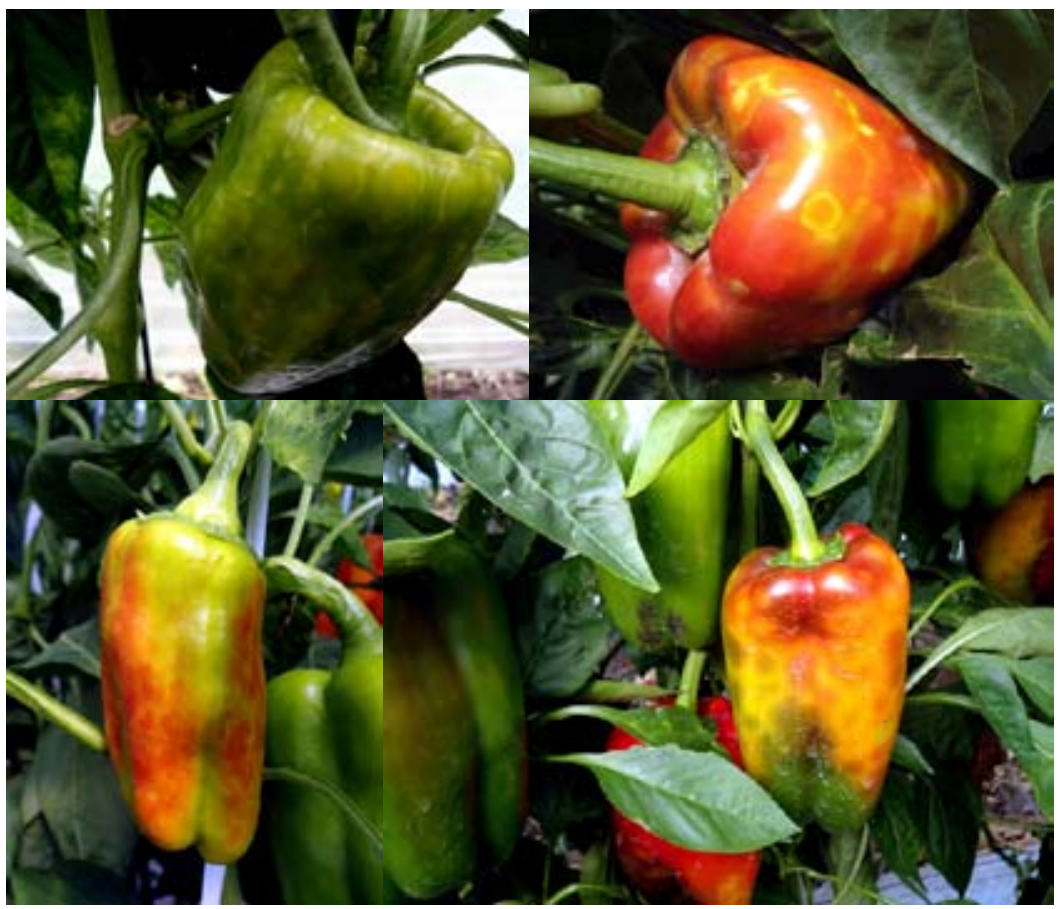

Figura 29. Coloración irregular en frutos de morrón en plantas infectadas tardíamente con peste negra. Fotos D. Maeso.

En algunas temporadas o momentos del año en que la oferta de morrón rojo es escasa y la distorsión en la coloración no es tan intensa y los ataques han sido generales en el cultivo, estos frutos pueden llegar a ser comercializados (Figura 30).

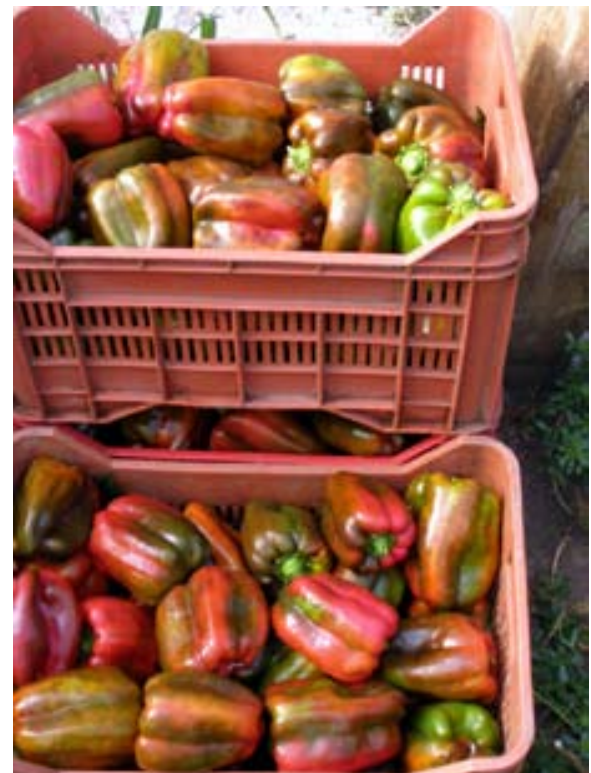

Figura 30. Frutos con coloración irregular por ataques tardíos de peste negra cosechados para su comercialización. 



\section{ORGANISMOS CAUSALES}

Como ya se mencionó, en 1930 se reconoció la naturaleza viral de esta enfermedad y se denominó a su agente causal como Tomato spotted wilt virus (TSWV), en referencia a los síntomas característicos que producía en el primer huésped donde fue determinado. Taxonómicamente se creó el grupo “Tomato spotted wilt” para incluirlo (le, 1970; Mathews, 1982). Estudios posteriores ameritaron su inclusión en la familia Bunyaviridae, dentro de la cual es el único grupo que infecta vegetales (Milne y Francki, 1984; Kormelink et al., 1991). Por esa razón se piensa que inicialmente se trataba de un virus de vertebrados (como muchos de los integrantes de la familia) que pasó a infectar a trips y luego, debido a la interacción de esos insectos con las flores de sus huéspedes vegetales, se adaptaron a ellos (Kormelink et al., 1991).

A partir de 1990 se fueron describiendo virus similares a TSWV, comenzando con Impatiens necrotic spot virus (INSV) (Law y Moyer, 1990; Law et al., 1991; 1992; de Ávila et al., 1992), pero con diferencias, serológicas, en rango de hospederos y moleculares (Moyer, 1999; Adam et al., 1993; de Ávila et al., 1993).

En un principio, TSWV fue separado en dos razas: TSWV-L (de lechuga, el "tradicional") y TSWV-I ("Impatiens"). Luego se describieron cuatro serogrupos (I-IV), utilizando antisueros policlonales para las proteínas de la membrana y nucleoproteínas y, en al menos seis serotipos según reacción con antisueros monoclonales (de Ávila et al., 1990; 1993; Adam et al., 1993; Feldhoff et al., 1997). En el serogrupo I se incluyeron los aislados de TSWV propiamente dicho, en el II algunos de los aislados que luego se denominaron TCSV y GRSV (serotipos dentro del grupo II), en el III a INSV y en el IV a Watermelon silver mottle virus (WSMoV) y otros aislados provenientes de Asia.

Posteriormente se creó el género Tospovirus con TSWV como miembro tipo (Francki et al., 1991; Prins y Goldbach, 1998) en el cual se agruparon a todas las especies descritas, entre ellas Groundnut ringspot virus (GRSV) y Tomato chlorotic spot virus (TCSV) reportadas también en tomate y pimiento. La diferenciación entre especies en el género Tospovirus se realizó principalmente por serología y la secuencia del gen N (de Ávila et al., 1990; 1992; 1993; Pappu et al., 1998).

A partir de 2016 se introdujeron cambios en la taxonomía, TSWV pasó a llamarse Tomato spotted wilt orthotospovirus y el género Orthotospovirus, que fue incluido en la familia Tospoviridae, orden Bunyavirales. (Adams et al., 2017; Maes et al., 2019; Resende y Pappu, 2020; https://talk.ictvonline.org/ictv-reports/ictv_online_report/).

El International Committee for the Taxonomy of Virus (ICTV) ha aceptado hasta el momento a once miembros en el género y 29 especies aparecen como tentativas (Turina et al., 2016; Fermin, 2018; ICTV, 2019; Resende y Pappu, 2020).

En el cuadro 1 se muestra la lista de especies de Orthotospovirus, país de denuncia y probable región de origen según el análisis filogenético de Turina et al. (2016) según el cual existirían tres "linajes" (americano, euroasiático y asiático), muy vinculados con las especies de insectos vectores (Jones, 2005, Pappu et al 2009, Inoue y Sakurai, 2007; Tentchev et 
al., 2011) y los serogrupos (TSWV, WSMoV y IYSV) a los que pertenecen. TSWV, GRSV y TCSV se destacan como causantes de enfermedades en tomate y morrón en nuestra región y existirían algunos nuevos orthotospovirus como amenaza para estos cultivos. Luego de Asia, Sudamérica es el continente que presenta la mayor diversidad de orthotospovirus (de Ávila et al., 1993; Bezerra et al.,1999).

Cuadro 1. Lista de especies de orthotospovirus reportados y su origen geográfico ladaptada de Turina et al., 2016; Pappu et al., 2009) ${ }^{1}$

\begin{tabular}{|c|c|c|c|}
\hline Acrónimo & Nombre del virus & País de reporte & $\begin{array}{l}\text { Origen geográfico } \\
\text { según análisis } \\
\text { filogenético }\end{array}$ \\
\hline ANSV & Alstroemeria necrotic streak virus & Colombia & América \\
\hline BeNMV & Bean necrotic mosaic virus & Brasil & América \\
\hline $\mathrm{CaCV}$ & Capsicum chlorosis virus & Australia & Asia \\
\hline CCSV & Calla lily chlorotic spot virus & Taiwan & Asia \\
\hline CSNV & Chrysanthemum stem necrosis virus & Brasil & América \\
\hline GBNV & Groundnut bud necrosis virus & India & Asia \\
\hline GRSV & Groundnut ringspot virus & Brasil & América \\
\hline GYSV & Groundnut yellow spot virus & India & Asia \\
\hline HCRV & Hippeastrum chlorotic ringspot virus & China & Europa/Asia \\
\hline INSV & Impatiens necrotic spot virus & Estado Unidos & América \\
\hline IYSV & Iris yellow spot virus & $\begin{array}{c}\text { Israel, Estados } \\
\text { Unidos, Brasil, } \\
\text { Holanda }\end{array}$ & Europa/Asia \\
\hline LNRV & Lisianthus necrotic ringspot virus & Japón & Asia \\
\hline MSMV & Melon severe mosaic virus & Méjico & América \\
\hline MVBaV & Mulberry vein banding associated virus & China & Asia \\
\hline MYSV & Melon yellow spot virus & Japón & Asia \\
\hline PCFSV & Peanut chlorotic fan-spot virus & Taiwan & Asia \\
\hline PCSV & Pepper chlorotic spot virus & Taiwan & Asia \\
\hline PNSV & Pepper necrotic spot virus & Perú & América \\
\hline PolRSV & Polygonum ringspot virus & Italia & Europa/Asia \\
\hline SVNaV & Soybean vein necrosis-associated virus & Estados Unidos & América \\
\hline TCSV & Tomato chlorotic spot virus & Brasil & América \\
\hline TNRV & Tomato necrotic ringspot virus & Tailandia & Asia \\
\hline TNSV & Tomato necrotic spot virus & China & Asia \\
\hline TSWV & Tomato spotted wilt virus & Australia & América \\
\hline TYRV & Tomato yellow ring virus & Irán & Europa/Asia \\
\hline TZSV & Tomato zonate spot virus & China & Asia \\
\hline WBNV & Watermelon bud necrosis virus & India & Asia \\
\hline WSMoV & Watermelon silver mottle virus & Taiwan & Asia \\
\hline ZLCV & Zucchini lethal chlorosis virus & Brasil & América \\
\hline
\end{tabular}

${ }^{1}$ Los nombres en cursiva son las especies reconocidas por ICVT. En negrita se destacan las especies reportadas atacando tomate y morrón en nuestra región. 
Actualmente la diferenciación entre especies se realiza por la estructura y organización del genoma, la secuencia de sus genes $\mathrm{N}$ y propiedades biológicas, tales como la transmisión por vectores y el rango de huéspedes (Goldbach y Kuo, 1996; Qiu et al., 1998). La secuencia de aminoácidos de la proteína $\mathrm{N}$ es considerada como el principal descriptor de nuevas especies y para clasificar los grupos geográficos, estableciéndose el límite en $90 \%$ de identidad (de Ávila et al., 1993; Pappu et al., 1998; de Breuil et al., 2016).

TSWV se presenta en las plantas infectadas como una mezcla heterogénea de aislados que se ha desarrollado naturalmente por recombinación, deriva genética al azar y mutación. Esos aislados son distinguibles únicamente por los síntomas que provocan y le permiten a este virus adaptarse a nuevos hospederos mediante reordenamiento de los segmentos del genoma ("virus reassortment") e intercambio de información genética entre los componentes de esa mezcla. Este fenómeno ocurre principalmente con virus que poseen genomas divididos y alta tasa de mutación y es provocada por la poca capacidad de corrección de su replicasa (Moyer, 1999). Este fenómeno es consistente con la primera separación de cepas según síntomas y además explica la presencia, en plantas infectadas, de "moléculas de ARN defectivas interferentes" (DIs), que originan partículas sin capacidad infectiva, un fenómeno conocido desde hace décadas (le, 1982; Verkleij y Peters, 1983; Resende et al. 1991; Nagata et al., 2000).

Vinculado con lo anterior, se comprobó que algunas de las nuevas especies, corresponden a eventos naturales de reordenamiento, en los que, virus muy relacionados intercambian información genética aumentando su diversidad (Qiu et al., 1998; Martínez et al., 2019) y formaría parte de una adaptación evolutiva a huéspedes, vectores y zonas geográficas (Tsompana et al., 2005; Tentchev et al., 2011). Eso explicaría por qué el genoma de algunos aislados de TCSV está compuesto por los segmentos $L$ y $S$ de GRSV y uno M propio, que a su vez tiene alta homología con el correspondiente de GRSV (Qiu et al., 1998; Webster et al., 2011; 2015; de Breuil et al., 2016). Este fenómeno es favorecido por la existencia de infecciones mixtas de especies en algunas regiones (Webster et al., 2015).

\section{Características de las partículas de Orthotospovirus}

Las partículas de los orthotospovirus son casi esféricas de 80-120 nm de diámetro (Figura 32) y poseen características muy diferentes al resto de virus que atacan vegetales. Su genoma es de lectura negativa y ambisentido y está formado por tres segmentos de ARN de cadena simple denominados $L, M, S$ según su tamaño (grande, mediano y pequeño) que codifican seis proteínas. Los viriones están recubiertos por una membrana lipídica proveniente del huésped, con proyecciones glicoproteicas de dos tipos (GN y GC) codificadas por el virus. En su interior se encuentran varias copias de una ARN polimerasa dependiente de ARN (RdRp) y ribo nucleoproteínas complejas (RNPs) formadas por los segmentos de ARN encapsidados en nucleoproteínas de la cápside ( $N$ ) que forman una estructura circular (Figura 33). 
El ARN L es de polaridad negativa ( $~ 8.9 \mathrm{~kb})$ y codifica la polimerasa viral (RdRp). El M ( 4.8 kb) tiene un arreglo ambisentido, codifica en sentido positivo a la proteína no estructural $\left(N_{\mathrm{m}}\right)$, imprescindible para el movimiento célula a célula en la planta, y, en sentido negativo, al precursor de las glicoproteínas de la superficie, GN/GC (G1 y G2), involucrado en la transmisión por el vector. El ARN S ( 2.9 kb), también con arreglo ambisentido, codifica en sentido positivo a una proteína relacionada con el silenciamiento génico (NSs), y en sentido negativo, a la nucleoproteína $\mathrm{N}$ de la cápside (De Haan et al., 1990; Kormelink et al., 1992; 1994; Pappu et al., 2009; Whitfield et al., 2005). Estudios recientes también relacionan a la proteína NSs con la adquisición y acumulación de partículas por el vector (Margaria et al., 2014).

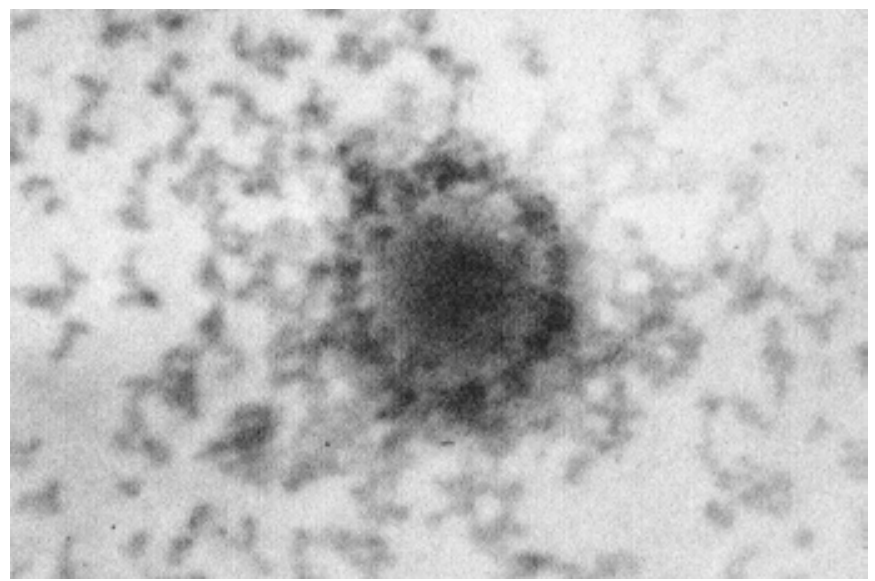

Figura 32. Partícula de TSWV observada al microscopio electrónico. Foto D. Maeso.

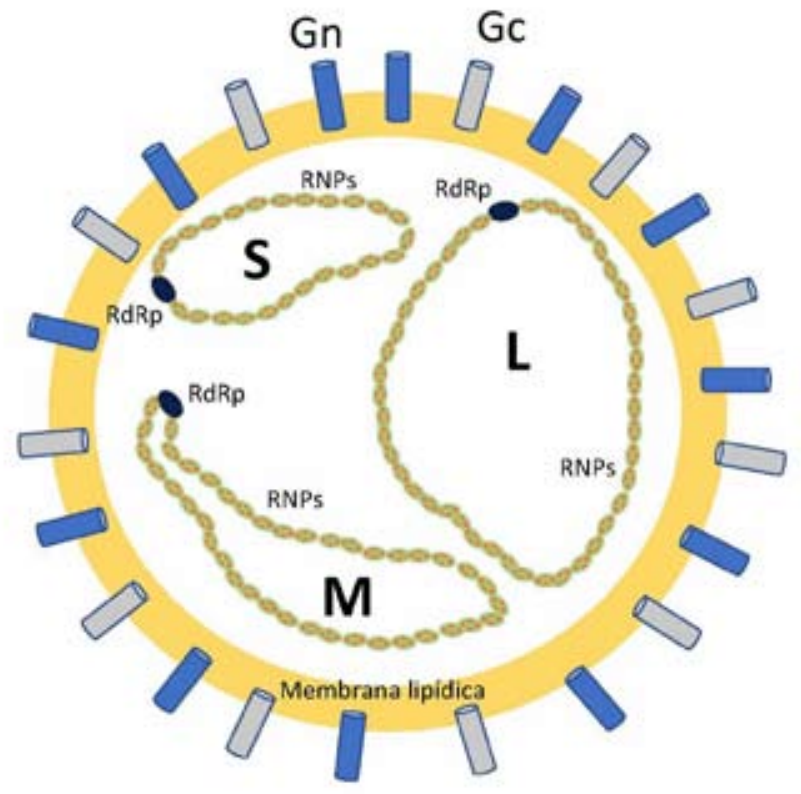

Figura 33. Esquema ilustrativo de la composición de una partícula de orthostospovirus. L, M y $S$ son los segmentos de genoma ( $L$ grande, M medio y $S$ pequeño). RdRp es la ARN polimerasa ARN dependiente. RNPs ribo nucleoproteínas, Gn y Gc glicoproteínas. 


\section{Especies de Orthotospovirus que afectan tomate y morrón en la región}

Luego de conocerse que la enfermedad podía ser causada por varias especies de Orthotospovirus se realizaron numerosos trabajos a nivel mundial tendientes a determinar específicamente la identidad de los agentes, entre los cuales mencionaremos a los correspondientes a nuestra región.

\section{Argentina}

En Argentina esta enfermedad, existe desde comienzos del 1900, pero fue descrita por primera vez como causada por virus por Fawcet (1938) (citado por Granval de Millán y Gracia, 1999). Hasta el momento se han identificado tres especies en tomate y morrón en Argentina que presentan diferente distribución geográfica, fruto de la diversidad de huéspedes y vectores entre regiones: Tomato spotted wilt virus (TSWV) en el Valle del Rio Negro y el sur, incluyendo la región hortícola de La Plata, Tomato chlorotic spot virus (TCSV) en el Noreste y Groundnut ringspot virus (GRSV) en las regiones Noroeste y centro, (Dewey et al., 1996; Gracia et al., 1999; Williams et al., 2001; Dal Bó, 2011).

\section{Brasil}

En Brasil se ha descrito una gran variedad de orthotospovirus en múltiples cultivos, lo cual puede ser explicado en parte por su extensión y diversidad, pero también por el trabajo de destacados especialistas referentes en estos virus a nivel mundial. Entre ellos podemos mencionar a TSWV, TCSV, GRSV (de Ávila et al.,1993; 1993a), Chrysanthemum stem necrosis virus (CSNV), Zucchini lethal chlorosis virus (ZLCV) (Bezerra et al., 1999) e Iris yellow spot virus (IYSV) (Pozzer et al., 1999).

GRSV es el prevalente en tomate y morrón (41\%) frente a TCSV (9\%) y TSWV (4\%), (Martinez et al., 2019). La presencia de TCSV es emergente y muy vinculada con el reordenamiento genómico ya explicado en párrafos anteriores. Algo diferente ocurre en el sur del estado de Florida, EE. UU. y el Caribe en donde TCSV, considerado también como emergente, predomina sobre otros Orthotospovirus en esos cultivos y malezas (Webster et al., 2015; Baker y Adkins, 2015; Warfield et al., 2015; Raid et al., 2015; Estévez de Jensen et al., 2017; Poudel et al., 2019). Lovato et al. (2004) reportan valores de $81 \%$ y $79 \%$ de homología en las secuencias del gen de la glicoproteína de TCSV y GRSV con respecto a TSWV por lo que constituirían especies diferentes a este.

\section{Uruguay}

En nuestro país, si bien no existen reportes formales de los agentes involucrados, prospecciones realizadas desde 2007 utilizando técnicas serológicas y moleculares, indican la presencia de GRSV y TSWV infectando tomate y morrón (Cuadro 2). En un principio los análisis fueron realizados mediante la técnica de ELISA indirecto con antisueros monoclonales para GRSV, TSWV y TCSV gentilmente cedidos por el Dr. de Ávila (EMBRAPA CNPH, Brasilia). A partir de 2009 los análisis se realizaron mediante la técnica DAS-ELISA con antisueros comerciales de la empresa AGDIA (AGDIA Inc.; Indiana, EE. UU.). En ese caso se utilizaron dos reactivos que mezclaban antisueros monoclonales para TSWV+INSV y GRSV+TCSV. La adjudicación de la especie de virus involucrada se realizó en base a la mayor coloración de la reacción lograda con el antisuero específico (Maeso et. al.; 2005; 2009; Bernal et al., 2007). 
Desde 2014 se incorporó la técnica de PCR en la identificación y se realizaron 33 análisis que confirmaron la presencia de ambos virus, con prevalencia de TSWV sobre GRSV en morrón y paridad en tomate (Arruabarrena com. pers.; datos no publicados; Rubio et al, 2014).

Cuadro 2. Detección de especies de orthotospovirus en muestras de plantas de tomate y morrón con síntomas de peste negra en Uruguay1.

\begin{tabular}{|c|c|c|c|c|c|}
\hline \multirow[b]{2}{*}{ Cultivo } & \multirow[b]{2}{*}{ Temporada } & \multirow[b]{2}{*}{ Zona } & \multicolumn{3}{|c|}{ Número de muestras } \\
\hline & & & $\begin{array}{c}\text { Con } \\
\text { detección de } \\
\text { TSWV }\end{array}$ & $\begin{array}{c}\text { Con } \\
\text { detección de } \\
\text { GRSV }\end{array}$ & Total \\
\hline \multirow{5}{*}{ Morrón } & $\begin{array}{l}2007 \\
2009 \\
2010 \\
2012 \\
2014 \\
2018\end{array}$ & Norte & $\begin{array}{c}2 \\
0 \\
4 \\
8 \\
20 \\
0 \\
\end{array}$ & $\begin{array}{c}0 \\
13 \\
0 \\
0 \\
3 \\
4 \\
\end{array}$ & $\begin{array}{c}2 \\
13 \\
4 \\
8 \\
23 \\
4 \\
\end{array}$ \\
\hline & \multicolumn{2}{|c|}{ Total morrón norte } & 34 & 20 & 54 \\
\hline & $\begin{array}{l}2012 \\
2013 \\
2014 \\
2018 \\
2019\end{array}$ & Sur & $\begin{array}{c}283 \\
53 \\
3 \\
57 \\
8\end{array}$ & $\begin{array}{l}0 \\
1 \\
0 \\
0 \\
0\end{array}$ & $\begin{array}{c}283 \\
54 \\
3 \\
57 \\
8\end{array}$ \\
\hline & \multicolumn{2}{|c|}{ Total morrón sur } & 404 & 1 & 405 \\
\hline & \multicolumn{2}{|c|}{ Total morrón } & 438 & 21 & 459 \\
\hline \multirow{5}{*}{ Tomate } & $\begin{array}{l}2007 \\
2008 \\
2009 \\
2014 \\
\end{array}$ & Norte & $\begin{array}{l}5 \\
0 \\
0 \\
3 \\
\end{array}$ & $\begin{array}{l}1 \\
1 \\
5 \\
4 \\
\end{array}$ & $\begin{array}{l}6 \\
1 \\
5 \\
7 \\
\end{array}$ \\
\hline & \multicolumn{2}{|c|}{ Total tomate norte } & 8 & 11 & 19 \\
\hline & $\begin{array}{l}2007 \\
2009\end{array}$ & Sur & $\begin{array}{l}0 \\
0\end{array}$ & $\begin{array}{c}4 \\
23\end{array}$ & $\begin{array}{c}4 \\
23\end{array}$ \\
\hline & \multicolumn{2}{|c|}{ Total tomate sur } & 0 & 27 & 27 \\
\hline & \multicolumn{2}{|c|}{ Total tomate } & 8 & 38 & 46 \\
\hline \multicolumn{3}{|c|}{ Total } & 446 & 59 & 505 \\
\hline
\end{tabular}

1 Los análisis fueron realizados por la técnica serológica de ELISA, salvo los de 2014 que fueron llevados a cabo por PCR. 


\section{MÉTODOS DE DETECCIÓN}

La detección de estos virus ha avanzado muchísimo en las últimas décadas, impulsada por la abundante información disponible. En un principio el diagnóstico se basaba en la reacción de plantas indicadoras herbáceas, luego se desarrollaron las técnicas serológicas, y finalmente, en el momento actual, están disponibles refinadas técnicas moleculares que permiten, no solo detectar e identificar los agentes, sino estudiar múltiples detalles de este grupo de virus. Cada una de ellas brinda diferentes prestaciones según el interés del usuario, como ser simplicidad, bajo costo, sensibilidad, precisión, o rapidez.

Una limitante que aún persiste deriva de la distribución irregular del patógeno en el huésped por lo que se recomienda realizar los análisis en muestras de tejidos jóvenes en activo crecimiento, extraídos de varias partes de la planta y, preferentemente, con síntomas.

Cuando es necesario realizar un diagnóstico preciso, al igual que con otros virus es imprescindible la complementación de varios métodos. En esta sección simplemente se describirán algunos de los métodos y sus características por lo que por mayores detalles se recomienda consultar publicaciones específicas (EPPO, 2004; IPPC, 2017)

\section{Plantas indicadoras}

Los orthotospovirus pueden ser trasmitidos mecánicamente a plantas indicadoras herbáceas utilizando jugos de plantas infectadas mediante raspado con la ayuda de abrasivos (carborundo, celite). Como son partículas muy inestables, la molienda del inóculo deber realizarse usando buffers que contengan antioxidantes (dietil ditio-carbamato DIECA, sulfito de sodio, mercaptoetanol, etc.; Mandal et al., 2001) y, en lo posible manteniendo la temperatura del macerado baja.

Los síntomas que se desarrollan en un rango de indicadoras, también llamadas diferenciales, tuvieron valor diagnóstico en el pasado (Norris, 1946). Si bien la técnica es fácil de ejecutar, tiene cierto grado de subjetividad y es muy dependiente de las condiciones ambientales en que son mantenidas las plantas inoculadas. Esto último implica gastos importantes, ya que para obtener los mejores resultados se debe mantener la temperatura durante la incubación en el rango de $20-25^{\circ} \mathrm{C}$ y evitar el ingreso de vectores para lo cual es necesario contar con instalaciones especiales.

En el Cuadro 3 se muestra una lista de las principales especies utilizadas para estos virus y los síntomas que desarrollan. En general existen dos tipos de plantas indicadoras. Un primer tipo son aquellas que desarrollan síntomas rápidamente luno o dos días después de inoculadas), generalmente lesiones locales, como por ejemplo Nicotiana glutinosa L.; Chenopodium quinoa Wild. y Petunia $\times$ hybrida hort. ex E. Vilm. (Figura 34). Estas plantas únicamente son utilizadas para diagnóstico, porque, como las lesiones corresponden a reacciones de hipersensibilidad, los virus generalmente no se propagan en su interior. El segundo tipo son huéspedes, que, si bien en un comienzo pueden presentar lesiones locales, luego desarrollan síntomas sistémicos y permiten que el virus alcance altas concentraciones en 
su interior. Gracias a ellas se puede realizar la purificación de las partículas y desarrollar reactivos serológicos (Figura 35). La inoculación a plantas indicadoras fue ajustada y utilizada en forma rutinaria para el estudio de esta enfermedad en la Estación Experimental Las Brujas hace ya casi cuatro décadas (Lasa y Tezuka, 1980; Lasa, 1982), aunque actualmente solo se utiliza para algunos fines específicos.

Un aspecto para mencionar en el mantenimiento de aislados de orthotospovirus por esta técnica es que la reiterada inoculación mecánica favorece el desarrollo de formas infectivas defectuosas (DIs) que van perdiendo la capacidad de generar la enfermedad lle, 1982; Verkleij y Peters, 1983; Resende et al., 1991). Por esa razón, para mantener aislados particulares, es necesaria su transmisión periódica mediante el vector.

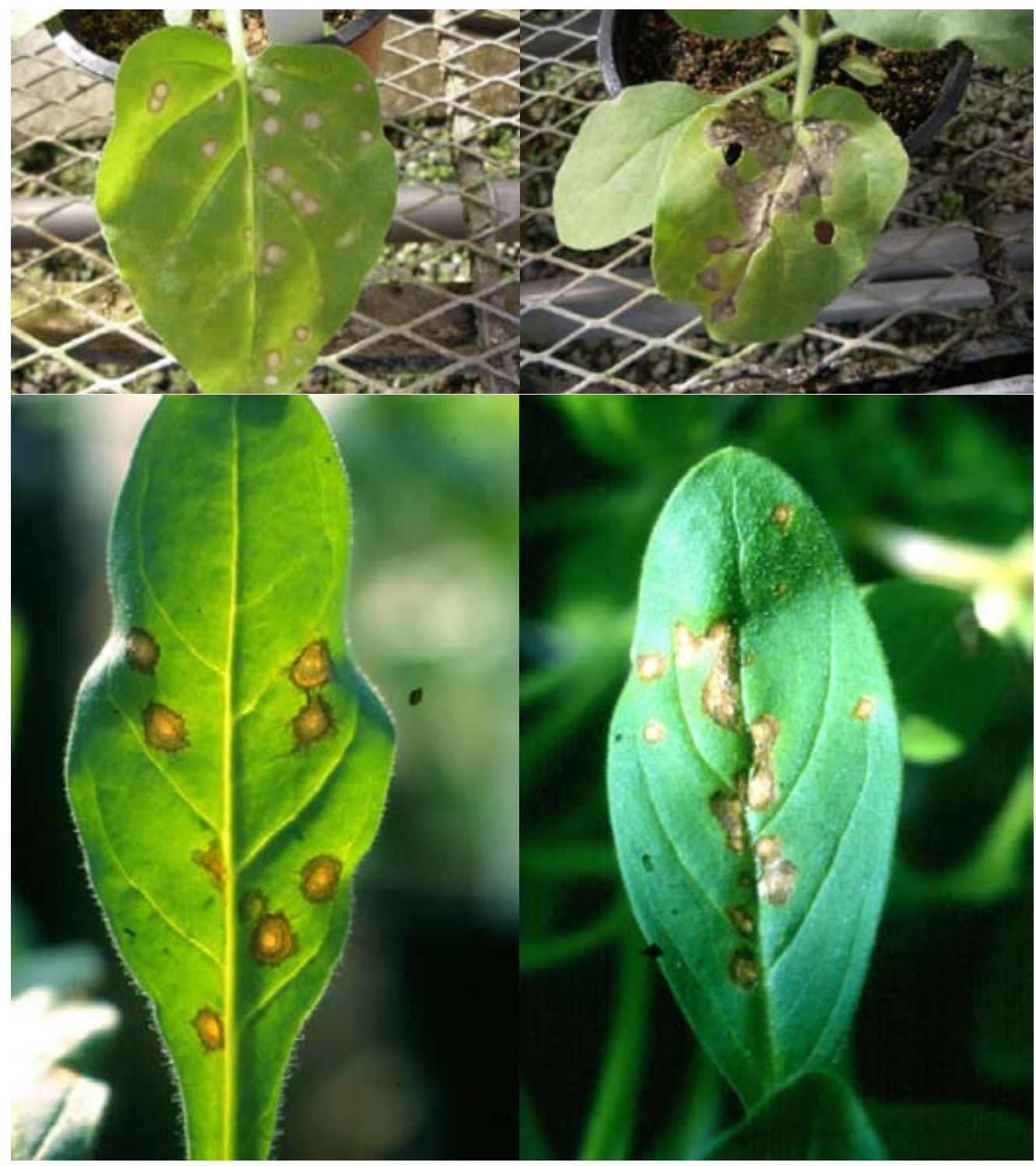

Figura 34. Lesiones locales desarrolladas en diferentes plantas indicadoras luego de la inoculación mecánica con orthotospovirus. Nicotiana glutinosa (arriba) y Petunia hybrida (abajo). Fotos D. Maeso. 
* あ

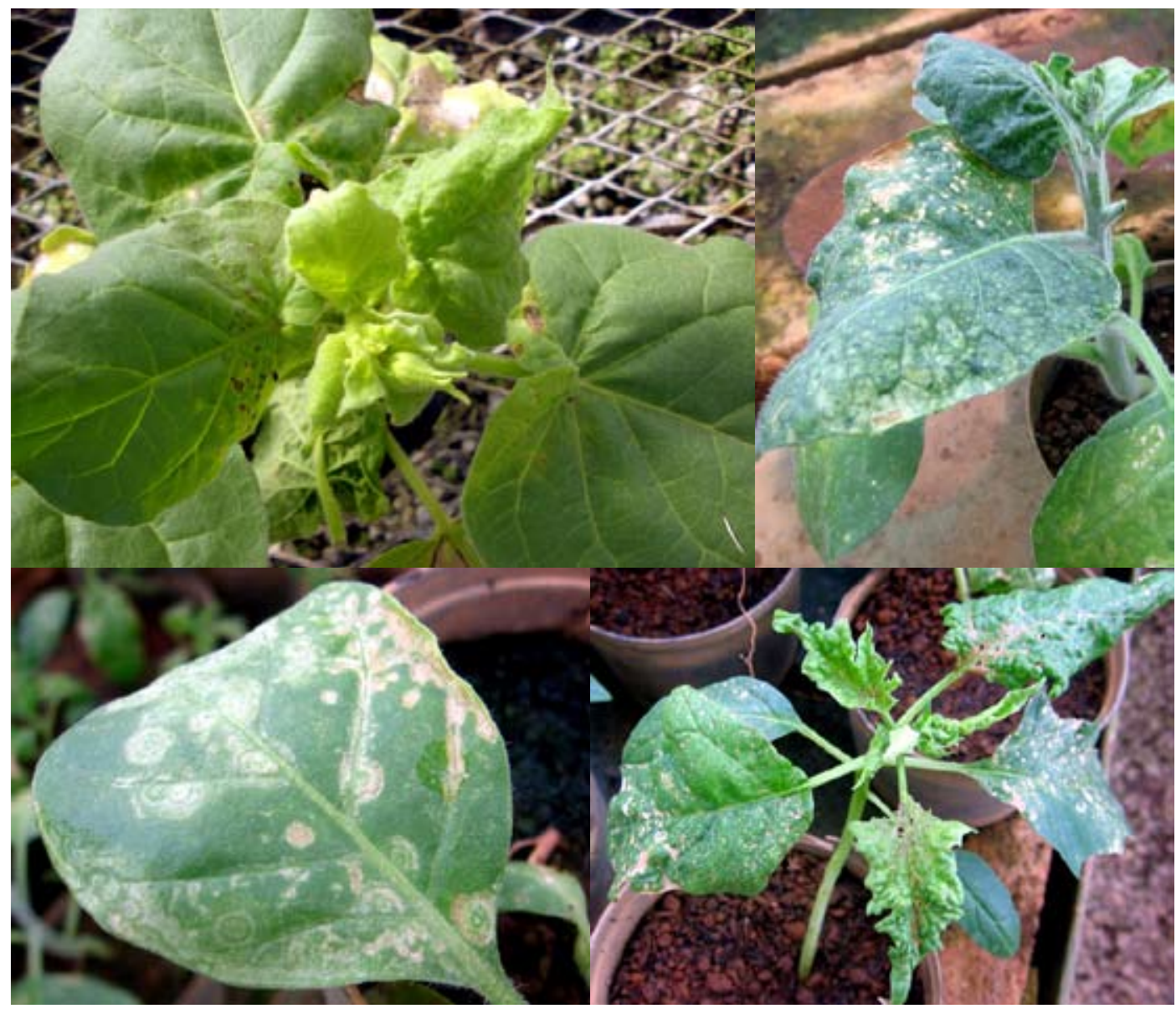

Figura 35. Síntomas sistémicos en algunas plantas indicadoras herbáceas. Arriba y abajo izquierda: Nicotiana spp. y abajo derecha Datura stramonium. Fotos D. Maeso. 
Cuadro 3. Síntomas en algunas de las plantas indicadoras comúnmente usadas ladaptado de Lasa,1982; Kormerlink, 2005; IPPC 2017).

\begin{tabular}{|c|c|c|}
\hline Indicadora & Síntoma & $\begin{array}{l}\text { Estado vegetativo } \\
\text { para inoculación }\end{array}$ \\
\hline Cucumis sativus & $\begin{array}{l}\text { manchas cloróticas con centros } \\
\text { necróticos en los cotiledones no } \\
\text { sistémico }\end{array}$ & $\begin{array}{l}\text { Cotiledones, iniciación } \\
\text { de primera hoja }\end{array}$ \\
\hline Petunia $\times$ hybrida & $\begin{array}{l}\text { lesiones locales necróticas en hojas } \\
\text { inoculadas, no sistémico }\end{array}$ & 6-8 hojas \\
\hline $\begin{array}{l}\text { Nicotiana glutinosa, } \\
\text { N. tabacum, N. rustica }\end{array}$ & $\begin{array}{l}\text { lesiones locales necróticas, } \\
\text { dibujos necróticos sistémicos y } \\
\text { deformación foliar }\end{array}$ & 6-8 hojas \\
\hline Alegría (Impatiens sp.) & $\begin{array}{l}\text { manchas cloróticas a necróticas } \\
\text { o anillos en hojas inoculadas. } \\
\text { Manchas cloróticas a necróticas } \\
\text { sistémicas }\end{array}$ & 6-8 hojas \\
\hline $\begin{array}{l}\text { Datura stramonium } \\
\text { (Chamico) }\end{array}$ & $\begin{array}{l}\text { Manchas cloróticas y necróticas } \\
\text { y anillos en hojas inoculadas. } \\
\text { Mosaico sistémico y moteado. }\end{array}$ & 5-7 hojas \\
\hline Nicotiana benthamiana & $\begin{array}{l}\text { Manchas cloróticas a necróticas, } \\
\text { anillos cloróticos a necróticos } \\
\text { en hojas inoculadas. Clorosis } \\
\text { sistémica, enanismo. }\end{array}$ & 6-8 hojas \\
\hline Lycopersicon esculentum & $\begin{array}{l}\text { Manchas cloróticas a necróticas } \\
\text { y anillos en hojas inoculadas. } \\
\text { Mosaico sistémico, clorosis } \\
\text { sistémica y manchas necróticas }\end{array}$ & 6-8 hojas \\
\hline Gomphrena globosa & Lesiones locales necróticas & 6-8 hojas \\
\hline Tropaeolum majus & $\begin{array}{l}\text { Sin síntomas locales, clorosis y } \\
\text { patrones cloróticos sistémicos. }\end{array}$ & 4-5 hojas \\
\hline Vigna ugniculata & $\begin{array}{l}\text { Lesiones locales necróticas a la } \\
\text { semana de inoculación. }\end{array}$ & Hojas primarias \\
\hline $\begin{array}{l}\text { Chenopodium quinoa, } \\
\text { C. amaranticolor }\end{array}$ & $\begin{array}{l}\text { Lesiones locales cloróticas } \\
\text { seguidas de síntomas sistémicos. }\end{array}$ & 8-10 hojas \\
\hline
\end{tabular}




\section{Técnicas serológicas}

El desarrollo de las técnicas serológicas utilizando antisueros diseñados para la proteína $\mathrm{N}$, significó un gran cambio en el diagnóstico de estos virus (Sherwood et al., 1989; Wang y Gonsalves, 1990; de Ávila et al., 1990; Feldhoff et al., 1997) ya que hasta ese momento la producción de antisueros de buena calidad se veía dificultada por la presencia de la cubierta lipídica. Estos reactivos facilitaron la detección en laboratorio y aún en condiciones de campo y, además contribuyeron con la identificación de especies. Respecto a esto último se debe tener en cuenta que, por el alto grado de homología, muchas especies comparten reacción serológica, por lo que las diferencias se visualizan a través de la intensidad de la reacción desarrollada utilizando antisueros monoclonales de cada una de ellas (de Ávila et al., 1990).

La prueba más utilizada es el ELISA (Enzyme linked immunosorbent assay) en todas sus variantes (Wang y Gonsalves, 1990; de Ávila et al., 1990; Resende et al., 1991) existiendo actualmente reactivos comerciales de varias empresas con capacidad de discriminar especies. En nuestros trabajos hemos utilizado la variante DAS-ELISA ldoble sandwich de antisueros) en forma rutinaria que nos ha permitido la detección eficaz, aún en plantas sin síntomas (Figura 36).

Otra variante de esta técnica que hemos utilizado es el "dot blot ELISA", “DIBA-dot immunobinding assay" o "NC-ELISA" (Hugenot et al., 1990) (Figura 36), la cual es muy similar al ELISA en placa, pero en ella el soporte de la reacción es una membrana de nitrocelulosa. Tiene la ventaja que las muestras pueden ser procesadas en el campo simplemente presionando cortes frescos de tejido sobre la membrana, almacenarla y luego continuar con el resto de las etapas en el laboratorio. Mediante esta técnica hemos realizado la detección de estos virus, en plantas y en trips (Figura 37) en experimentos epidemiológicos entre los que pudimos estimar la proporción de vectores que portaban virus, basándonos en el protocolo diseñado por Aramburu et al. (1996).

También se encuentran disponibles para estos virus kits para realizar una técnica llamada RIPA, "rapid immunofilter paper assay", de muy de fácil ejecución, que brinda resultados rápidos (Tsuda et al., 1992; López Lambertini et al., 2003). Una de ellas es comercializada con el nombre de ImmunoStrip ${ }^{\circledR}$ (AGDIA, Indiana, EE. UU.). La reacción se puede realizar completamente en condiciones de campo y los resultados son muy fáciles de interpretar (dos líneas planta infectada, una línea sana) lo cual es un apoyo muy importante en la erradicación de plantas enfermas. 


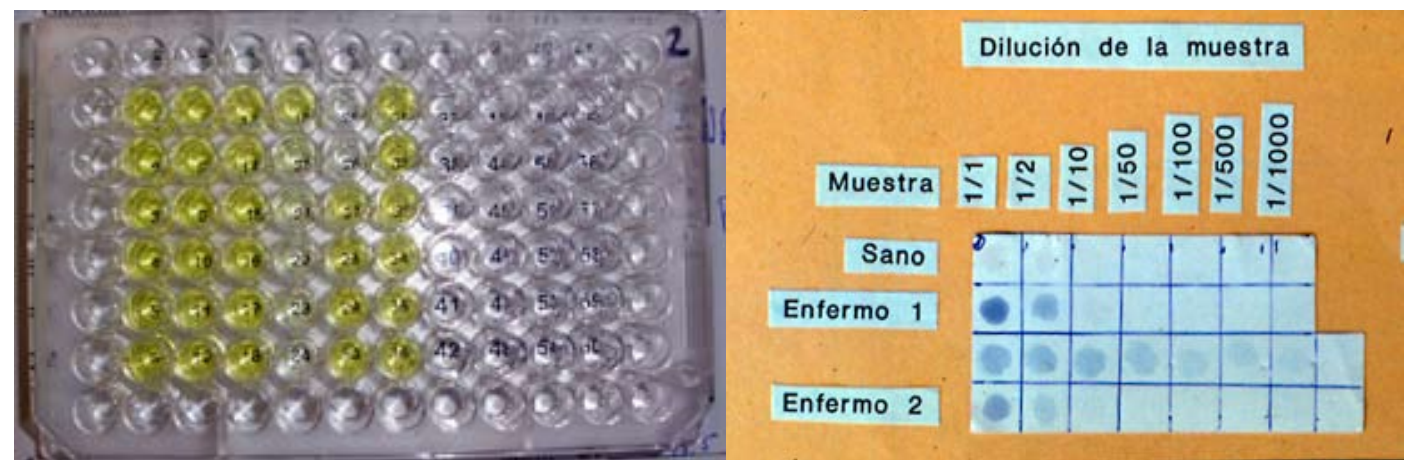

Figura 36. Detección serológica de orthotospovirus. Izquierda, vista de una placa de DAS-ELISA en etapa final, los hoyos con coloración amarilla significan que la muestra contenía virus. Derecha NC-ELISA, coloración violácea en muestras con virus. Fotos D. Maeso.

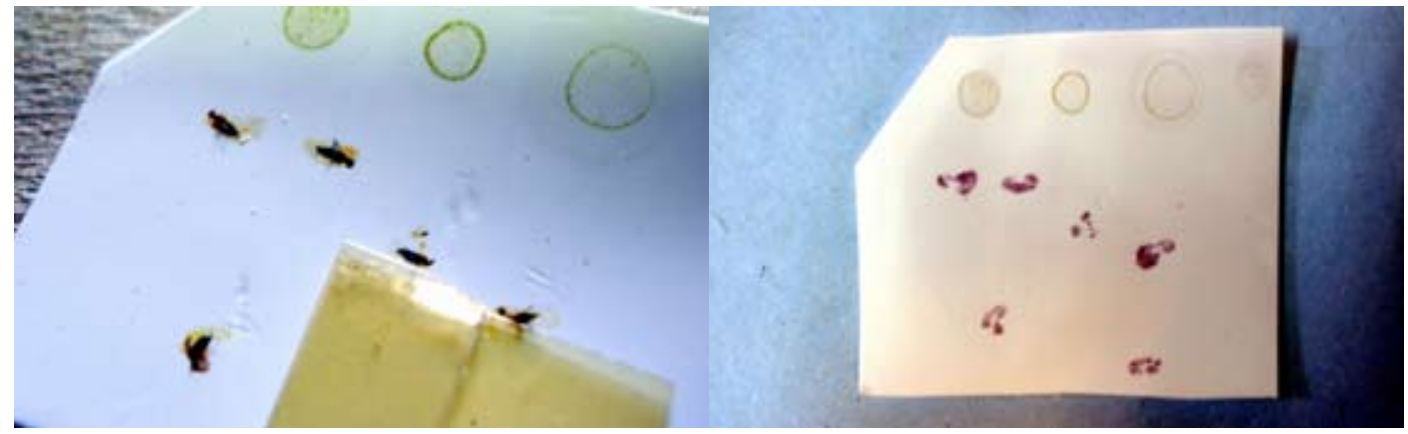

Figura 37. Detección serológica de orthotospovirus en trips mediante la técnica NC-ELISA. En los lugares con insectos que contienen virus se desarrolla coloración violácea. Fotos D. Maeso.

\section{Reacción en cadena de la polimerasa (PCR)}

Como ocurrió con muchos otros patógenos vegetales, el desarrollo de técnicas moleculares brinda amplias oportunidades y ha permitido mejorar el diagnóstico y profundizar en el conocimiento de estos virus. Desde sus inicios con el uso de sondas de cADN (Cho et al., 1989; Ronco et al., 1989), pasando por las diferentes variantes de PCR, los aportes han sido abundantes, no solo en diagnóstico sino en el conocimiento de la enfermedad.

La bibliografía es amplia en cuanto a técnicas, protocolos y primers utilizados, tanto para la detección como para el estudio en profundidad del genoma de estos virus por lo que el lector interesado en el tema puede referirse a ellas (Mumford et al., 1994; 1996b; Eiras et al., 2001; EPPO, 2004; Roberts et al., 2000; Lunello, 2004; Schneider et al., 2004; Debrecszeni et al., 2011; Liu et al., 2017). Esta técnica también permite detectar virus en ejemplares individuales de trips (Boonham et al., 2002) superando algunas restricciones del método mencionado anteriormente (falsos positivos y subjetividad).

Como mencionamos en apartados anteriores, mediante técnicas de PCR se complementó el conocimiento de las especies de orthotospovirus presentes en Uruguay en morrón y tomate. Esta tecnología se ajustó y se lleva a cabo en INIA Salto Grande. Para ello se utilizan primers universales que amplifican el ARN-S de estos virus con posterior análisis de los 
fragmentos de restricción producidos por la enzima Xbal que permite discriminar entre las especies (Mumford et al., 1996b). Complementariamente, se realiza la detección de TSWV por PCR utilizando primers específicos para el ARN-L (Arruabarrena com. pers.). El ajuste y empleo de estas técnicas han contribuido considerablemente en este tema y además son un importante apoyo para el programa de mejoramiento de tomate de INIA (Rubio et al., 2014; Arruabarrena et al., 2015). En la Figura 38 se muestran algunos ejemplos de resultados de análisis de detección de orthotospovirus mediante RT-PCR en plantas de tomate y morrón con síntomas (Arruabarrena com. pers.).
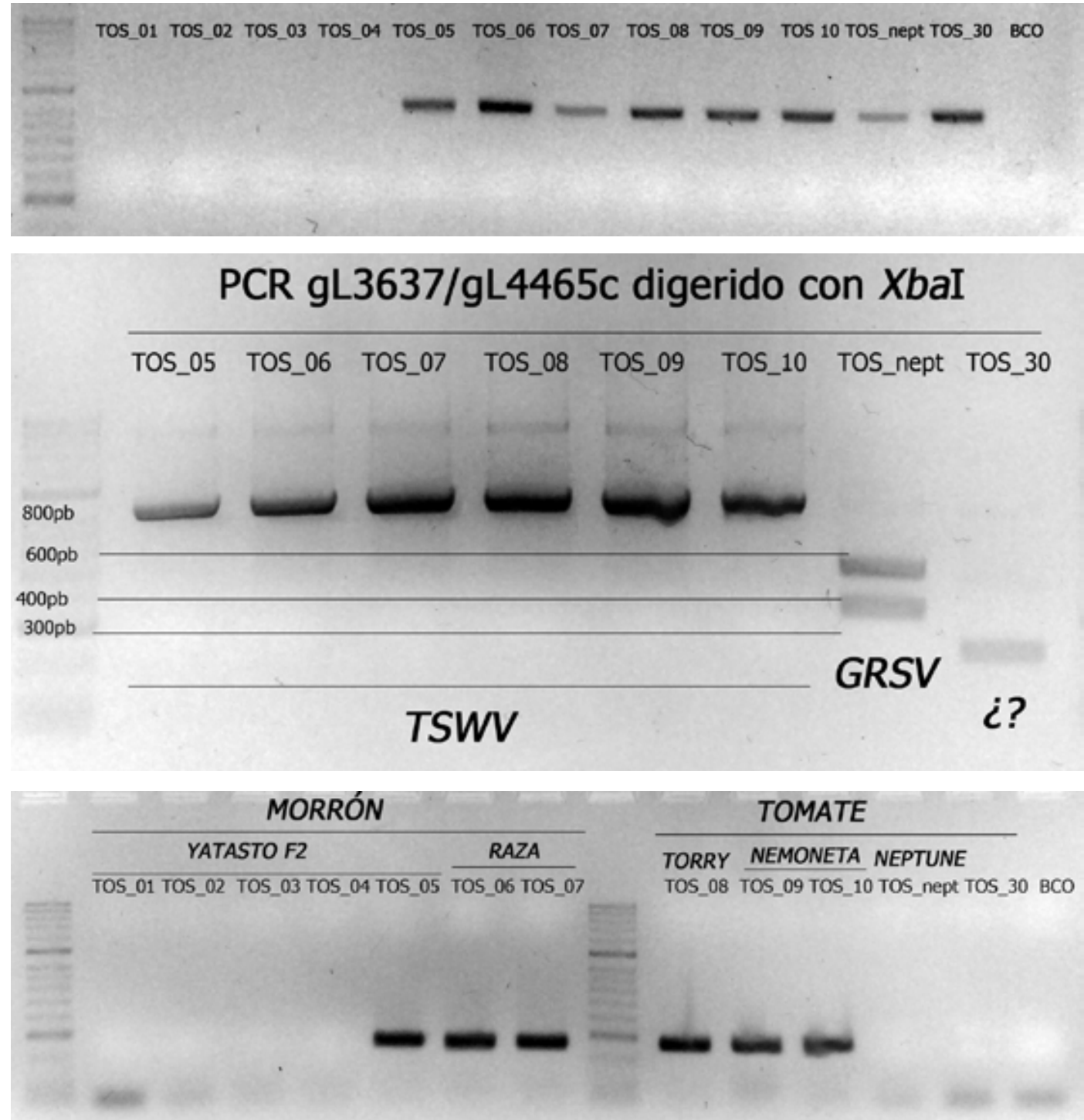

TSWV: PCR específico

Figura 38. Detección molecular de orthotospovirus en Uruguay. Arriba: resultado de RT-PC utilizando primers universales para Orthotospovirus. Centro: patrón de productos de la digestión con la enzima de restricción XBal que permite discriminar entre TSWV y GRSV. Abajo: productos de la amplificación con primers específicos para TSWV. Fotos A. Arruabarrena. 


\section{FACTORES QUE INFLUYEN EN EL DESARROLLO E INTENSIDAD DE SÍNTOMAS}

Un aspecto relevante en esta enfermedad es que las plantas infectadas tienen un período variable, y a veces prolongado, hasta que comienzan a mostrar síntomas, lo cual debe ser considerado en el manejo de la enfermedad. Ese período, dependiendo de las condiciones climáticas puede ser superior a las tres semanas.

La diversidad e intensidad de los síntomas depende del huésped, cultivar, edad de la planta, estación de cultivo, condiciones ambientales, e incluso del origen de la infección (German et al., 1992; Llamas-Llamas et al., 1998). De más está recordar que la especie y/o aislado del virus involucrado también incide sobre el tipo e intensidad de los síntomas aspecto a su vez muy relacionado con cada huésped y vector (Roca et al., 1997).

\section{Edad de la planta}

Al igual que con muchas virosis, la infección temprana en la vida de la planta produce los daños más importantes. A modo de ejemplo Moriones et al. (1998) encontraron que las plantas infectadas naturalmente en cultivos de tomate al aire libre a los 24,38 y 45 días pos-trasplante mostraban mayores perjuicios por la enfermedad frente a las plantas infectadas a los 60,67 y 74 días pos-trasplante (menor número de frutos, menor peso individual y rendimiento). Sin embargo, en todos los casos la calidad de los frutos se vio reducida, aún por las afecciones derivadas de infecciones tardías (Moriones et al, 1998).

\section{Condiciones ambientales}

En general, hasta cierto punto en que comienzan a ser letales para el patógeno, las temperaturas más altas favorecen la multiplicación del virus en la planta y por lo tanto el desarrollo de los síntomas asociados. A modo de ejemplo, Llamas-Llamas et al. (1998) compararon la evolución de la enfermedad bajo dos regímenes de temperatura: 1) diurna $29^{\circ} \mathrm{C} \pm 2$ y nocturna $24^{\circ} \mathrm{C} \pm 3$ y 2) diurna $23^{\circ} \mathrm{C} \pm 1$ y nocturna $18^{\circ} \mathrm{C} \pm 2$ en tres huéspedes (tabaco, Datura stramonium y Physalis ixocarpal. En todos los huéspedes la mayor incidencia, severidad y sistemia de los síntomas se observaron en el régimen de temperaturas más altas.

\section{Duración entre la inoculación y aparición de síntomas}

Como ya se mencionó, uno de los problemas en el manejo de esta enfermedad es que las plantas infectadas pueden permanecer varios días sin manifestar síntomas lo cual dificulta la erradicación de potenciales fuentes de inóculo. La duración de ese período depende, entre otras cosas, de la edad de la planta al momento de la infección. En un estudio de seguimiento de la evolución de infecciones realizado en cultivos de tomate en invernáculo durante el período 1998-2000 se trató de estimar el tiempo entre la detección serológica de TSWV y la aparición de síntomas (Maeso et al., 2005). Para ello se realizaron análisis sero- 
lógicos y evaluación de síntomas en grupos de 30 plantas en dos cultivos de tomate cultivar Dominique durante octubre-enero en las temporadas 1998-1999 y 1999-2000. En la Figura 39 se puede observar que el período entre la detección y la aparición de síntomas tendió a ser menor en las primeras etapas del cultivo después del trasplante $y$, por lo tanto, a medida que avanzó el ciclo existió mayor presencia de plantas infectadas que no expresaron síntomas. Si bien se trata de una estimación, podemos ver que en algunas plantas pasaron más de 20 días entre la detección serológica y el desarrollo de síntomas.

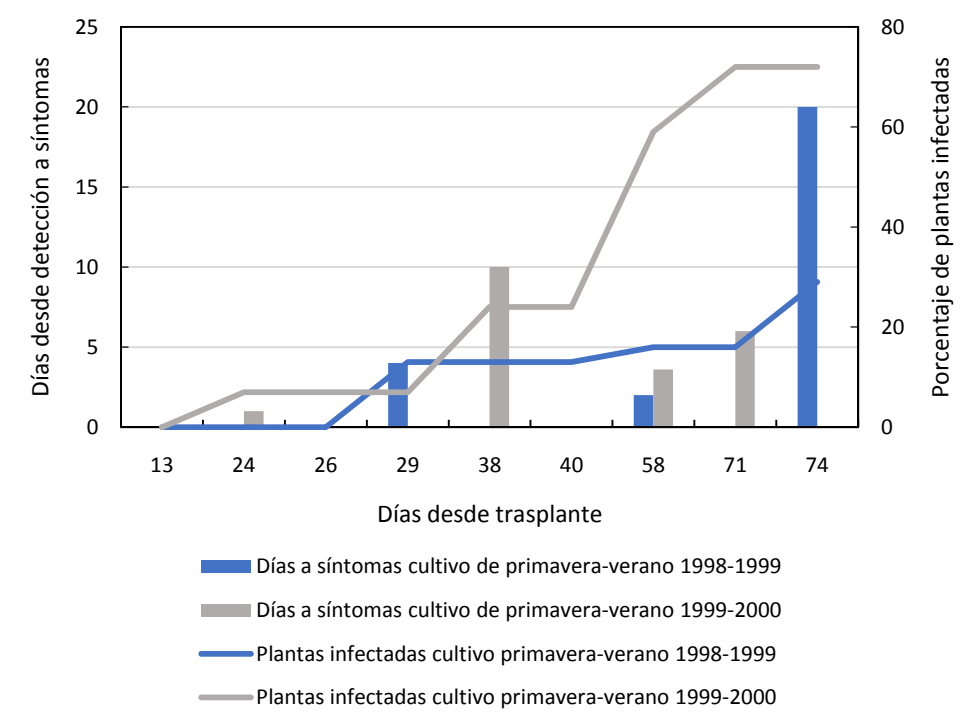

Figura 39. Duración del período desde la detección de TSWV (mediante técnica DAS ELISA) a la aparición de síntomas (días) y evolución del porcentaje de plantas infectadas en experimentos de seguimiento de ataques en tomate en invernadero (1998-2000). Nota: cuando las plantas infectadas no exhibieron síntomas se les asignó un valor arbitrario de 20 días a la duración de la latencia.

\section{CICLO DE LA ENFERMEDAD Y EPIDEMIOLOGÍA}

Para entender el ciclo de esta enfermedad y su epidemiología se deben considerar sus tres componentes principales: virus (especies, aislados y/o serotipos), vectores y plantas huéspedes, principalmente las que sirven a la vez de huéspedes del virus y del vector. Los grandes ataques ocurren cuando estos tres elementos coinciden en las condiciones ambientales apropiadas (German et al., 1992).

La única vía de trasmisión de la enfermedad en condiciones naturales es a través del insecto vector, no transmitiéndose por semilla o contacto entre plantas. Por lo tanto, los vectores juegan un rol crítico cuando en un área coexisten huéspedes susceptibles y fuentes de virus. La presencia, prevalencia, magnitud, localización y tipo de las fuentes de inóculo son factores determinantes de la dimensión de los ataques.

El papel de los parámetros climáticos, de los aislados de virus, la dinámica poblacional del vector, las malezas huéspedes, y la disposición de los cultivos huéspedes en relación con las fuentes de inóculo han sido estudiados en numerosos trabajos (Groves et al., 2001; 2002; Coutts et al., 2004; Okazaki et al., 2007; Stumpf y Kennedy, 2007). 


\section{INSECTOS VECTORES}

Los primeros reportes de los trips (familia Thripidae, orden Thysanoptera) como vectores de Orthotospovirus datan de 1927 (Chatzivassiliou et al., 1999). A pesar de que existen más de 5000 especies, solo poco más de dieciséis son vectores (Jones, 2005) y, ocho, específicamente de los agentes que ocasionan peste negra en tomate y morrón.

Los trips son insectos de tamaño muy pequeño. Los adultos, dependiendo de la especie, miden entre 1-2 mm aproximadamente. Su ciclo de vida consta de: huevo, dos estados larvales (L1 y L2), dos estados pupales quiescentes (pupa y prepupa) y adulto (Reitz, 2009). En la Figura 42 se muestra un esquema simplificado con la duración de cada estado según lo estimado por Bellenda y Guarinoni (1985) para F. schultzei en Uruguay relacionado con el ciclo de la enfermedad. Los adultos y las larvas habitan en flores y otras áreas de la planta como frutos, follaje y yemas florales, mientras que las pupas lo hacen en el suelo o en restos vegetales (Reitz, 2009).

Las larvas y adultos presentan un aparato bucal raedor-chupador con el cual para alimentarse provocan heridas superficiales en la epidermis y succionan el contenido del mesófilo subyacente. Poseen dos tipos de alimentación, en uno realizan pruebas de corta duración en las que salivan y vacían el contenido de pocas células cercanas a la epidermis y en otro, menos frecuente, las pruebas son de mayor duración con un período corto de salivación seguido de un período largo de ingestión. Se piensa que la transmisión se realiza durante las pruebas cortas superficiales y que las pruebas largas son responsables de la adquisición de virus y de los daños severos como plaga (Whitfield et al., 2005).

La forma de transmisión es del tipo persistente, circulativa y propagativa (Sakimura, 1962; Mound, 1996; Whitfield et al., 2005; Jones, 2005). Dado que como ya hemos mencionado, los orthotospovirus fueron en un comienzo patógenos de trips, la selectividad y la íntima relación virus-vector, con circulación y propagación dentro de este, serían producto de su coevolución. (Mound, 2001). Esto explicaría las alteraciones que la infección con orthostospovirus provoca en estos insectos tales como larvas más pequeñas que demoran más en llegar a adultos, menor supervivencia de adultos y menor potencial reproductivo reportadas (De Angelis, 1993; Stumpf y Kennedy, 2005; Inoue y Sakurai, 2006; Shrestha et al., 2012). Sin embargo, esto no fue observado en otros estudios (Sakimura, 1963; Wijkamp et al., 1996) e incluso, algunos reportan mayor supervivencia y longevidad de individuos de F. occidentalis criados en plantas infectadas con TSWV (Ogada et al., 2013; Maris et al., 2004) así como mayor oviposición y rapidez en el desarrollo de larvas (Maris et al., 2004). Estos "beneficios" son explicados por algunos autores por cambios en los mecanismos de defensa inducida del huésped (Abe et al., 2012). Según ellos, la alimentación de trips activa los mecanismos de defensa de las plantas contra herbívoros por la vía de jasmonato (JA), que vuelven a las plantas menos apetecibles para el insecto. Sin embargo, la infección con TSWV a su vez, activa la resistencia inducida por la vía del ácido salicílico (SA) antagónica con la anterior que vuelve nuevamente apetecibles a las plantas infectadas para la alimentación y oviposición del vector, favoreciendo así la trasmisión de la enfermedad. 


\section{Especies de trips trasmisores}

Por el momento cinco son las especies del género Frankliniella (F. bispinosa, F. fusca, F. intonsa, F. occidentalis, y F. schultzei) y tres de Thrips (T. setosus, T. palmi, y T. tabaci) citadas como vectores de TSWV, GRSV y TCSV (Mound, 1996; Ullman et al., 2002; Whitfield et al., 2005; Oliver y Whitfield, 2016), siendo las principales F. occidentalis, F.schultzei y Thrips tabaci (Latham y Jones, 1997).

Hasta la década de 1990, F. schultzei y T. tabaci predominaban en muchas regiones, incluido Uruguay (Briozzo, 1982), y los ataques fuertes de la enfermedad se registraban en intervalos cada varios años (Tezuka y Lasa, 1982). A partir de ese momento, la distribución geográfica de $F$. occidentalis aumentó, lo cual volvió más frecuentes y severos a los ataques (Clift y Tesoriero, 2001). Algo similar ha ocurrido en Argentina, en donde De Santis (1995) reporta por primera vez a F. occidentalis, el cual junto a F. schultzei, F. gemina y $T$. tabaci se citan como vectores de peste negra (De Borbón et al., 2006). Estas especies también fueron identificadas en Uruguay vinculadas a cultivos hortícolas, frutícolas y malezas (Ruffinelli y Carbonell, 1953; Briozzo, 1982; Mujica et al., 2007).

La presencia de F. occidentalis, F. schultzei y $T$. tabaci en flores de morrón y de malezas asociadas, tanto en la zona norte como sur del país fue confirmada en estudios recientes realizados por INIA entre 2017-2019 (datos aún no publicados).

En los trabajos de la zona sur se contabilizó semanalmente la presencia de individuos en flores de morrón y de las especies de malezas presentes dentro y fuera de ocho invernáculos del departamento de Canelones (diez flores por huésped por visita). Las especies fueron identificadas en el laboratorio de entomología de INIA Salto Grande por V. Galván y J. Buenahora con la supervisión del Dr. De Borbón (INTA Mendoza). En la Figura 40 se presenta la información resumida como porcentaje promedio de presencia de cada especie por estación en el total de flores examinadas. De acuerdo con esos datos, F. occidentalis fue la especie más frecuente en las flores de morrón durante verano y otoño, mientras que $T$. tabaci lo hizo en primavera. No se hace un análisis de cantidad de individuos debido a que la identificación solo se hizo en una porción de la colecta. Se puede suponer que, al igual que ocurrió en otras regiones, F. schultzei, la especie originalmente reportada en Uruguay (Briozzo, 1982), fue desplazada por F. occidentalis en este cultivo. En la misma figura se puede apreciar que, si bien la magnitud del número de individuos colectados en cada estación fue diferente, y que la información no tiene en cuenta la cantidad de individuos, las tres especies se encuentran en las flores de las malezas localizadas dentro y fuera del invernáculo y durante casi todo el año. 


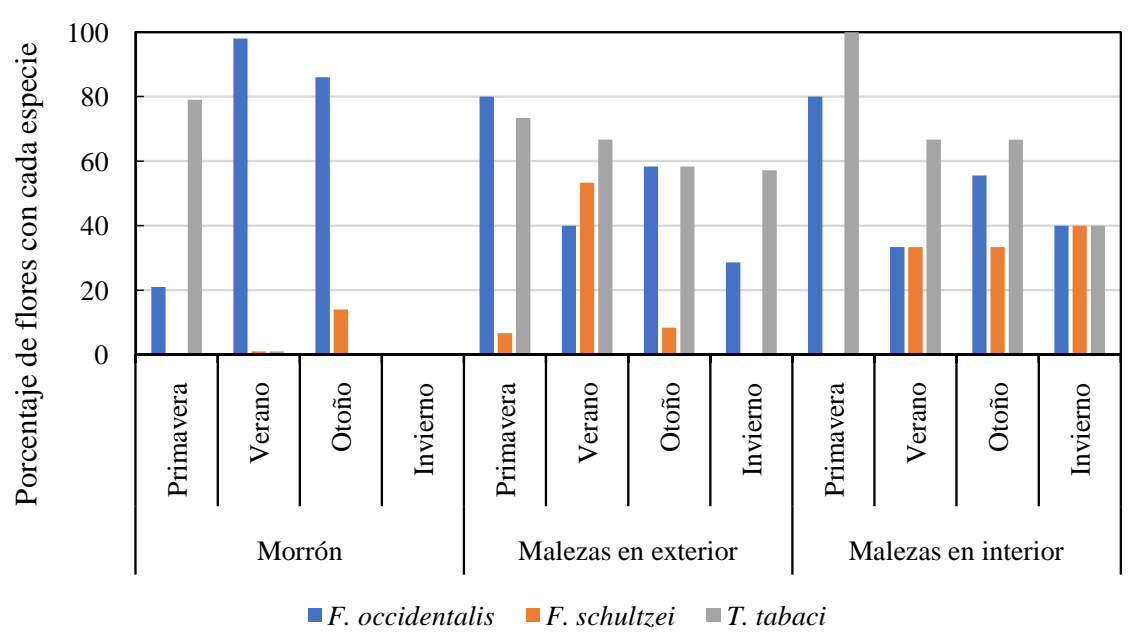

Figura 40. Presencia de identificación de especies de trips en flores de morrón y malezas por estación. En porcentaje promedio de flores con presencia de cada especie en el total de flores examinadas de morrón y de las principales malezas dentro y fuera de los invernáculos. En cada visita se colectaron diez flores por cada maleza. Datos de colectas semanales en ocho invernáculos del departamento de Canelones 2017-2019.

\section{Influencia de las condiciones ambientales en el ciclo de vida de los trips}

Se ha demostrado que la temperatura influye sobre la tasa de crecimiento poblacional y de reproducción, sobre la duración de cada estadio y del ciclo total de vida de los trips. Dentro de ciertos límites, al aumentar la temperatura aumentan las tasas y se acortan la duración de los ciclos, lo cual se traduce en un mayor número de individuos y de generaciones en una estación de cultivo determinada (Shipp y Gillespie, 1993; Gaum et al., 1994; van Rijn et al., 1995; McDonald et al., 1998). Según Chaisuekul y Riley (2005) la temperatura óptima de oviposición para F. occidentalis y $F$. fusca fue de 24,5 y $24,9^{\circ} \mathrm{C}$, respectivamente. La oviposición de ambas fue mayor a mayor duración del fotoperíodo (18:6).

Varios autores han reportado que cuando se superan los $35^{\circ} \mathrm{C}$ se afectan muchos valores vitales del insecto (van Rijn et al., 1995; Okazaki et al., 2007). Park et al. (2020) mencionan el efecto negativo de las grandes variaciones en la temperatura, a pesar de que el valor promedio del periodo fuera favorable. En el otro extremo, se ha verificado su capacidad de sobrevivir a temperaturas bajas tanto como $-5^{\circ} \mathrm{C}$ (Okazaki et al., 2007) lo cual explicaría la supervivencia entre estaciones en regiones como la nuestra.

Como referencia, a $28^{\circ} \mathrm{C}$ los huevos de F. occidentalis eclosionan en 3-5 días, siendo la duración de los estados larvales de 3-6 días y algo superior la de los estados pupales (German et al., 1992). Valores similares fueron encontrados en estudios realizados en nuestro país con $F$. schultzei (Figura 42, Bellenda y Guarinoni, 1985). La duración total del ciclo de F. occidentalis a $25^{\circ} \mathrm{C}$ fue estimada en 12,1 días (Okazaki et al., 2007). La longevidad de los adultos es variable y es afectada por la infección con virus, lo cual, tiene gran relación con la existencia o no de ciclos secundarios de trasmisión dentro de un cultivo. En el cuadro 4, adaptado de Roselló et al. (1996), se presentan estimaciones de la duración del ciclo de vida de las tres especies vectores de relevancia en nuestra región en condiciones ambientales contrastantes. 
Cuadro 4. Duración del ciclo de vida de tres especies de trips vectores de peste negra (adaptado de Roselló et al., 1996)

\begin{tabular}{|c|c|c|}
\hline Especie & Duración del ciclo de vida & Condiciones \\
\hline \multirow{2}{*}{ Frankliniella occidentalis } & $9-12$ días & $30^{\circ} \mathrm{C}$ \\
\cline { 2 - 3 } & $35-39$ días & $15^{\circ} \mathrm{C}$ \\
\hline \multirow{2}{*}{ F. schultzei } & $9-16$ días & Cálidas y secas \\
\cline { 2 - 3 } & 5 semanas & Frío \\
\hline \multirow{2}{*}{ T. tabaci } & $17-18$ días & Verano \\
\cline { 2 - 3 } & 38 días & Invierno \\
\hline
\end{tabular}

La humedad relativa también tiene importancia, habiéndose encontrado efectos negativos en el desarrollo y supervivencia de larvas y adultos y sobre el empupado con valores menores a $80 \%$ (Shipp y Gillespie, 1993; Steiner et al., 2011). Sin embargo, está relacionada con muchos otros factores por lo que su influencia en el comportamiento del vector es difícil de predecir (German et al., 1992).

Los cambios en condiciones ambientales afectan también a la emergencia y la sobrevivencia de las plantas que sirven como puentes para el virus y el vector. También afectan a la uniformidad de la germinación y emergencia y el vigor de las plantas del cultivo, así como el desarrollo de la enfermedad en las plantas inoculadas (Mandal et al., 2002), por lo cual existe una gran interacción entre todos estos factores que puede traducirse en cambios en los ataques de la enfermedad.

\section{Diferencias en la capacidad trasmisora}

La estrecha relación entre los orthotospovirus y sus insectos vectores juega un papel primordial en el desarrollo de la enfermedad, existiendo diferencias en la eficiencia de trasmisión. En general se acepta que las especies del género Frankliniella son más eficientes en adquirir y transmitir estos virus a tomate y morrón frente a Thrips tabaci (Chatzivassiliou et al., 1999), destacándose la capacidad de F. occidentalis (German et al., 1992; Wijkamp et a1.;1995; Ullman, 1996; Mound, 2002; Whitfield et al., 2005). Es por esa razón que, tal como ya mencionamos, se le atribuye a esa especie el incremento reciente en importancia y distribución de la enfermedad.

Con el conocimiento de la existencia de los varios orthotospovirus que producen peste negra en tomate y morrón se han reportado diferencias en la eficiencia de trasmisión por parte de las especies de vectores. Según Wijkamp et al. (1995) F. occidentalis transmite TSWV, INSV, GRSV, y TCSV con eficiencia variable, siendo pobre su trasmisión de GRSV y TCSV. En general se reconoce que $F$. occidentalis es más eficiente trasmitiendo TSWV y F. schultzei a GRSV y TCSV, lo cual seguramente ha incidido en la distribución de estos virus en las diferentes regiones hortícolas (Nagata et al., 2002; 2004; De Borbón et al., 2006). Esto concuerda con los resultados de estudios recientes realizados por INIA, en los que se ha determinado que F. occidentalis es la especie predominante en cultivos de morrón en invernadero, tanto en la zona sur como norte y que TSWV es el virus predominante (datos no publicados, Cuadro 2, Figura 40). 
La capacidad de trasmisión por T. tabaci, si bien fue la primera especie señalada como vector de TSWV, actualmente es discutida (Wijkamp et al., 1995; Ullman, 1996; Chatzivassiliou et al., 1999a; Chatzivassiliou, 2002). Según Wijkamp et al. (1995) depende de las características de la población, siendo ineficiente en poblaciones que poseen solo hembras (telitoquias) y discreta en poblaciones con machos y hembras (arrenotoquia). También se reportó para F. occidentalis mayor eficiencia en trasmisión por parte de machos, lo cual explicaría las diferencias de resultados utilizando diferentes poblaciones (Ogada y Poehling, 2015). Jacobson y Kennedy (2013) señalan que la eficiencia de transmisión de T. tabaci es favorecida cuando la población y el aislado de TSWV en cuestión provienen de la misma zona geográfica, y que esta característica de las poblaciones del insecto es genética y de carácter recesivo. Algo similar se encontró con diferencias en la eficiencia de trasmisión entre poblaciones de F. occidentalis provenientes de diferentes regiones (Van de Wetering et al., 1999) y en la naturaleza genética recesiva de ese carácter (Ogada et al., 2016). Se especula que lo anterior también se deba a aspectos vinculados con la coevolución virus-vector (Whitfield et al., 2005).

Los avances recientes en las técnicas moleculares han aumentado el conocimiento acerca de la interrelación y los determinantes del virus y del vector que modulan la especificidad, así como de los determinantes de las diferencias en eficiencia (Bandla et al., 1998; Sin et al., 2005; Ullman et al., 2005; Whitfield et al., 2005; 2008, Rotenberg et al., 2015). Estudios de códigos de barras genéticos (barcoding) han permitido conocer que las especies de trips vectores son en realidad grupos de "criptoespecies" con mínimas diferencias fenotípicas y eso podría explicar las diferencias en los resultados entre estudios y tener implicancias epidemiológicas (Brunner et al., 2004; Rugman-Jones et al., 2010; Jacobson et al., 2013; Macharia et al., 2015).

\section{Adquisición}

La transmisión de orthotospovirus se lleva a cabo solo por los adultos, y en ocasiones por larvas del segundo instar, siempre y cuando adquieran al virus como larva, lo multipliquen y circule en su interior (Wijkamp et al., 1993; van de Wetering et al., 1996).

La multiplicación en el interior del vector fue puesta en evidencia por el aumento de la proteína viral en el insecto lo cual requiere de ciertos procesos (Nagata et al., 1999; 2002; Wijkamp et al., 1995; van de Wetering et al., 1996). El ciclo del virus dentro del vector comienza con la llegada al intestino medio, en cuyo epitelio se multiplica y posteriormente pasa a las fibras musculares que rodean los intestinos anterior y medio de las larvas en desarrollo (Ogada et al., 2016). De allí llega a las glándulas salivales donde también se multiplica, aumentando su título viral y así facilitar la trasmisión durante la alimentación (Nagata et al., 1999; 2002; Moritz et al., 2004; Ullman et al., 1995). Si bien se ha comprobado la infección de los tejidos del intestino medio en larvas de segundo instar y en adultos, el pasaje a las glándulas salivales en estos estadios está impedido y, por lo tanto, la trasmisión (de Assis Filho et al., 2002; 2004; Stafford-Banks et al., 2014). Se ha determinado en T. tabaci que la adquisición de virus es mayor cuanto menor es la edad de la larva (Chatzivassiliou et al., 2002). 
El proceso inicia cuando las hembras adultas oviponen en hojas de plantas adecuadas para el desarrollo de huevos y larvas (German et al., 1992). Debido a que no hay pasaje transovárico del virus a la progenie (Wijkamp et al., 1996), para que un insecto se vuelva infectivo, este debe necesariamente nacer y desarrollarse sobre una planta enferma, lo cual es un aspecto clave en el desarrollo de la enfermedad (Sakimura, 1962; Wijkamp et al., 1996).

La selección de un huésped para la oviposición se hace según preferencias visuales y olfativas del insecto, luego, su calidad es la que determina el crecimiento de la población, la adquisición y la trasmisión del virus (Wijkamp et al., 1996).

Varios trabajos han estudiado el papel de huéspedes alternativos en el desarrollo de $F$. occidentalis (Cho et al., 1987; Broadbent et al., 1990; Chamberlin et al., 1992; Stobbs et al., 1992; Doederlein y Sites, 1993; Bautista y Mau, 1994; Bautista et al., 1995; Roca et al., 1997; Chatzivassiliou et al., 2001), F. fusca (Hobbs et al., 1993; Groves et al., 2001; 2002; Carrizo y Amela García, 2017) y T. tabaci (Doederlein y Sites, 1993).

Bautista et al. (1995) encontraron mayor oviposición y alimentación de F. occidentalis en $L$. sativa ssp. longifolia (lechuga romana), Malva palviflora (malva) y Arctium lappa (cardo bardana, lampazo), que en $D$. stramonium (chamico) y Verbesina enceloides (girasolcito). Chatzivassiliou et al. (2007) en estudios similares con T. tabaci destacan la oviposición y desarrollo de larvas en tabaco, D. stramonium, Solanum nigrum, L. serriola y Sonchus oleraceous.

Como ya mencionamos, se ha reportado que $F$. occidentalis presenta mayor oviposición, supervivencia y rapidez de desarrollo en plantas infectadas con TSWV de algunos huéspedes, lo cual sugiere un tipo de relación mutualista (Yudin et al., 1990; Maris et al., 2004). Yudin et al. (1990) lo explican por el mayor contenido de aminoácidos libres y la coloración amarilla de las plantas enfermas; lo cual podría tener implicancias epidemiológicas. Otros autores también presentan información similar sosteniendo que los trips vectores se benefician al atacar plantas con virus porque estas son de mejor calidad para desarrollar su descendencia (Bautista et al. 1995; Maris et al., 2004).

Aunque la adquisición del virus por el insecto puede completarse en 5-15 minutos (Sakimura, 1963), en general demora aproximadamente 30 minutos y ocurre durante toda la vida larval. Los trips tienen estructuras en su aparato bucal y su canal alimentario mediante las cuales perciben señales de las plantas en cuanto a su preferencia como sitios de alimentación. Cuando un huésped es apropiado, las larvas se alimentan reiteradamente dejando múltiples heridas (Figura 41), lo cual redunda en la ingesta de múltiples partículas virales y aumenta la proporción de adultos virulíferos.

La idoneidad de una planta, la distribución y concentración de virus en sus tejidos, determinan la cantidad adquirida por una larva y la infectividad de las poblaciones de adultos desarrolladas (German et al., 1992; Ullman et al., 1992).

Como se mencionó, existen varios trabajos que señalan diferencias entre huéspedes respecto a la adquisición del patógeno, lo cual los diferenciaría en cuanto a potencial fuente de inóculo (Bautista et al., 1995; Chatzivassiliou et al., 2007). Es importante resaltar que no 
siempre coinciden los valores de preferencia y cantidad de oviposición con la adquisición y transmisión, dependiendo de las condiciones, de los huéspedes y de la especie del vector en que fueron hechos los estudios (Bautista et al. 1995; Chatzivassiliou et al., 2007).

La preferencia de T. tabaci ha sido estudiada en: Datura stramonium, Lactuca serriola, Sonchus oleraceous, tabaco, Solanum nigrum, Amaranthum retroflexus (Chatzivassiliou et al., 2007) y para F. occidentalis en: D. stramonium, Arctium lappa, L. sativa var. longifolia, Malva parviflora, y Verbesina enceloides (Bautista et al., 1995). Sin entrar en detalles, estos estudios indican diferencias en preferencia, adaptación para el desarrollo larval, adquisición y trasmisión, los cuales deben ser tenidos en cuenta al analizar el desarrollo de epidemias en cultivos comerciales.

Cuando la distribución de virus en una planta es uniforme y su concentración alta, la probabilidad de adquisición aumenta y es un factor para considerar, además de la capacidad de albergar y reproducir al vector, en cuanto a la relevancia como huésped alternativo del patógeno.

También se señala que la magnitud de la alimentación evidenciada por el daño provocado no siempre está relacionada con la trasmisión de la enfermedad, la cual depende, además, como veremos más adelante, de otros factores (Broadbent et al., 1990).

Una vez adquirido el virus, este se retiene durante la muda, y los adultos emergentes permanecen infectivos durante toda su vida, por lo que a este tipo de trasmisión se le denomina persistente (German et al., 1992; Moritz et al., 2004; Whitfield et al., 2005).

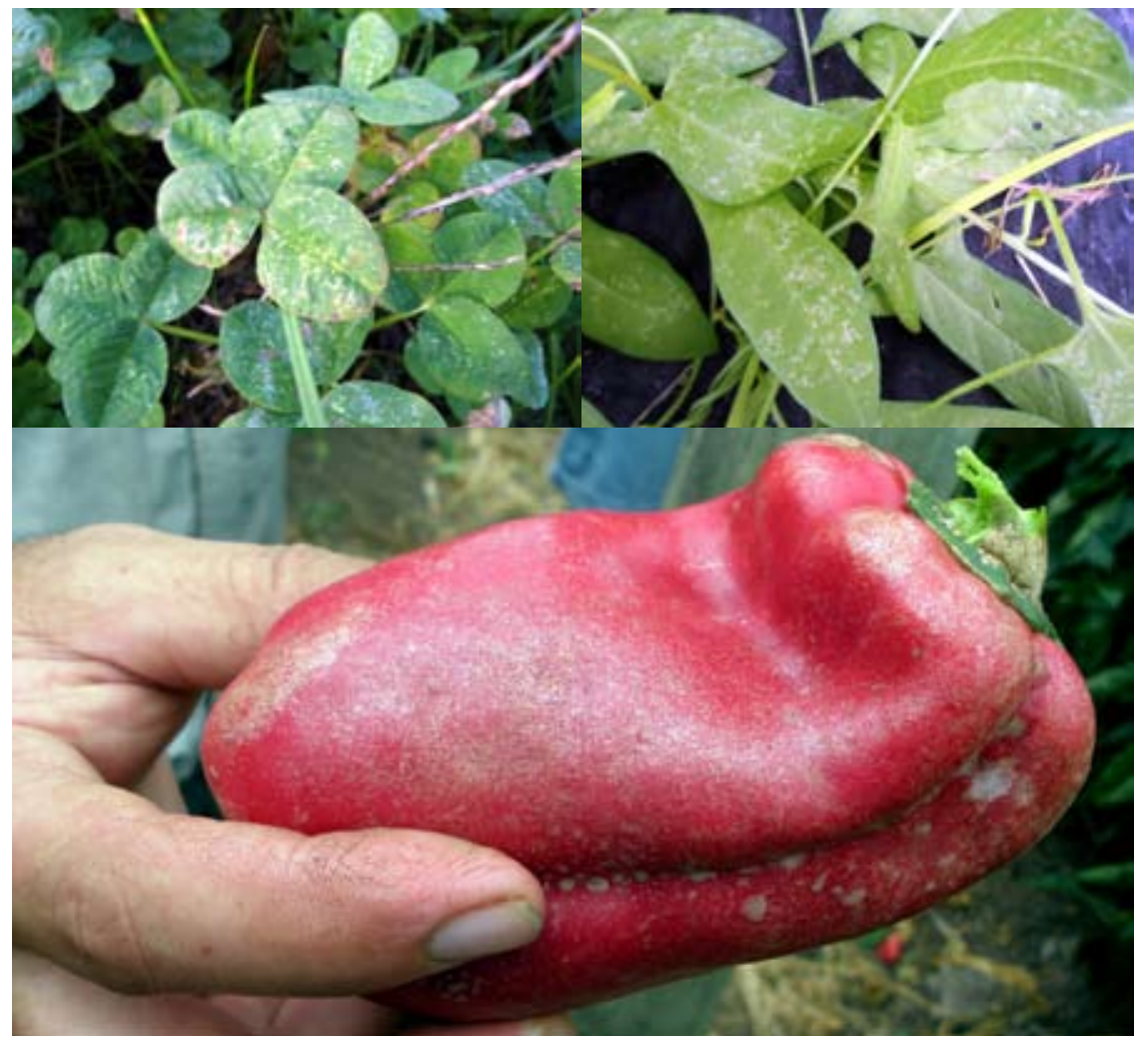

Figura 41. Lesiones en hojas de trébol blanco, corrigüela y fruto de morrón ocasionadas por la alimentación de trips. Fotos D. Maeso. 


\section{Procesos dentro del vector}

Se ha demostrado que los orthotospovirus se propagan y circulan dentro del vector por lo que esta modalidad de transmisión además se denomina como propagativa y circulativa, lo cual evidencia una estrecha relación entre el agente y el vector. La replicación del ARN viral y el ensamble de las partículas virales se produce tanto en la planta como en el insecto y se ha demostrado que este tiene mucha influencia en la infectividad del patógeno (Jones, 2005). Ya hemos mencionado que cuando se mantiene un aislado de TSWV únicamente mediante trasmisión mecánica en indicadores herbáceos, va perdiendo su patogenicidad y su capacidad de ser trasmitido por vectores. Se producen cambios en la cápside y disminución de la producción de glicoproteínas (le, 1982; Verkleij y Peters, 1983) relacionadas con el ARN M (Verkleij y Peters, 1983) que son esenciales en la multiplicación del virus en el insecto (Jones, 2005).

Trabajos recientes aportan información que explica algunas interrogantes sobre este género de virus, generalistas desde el punto de vista del huésped, pero altamente específicos en su relación con el vector. Ruark-Seward et al. (2020) determinaron que la diversidad genética existente en poblaciones de TSWV tiende a disminuir dentro de un huésped por cambios en la proteína $\mathrm{NS}_{\mathrm{m}}$ (vinculada a la movilidad en planta y al rango de huéspedes) buscando la adaptación, pero que esa diversidad se recupera en el pasaje por el vector, lo cual le permite ampliar nuevamente su rango de huéspedes.

El virus adquirido como larva debe estar disponible en las glándulas salivares al momento de la trasmisión como adulto, por lo que debe permanecer en órganos internos que no se modifiquen en la muda y pasar varias barreras internas en el insecto. En los adultos la barrera principal son las células epiteliales del intestino medio que impiden el pasaje de los virus a otros órganos y el movimiento hacia las glándulas salivares, lo cual no ocurre en el estado larval, de ahí que la adquisición solo pueda ser efectiva en ese estado (German et al., 1992).

\section{Trasmisión}

Si bien se ha reportado que la trasmisión puede realizarse a partir del segundo estado larval, eso no es común ya que se requiere un período de 3-10 días de latencia previo dentro del insecto, lo cual es difícil que se pueda completar durante el estado larval. Según Wijkamp y Peters (1993) el período medio de latencia para TSWV e INSV es de 80 horas a $27^{\circ} \mathrm{C}$ y 170 horas a $20^{\circ} \mathrm{C}$ y disminuye con la temperatura (Chatzivassiliou et al., 2002). Además, dada la poca movilidad de las larvas, al no tener alas y no ser arrastradas por el viento, se considera que poseen poca importancia epidemiológica en la trasmisión (Wijkamp et al., 1993). El principal proceso durante ese estado es la propagación del patógeno dentro del vector para generar una gran acumulación de virus en los adultos a la salida del estado pupal (Wijkamp et al., 1993), que determinará la futura capacidad infectiva (Rotenberg et al., 2009).

Los estados de pre-pupa y pupa no se alimentan, por lo tanto no son transmisores, son quiescentes y se encuentran en hojas, flores, o en el suelo, dependiendo de la especie. Sin embargo, juegan un papel importante en el comienzo de la enfermedad en nuevos cultivos. 
El hecho de que no se alimenten las hacen menos susceptibles al control químico, y, a la vez, les da la capacidad de permanecer en suelo, restos vegetales, etc. para, luego de levantados los cultivos, ser fuente de adultos virulíferos que infectarán a los nuevos plantines en almácigos o recién trasplantados (German et al., 1992).

La inoculación del virus a plantas sanas es realizada por los adultos y es mucho más rápida que la adquisición, les insume entre 5-30 minutos, aunque normalmente requiere de más tiempo. Los trips la pueden realizar durante pruebas superficiales y rápidas, aún sin ingestión, lo cual, al producir menos heridas, facilita el acceso del virus a células sanas (Ananthakrishnan y Annadurai, 2007).

Existe evidencia de que la infección con orthotospovirus altera los hábitos alimenticios de F. occidentalis triplicando el número de pruebas, lo cual aumentaría la probabilidad de trasmisión (Stafford et al., 2011), y esa mayor ingesta de alimentos a su vez, compensaría los efectos negativos de la infección con el virus (Stafford-Banks et al., 2014b). Sin embargo, a pesar de haber sido sugerido varias veces, no se ha podido comprobar que los adultos infectados prefieran a las plantas sanas para su alimentación.

Jeger et al. (2015) realizaron una interesante modelización teórica de la adquisición-trasmisión de orthotospovirus por trips tomando en cuenta la información disponible del sistema virus-vector. Desde el punto de vista académico también es relevante el trabajo de Ogada et al. (2016) en el que desarrollan un modelo para explicar la epidemiología de la enfermedad tomando en cuenta el comportamiento y la preferencia del vector por plantas enfermas o sanas para oviposición, desarrollo de su progenie, alimentación; el efecto de la infección con orthotospovirus en la longevidad y la atracción diferencial desarrollada por la diferente relación entre plantas enfermas y sanas en la evolución del ciclo de la enfermedad. Los supuestos utilizados por estos autores en su modelo ayudan a componer la información disponible y citada en los párrafos anteriores.

Ya se mencionó que existen plantas que son muy eficientes para la adquisición, preferidas para colonizar y alimentarse (p.ej. lechuga), y otras que, a pesar de no ser elegidas para colonizar, son muy apropiadas para la trasmisión (p.ej. tomate). Se debe recordar que para la adquisición es importante que el insecto permanezca en la planta durante el estado larval, mientras que para la trasmisión es necesario que el adulto migre, visite y se alimente del mayor número de plantas.

Existen trabajos en los que se reportan mayores índices de trasmisión de TSWV fruto de la preferencia alimenticia de $T$. tabaci por $D$. stramonium, tabaco, Solanum nigrum y L. serriola, (Chatzivassiliou et al., 2007) y de F. occidentalis por D. stramonium, Arctium lappa, y Verbesina enceloides (Bautista et al., 1995).

Son estas diferencias en la preferencia para la adquisición/trasmisión respecto a cultivos/flora las que determinan las características de los procesos epidemiológicos en cada sistema. De esa forma, Chatzivassiliou et al. (2007) determinaron que el comportamiento epidemiológico de esta enfermedad en tabaco es preferentemente monocíclico, siendo las malezas la fuente primaria y con muy poca trasmisión secundaria dentro del cultivo, a pe- 
sar de lo largo de su ciclo debido a que la preferencia del vector por la planta de tabaco no estimula su posterior migración.

Finalmente, es necesario enfatizar que los adultos no portadores de virus, aunque se alimenten de plantas infectadas, no pueden adquirirlo debido a la presencia de la barrera en su intestino medio, como ya se mencionó, y por lo tanto no transmiten la enfermedad, siendo su presencia irrelevante en el avance de esta enfermedad en un cultivo (German et al., 1992; Moritz et al., 2004; Whitfield et al., 2005).

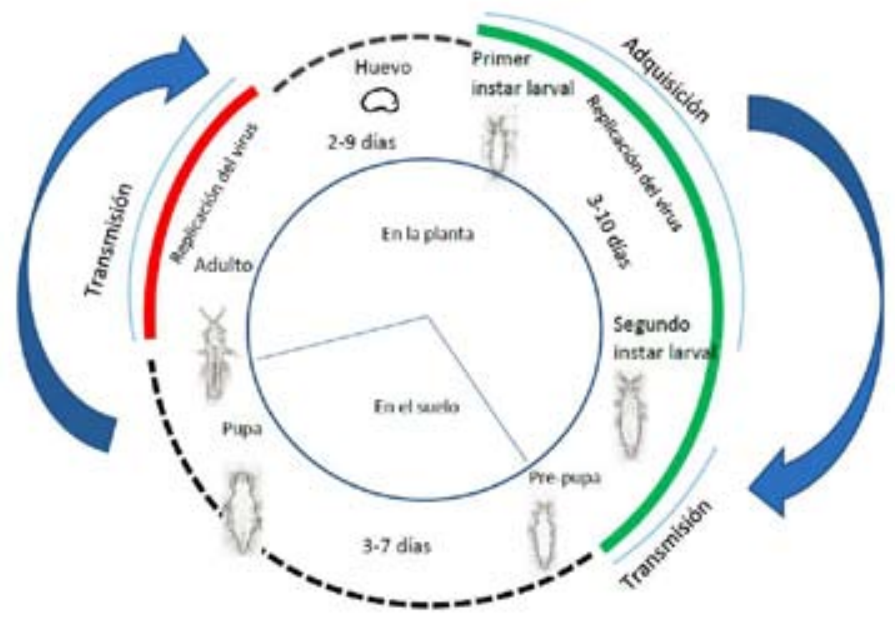

Figura 42. Ciclo de Frankliniella spp. relacionado con la trasmisión de peste negra (modificado de Peters, 2003). Los datos de duración de estadios son los estimados por Bellenda y Guarinoni (1985) para F. schultzei.

\section{HUÉSPEDES}

El hecho de que la adquisición se realice únicamente durante el estado larval determina que, para que la vegetación relacionada al cultivo desempeñe un papel relevante en el desarrollo de la enfermedad, además de ser huéspedes del virus, debe multiplicar al vector. Por lo tanto, su rol en la trasmisión dependerá de la susceptibilidad al virus y de la idoneidad para fomentar la alimentación y oviposición del vector (Kahn et al., 2005). Las plantas muy susceptibles a orthotospovirus pero que no promueven el desarrollo de trips y solamente son visitadas por adultos migrantes no revisten importancia en el ciclo de la enfermedad.

Tanto los vectores como los orthotospovirus causantes de peste negra poseen un amplio rango de hospedantes que abarca cerca de un centenar de familias y más de mil especies botánicas. Existen varias publicaciones que brindan listas detalladas, (Cho et al., 1986b; 1987; Peters et al., 1991; Prins y Goldbach, 1998; Peters, 1998; Parrella et al., 2003; Lovato et al., 2008; Hanssen et al., 2010; EPPO, 2020), por lo que aquí simplemente mencionaremos aquellas que pueden ser importantes en nuestra zona.

Entre los cultivos de importancia económica que son afectados se destacan alcaucil, berenjena, morrón, achicoria, cucurbitáceas (incluyendo pepino, melón y sandía), habas, lechuga, papa, tabaco, tomate, espinaca, endivia, poroto, coliflor y numerosas ornamentales (EPPO, 1998; Zitter y Daughtrey, 1989). 
Dada la gran variedad y número de especies citadas en la bibliografía desde zonas geográficas muy diversas, a fines prácticos se ha hecho una selección, que se presenta en el cuadro 5 , de aquellas presentes en nuestra región y que reúnen las características descritas (huésped de virus y vector). Cabe destacar que el listado no es perfecto, sino que es meramente una guía indicativa para relacionar con situaciones concretas de cultivos de nuestra región y fruto de una exhaustiva búsqueda para brindar información sobre sus nombres comunes, ciclos y períodos de floración.

Cuadro 5. Malezas relevantes como huéspedes alternativos en el desarrollo de epidemias de enfermedades causadas por orthotospovirus en cultivos comerciales'.

\begin{tabular}{|c|c|c|c|c|}
\hline Nombre científico & Nombre común & Ciclo & Floración & Bibliografía \\
\hline \multicolumn{5}{|l|}{ Amaranthaceae } \\
\hline Amaranthus spp. & Yuyo Colorado & $A^{2}$ & $\mathrm{~V}-\mathrm{O}^{3}$ & $\begin{array}{l}\text { Cho et al.,1986; Zitter y } \\
\text { Daughtrey, 1989; Stobbs } \\
\text { et al., 1992; EPPO, } \\
\text { 1998; Fletcher, 2001; } \\
\text { Chatzivassiliou et al., } \\
\text { 2001; Atakan et al., } 2013\end{array}$ \\
\hline \multicolumn{5}{|l|}{ Apiaceae/Umbelliferae } \\
\hline Conium maculatum $L$. & Cicuta & $A / B$ & $\mathrm{P}-\mathrm{V}$ & Stobbs et al., 1992 \\
\hline \multicolumn{5}{|l|}{ Caprifoliaceae } \\
\hline Sambucus nigra $L$. & Saúco negro & $P$ & $\mathrm{P}-\mathrm{V}$ & Meterlik et al., 1996 \\
\hline \multicolumn{5}{|l|}{ Caryophyllaceae } \\
\hline Agrostemma githago L. & Neguilla & A & $\mathrm{P}-\mathrm{V}$ & Stobbs et al., 1992 \\
\hline Cerastium vulgatum $L$. & Capiquí peludo & A & $\mathrm{I}-\mathrm{P}$ & Stobbs et al., 1992 \\
\hline Scleranthus annuus $L$. & Clavelito del médano & $A$ & $\mathrm{P}$ & Groves et al., 2001 \\
\hline Spergula arvensis $L$. & Spergula & $\mathrm{A}$ & $\mathrm{P}-\mathrm{V}-\mathrm{O}$ & Stobbs et al., 1992 \\
\hline Stellaria media (L.) Vill. & Capiquí & $\mathrm{B} / \mathrm{P}$ & $P$ & $\begin{array}{l}\text { Cho et al.,1986; Zitter y } \\
\text { Daughtrey, 1989; Stobbs } \\
\text { et al., 1992; Bitterlich } \\
\text { y Mac Donald, 1993; } \\
\text { EPPO, 1998; Atakan et } \\
\text { al., } 2013\end{array}$ \\
\hline \multicolumn{5}{|l|}{ Chenopodiaceae } \\
\hline Chenopodium spp. & Quinoa & $A$ & V & $\begin{array}{l}\text { Cho et al.,1986; Zitter y } \\
\text { Daughtrey, 1989; Stobbs } \\
\text { et al., 1992; Fletcher, } \\
\text { 2001; Chatzivassiliou et } \\
\text { al., 2001; Atakan et al., } \\
2013 \\
\end{array}$ \\
\hline Salsola kali L. & Cardo ruso & $\mathrm{A}$ & $\mathrm{V}-\mathrm{O}$ & Stobbs et al., 1992 \\
\hline \multicolumn{5}{|l|}{ Commelinaceae } \\
\hline Commelina spp. & Leandro Gómez & $P$ & $P-V$ & $\begin{array}{l}\text { Macharia et al., 2016; Kil } \\
\text { et al., } 2020\end{array}$ \\
\hline
\end{tabular}




\begin{tabular}{|c|c|c|c|c|}
\hline \multicolumn{5}{|l|}{ Compositae/Asteraceae } \\
\hline Ambrosia spp. & Ambrosia/artemisa & A & $\mathrm{V}-\mathrm{O}$ & Stobbs et al., 1992 \\
\hline Bidens spp. & Amor seco & A & 0 & $\begin{array}{l}\text { Zitter y Daughtrey, 1989; } \\
\text { Stobbs et al., 1992; } \\
\text { Persley et al., } 2006\end{array}$ \\
\hline Carduus acanthoides L. & Cardo & $A$ & $P-V$ & Stobbs et al., 1992 \\
\hline Centaurea spp. & Aciano/abrepuños & $\mathrm{A} / \mathrm{B}$ & $\mathrm{V}$ & $\begin{array}{l}\text { Stobbs et al., 1992; } \\
\text { Chatzivassiliou et al., } \\
2001\end{array}$ \\
\hline Cichorium intybus $L$. & Achicoria/radicheta & $\mathrm{A} / \mathrm{B}$ & $\mathrm{P}$ & Stobbs et al., 1992 \\
\hline Cirsium spp. & Cardo negro & $A$ & $\mathrm{~V}$ & $\begin{array}{l}\text { Stobbs et al., 1992; } \\
\text { Bitterlich y Mac Donald, } \\
\text { 1993; Chatzivassiliou et } \\
\text { al., } 2001\end{array}$ \\
\hline Conyza spp. & Yerba carnicera & $A$ & $P-V$ & $\begin{array}{l}\text { Cho et al., 1986; EPPO, } \\
\text { 1998; Chatzivassiliou et } \\
\text { al., } 2001 \text {; Mateus et al., } \\
2012\end{array}$ \\
\hline Crepis sp. & Cerraja peluda & $A$ & V & Stobbs et al., 1992 \\
\hline Galisonga spp. & Albahaca silvestre & $A$ & P-V-O & $\begin{array}{l}\text { Cho et al.,1986; Zitter y } \\
\text { Daughtrey, 1989; Stobbs } \\
\text { et al., 1992; EPPO, } 1998\end{array}$ \\
\hline Gamochaeta falcata Wedd. & Vira-vira & $\mathrm{P}$ & $\mathrm{P}-\mathrm{V}$ & Srinivasan et al., 2014 \\
\hline Gnaphalium spp. & Marcela & $P$ & $P-V$ & $\begin{array}{l}\text { Stobbs et al., 1992; } \\
\text { Groves et al., } 2002\end{array}$ \\
\hline Lactuca spp. & Lechugas silvestres & $A$ & V & $\begin{array}{l}\text { Cho et al., 1986; } \\
\text { Stobbs et al., 1992; } \\
\text { Chatzivassiliou et al., } \\
2001\end{array}$ \\
\hline Matricaria spp. & Manzanilla & $A$ & $P-V$ & $\begin{array}{l}\text { Stobbs et al., 1992; } \\
\text { Carrizo y Amela García, } \\
2017\end{array}$ \\
\hline Picris sp. & Pega pega & $A / P$ & $P-V-O$ & $\begin{array}{l}\text { Chatzivassiliou et al., } \\
2001\end{array}$ \\
\hline Senecio spp. & Senecio & $A / P$ & $\mathrm{~T}$ & $\begin{array}{l}\text { Stobbs et al., 1992; } \\
\text { Bitterlich y Mac Donald, } \\
\text { 1993; EPPO, 1998; } \\
\text { Chatzivassiliou et al., } \\
2001\end{array}$ \\
\hline Silybum marianum L. & Cardo mariano & $A / B$ & $\mathrm{~V}$ & $\begin{array}{l}\text { Chatzivassiliou et al., } \\
2001\end{array}$ \\
\hline
\end{tabular}




\begin{tabular}{|c|c|c|c|c|}
\hline Sonchus spp. & Cerraja & $A$ & $\mathrm{~T}$ & $\begin{array}{l}\text { Cho et al.,1986; Zitter y } \\
\text { Daughtrey, 1989; Stobbs } \\
\text { et al., 1992; Bitterlich } \\
\text { y Mac Donald, 1993; } \\
\text { Lathan y Jones, 1997; } \\
\text { Wilson, 1998; EPPO, } \\
\text { 1998; Chatzivassiliou et } \\
\text { al., } 2001\end{array}$ \\
\hline Taraxacum officinale Weber & Diente de león & $P$ & $P-V$ & $\begin{array}{l}\text { Stobbs et al., 1992; } \\
\text { EPPO, 1998; Carrizo y } \\
\text { Amela García, } 2017\end{array}$ \\
\hline Tussilago farfara $L$. & Farfara & $\mathrm{P}$ & $\mathrm{P}$ & Stobbs et al., 1992 \\
\hline $\begin{array}{l}\text { Verbesina encelioides (Cav.) } \\
\text { Benth. Et Hook, ex Gray. }\end{array}$ & Girasolillo & $A$ & $P-V-O$ & $\begin{array}{l}\text { Cho et al., 1986; Bautista } \\
\text { et al., } 1995\end{array}$ \\
\hline Xanthium spp. & Abrojo, cepacaballo & A & $\mathrm{V}$ & $\begin{array}{l}\text { Stobbs et al., 1992; Cho } \\
\text { et al., } 1996\end{array}$ \\
\hline \multicolumn{5}{|l|}{ Convolvulaceae } \\
\hline $\begin{array}{l}\text { Convolvulus sepium (L.) } \\
\text { R.Br. }\end{array}$ & Campanilla rosada & $P$ & $\mathrm{~V}-\mathrm{O}$ & Stobbs et al., 1992 \\
\hline Convolvulus arvensis L. & Corregüela & $P$ & V & $\begin{array}{l}\text { Stobbs et al., 1992; } \\
\text { Chatzivassiliou et al., } \\
2001\end{array}$ \\
\hline Ipomoea spp. & Campanilla & $A$ & $\mathrm{~V}-\mathrm{O}$ & $\begin{array}{l}\text { Cho et al., 1986; Zitter } \\
\text { y Daughtrey, 1989; } \\
\text { Chatzivassiliou et al., } \\
2001\end{array}$ \\
\hline \multicolumn{5}{|l|}{ Coreopsidae } \\
\hline Coreopsis lanceolata L. & Girasol de jardín & $\mathrm{P}$ & V & Stobbs et al., 1992 \\
\hline \multicolumn{5}{|l|}{ Cruciferae/Brassicaceae } \\
\hline Brassica rapa $L$. & Nabo forrajero & A & $P-V$ & $\begin{array}{l}\text { Carrizo y Amela García, } \\
2017\end{array}$ \\
\hline Capsella bursa-pastoris L. & Bolsa del pastor & A & $P-V$ & $\begin{array}{l}\text { Cho et al.,1986; Zitter y } \\
\text { Daughtrey, 1989; Stobbs } \\
\text { et al., 1992; Bitterlich } \\
\text { y Mac Donald, 1993; } \\
\text { Chatzivassiliou et al., } \\
\text { 2001; Atakan et al., } 2013\end{array}$ \\
\hline Cardamine spp. & $\begin{array}{l}\text { Berrillo, berro } \\
\text { amargo }\end{array}$ & A & I-P & $\begin{array}{l}\text { Stobbs et al., 1992; } \\
\text { Bitterlich y Mac Donald, } \\
1993\end{array}$ \\
\hline Coronopus ssp. & Mastuerzo & $A / B$ & $P-V$ & Cho et al., 1986 \\
\hline Erysimum cheiranthoides $L$. & Alhelí amarillo & $\mathrm{B} / \mathrm{P}$ & $P-V$ & Stobbs et al., 1992 \\
\hline Lepidium spp. & Mastuerzo & $A$ & I-P & Kil et al., 2020 \\
\hline
\end{tabular}




\begin{tabular}{|c|c|c|c|c|}
\hline Raphanus raphanistrum L. & Rábano & $A$ & $\mathrm{P}$ & $\begin{array}{l}\text { Lima et al., 2000; Groves } \\
\text { et al., 2002; Carrizo y } \\
\text { Amela García, } 2017\end{array}$ \\
\hline Raphanus sativus $L$. & Rábano silvestre & $A$ & $\mathrm{P}$ & $\begin{array}{l}\text { Lima et al., 2000; Carrizo } \\
\text { y Amela García, } 2017\end{array}$ \\
\hline Raphistrum rugosum L. & Mostacilla & $A$ & $P-V$ & $\begin{array}{l}\text { Carrizo y Amela García, } \\
2017\end{array}$ \\
\hline Rorippa spp. & Berro & A & $P-V$ & Kil et al., 2020 \\
\hline Sinapis arvensis $L$. & Mostaza silvestre & $A$ & $P-V-O$ & $\begin{array}{l}\text { Lima et al., 2000; } \\
\text { Chatzivassiliou et al., } \\
\text { 2001; Atakan et al., } 2013\end{array}$ \\
\hline \multicolumn{5}{|l|}{ Geraniaceae } \\
\hline $\begin{array}{l}\text { Erodium moschatum (L.) } \\
\text { L'Hér. }\end{array}$ & Alfilerillo & $A$ & I-P & Wilson, 1998 \\
\hline Geranium robertianum L. & $\begin{array}{l}\text { Hierba de San } \\
\text { Roberto }\end{array}$ & $A$ & $P-V$ & $\begin{array}{l}\text { Stobbs et al., 1992; } \\
\text { Bitterlich y Mac Donald, } \\
1993\end{array}$ \\
\hline \multicolumn{5}{|l|}{ Lamiaceae/Labiatae } \\
\hline Ballota nigra L. & Marrubio negro & $P$ & $P-V$ & $\begin{array}{l}\text { Chatzivassiliou et al., } \\
2001\end{array}$ \\
\hline Lamium amplexicaule $L$. & Ortiga mansa & $A$ & I-P & $\begin{array}{l}\text { Stobbs et al., 1992; } \\
\text { Chatzivassiliou et al., } \\
2001\end{array}$ \\
\hline Marrubium vulgare $L$. & Marrubio & $\mathrm{P}$ & $\mathrm{P}-\mathrm{V}$ & Stobbs et al., 1992 \\
\hline Mentha arvensis $L$. & Menta japonesa & $\mathrm{P}$ & $\mathrm{V}$ & Stobbs et al., 1992 \\
\hline Salvia sp. & Salvia & $\mathrm{P}$ & $\mathrm{P}$ & Doederlin y Sites, 1993 \\
\hline \multicolumn{5}{|l|}{ Leguminosae/Fabaceae } \\
\hline $\begin{array}{l}\text { Desmodium tortuosum (Sw.) } \\
\text { DC. }\end{array}$ & $\begin{array}{l}\text { Desmodio verde, } \\
\text { pega pega }\end{array}$ & $P$ & $P-V$ & Johnson et al., 1996 \\
\hline Lupinus spp. & Lupino & $\mathrm{A}$ & $P-V$ & Stobbs et al., 1992 \\
\hline Medicago lupulina L. & Lupulina & $A$ & $P-V$ & $\begin{array}{l}\text { Stobbs et al., 1992; } \\
\text { Bitterlich y Mac Donald, } \\
1993\end{array}$ \\
\hline Medicago polymorpha L. & Trébol carretilla & $A$ & $\mathrm{P}$ & Cho et al., 1986 \\
\hline Melilotus officinalis (L.) Lam. & $\begin{array}{l}\text { Trébol de olor } \\
\text { amarillo }\end{array}$ & $\mathrm{A} / \mathrm{B}$ & $P-V-O$ & $\begin{array}{l}\text { Cho et al.,1986; Zitter y } \\
\text { Daughtrey, 1989; Stobbs } \\
\text { et al., 1992; Atakan et al., } \\
2013\end{array}$ \\
\hline Trifolium repens $L$. & Trébol blanco & $P$ & $\mathrm{~T}$ & $\begin{array}{l}\text { Stobbs et al., 1992; } \\
\text { Wilson 1998; Carrizo y } \\
\text { Amela García, } 2017\end{array}$ \\
\hline
\end{tabular}




\begin{tabular}{|c|c|c|c|c|}
\hline Trifolium spp. & Tréboles & $P$ & $\mathrm{~T}$ & $\begin{array}{l}\text { Chamberlin et al., 1992; } \\
\text { Wilson, 1998; Bitterlich } \\
\text { y Mac Donald, 1993; } \\
\text { Chatzivassiliou et al., } \\
2001\end{array}$ \\
\hline Vicia sp. & Veza común & $A$ & $P$ & $\begin{array}{l}\text { Chatzivassiliou et al., } \\
2001\end{array}$ \\
\hline \multicolumn{5}{|l|}{ Malvaceae } \\
\hline Malva spp. & Malva & $A$ & $P-V$ & $\begin{array}{l}\text { Cho et al., 1986; Zitter y } \\
\text { Daughtrey, 1989; Stobbs } \\
\text { et al., 1992; Bautista y } \\
\text { Mau, 1994; Wilson, 1998; } \\
\text { Chatzivassiliou et al., } \\
2001\end{array}$ \\
\hline \multicolumn{5}{|l|}{ Onagraceae } \\
\hline Oenothera biennis L. & Onagra común & $\mathrm{B}$ & $P-V$ & Stobbs et al., 1992 \\
\hline \multicolumn{5}{|l|}{ Oxalidaceae } \\
\hline Oxalis stricta $L$. & Macachin & $P$ & $P-V$ & $\begin{array}{l}\text { Stobbs et al., 1992; } \\
\text { Bitterlich y Mac Donald, } \\
1993\end{array}$ \\
\hline \multicolumn{5}{|l|}{ Plantaginaceae } \\
\hline Plantago spp. & Llantén & $\mathrm{P}$ & $P-V$ & Stobbs et al., 1992 \\
\hline \multicolumn{5}{|l|}{ Polygonaceae } \\
\hline Polygonum spp. & Sanguinaria & $\mathrm{A} / \mathrm{B}$ & $P-V$ & $\begin{array}{l}\text { Stobbs et al., 1992; } \\
\text { EPPO, } 1998\end{array}$ \\
\hline Rumex crispus L. & Lengua de vaca & $P$ & $\mathrm{P}$ & $\begin{array}{l}\text { Cho et al., 1986; } \\
\text { Stobbs et al., 1992; } \\
\text { Bitterlich y Mac Donald, } \\
\text { 1993; Wilson, 1998; } \\
\text { Chatzivassiliou et al., } \\
\text { 2001; Groves et al., } 2002\end{array}$ \\
\hline \multicolumn{5}{|l|}{ Portulacaceae } \\
\hline Portulaca oleraceae L. & Verdolaga & $A$ & I-P & $\begin{array}{l}\text { Zitter y Daughtery, } \\
\text { 1989; Stobbs et al., } \\
\text { 1992; EPPO, 1998; } \\
\text { Chatzivassiliou et al., } \\
\text { 2001; Atakan et al., } 2013\end{array}$ \\
\hline \multicolumn{5}{|l|}{ Primulaceae } \\
\hline Anagallis arvensis L. & Hierba del pájaro & $A / B$ & P-V-O & Stobbs et al., 1992 \\
\hline \multicolumn{5}{|l|}{ Ranunculaceae } \\
\hline Ranunculus spp. & Abrepuño & $A$ & $P-V$ & $\begin{array}{l}\text { Stobbs et al., 1992; } \\
\text { Atakan et al., } 2013\end{array}$ \\
\hline \multicolumn{5}{|l|}{ Smilacaceae } \\
\hline Smilax spp. & Zarzaparrilla & $\mathrm{P}$ & $\mathrm{I}-\mathrm{P}$ & Kil et al., 2020 \\
\hline
\end{tabular}




\begin{tabular}{|c|c|c|c|c|}
\hline \multicolumn{5}{|l|}{ Solanaceae } \\
\hline Datura spp. & Chamico & A & $P-V$ & $\begin{array}{l}\text { Cho et al., 1986; Tate et } \\
\text { al., 1991; Stobbs et al., } \\
\text { 1992; Bautista y Mau, } \\
\text { 1994; Fletcher, 2001; } \\
\text { Chatzivassiliou et al., } \\
\text { 2001, Mateus et al., } 2012\end{array}$ \\
\hline Lycopersicum spp. & Tomates silvestres & A & V & $\begin{array}{l}\text { Kumar et al., 1995; } \\
\text { Edwardson y Christie, } \\
1997\end{array}$ \\
\hline Nicotiana glauca Graham & Palán-palán & $P$ & V & Yudin et al. 1986 \\
\hline Physalis spp. & Aguaymanto & $A$ & $P-V$ & $\begin{array}{l}\text { Cho et al.,1986; Stobbs } \\
\text { et al., } 1992\end{array}$ \\
\hline Solanum elaeagnifolium Cav. & Quillo & $P$ & $\mathrm{~V}-\mathrm{O}$ & $\begin{array}{l}\text { Doederlin y Sites, 1993; } \\
\text { Chatzivassiliou et al., } \\
2001\end{array}$ \\
\hline $\begin{array}{l}\text { Solanum nigrum L.; S. } \\
\text { americanum Mill.; S. } \\
\text { ptychanthum Dunal }\end{array}$ & Hierba mora & $A$ & $\mathrm{~T}$ & $\begin{array}{l}\text { Cho et al.,1986; Zitter y } \\
\text { Daughtrey, 1989; Tate } \\
\text { et al., 1991; Stobbs } \\
\text { et al., 1992; EPPO, } \\
\text { 1998; Fletcher, 2001; } \\
\text { Chatzivassiliou et al., } \\
2001\end{array}$ \\
\hline \multicolumn{5}{|l|}{ Tropaeoleaceae } \\
\hline Tropaeolum majus $L$. & Taco de reina & $A$ & $P-V$ & $\begin{array}{l}\text { Yudin et al. 1986; Cho } \\
\text { et al., 1986; Zitter y } \\
\text { Daughtrey, } 1989\end{array}$ \\
\hline \multicolumn{5}{|l|}{ Verbenaceae } \\
\hline Verbena spp. & Verbena & $P$ & $P-V$ & $\begin{array}{l}\text { Zitter y Daughtery, 1989; } \\
\text { Stobbs et al., 1992; } \\
\text { Chatzivassiliou et al., } \\
2001\end{array}$ \\
\hline \multicolumn{5}{|l|}{ Zygophyllaceae } \\
\hline Tribulus terrestris $L$. & Roseta francesa & $A$ & $P-V$ & $\begin{array}{l}\text { Chatzivassiliou et al., } \\
2001\end{array}$ \\
\hline
\end{tabular}

'Se tomó en cuenta que fueran huéspedes de TSWV, reprodujeran al vector y que estuvieran citadas en la región.

${ }^{2} A=$ Anual, $B=$ Bianual y $P=$ Perenne

${ }^{3} \mathrm{P}=$ Primavera, $\mathrm{V}=$ Verano, $\mathrm{O}=$ Otoño, $\mathrm{I}=$ Invierno y $\mathrm{T}=$ todo el año

Existen algunos aspectos del huésped, además de los ya mencionados, que definen si una especie es relevante para el desarrollo de ataques de peste negra y determinan las características de las epidemias en el cultivo comercial asociado (Chatzivassiliou et al., 1999; Stumpf y Kennedy, 2005). Uno de los más importantes es que estén presentes en momentos y lugares claves (German et al., 1992; Ullman et al., 1993; Bautista et al., 1995; Cullbreth et al. 2003) y que su trascendencia será diferente según las zonas climáticas y el ciclo del cultivo comercial en cuestión (Bitterlich y MacDonald, 1993; Latham y Jones, 1997; Groves et al., 2002). 
En ese sentido podemos separar a los huéspedes alternativos según su rol. Por un lado, tendríamos aquellos que sirven de "puente verde" permitiendo la supervivencia de virus y vector entre ciclos de cultivo, o cuando las condiciones son poco favorables para el desarrollo de epidemias (Carrizo y Amela García, 2017). En climas áridos, donde la vegetación espontánea no prolifera en ausencia de riego, o en regiones con inviernos muy fríos su papel es poco relevante. Por el contrario, en regiones como la nuestra, constituyen una de las principales fuentes para el inicio de las infecciones. Groves et al. (2001) estudiaron el papel de algunos huéspedes alternativos en el ciclo de la enfermedad en tabaco trasmitida por $F$. fusca, señalando la importancia de Stellaria media (capiquí), Scleranthus annuus (rosetilla), y Sonchus asper (cerraja) en el mantenimiento de la infección viral y como suministro de trips infectivos, aún a distancias de más de $37 \mathrm{~m}$ del cultivo. Algo similar es reportado para esa enfermedad y vector en maní (Groves et al., 2002; Morsello y Kennedy, 2009) con S. media y otros huéspedes alternativos. Johnson et al. (1995) presentan información similar para ese sistema en cultivos de tomate. La invernación de varias especies de trips vectores también ha sido reportada en Sonchus oleraceous (Cho et al., 1995) y Amaranthus retroflexus (Sakimura, 1932). A lo anterior se agrega la poca preferencia por esos huéspedes de la fase adulta que contribuiría al movimiento rápido de vectores en primavera a otras malezas o cultivos.

Por otro lado, estarían los huéspedes alternativos con ciclo estival, que, junto al cultivo, se encargarían de mantener altas la población de trips virulíferos, provocando ciclos secundarios de infección. Adicionalmente, muchos de ellos persisten en buenas condiciones hasta el otoño-comienzo de invierno, momento en el cual las plantas del cultivo dejan de ser atractivas, permitiendo que los vectores infectivos migren hacia ellos, y así mantener al virus y vector hasta la llegada de las malezas "puente" de invierno-primavera (Groves et al., 2002; Kahn et al., 2005).

A modo de ejemplo, Northfield et al. (2008) determinaron que la mayor proporción de trips en el norte del estado de Florida EE. UU. se encontraba en flores de Rubus cuneifolius y Trifolium repens en primavera, en Raphanus raphanistrum y Chenopodium ambrosioides en verano y en Solidago canadensis en otoño, señalando a $R$. raphanistrum y $S$. canadensis como vínculos potenciales del insecto entre estaciones.

En ciertas regiones existen plantas del cultivo todo el año, ya sean comerciales o espontáneas, lo cual, sumado a la preferencia del vector por ellas y a la ocurrencia de inviernos benignos, minimiza el papel de las malezas en la epidemiología de la enfermedad, tal como sucede en maní en Carolina del Norte (Culbreath y Srinivasan, 2011). Algo de esto podría ocurrir en el cultivo de morrón en invernáculo en la zona sur, donde muchas veces al final del ciclo se dejan los restos, se corta solamente la parte aérea de las plantas que luego rebrotan, o plantines espontáneos que nacen de frutos de descarte, que brindarían refugio a trips e inóculo para el próximo cultivo (Figura 43). 


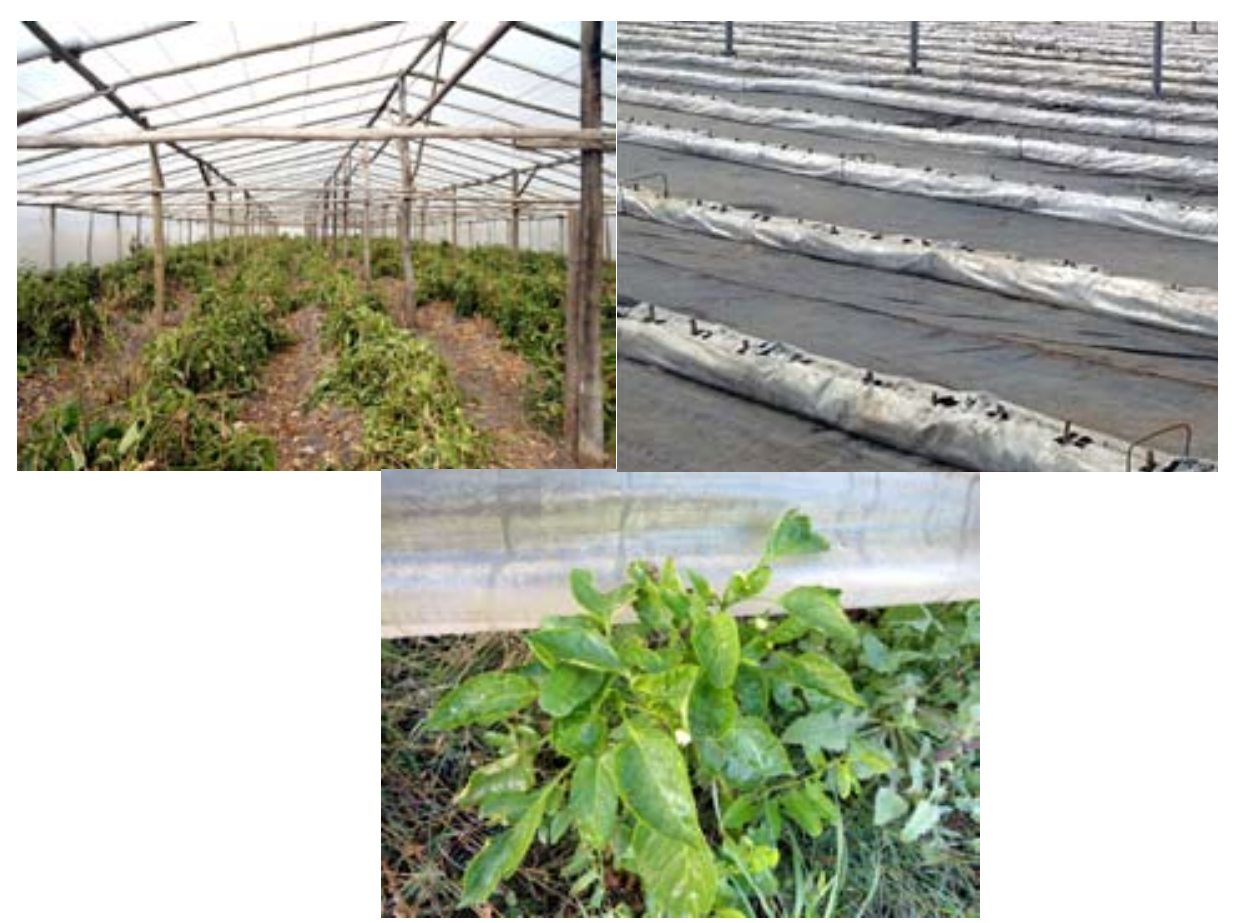

Figura 43. Presencia de plantas de un cultivo luego de su finalización de este. Arriba eliminación de la parte aérea (izquierda) dejando la subterránea (derecha) y plantas espontáneas de morrón originadas de frutos caídos (abajo). Fotos: D. Maeso

En el caso específico del cultivo de pimiento en invernáculo en Uruguay podríamos distinguir dos situaciones: el cultivo en la zona norte donde el ciclo cubre desde fin de verano a inicio de primavera y el cultivo en la zona sur cuyo ciclo es desde primavera a invierno. Los períodos sin cultivo comercial ocurren en época diferente, lo cual influye en la relación con los huéspedes alternativos. En la zona norte las fuentes de inóculo inicial y trips serán las malezas de primaveraverano, mientras que en el sur este papel lo desempeñan las malezas de invierno-primavera. La supervivencia de trips y enfermedad en el final del cultivo, específicamente para la zona sur será dada por las malezas que florecen en otoño-invierno. A esto debemos agregar que algunos huéspedes alternativos solamente permanecen dentro del invernáculo y otros afuera, exhibiendo diferente comportamiento y lugar en el ciclo epidemiológico. A continuación, analizaremos algunos casos concretos derivados de nuestros trabajos experimentales.

\section{Presencia de trips y orthotospovirus en malezas en invernáculos de la zona sur de Uruguay}

\section{1) Malezas hospederas de trips vectores asociadas a cultivos de morrón.}

Para determinar la secuencia de malezas asociadas a cultivos de morrón en invernáculos que pudieran tener influencia en la ocurrencia de peste negra se realizó el seguimiento semanal de ocho invernáculos en dos zonas de producción del departamento de Canelones (Arenales y Canelón Chico) durante setiembre 2017- setiembre 2019. Se registró la presencia de malezas en floración dentro y fuera de los invernaderos y la cantidad de trips en diez flores de cada una de las presentes en el momento de muestreo. 
El relevamiento fue dirigido a plantas de flores blancas, amarillas o celestes, dada la preferencia del insecto por esos colores. En total se realizaron 100 visitas y se registraron alrededor de 40 especies de plantas diferentes. Los trips se colectaron en una solución de alcohol, ácido acético y tritón, se contaron, y una fracción representativa fue identificada a nivel de especie en el laboratorio de Entomología de INIA Salto Grande. La identificación de las malezas observadas fue realizada por el Dr. Jorge Arboleya de INIA Las Brujas.

En los cuadros 6 y 7 se presentan las malezas encontradas con mayor frecuencia lvalores de presencia 3\% o superior en el total de especies observadas en alguna de las visitas en cada estación) en el interior (cuadro 6) y en el exterior (cuadro 7) de los invernáculos. En los cuadros 8 y 9 aparecen las que contribuían con la mayor proporción de trips dentro del total de trips encontrado en las flores de cada período. Como se puede apreciar, los registros dentro y fuera del invernadero fueron diferentes, tanto en especies vegetales como en su presencia en las estaciones. Algo para tener en cuenta en el análisis de la información es que no siempre las flores de las malezas predominantes son las que presentaban la mayor proporción de trips.

Otro aspecto para destacar de este estudio es la existencia de plantas cultivadas de albahaca y sandía dentro de algunos de los cultivos de morrón estudiados. No es algo común, pero la presencia de trips en sus flores, sumado a su mención como huéspedes de peste negra hacen poco recomendable esta práctica, a pesar de las razones muy respetables que tuvieron los productores para hacerlo.

Cuadro 6. Especies de malezas prevalentes en el interior de invernaderos de morrón del departamento de Canelones durante el período setiembre 2017-2019 (en porcentaje del total de especies encontradas)

\begin{tabular}{|c|c|c|c|c|}
\hline MALEZA & Primavera & Verano & Otoño & Invierno \\
\hline Cerraja (Sonchus oleraceus) & 9 & 6 & 14 & 15 \\
\hline Mostacilla (Raphistrum rugosum) & 7 & 7 & 7 & 6 \\
\hline Corregüela (Convolvulus arvensis) & 22 & 21 & 8 & 4 \\
\hline Albahaca silvestre (Galinsoga parviflora) & 1 & 5 & 6 & 8 \\
\hline Bledo (Amaranthus sp.) & 1 & 8 & 2 & 0 \\
\hline Yuyo colorado (Amaranthus quitensis) & 13 & 13 & 18 & 7 \\
\hline Verdolaga (Portulaca oleracea) & 12 & 10 & 2 & 0 \\
\hline Sandía (Citrullus lanatus) & 3 & 5 & 1 & 0 \\
\hline Tomatillo-hierba mora (Solanum americanum) & 0 & 2 & 3 & 7 \\
\hline Ortiga mansa (Lamium amplexicaule) & 0 & 1 & 5 & 9 \\
\hline Albahaca (Ocimum basilicum) & 3 & 4 & 5 & 0 \\
\hline Capiquí (Stellaria media) & 9 & 2 & 11 & 22 \\
\hline Bolsa de pastor (Capsella bursa-pastoris) & 0 & 1 & 1 & 7 \\
\hline Verbena violácea (Verbena sp.) & 1 & 1 & 0 & 7 \\
\hline Pega-pega (Picris echioides) & 2 & 3 & 3 & 3 \\
\hline
\end{tabular}

Promedio de un total de 50 visitas a ocho invernáculos del departamento de Canelones (setiembre 2017-2019), se promediaron los resultados de dos estaciones y se presentan las malezas que aparecieron con frecuencia mayor a $3 \%$ en alguna de las visitas en el período. 
Cuadro 7. Especies de malezas prevalentes en el exterior de invernaderos de morrón del departamento de Canelones durante el período setiembre 2017-2019 (en porcentaje del total de especies encontradas) ${ }^{1}$

\begin{tabular}{lcccc}
\hline MALEZA & Primavera & Verano & Otoño & Invierno \\
\hline Trébol blanco (Trifolium repens) & 19 & 13 & 0 & 13 \\
Cerraja (Sonchus oleraceus) & 9 & 9 & 12 & 11 \\
Mostacilla (Raphistrum rugosum) & 10 & 5 & 5 & 7 \\
Senecio (Senecio spp.) & 3 & 2 & 9 & 11 \\
Corregüela (Convolvulus arvensis) & 10 & 11 & 1 & 0 \\
Trébol rojo (Trifolium pratense) & 4 & 8 & 5 & 5 \\
Manzanilla (Matricaria spp.) & 8 & 2 & 1 & 2 \\
Albahaca silvestre (Galinsoga parviflora) & 1 & 2 & 6 & 2 \\
Yuyo colorado (Amaranthus quitensis) & 1 & 2 & 7 & 1 \\
Cardo negro (Cirsium spp.) & 2 & 2 & 1 & 2 \\
Alfalfa (Medicago sativa) & 1 & 3 & 1 & 7 \\
Tomatillo-hierba mora (Solanum americanum) & 1 & 1 & 9 & 4 \\
Ortiga mansa (Lamium amplexicaule) & 0 & 0 & 0 & 7 \\
Achicoria (Cichorium intybus) & 1 & 6 & 3 & 1 \\
Revientacaballos (Solanum sisymbriifolium) & 4 & 2 & 1 & 1 \\
\hline
\end{tabular}

Promedio de un total de 50 visitas a ocho invernáculos del departamento de Canelones (setiembre 2017-2019), se promediaron los resultados de dos estaciones y se presentan las malezas que aparecieron con frecuencia mayor a $3 \%$ en alguna de las visitas de cada período.

Cuadro 8. Contribución de las diferentes especies de malezas encontradas en el interior de invernaderos de morrón del departamento de Canelones al número total de trips determinado en flores en cada estación durante el período setiembre 2017-2019 (en porcentaje del total de individuos colectados en el período)'.

\begin{tabular}{lcccc}
\hline MALEZA & Primavera & Verano & Otoño & Invierno \\
\hline Cerraja (Sonchus oleraceus) & $0^{2}$ & 1 & 4 & 10 \\
Mostacilla (Raphistrum rugosum) & 40 & 30 & 27 & 6 \\
Corregüela (Convolvulus arvensis) & 10 & 11 & 1 & 0 \\
Albahaca silvestre (Galinsoga parviflora) & 0 & 1 & 2 & 6 \\
Senecio (Senecio sp.) & 3 & 1 & 1 & 1 \\
Yuyo colorado (Amaranthus quitensis) & 11 & 6 & 16 & 11 \\
Verdolaga (Portulaca oleracea) & 0 & 3 & 0 & 0 \\
Sandía (Citrullus lanatus) & 0 & 25 & 7 & 0 \\
Tomatillo-hierba mora (Solanum americanum) & 0 & 0 & 2 & 10 \\
Ortiga mansa (Lamium amplexicaule) & 0 & 0 & 1 & 16 \\
Albahaca (Ocimum basilicum) & 8 & 1 & 8 & 0 \\
Capiquí (Stellaria media) & 1 & 1 & 2 & 26 \\
Bolsa de pastor (Capsella bursa-pastoris) & 0 & 0 & 1 & 7 \\
Verbena violácea (Verbena sp.) & 2 & 7 & 0 & 0 \\
Pega-pega (Picris echioides) & 0 & 4 & 14 & 0 \\
\hline
\end{tabular}

1 Promedio de 50 visitas a ocho invernáculos del departamento de Canelones (setiembre 2017-2019), resultados promedio de dos estaciones y se presentan los registros de especies cuya contribución al total de trips colectados es $>3 \%$ en alguna fecha del periodo.

2 Porcentaje promedio del total de trips registrados en todas las flores examinadas en cada estación durante el periodo de estudio. 
Cuadro 9. Contribución de las diferentes especies de malezas encontradas en el exterior de invernaderos de morrón del departamento de Canelones al número total de trips determinado en flores en cada estación durante el período setiembre 2017-2019 (en porcentaje del total de individuos colectados en el período)'.

\begin{tabular}{|c|c|c|c|c|}
\hline MALEZA & Primavera & Verano & Otoño & Invierno \\
\hline Trébol blanco (Trifolium repens) & $14^{2}$ & 10 & 8 & 13 \\
\hline Cerraja (Sonchus oleraceus) & 2 & 3 & 4 & 7 \\
\hline Mostacilla (Raphistrum rugosum) & 22 & 11 & 12 & 25 \\
\hline Senecio (Senecio spp.) & 5 & 1 & 5 & 3 \\
\hline Corregüela (Convolvulus arvensis) & 4 & 4 & 1 & 0 \\
\hline Trébol rojo (Trifolium pratense) & 6 & 20 & 13 & 20 \\
\hline Manzanilla (Matricaria spp.) & 5 & 0 & 0 & 1 \\
\hline Albahaca silvestre (Galinsoga parviflora) & 1 & 0 & 1 & 0 \\
\hline Yuyo colorado (Amaranthus quitensis) & 1 & 3 & 10 & 1 \\
\hline Cardo negro (Cirsium spp.) & 5 & 6 & 5 & 3 \\
\hline Alfalfa (Medicago sativa) & 16 & 7 & 5 & 0 \\
\hline Tomatillo-hierba mora (Solanum americanum) & 0 & 0 & 3 & 0 \\
\hline Ortiga mansa (Lamium amplexicaule) & 0 & 0 & 1 & 3 \\
\hline Achicoria (Cichorium intybus) & 0 & 4 & 3 & 1 \\
\hline Revientacaballos (Solanum sisymbriifolium) & 2 & 2 & 1 & 0 \\
\hline Diente de león (Taraxacum officinale) & 0 & 1 & 2 & 2 \\
\hline Lotus (Lotus sp.) & 2 & 2 & 0 & 1 \\
\hline Rábano blanco (Raphanus raphanistrum) & 2 & 0 & 1 & 7 \\
\hline Capiquí (Stellaria media) & 0 & 0 & 0 & 6 \\
\hline Bolsa de pastor (Capsella bursa-pastoris) & 0 & 0 & 1 & 2 \\
\hline Verbena violácea (Verbena sp.) & 5 & 3 & 2 & 0 \\
\hline Pega-pega (Picris echioides) & 4 & 13 & 15 & 1 \\
\hline
\end{tabular}

1 Promedio de 50 visitas a ocho invernáculos del departamento de Canelones (setiembre 2017-2019), resultados promedio de dos estaciones y se presentan los registros de especies cuya contribución al total de trips colectados es $>3 \%$ en alguna fecha del periodo.

2 Porcentaje promedio del total de trips registrados en todas las flores examinadas en cada estación durante el periodo de estudio.

Tal como se describiera, el número de trips junto a la época de floración de las especies encontradas son importantes en definir su peso en la epidemiología de la enfermedad. Tomando la información de los cuadros anteriores, se elaboraron los diagramas de las Figuras 44 y 45 en los que se ilustra la superposición en el tiempo de la floración de los diferentes grupos de malezas y su aporte en vectores con relación al ciclo del cultivo. De esa forma, cerraja, capiquí, bolsa de pastor, albahaca silvestre, tomatillo, ortiga mansa, mostacilla, yuyo colorado y los tréboles blanco y rojo, por ser huéspedes de la enfermedad, presentar su floración en invierno y por su aporte en trips, tendrían potencialmente un importante papel de mantener vectores infectivos entre cultivos. 


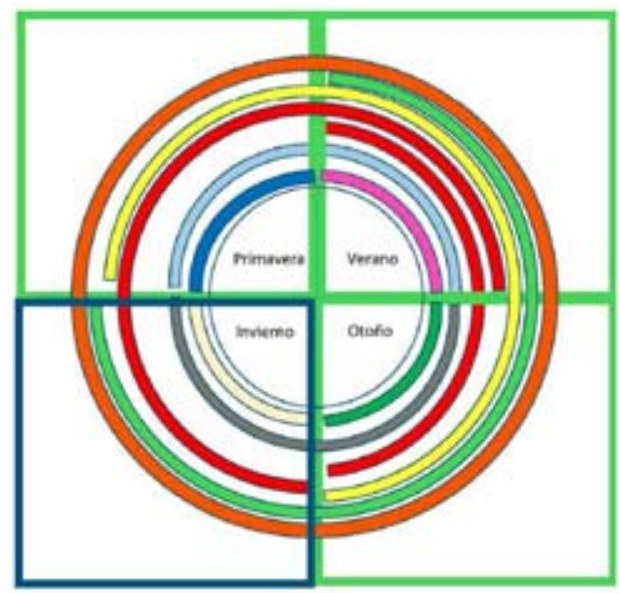

\begin{tabular}{|c|c|c|c|}
\hline & 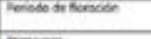 & 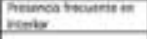 & 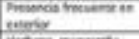 \\
\hline$=$ & movent & & vetan movers. \\
\hline m & honeveres & verainest & cosedt \\
\hline$\underline{E}$ & 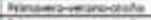 & Canged: & Fereters \\
\hline 世 & nimown & 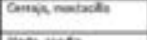 & Companateds \\
\hline & Wence & When, wines & Waras \\
\hline 므 & verounte & & consons: \\
\hline & 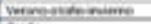 & sanmatanits & Detering: \\
\hline 口 & Cow & 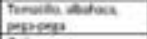 & 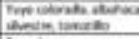 \\
\hline 늘 & Didermenn & onymers & Gimeris \\
\hline E & mines & 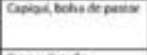 & 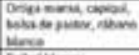 \\
\hline & 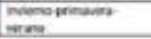 & forectorse: & Niberibines \\
\hline
\end{tabular}

Figura 44. Períodos de floración de las malezas prevalentes en el trabajo de seguimiento 2017-2019. Los cuadrados externos en verde corresponden a meses con presencia del cultivo, en azul al período sin cultivo.

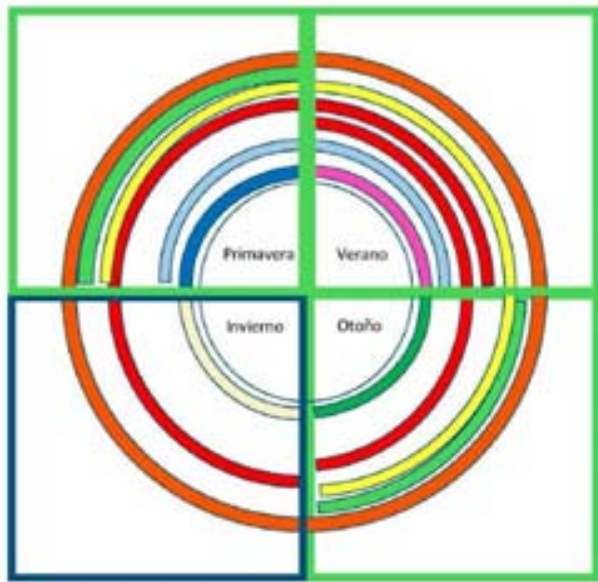

\begin{tabular}{|c|c|c|c|}
\hline & 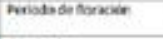 & 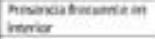 & 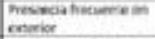 \\
\hline & Frimcers & & Mervildet veturs \\
\hline$\square$ & Priatemsomise & conity an & \\
\hline$\square$ & Trimentemstarodions & & AOI \\
\hline$\square$ & 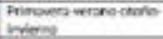 & 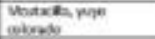 & 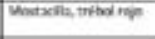 \\
\hline & Vinm & Wortem & \\
\hline & yerroveons & Wenti & 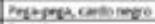 \\
\hline 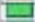 & 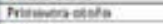 & Nothis: & Sereces \\
\hline$\square$ & Deto & Fobare & Tresectorats \\
\hline$\square$ & incense & 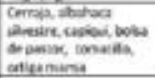 & 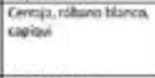 \\
\hline & 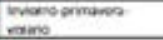 & & Tritei biance \\
\hline
\end{tabular}

Figura 45. Períodos de floración de las malezas prevalentes con mayor aporte de trips registradas en el trabajo de seguimiento 20172019. Los cuadrados externos en verde corresponden a meses con presencia del cultivo, en azul al período sin cultivo. 
En las Figuras 46 y 47 se muestran algunas de las malezas mencionadas, aclarando que se trató de una aproximación a su identificación y por lo tanto puede haber discrepancias en cuanto a la exactitud de la asignación de los nombres científicos.

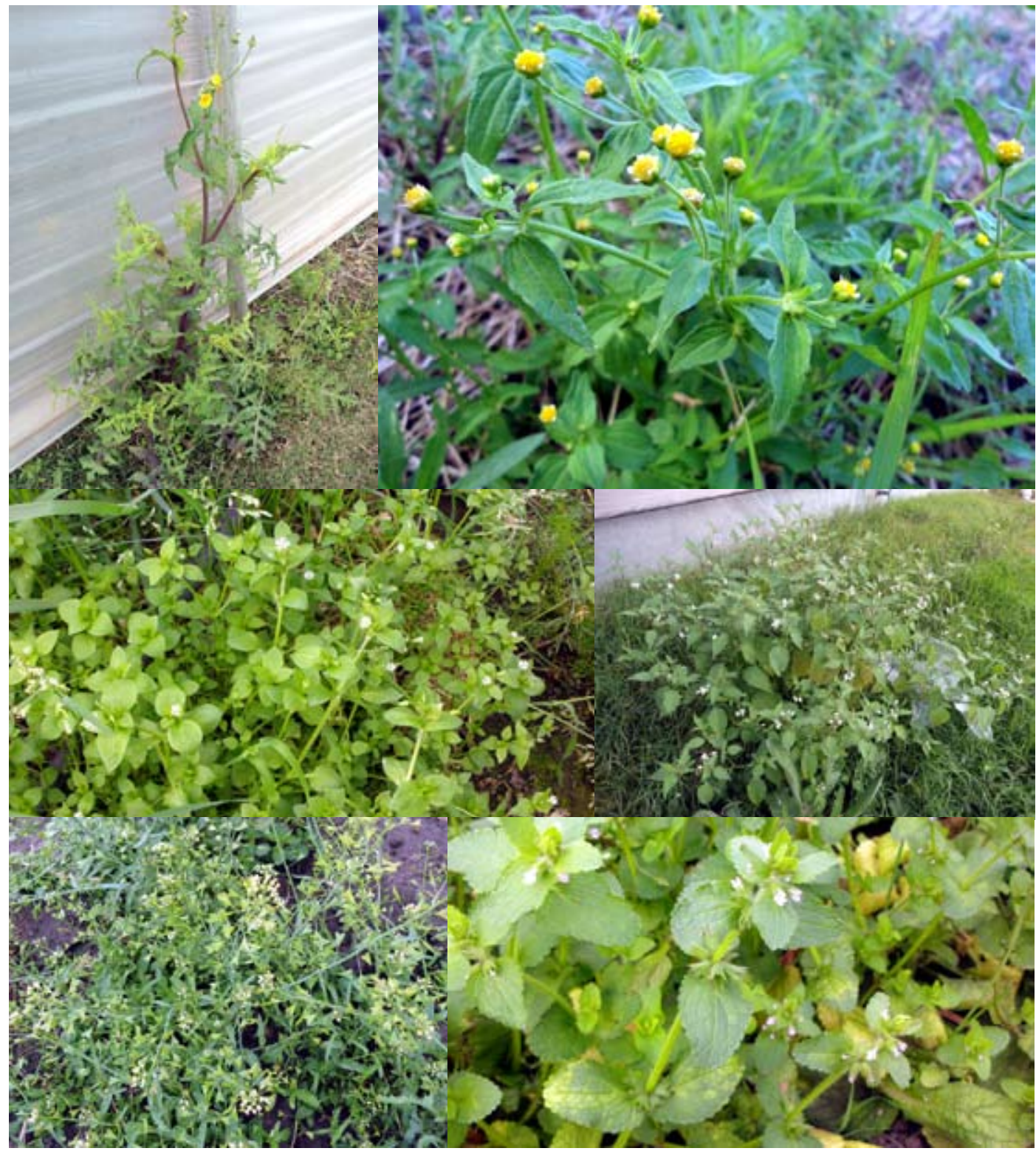

Figura 46. Principales malezas con presencia y hospedadoras de trips en invierno presentes fundamentalmente en el interior de los invernáculos durante el seguimiento 2017-2019. Arriba izquierda: cerraja, centro: albahaca silvestre, derecha: capiquí, abajo izquierda: tomatillo, centro: bolsa de pastor, derecha: ortiga mansa. Fotos: D. Maeso. 


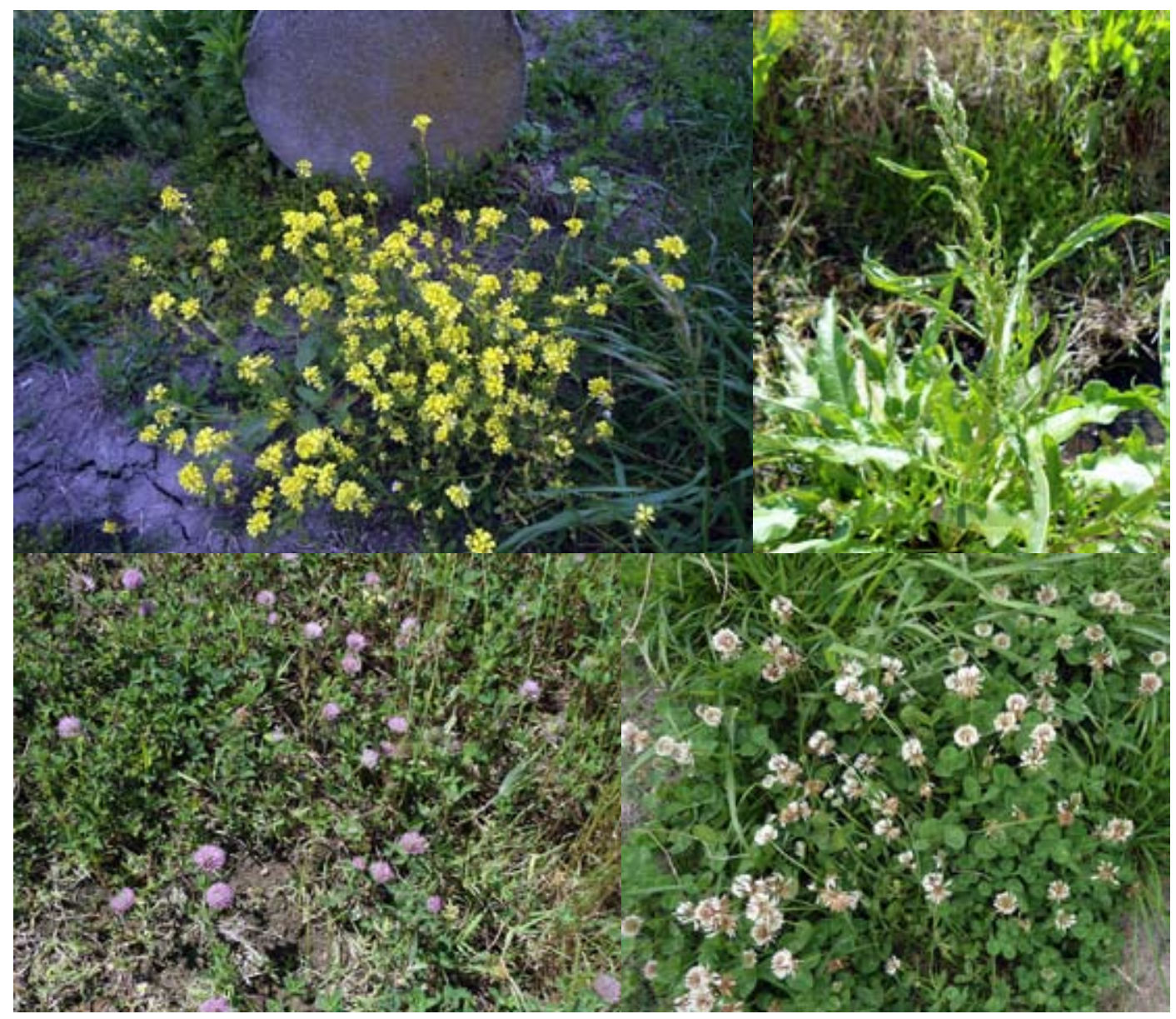

Figura 47. Principales malezas con presencia y hospedadoras de trips con floración en varias estaciones, invierno incluido, presentes durante el seguimiento 2017-2019. Arriba izquierda: mostacilla, derecha: yuyo colorado, abajo izquierda: trébol rojo, derecha trébol blanco. Fotos D. Maeso.

\section{2) Especies de trips presentes en las malezas relevadas}

En el cuadro 10 y la Figura 48 se presentan las especies de trips identificadas en las principales malezas encontradas en el relevamiento 2017-2019 asociadas a cultivos de morrón en invernáculo en el departamento de Canelones.

Como se mostró en la Figura 40, existe una tendencia estacional en la presencia de las tres especies vectores considerando a todas las malezas en su conjunto. Sin embargo, al analizarlas en forma individual vemos algunas preferencias. Por ejemplo T. tabaci es la única especie presente en senecio en verano-otoño-invierno; en cerraja y albahaca silvestre en primavera; en manzanilla, capiquí, albahaca y tomatillo en verano; en mostacilla en invierno, y en yuyo colorado en primavera-verano-invierno. Teniendo en cuenta que esta especie no es muy eficiente en la trasmisión de orthotospovirus, aporta un elemento para considerar en la valoración de estas malezas en el ciclo de la enfermedad. 
Por otra parte, F. occidentalis predomina en primavera en mostacilla y sandía; en verano en malva cimarrona, albahaca silvestre, cerraja y corregüela; en otoño en malva cimarrona, albahaca, albahaca silvestre, capiquí, pega-pega, tomatillo, cerraja y yuyo colorado; y en invierno en capiquí, tomatillo y cerraja. Siendo esta la especie predominante en flores de morrón y la principal trasmisora de TSWV, el virus prevalente en el cultivo, podemos suponer que algunos de estos huéspedes serán relevantes en el mantenimiento del vector en el periodo sin cultivo (malva cimarrona, capiquí, tomatillo, cerraja). F. schultzei fue encontrado en pocas oportunidades, solamente en mostacilla, malva cimarrona y tomatillo, fundamentalmente en verano y otoño, lo cual coincide con su presencia también en flores de morrón.

Cuadro 10. Especies de trips identificadas en algunas de las malezas registradas en el seguimiento 2017-2019 de los invernaderos según estación.

\begin{tabular}{|c|c|c|c|c|c|c|c|c|c|c|c|c|}
\hline \multirow{2}{*}{ Maleza } & \multicolumn{3}{|c|}{ Primavera } & \multicolumn{3}{|c|}{ Verano } & \multicolumn{3}{|c|}{ Otoño } & \multicolumn{3}{|c|}{ Invierno } \\
\hline & F.o & F.s. & T.t. & F.o. & F. s. & T. $t$. & F.o. & F.s. & T. $t$. & F.o. & F.s. & T. $t$. \\
\hline Cerraja (Sonchus oleraceus) & & & $100^{2}$ & 50 & & 50 & 50 & & 50 & 78 & & 22 \\
\hline Corregüela (Convolvulus arvensis) & & & & 50 & & 50 & & & & & & \\
\hline $\begin{array}{l}\text { Albahaca silvestre } \\
\text { (Galinsoga parviflora) }\end{array}$ & & & 100 & 50 & & 50 & 100 & & & & & \\
\hline Manzanilla (Matricaria sp.) & 25 & & 75 & & & 100 & & & & & & \\
\hline Mostacilla (Raphistrum rugosum) & 50 & & 50 & 11 & 16 & 73 & 43 & 7 & 50 & & & 100 \\
\hline Pega-pega (Picris echioides) & & & 100 & & & 100 & 63 & & 38 & & & \\
\hline $\begin{array}{l}\text { Tomatillo-hierba mora } \\
\text { (Solanum americanum) }\end{array}$ & & & & & & 100 & 67 & 17 & 17 & 100 & & \\
\hline Senecio (Senecio sp.) & & & & & & 100 & & & 100 & & & 100 \\
\hline Capiquí (Stellaria media) & & & & & & 100 & 80 & & 20 & 100 & & \\
\hline $\begin{array}{l}\text { Yuyo colorado } \\
\text { (Amaranthus quitensis) }\end{array}$ & 8 & & 92 & & & 100 & 62 & & 38 & & & 100 \\
\hline Albahaca (Ocimum basilicum) & 29 & & 71 & & & 100 & 100 & & & & & \\
\hline Sandía (Citrullus lanatus) & 50 & & 50 & & & & & & & & & \\
\hline Malva cimarrona (Anoda cristata) & & & & 71 & 29 & & 100 & & & & & \\
\hline
\end{tabular}

${ }^{1}$ F.oc. $=$ Frankliniella occidentalis; F.s. $=$ F. occidentalis; T.t. $=$ Thrips tabaci

${ }^{2}$ Se refiere al porcentaje de los insectos identificados en cada maleza en cada estación que correspondía a determinada especie. 


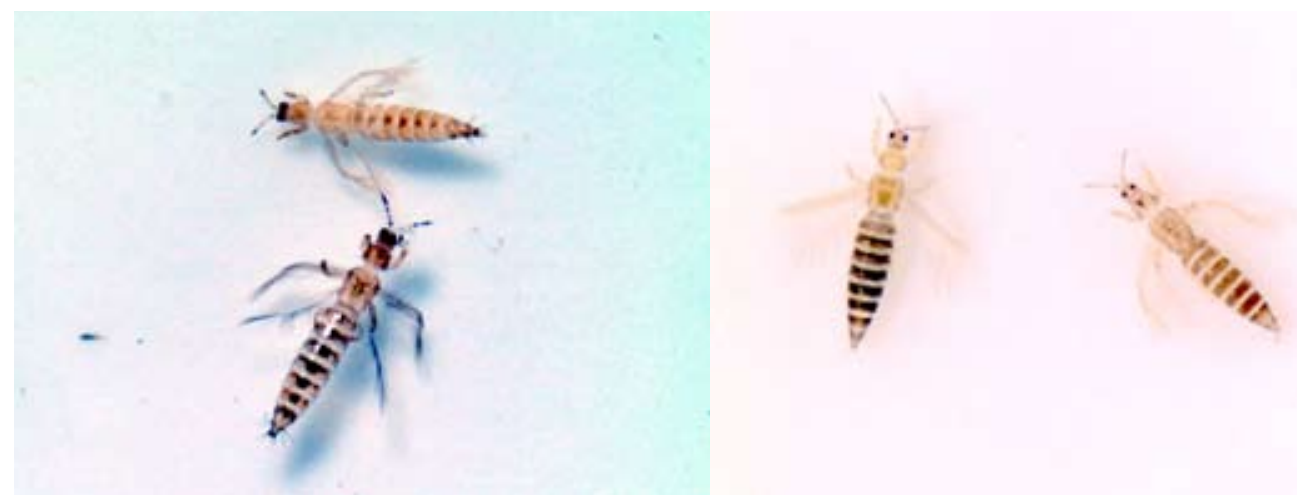

\section{aq actuHin}

Figura 48. Especies de trips identificadas en flores morrón y de malezas asociadas al cultivo. Izquierda: F. occidentalis, derecha: T. tabaci, abajo: F. schultzei. Fotos V. Galván.

\section{3) Determinación de la infección con orthotospovirus en malezas asociadas a cultivos de morrón en invernáculo.}

Durante un seguimiento realizado en un establecimiento de producción hortícola bajo invernáculo de la zona de Canelón Chico en los años 2011-2012 (Maeso et al, 2013; 2014; 2015), que se caracterizaba por presentar importantes y reiterados ataques de peste negra en morrón, se colectaron malezas asociadas al cultivo con síntomas atribuibles a la enfermedad. Las muestras fueron analizadas mediante la técnica de DAS-ELISA utilizando antisueros comerciales monoclonales (AGDIA Inc.; EE. UU.) para determinar si los síntomas podían ser asociados con la infección con Orthotospovirus, específicamente TSWV.

En el cuadro 11 se muestran los resultados de los análisis. TSWV fue detectado en plantas de corregüela, revientacaballos, tomatillo, cerraja, verdolaga, yuyo colorado, cardo negro, gamba rusa, ortiga mansa, malva cimarrona, senecio, y quiebra-arados. Esto coincide en su mayor parte con la determinación de trips vectores en flores realizada durante 20172019. Cabe destacar que en 2011 el muestreo fue dirigido a plantas con síntomas, pero probablemente muchos de los huéspedes alternativos podían haber sido asintomáticos. En ese sentido, al repetir el trabajo en la temporada 2013-2014, ante la ausencia de plantas de malezas con síntomas, se optó por analizar plantas asintomáticas (270) entre las cuales se detectó TSWV en dos plantas de corregüela colectadas el 25/11/2013 en el interior y el $16 / 12 / 2013$ en el exterior y en una de cerraja colectada el 28/10/2013 en el exterior del invernáculo. El ataque al cultivo fue muy reducido $<2 \%$ de plantas afectadas) y se registró a la semana de la detección del virus en las malezas (Maeso et al, 2013; 2014; 2015). 
Cuadro 11. Detección de orthotospovirus mediante DAS-ELISA en malezas con síntomas atribuibles a virosis asociadas a un cultivo de morrón en invernáculo en Canelón chico en el ciclo 2011-2012.

\begin{tabular}{|c|c|c|c|c|c|c|c|}
\hline \multirow[b]{2}{*}{ Nombre común } & \multirow[b]{2}{*}{ Especie } & \multicolumn{2}{|c|}{ Número de plantas con } & \multirow{2}{*}{$\begin{array}{c}\text { Porcentaje } \\
\text { con } \\
\text { detección } \\
(\%)\end{array}$} & \multicolumn{3}{|c|}{ Período de detección } \\
\hline & & Síntomas & Detección & & $\begin{array}{l}\text { Primavera } \\
\text { (2011)1 }\end{array}$ & $\begin{array}{c}\text { Verano } \\
\text { (2011- } \\
\text { 2012) }\end{array}$ & $\begin{array}{l}\text { Otoño } \\
\text { (2012) }\end{array}$ \\
\hline Corregüela & $\begin{array}{l}\text { Convolvulus } \\
\text { arvensis }\end{array}$ & 28 & 1 & 4 & & 1 & \\
\hline Revientacaballos & $\begin{array}{l}\text { Solanum } \\
\text { sisymbrifolium }\end{array}$ & 30 & 3 & 10 & 2 & 1 & \\
\hline Tomatillo & $\begin{array}{l}\text { Solanum } \\
\text { americanum }\end{array}$ & 32 & 15 & 47 & 3 & 7 & 5 \\
\hline Cerraja & $\begin{array}{l}\text { Sonchus } \\
\text { oleraceus }\end{array}$ & 24 & 3 & 13 & 2 & 1 & \\
\hline Quinoa & Chenopodium sp. & 16 & 0 & 0 & & & \\
\hline Verdolaga & $\begin{array}{l}\text { Portulaca } \\
\text { oleracea }\end{array}$ & 25 & 4 & 16 & 3 & 1 & \\
\hline Chamico & Datura sp. & 2 & 0 & 0 & & & \\
\hline Yuyo colorado & Amaranthus sp. & 30 & 1 & 3 & & 1 & \\
\hline Cardo negro & Cirsium vulgare & 4 & 4 & 100 & 1 & 2 & 1 \\
\hline Gamba rusa & $\begin{array}{l}\text { Alternanthera } \\
\text { philoxeroides }\end{array}$ & 11 & 1 & 9 & 1 & & \\
\hline Falsa ortiga & Stachys arvensis & 11 & 5 & 45 & 2 & 1 & 2 \\
\hline Malva cimarrona & Anoda cristata & 22 & 5 & 23 & 2 & 3 & \\
\hline Trébol rojo & Trifolium pratense & 4 & 0 & 0 & & & \\
\hline Aguaymanto & Physalis sp. & 6 & 0 & 0 & & & \\
\hline Senecio & Senecio sp. & 4 & 3 & 75 & & 3 & \\
\hline Diente de león & $\begin{array}{l}\text { Taraxacum } \\
\text { officinale }\end{array}$ & 3 & 0 & 0 & & & \\
\hline $\begin{array}{l}\text { Amor del } \\
\text { hortelano }\end{array}$ & $\begin{array}{l}\text { Galinsoga } \\
\text { parviflora }\end{array}$ & 1 & 0 & 0 & & & \\
\hline Quiebra arados & Sida rhombifolia & 4 & 1 & 25 & & 1 & \\
\hline Total & & 257 & 46 & 18 & & & \\
\hline
\end{tabular}

${ }^{1}$ Las fechas de detección fueron: primavera 17/11, 15/12 y 8/12/2011; verano 21/12/2011, 5/1, 19/1, 2/2, 16/2 y 14/3/2012; otoño $30 / 3,9 / 4$ y $26 / 4 / 2012$.

TSWV fue detectado en fechas fuera del ciclo del cultivo, al comienzo o luego de finalizado, al igual que ocurrió con la presencia del vector (Figura 49). Este hecho refuerza la importancia de estas malezas para cerrar el ciclo de la enfermedad. 


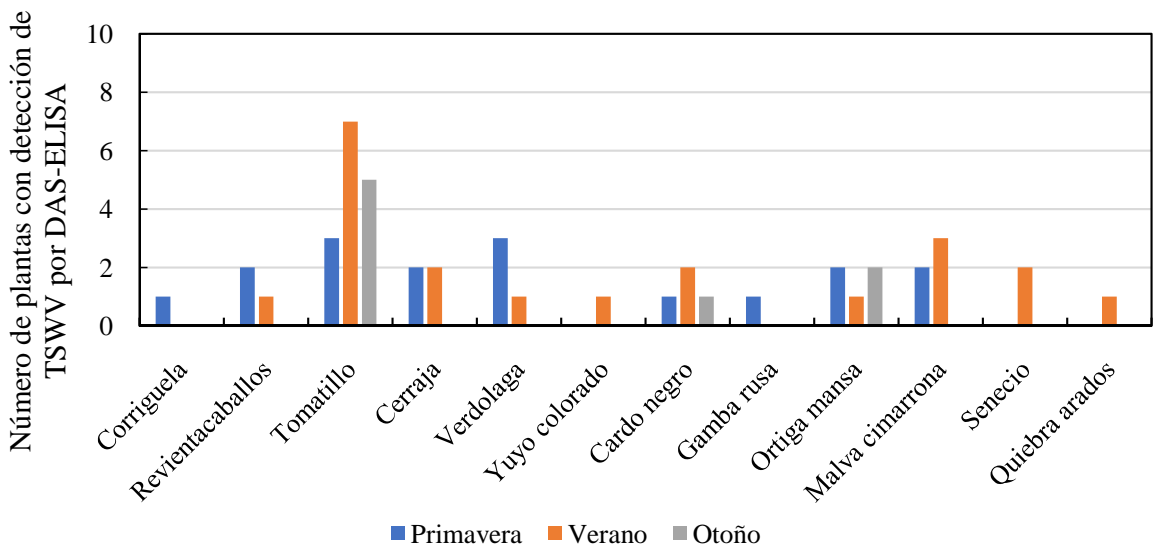

Figura 49. Número de plantas de malezas asociadas a un cultivo de morrón en invernadero en Canelón Chico en las que se detectó TSWV por DAS-ELISA según estaciones.

En la figura 50 el número de plantas con detección de TSWV es discriminado según estuvieran dentro o fuera del invernáculo.

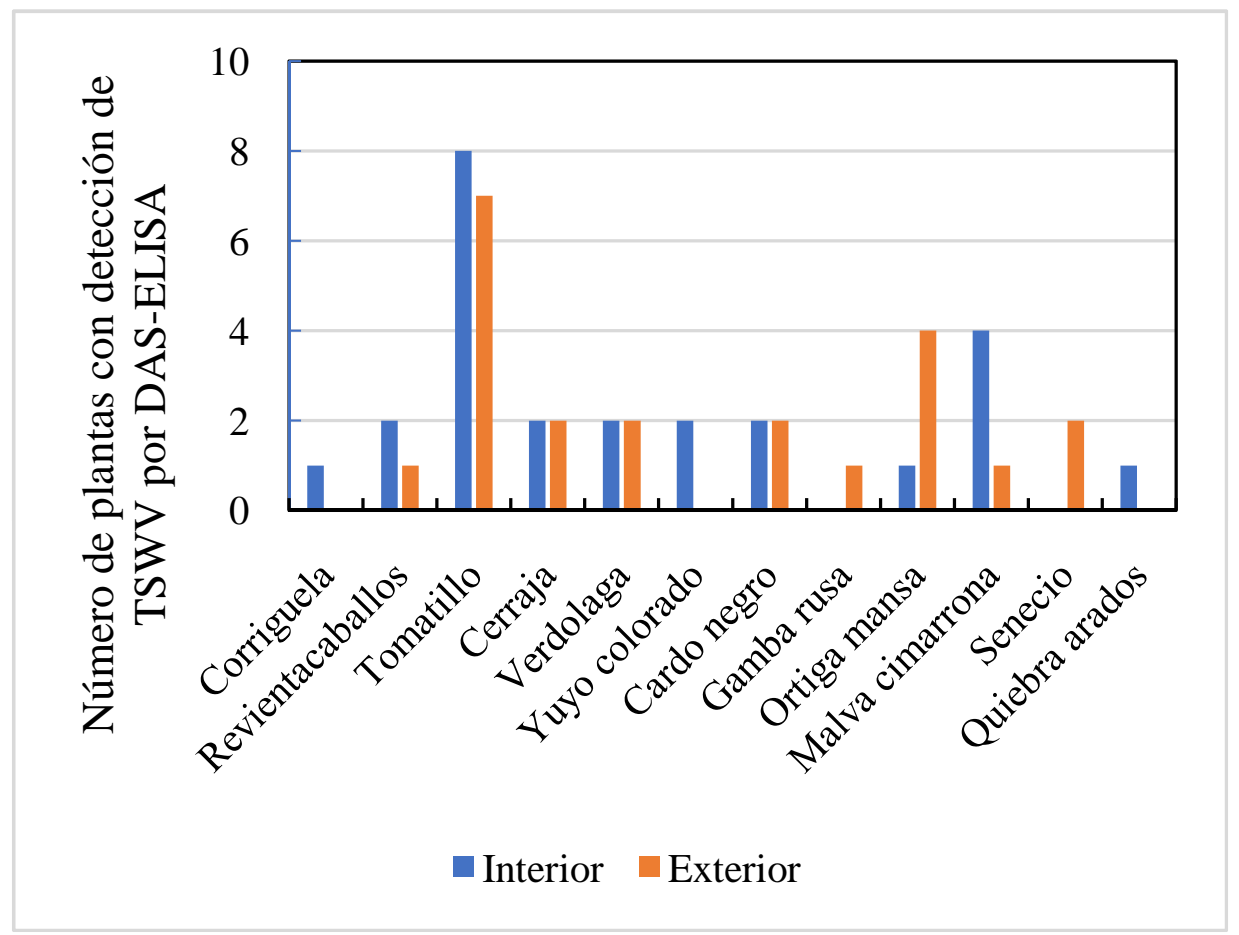

Figura 50. Localización de las malezas donde se detectó TSWV durante el ciclo 2011-2012 en un cultivo de morrón en invernáculo en Canelón Chico. 
En la Figura 51 se muestran síntomas observados en algunas de las malezas en las que se detectó TSWV en este estudio.

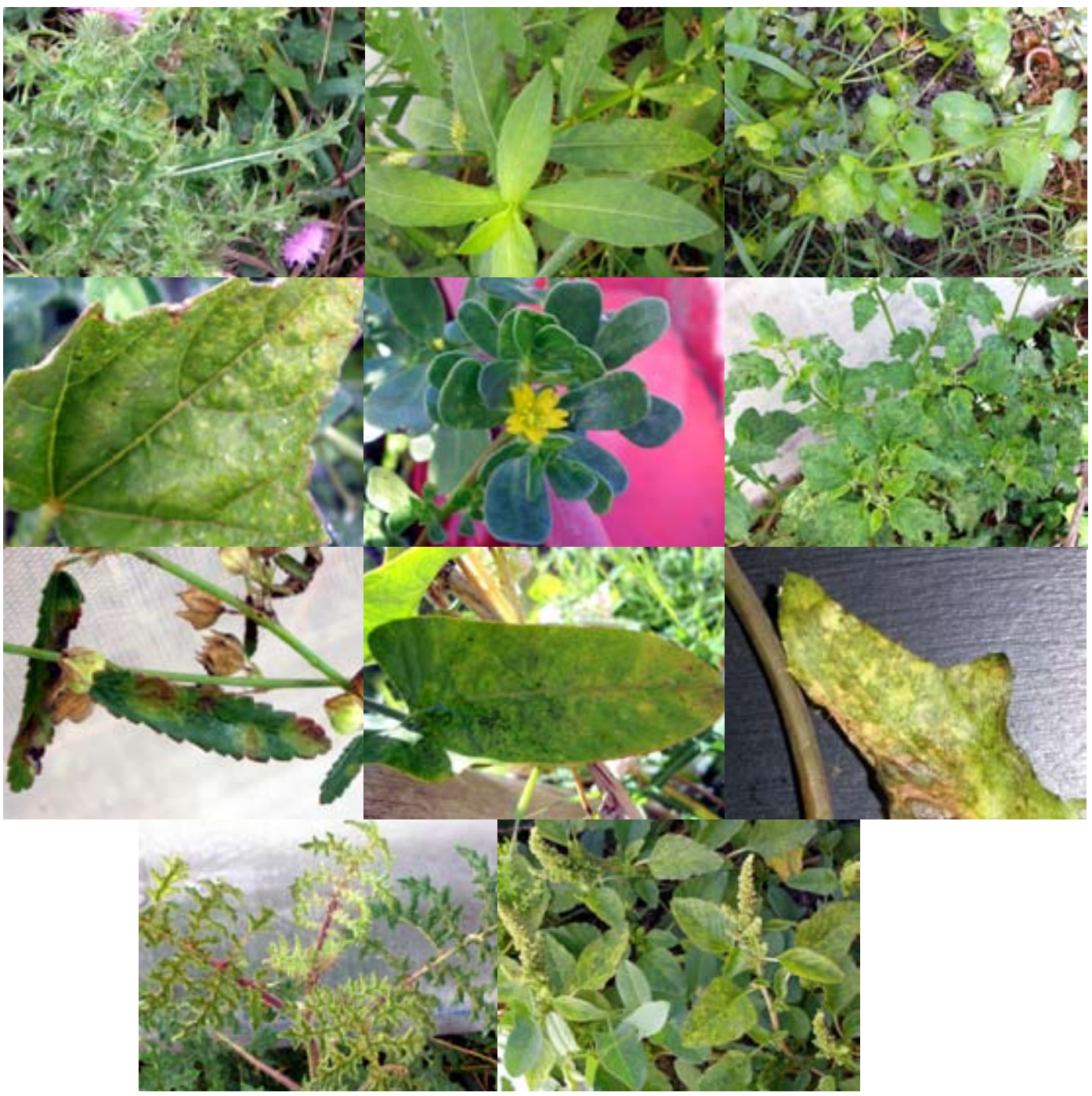

Figura 51. Síntomas observados en algunas de las malezas asociadas con un cultivo de morrón en invernadero en las que se detectó TSWV mediante DAS-ELISA. Primera fila izquierda: cardo negro, centro: gamba rusa, derecha: ortiga mansa, segunda fila izquierda: malva cimarrona, centro: verdolaga, derecha: tomatillo, tercera fila izquierda: quiebra arados, centro: corregüela, derecha: cerraja, cuarta fila izquierda: revienta caballos, centro: yuyo colorado. Fotos D. Maeso.

De acuerdo con lo presentado en los numerales anteriores, a modo de resumen se podría suponer que, considerando la presencia entre estaciones de cultivo, capacidad de albergar F. occidentalis y/o detección de TSWV en nuestros estudios, las principales malezas a tomar en cuenta en el ciclo de peste negra en morrón en la zona sur serían: cerraja, albahaca silvestre, capiquí, bolsa de pastor, tomatillo, ortiga mansa, rábano y trébol blanco. Si bien no observamos síntomas o detección en algunas de ellas, han sido mencionadas como huéspedes de TSWV en la bibliografía (cuadro 4). 
En la figura 52 se muestran algunos ejemplos de la abundancia de estos huéspedes en floración durante invierno afuera de invernáculos sin cultivo, los cuales permanecen hasta la nueva estación, dependiendo de cuan intensas sean las heladas (Figura 53) por lo que a partir de ese momento toma relevancia la permanencia de malezas en flor en el interior. En la figura 54 se aprecian algunos ejemplos de malezas dentro de los invernáculos sin cultivo, principalmente en las paredes y los postes, aún después de realizar la preparación del suelo para la nueva plantación.

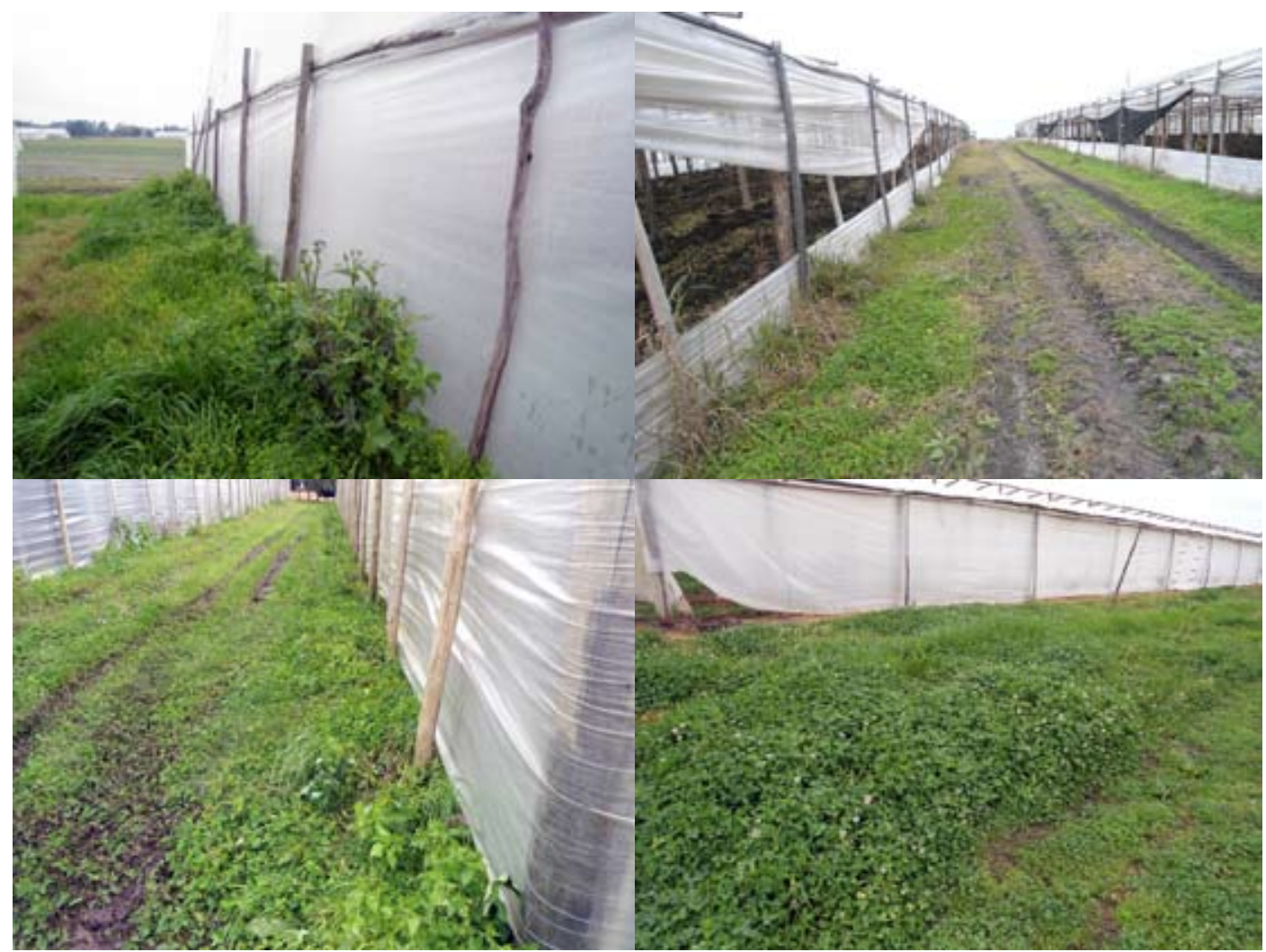

Figura 52. Algunos ejemplos de la presencia de malezas en floración afuera de invernáculos vacíos durante invierno. Fotos $D$. Maeso

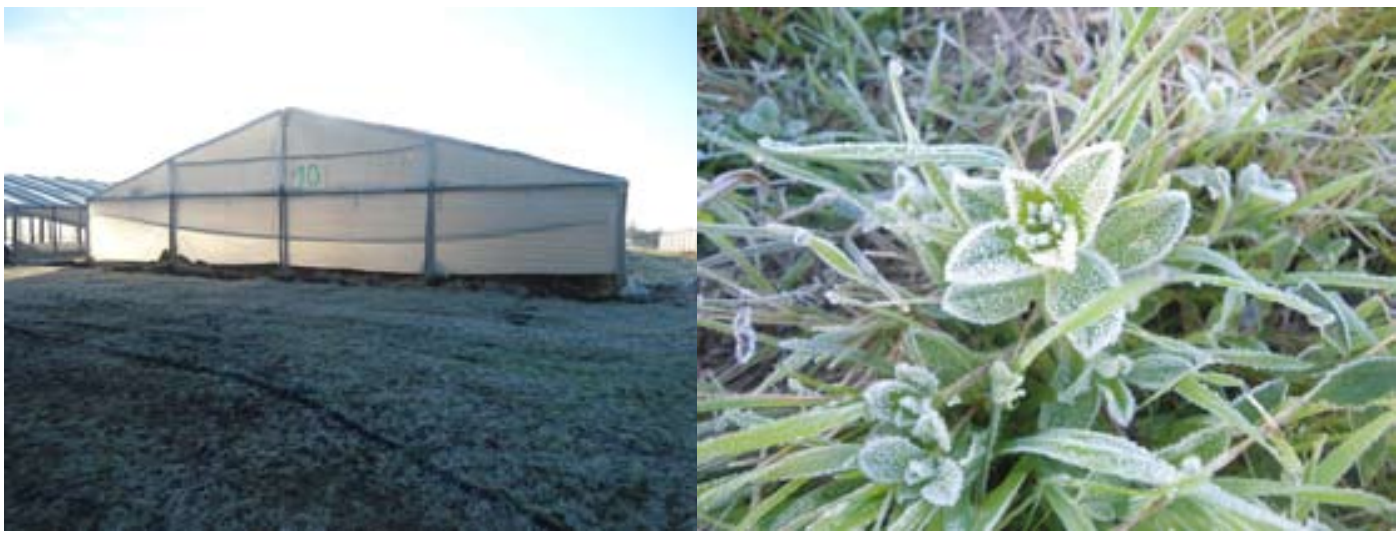

Figura 53. Efecto de las heladas sobre las malezas en el exterior de los invernáculos. Fotos D. Maeso 


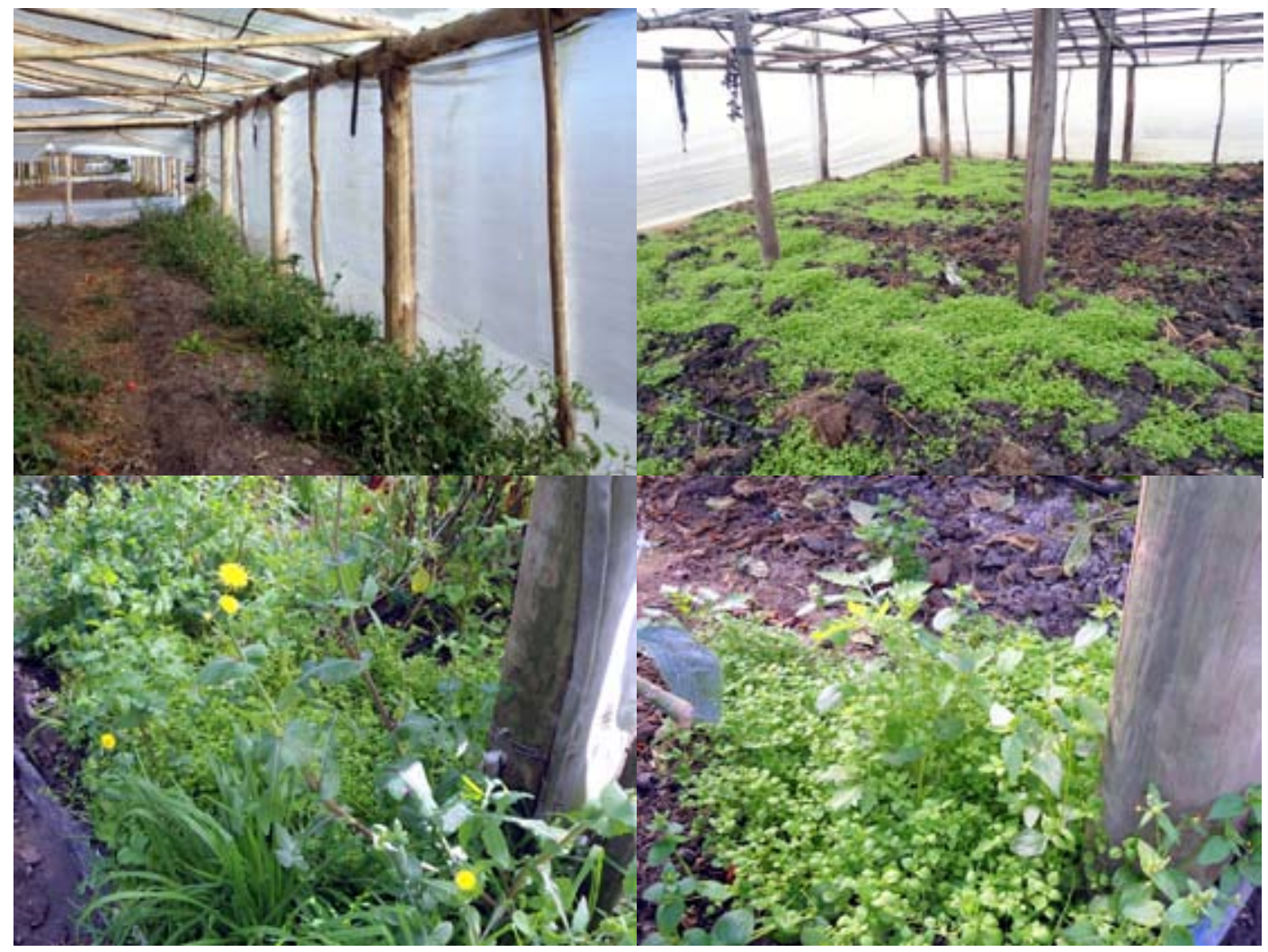

Figura 54. Presencia de malezas en invierno adentro de los invernáculos sin cultivo. Fotos D. Maeso

\section{EPIDEMIOLOGÍA}

\section{Características del ciclo de peste negra de tomate y morrón}

El desarrollo de la enfermedad durante la temporada ha sido estudiado en muchos cultivos anuales (maní, tabaco, tomate, morrón). La mayor parte de los trabajos de seguimiento espacio-temporal reportan que el proceso es principalmente de característica monocíclica, es decir una única trasmisión a partir de fuentes externas con vectores que llegan al cultivo hacia fines de primavera, o que emergen de pupas remanentes de la temporada previa, siendo poco relevante la diseminación secundaria dentro del cultivo (Stewart et al., 1989; Camann et al., 1995; Chellemi et al., 1994; Cho et al., 1995; Johnson et al., 1995; Toapanta et al., 1996; Gitaitis et al., 1998; Groves et al., 2001a; 2001b; Culbreath et al., 2003; 2011; Coutts et al., 2004; Jones, 2004; Pappu et al., 2009).

Esta afirmación está basada en que en la mayoría de los casos se observan gradientes pronunciados en la proporción de plantas enfermas de acuerdo con la distancia a las fuentes externas de infección, con agregación cercana al inoculo inicial y escasa aparición posterior de agregados de plantas enfermas derivadas de algunos pocos eventos policíclicos (Gitaitis et al., 1998; Groves et al., 2001; Coutts et al., 2004). La magnitud del foco y su posición respecto a la dirección del viento influye sobre el gradiente, la dirección y la dimensión del contagio (Gitaitis et al., 1998, Groves, 2001; Coutts, 2004). 
La explicación para este comportamiento es que, previo a la trasmisión, como ya se dijo en párrafos anteriores, los adultos deben adquirir al virus como larva, replicarlo, empupar, lo cual requiere alrededor de tres semanas y ese proceso se cumpliría en las plantas huéspedes del inóculo primario. Luego los adultos deben emigrar a plantas sanas, que pueden ser del cultivo o de huéspedes intermedios. Si bien la trasmisión es rápida, se estima que todo el proceso insume bastante tiempo y no puede repetirse varias veces en un ciclo de cultivo (Moritz et al., 2004). Para que ocurran ciclos secundarios los adultos de la primera migración en un primer paso deben infectar plantas en el cultivo. Luego, establecer su progenie en ellas, las larvas adquirir el patógeno de las nuevas plantas infectadas y luego abandonarlas como adultos, lo cual, como vimos lleva como mínimo tres semanas.

Si la planta huésped no estimula la multiplicación del vector, solamente ocurrirá una infección primaria. Si en cambio es apropiada para el vector, para que haya trasmisión secundaria luego de establecer su progenie, debe suceder algo que haga que los adultos infectados migren a nuevas plantas. Esto ocurre cuando la planta deja de ser apetecible, por causas propias (senescencia) o por factores externos (erradicación, aplicación de insecticidas, manipulación de follaje, etc.). El tomate no es un huésped reproductivo destacado para $F$. occidentalis (Funderburk, 2009), pero el morrón sí, por lo que sería más propenso a recibir ciclos secundarios (van den Meiracker y Ramakers, 1991 citados por Reitz, 2015).

Los casos en los que la infección secundaria reviste mayor gravedad se producirían en cultivos de larga duración (p.ej. tomate y el morrón), con una alta proporción de plantas enfermas derivadas de la infección primaria y/o con malezas sensibles o plantas espontáneas infectadas lo cual facilita la ocurrencia de los procesos policíclicos posteriores que derivan en una gran incidencia final de la enfermedad (Coutts et al., 2004; Jones, 2004).

Los plantines infectados en almácigos, tubérculos, bulbos o rizomas infectados y las plantas enfermas en el cultivo también actúan como fuentes de inóculo internas al cultivo para establecer ciclos secundarios (Wilson, 1998; Jones 2004).

Entre los factores que hacen que una fuente de inóculo externa sea relevante se pueden mencionar el tipo (cultivo, restos vegetales, plantas espontáneas), la dimensión (tanto en cantidad como de su magnitud infectival, la duración de su presencia, la distancia y orientación frente a vientos predominantes, la existencia o no de obstáculos (como cortinas rompevientos o plantas no huéspedes), condiciones externas favorables (riego, clima benigno), las especies de vectores predominantes y su relación con éstos (Jones, 2004).

Algunos aspectos del vector y del cultivo susceptible también influyen en la magnitud del ataque. Respecto al vector, como vimos, son relevantes la especie, el momento del ciclo en que arriba al cultivo, y su abundancia. En cuanto al cultivo, influirán su susceptibilidad, ya sea por la especie botánica en sí, por las características del cultivar comercial utilizado (resistencia, tolerancia, ciclo), la densidad de plantación, el diseño de las filas respecto a la fuente primaria, la protección con mallas o barreras físicas o vivas, si el suelo está cubierto, así como los tratamientos o medidas de manejo empleadas (Jones, 2004). 
Específicamente para cultivos protegidos y almácigos, Jones (2004) identifica algunos factores adicionales como la mayor susceptibilidad de los estados juveniles del huésped, la plantación sucesiva de cultivos sensibles (p. ej. lechuga), las temperaturas internas de los invernáculos que favorezcan la presencia del vector y de huéspedes alternativos todo el año y las medidas preventivas que se apliquen (mallas anti-trips, plásticos que absorben UV u otras).

Durante uno de los múltiples seguimientos de la evolución de ataques en invernáculos que hemos realizado, pudimos comprobar, en otoño 2001 en la zona de Arenales, departamento de Canelones, cómo un cultivo lechuga trasplantado a los pocos días de uno de tomate cultivar Valeria que presentaba un $70 \%$ de plantas enfermas y convivió con sus restos, desarrolló la enfermedad a los pocos días (Figura 55). En la Figura 56 se puede apreciar claramente cómo la enfermedad evolucionó a partir de la infección del cultivo de tomate precedente ya que, luego del brote inicial, el número de plantas de lechuga enfermas no aumentó significativamente en el tiempo.

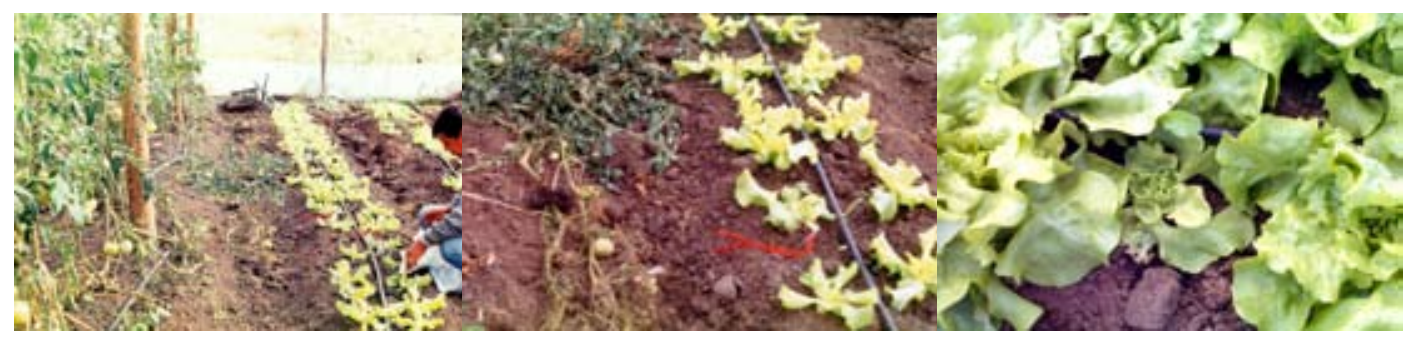

Figura 55. Cultivo de lechuga trasplantado al lado de un cultivo de tomate con una incidencia alta de peste negra en un invernadero de la zona de Arenales, departamento de Canelones que desarrolló la enfermedad a los pocos días. Fotos D. Maeso.

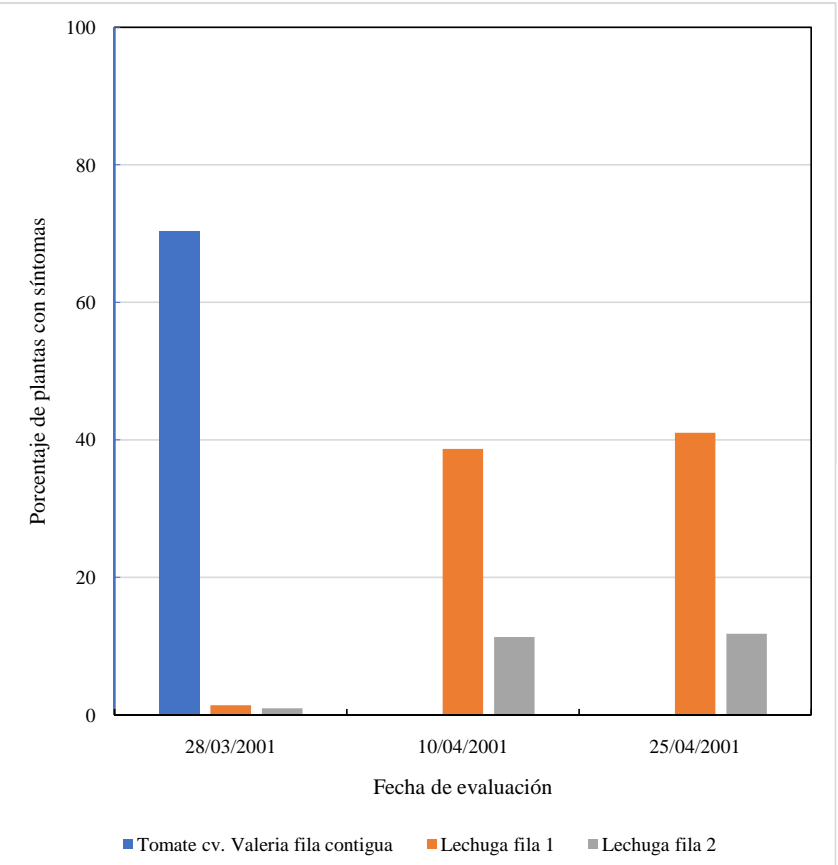

Figura 56. Evolución del porcentaje de plantas de lechuga con peste negra trasplantadas luego de un cultivo de tomate de la variedad Valeria con $70 \%$ de ataque de la enfermedad. La fila 1 de lechuga correspondía a la más cercana a las plantas de tomate remanentes. 
Esto da indicios de la trasmisión por migración de vectores infectivos desde un cultivo a otro.

Otra experiencia en la que se observa claramente la asociación del avance de un ataque de peste negra con un foco primario es lo observado en un cultivo de morrón en invernáculo en la zona de Canelón Chico durante 2018 (Figura 57). En ese trabajo se registró la evolución del porcentaje de plantas enfermas en ocho filas a partir de la fila cercana a la doble puerta y a la pared del invernáculo. Se revisaron en total 1080 plantas. En la figura 58 se aprecia la evolución en el tiempo y cómo la mayor incidencia se registró en la fila más cercana a la pared.

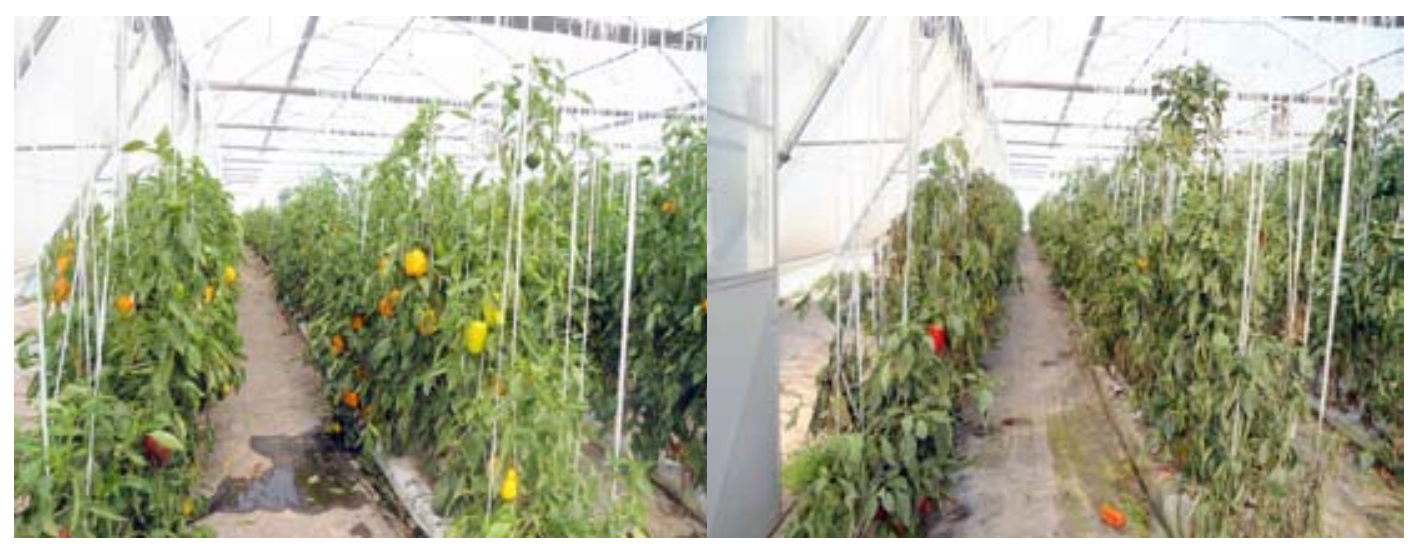

Figura 57. Detalle del ataque de peste negra en las dos filas contiguas a la pared exterior en un invernadero de Canelón Chico durante 2018. Izquierda marzo, derecha junio. Fotos D. Maeso

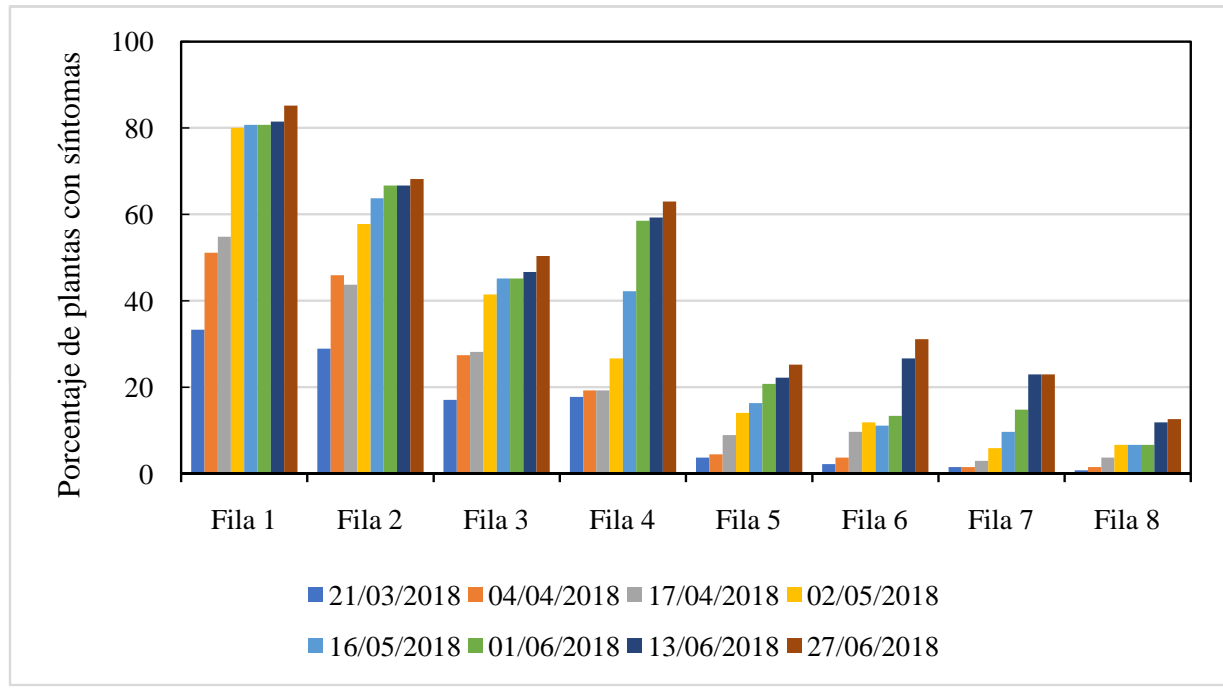

Figura 58. Incidencia de peste negra en un cultivo de morrón durante 2018 en un invernáculo en Canelón Chico. La fila 1 fue la contigua a la doble puerta y a la pared externa. 
Un análisis en conjunto de los registros de la evolución del número de plantas con la enfermedad en tomate y morrón en algunos de nuestros trabajos experimentales nos indica que, en algunos casos los ataques de peste negra se comportaron como procesos monocíclicos y en otros como policíclicos.

En los cuadros 12 y 13 se muestran los resultados de algunos de los análisis. Se realizaron análisis de regresión de la evolución en el tiempo de los valores de incidencia transformados según los modelos monocíclico $(\ln (1 /(1-x)))$ o policíclico $(\ln (x /(1-x)))$. En morrón en la temporada 2011-2012 en la que se alcanzaron los porcentajes de plantas con síntomas elevados, los coeficientes $r^{2}$ más altos indicarían que el proceso fue policíclico, o sea con transmisión secundaria dentro del cultivo, mientras que, en la temporada siguiente, con valores de la enfermedad bajos sería principalmente monocíclico ltransmisión inicial desde fuente de inóculo primarial. Esta información coincide con lo encontrado por van den Meiracker y Ramakers, 1991 (citados por Reitz, 2015) quienes expresan que como el cultivo de morrón es muy preferido por el vector es más propenso a producir múltiples procesos de trasmisión secundarios.

Cuadro 12. Información para el análisis del ataque de peste negra a dos cultivos de morrón en invernáculos de Canelón Chico en 2011-12 y 2012-13.

\begin{tabular}{|c|c|c|c|c|}
\hline & \multicolumn{2}{|c|}{$2011-2012$} & \multicolumn{2}{|c|}{$2012-2013$} \\
\hline & Sin malla & Con malla & Sin malla & Con malla \\
\hline \multicolumn{5}{|l|}{ Fecha de: } \\
\hline Trasplante & \multicolumn{2}{|c|}{$21 / 11 / 2011$} & \multicolumn{2}{|c|}{$11 / 10 / 2012$} \\
\hline Inicio de síntomas & \multicolumn{2}{|c|}{$15 / 12 / 2011$} & $14 / 12 / 2012$ & $5 / 11 / 2012$ \\
\hline Máximo sintomas² & \multicolumn{2}{|c|}{$26 / 1 / 2012$} & $14 / 1 / 2013$ & $3 / 12 / 2012$ \\
\hline $\begin{array}{l}\text { Porcentaje final de plantas } \\
\text { con síntomas }\end{array}$ & 99 & 65 & 9 & 7 \\
\hline $\begin{array}{l}\text { Coeficiente } r^{2} \text { (modelo } \\
\text { policíclico) }\end{array}$ & 0,93 & 0,95 & 0,22 & 0,40 \\
\hline $\begin{array}{l}\text { Coeficiente } r^{2} \text { (modelo } \\
\text { monocíclico) }\end{array}$ & 0,87 & 0,81 & 0,88 & 0,60 \\
\hline $\begin{array}{l}\text { Número de plantas } \\
\text { examinadas }\end{array}$ & 100 & 100 & 141 & 141 \\
\hline
\end{tabular}

${ }^{1}$ Los cultivares en 2011-2012 fueron Yatasto y Troyano, mientras que en 2012-2013 se agregó Kaima.

${ }^{2}$ Fecha en que se registró el mayor aumento en el número de plantas con síntomas

Como vemos en el cuadro 13 en los cultivos de tomate estudiados la enfermedad se comportó principalmente en forma monocíclica, o sea un solo proceso de infección sin reinfecciones internas. Esto coincide con lo reportado por Funderburk (2009) que menciona que tomate no es un huésped preferido por el vector. 
Cuadro 13. Información para el análisis del ataque de peste negra en ocho cultivos de tomate evaluados en el período $1998-2005$.

\begin{tabular}{|c|c|c|c|c|c|c|c|c|}
\hline & $1998-99$ & 1999 & $1999-2000$ & $\begin{array}{c}2000- \\
2001\end{array}$ & $\begin{array}{c}2000- \\
2001\end{array}$ & $\begin{array}{c}2003- \\
2004\end{array}$ & 2004 & $2004-2005$ \\
\hline Cultivar & \multicolumn{3}{|c|}{ Dominique } & & Valeria & \multicolumn{2}{|c|}{ Coloso } & Nemonetta \\
\hline \multicolumn{9}{|l|}{ Fecha de: } \\
\hline Trasplante & Nov-98 & Abr-99 & Oct-99 & set-00 & set-00 & Oct-03 & Feb-04 & Nov-04 \\
\hline $\begin{array}{l}\text { Inicio de } \\
\text { síntomas }\end{array}$ & 1/12/1998 & 28/4/1999 & 10/11/1999 & $4 / 10 / 2000$ & $31 / 1 / 2001$ & $9 / 1 / 2004$ & $18 / 2 / 2003$ & $11 / 1 / 2005$ \\
\hline $\begin{array}{l}\text { Incremento } \\
\text { máximo } \\
\text { sintomas }{ }^{1}\end{array}$ & 29/1/1999 & 25/5/1999 & $25 / 1 / 2000$ & $2 / 11 / 2000$ & $28 / 3 / 2000$ & $16 / 1 / 2004$ & $16 / 4 / 2004$ & $3 / 3 / 2005$ \\
\hline $\begin{array}{l}\text { Porcentaje } \\
\text { final de } \\
\text { plantas con } \\
\text { síntomas }\end{array}$ & 33 & 73 & 69 & 38 & 67 & 3 & 17 & 15 \\
\hline $\begin{array}{l}\text { Coeficiente } \mathrm{r}^{2} \\
\text { (modelo } \\
\text { policíclico) }\end{array}$ & 0,72 & 0,36 & 0,22 & 0,46 & 0,84 & 0,49 & 0,87 & 0,36 \\
\hline $\begin{array}{l}\text { Coeficiente } r^{2} \\
\text { (modelo } \\
\text { monocíclico) }\end{array}$ & 0,81 & 0,92 & 0,90 & 0,46 & 0,92 & 0,85 & 0,81 & 0,92 \\
\hline Localización & \multicolumn{4}{|c|}{ INIA Las Brujas } & Arenales & \multicolumn{3}{|c|}{ INIA Las Brujas } \\
\hline $\begin{array}{l}\text { Número de } \\
\text { plantas } \\
\text { examinadas }\end{array}$ & 30 & 30 & 30 & 30 & 158 & 100 & 100 & 100 \\
\hline
\end{tabular}

${ }^{1}$ Fecha en que se registró el mayor aumento en el número de plantas con síntomas

El patrón de las plantas enfermas en el cultivo trasplantado nos puede insinuar el origen de la infección. Si estas se agrupan en la periferia del invernadero, seguramente se trate de infecciones provenientes de fuentes externas. Si la proporción de plantas afectadas es grande y no sigue el patrón anterior, seguramente se trate de una infección en la etapa de almácigo. La tercera alternativa, ocurre cuando el cultivo anterior tuvo la enfermedad y la infección proviene de los adultos emergentes de pupas del ciclo previo. En este caso la disposición y magnitud de la reinfección generalmente esté asociada a lo que ocurrió la temporada anterior.

Según nuestra experiencia en el seguimiento del desarrollo de la enfermedad en cultivos de la zona sur podemos encontrar ambos casos, cultivos en los que la enfermedad está restringida a focos, generalmente en el borde de la plantación o que están distribuidos en todo el cultivo, (Figuras 59 y 60), lo cual, como ya vimos, muchas veces está relacionado a la característica del proceso (policíclico o monocíclico). 


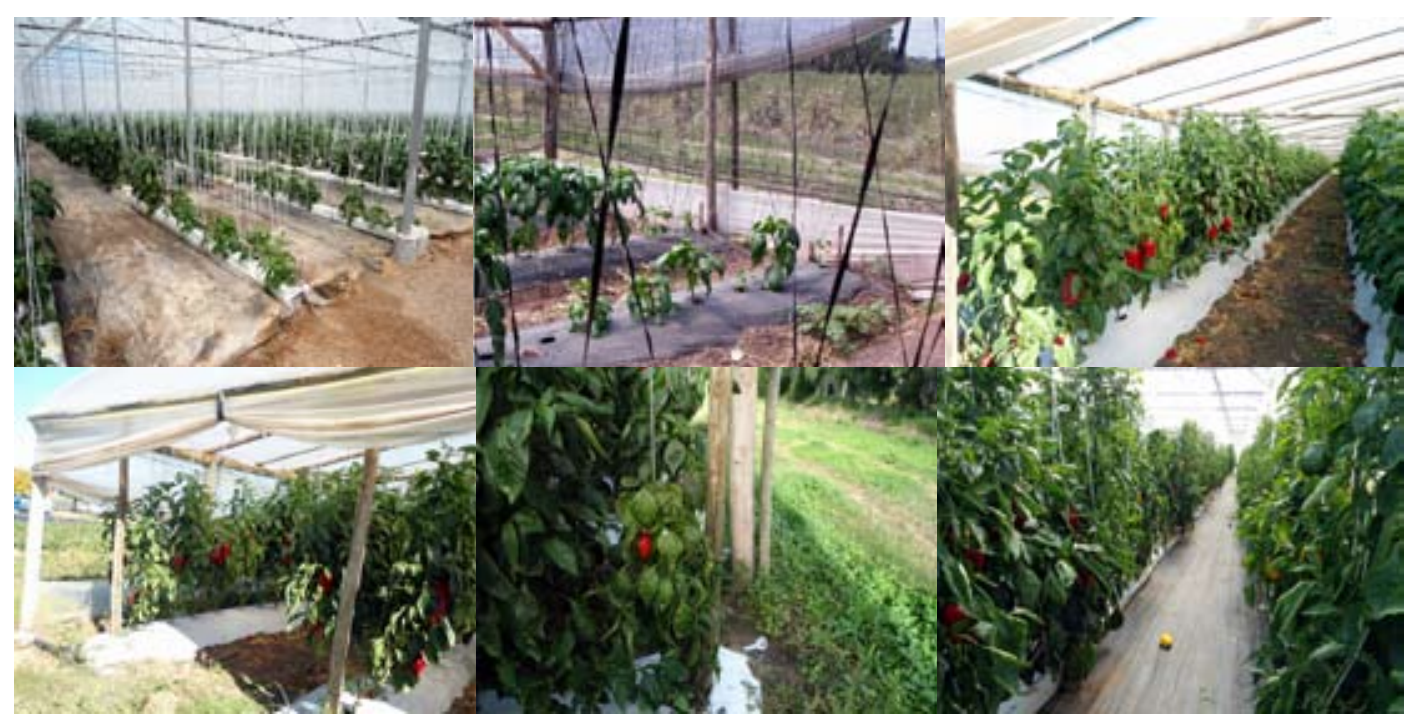

Figura 59. Ataques de peste negra en morrón en forma de focos, algunos reducidos y otros que abarcan varias filas del cultivo. Fotos D. Maeso.

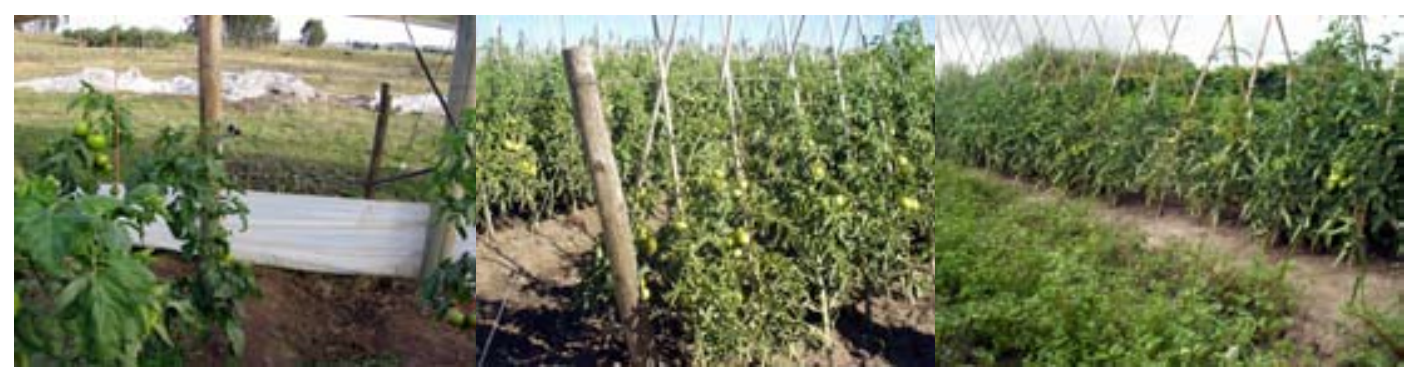

Figura 60. Focos de plantas con peste negra en tomate en bordes del cultivo. Fotos D. Maeso

\section{Papel del vector en el ciclo epidemiológico}

Para describir el papel del vector en el ciclo epidemiológico de la peste negra, nos basaremos en los resultados de trabajos experimentales de seguimiento que hemos realizado durante varios años, en los cuales analizaremos su comportamiento en diferentes momentos y etapas del cultivo y nos ayudaran a comprender cómo se desarrollan los eventos en nuestras condiciones.

\section{a) Origen de la migración inicial de vectores al cultivo.}

Como ya se mencionó, la infección inicial a los cultivos trasplantados en primavera-fin de invierno en invernáculos de la zona sur puede originarse de la migración vectores adultos infectivos desde el exterior que permanecieron en hospederos alternativos infectados, o del interior (cuadros 8,9 y 11 y figuras 46,47 y 50). En este último caso, además de los vectores que continuaron su ciclo en huéspedes alternativos dentro del invernáculo, se agregan los adultos infectivos que emergen de las pupas generadas en el cultivo previo. 


\section{Migración desde el exterior.}

En la Figura 61 se muestran algunos ejemplos de la evolución durante invierno-primavera de las capturas de trips adultos en trampas amarillas pegajosas ubicadas en las paredes exteriores de invernáculos con cultivos de morrón del departamento de Canelones. Dada la gran cantidad de datos que se dispone, solamente presentaremos como ejemplo los seguimientos 2011-2014 en un predio de Canelón Chico (Maeso et al., 2013; 2014; 2015) y 20172019 de un total de nueve cultivos, cuatro en Canelón chico y cinco del NE del departamento de Canelones (datos no publicados).

Para el análisis se consideró el período 1/6-30/9 como fechas frecuentes de finalización e inicio de cultivos. Si bien los valores de individuos capturados por día (total observado en la trampa dividido el período en que estuvo expuestal son bajos, se colectaron trips en las trampas pegajosas del exterior durante todo el período sin cultivo, y, salvo en 2012, generalmente los valores se incrementan hacia la fecha de trasplante de los cultivos.
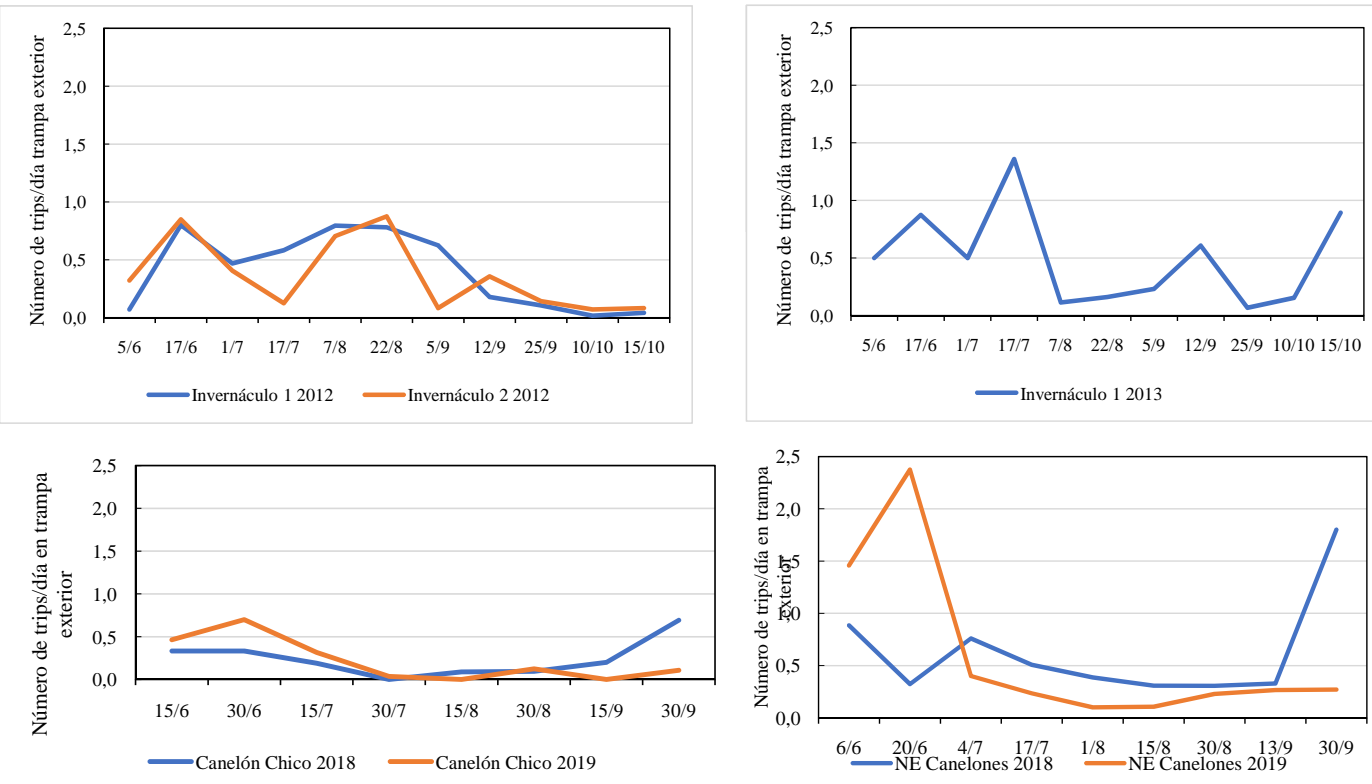

Figura 61. Evolución de las capturas de trips (en número de trips/día) en trampas amarillas pegajosas colocadas en las paredes externas de invernáculos dedicados a la plantación de morrón durante el período sin cultivo. Arriba: trampas en invernaderos de Canelón Chico (2012 y2013). Abajo: promedio de trampas colocadas en dos zonas de producción Canelón Chico (cuatro invernáculos) y Noreste de Canelones (cinco invernáculos), 2018 y 2019. 
Dado que en estos trabajos también se colectaba el número de adultos en trampas colocadas en el interior de los invernáculos, se realizó un análisis de correlación y regresión entre las capturas dentro y fuera de los invernáculos encontrándose correlación estadísticamente significativa entre el número total de las capturas en el exterior y en el interior en las tres temporadas analizadas. Esto, sumado a que en la mayoría de los casos las capturas en el exterior comenzaban antes que en el interior, nos permite suponer la existencia de migración de vectores hacia el cultivo, que, si son portadores de virus, influirá en el desarrollo de la enfermedad. En la Figura 62 se muestran las gráficas correspondientes a esos valores y en la Figura 63 las derivadas de su análisis de regresión.
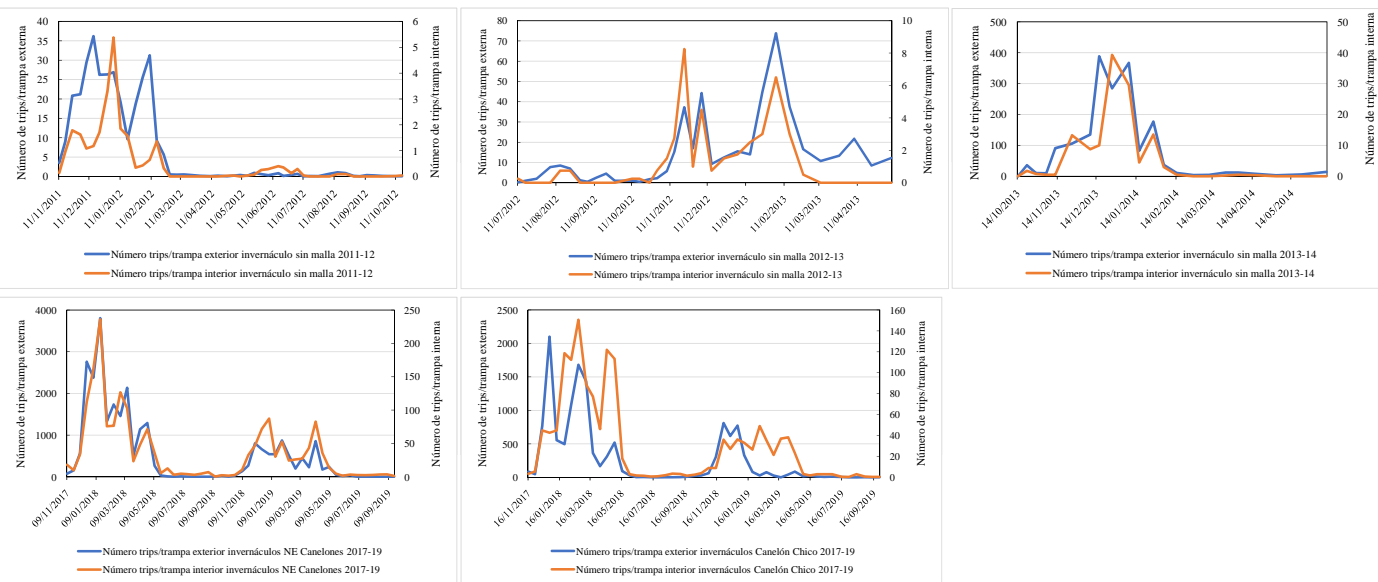

Figura 62. Evolución de las capturas de trips en trampas pegajosas amarillas colocadas en el exterior e interior de invernáculos dedicados al cultivo de morrón. Arriba: capturas del período 2011-2014 de un invernáculo sin malla perimetral en Canelón Chico. Abajo: izquierda capturas en el período 2017-2019 promedio de valores de cinco invernáculos del Noreste del departamento de Canelones, derecha capturas en el mismo período en cuatro invernáculos en Canelón Chico.
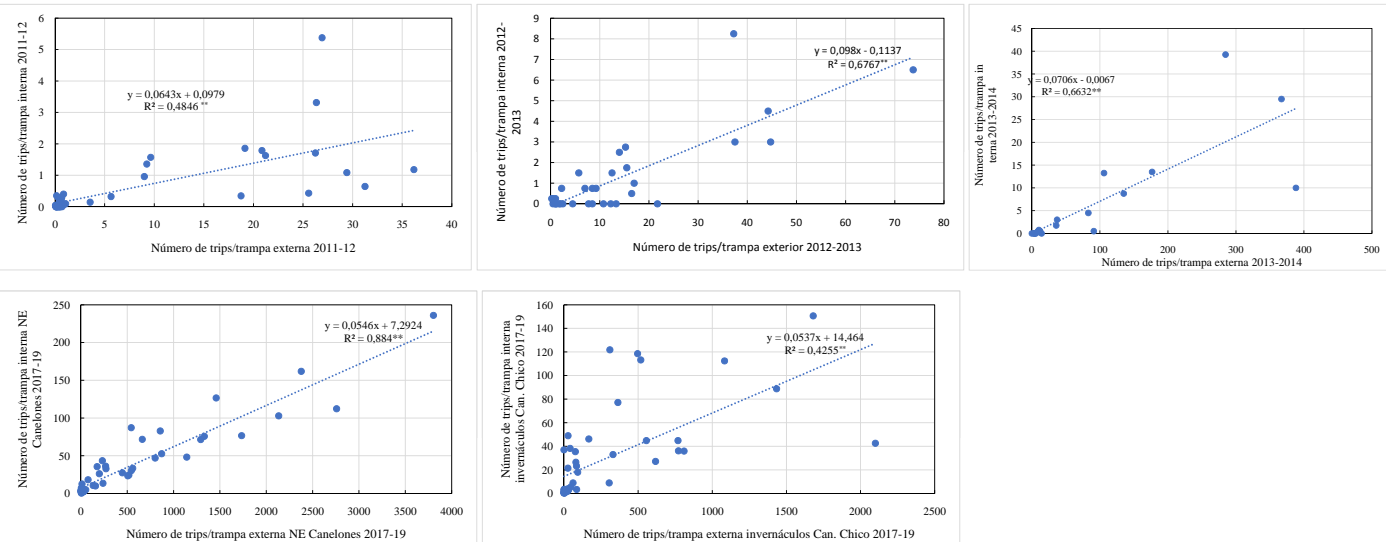

Figura 63. Rectas de regresión y coeficientes de correlación resultado del análisis estadístico de la relación entre los valores de capturas en trampas externas e internas presentados en la Figura 62. Arriba: valores de trampas externas e internas en un invernáculo en Canelón Chico. Abajo: izquierda valores promedio de cinco invernáculos del Noreste del departamento de Canelones, derecha capturas en el mismo período en cuatro invernáculos en Canelón Chico. 
De acuerdo con lo anterior se puede afirmar que el número de trips existentes en el exterior de los invernáculos tiene gran influencia en la presencia en el interior, por lo que los cultivos estarían permanentemente sujetos a la migración de adultos desde las inmediaciones.

Dado que $F$. occidentalis no presenta diapausa obligada por temperatura o por cantidad de horas de luz, tiene la capacidad de estar activo durante todo el año y su comportamiento dependerá de las condiciones ambientales (Ishida et al., 2003). Al aumentar las temperaturas en la primavera y morir las malezas invernales, los vectores adultos migran a los cultivos de tomate y morrón. La migración hacia el cultivo, la dispersión dentro de éste, el movimiento sobre una planta, la dinámica poblacional en su globalidad y como efecto indirecto, la magnitud de un ataque de peste negra, estarán muy influenciados por factores ambientales.

Se han realizado varios estudios con la finalidad de predecir estos fenómenos relacionándolos con variables climáticas, principalmente temperatura y lluvia. Se han determinado umbrales de temperatura asociados con la actividad del vector que difieren entre las especies y el sistema estudiado. Lowry et al. (1992) reportaron un umbral de temperatura mínima de $10,5^{\circ} \mathrm{C}$ para $F$. fusca y de $6,5^{\circ} \mathrm{C}$ para $F$. occidentalis, mientras que Mac Donald et al. (1998) utilizaron $7,9^{\circ} \mathrm{C}$ para esta última especie. Con esos valores se han calculado los "grados día" acumulados, o sea la acumulación de los valores promedios diarios que superan al umbral, los cuales pueden ser usados para definir el comienzo de determinada actividad en el ciclo del vector. Así Mac Donald et al. (1998) indican que para que F. occidentalis cumpla un ciclo de vida completo se necesita acumular 268 grados día por encima de $7,9^{\circ} \mathrm{C}$.

Sobre esta base se han realizado varios estudios en los que se asocia la acumulación de grados días con eventos del vector y del cultivo (primer trampeo, migración, emergencia). En general se acepta que la baja precipitación y temperaturas entre $20-24^{\circ} \mathrm{C}$ en primavera favorecen la migración de adultos, mientras que temperaturas bajas y lluvias frecuentes la reducen (Cho et al., 1987; Olatinwo et al., 2008). Morsello et al. (2008) encontraron una correlación positiva entre el número de individuos de $F$. fusca y T. tabaci capturados en trampas amarillas pegajosas en primavera, al comienzo de los cultivos, con la acumulación de grados día y el número de días con lluvia y una correlación negativa con la cantidad de precipitación acumulada en invierno-primavera.

Tomando en cuenta lo anterior se calcularon modelos predictivos de la enfermedad en maní y tabaco en base a la precipitación acumulada, número de días con lluvia, evapotranspiración y la temperatura en primavera temprana junto a aspectos específicos de cultivos tales como fecha de plantación y antecedentes que son de gran ayuda para definir acciones de manejo (Olatinwo et al., 2008, 2009, 2010; Cullbreath et al., 2011).

Morsello y Kennedy $(2009 ; 2010)$ encontraron que las diferencias en la cantidad de grados días acumulados en invierno-primavera y la cantidad de lluvia acumulada explicarían las diferencias en ataques de peste negra en tabaco. Las bajas temperaturas y la lluvia abundante disminuirían la trasmisión por efectos negativos directamente sobre el vector en sus huéspedes alternativos, enfatizando que el efecto prejudicial de la lluvia puede persistir por 5-6 semanas. 
Chappel et al. (2013) profundizaron en el tema ajustando un modelo en el cual consideran como factores de riesgo la ocurrencia de un ataque importante en la temporada previa seguido de un invierno moderado y húmedo que favorezca el solapamiento del final del ciclo del cultivo y de las malezas de verano-otoño con las malezas de invierno, así como la abundancia de estas. Por otra parte, agregan el efecto de las temperaturas favorables y pocas precipitaciones en primavera como promotores de la trasmisión al cultivo.

Buscando conocer si existía una relación con los parámetros climáticos externos que nos indicara el comienzo de la migración de trips hacia los cultivos realizamos un análisis similar con los datos de captura de trips durante invierno-primavera (junio a setiembre) en trampas amarillas ubicadas en el exterior de invernáculos de morrón en cuatro temporadas $(2012,2013,2018$ y 2019). En la Figura 64 se presentan los valores de capturas totales acumulados (promedio de todos los cultivos evaluados en cada temporada) y los datos climáticos correspondientes de las cuatro temporadas (registros de la casilla meteorológica de INIA Las Brujas). Con esos valores se realizó un análisis de regresión múltiple logística escalonada ("stepwise") contra los valores de grados día superiores a $7,9^{\circ} \mathrm{C}$, cantidad de lluvia y número de días con lluvia acumulados entre julio y setiembre (fechas promedio sin cultivo). A diferencia de lo reportado por Marsella et al (2008), solamente se encontró correlación estadísticamente significativa entre el valor de grados días acumulados (GD) y el número total de trips acumulado en trampas pegajosas en el período estudiado. Para el análisis, los valores de captura fueron transformados a su logaritmo natural y se estimó la siguiente ecuación:

In (número de trips acumulados julio-setiembre) = 0,13+0,01 GD

con un $r^{2}=0,83$ y coeficientes estadísticamente muy significativos. 

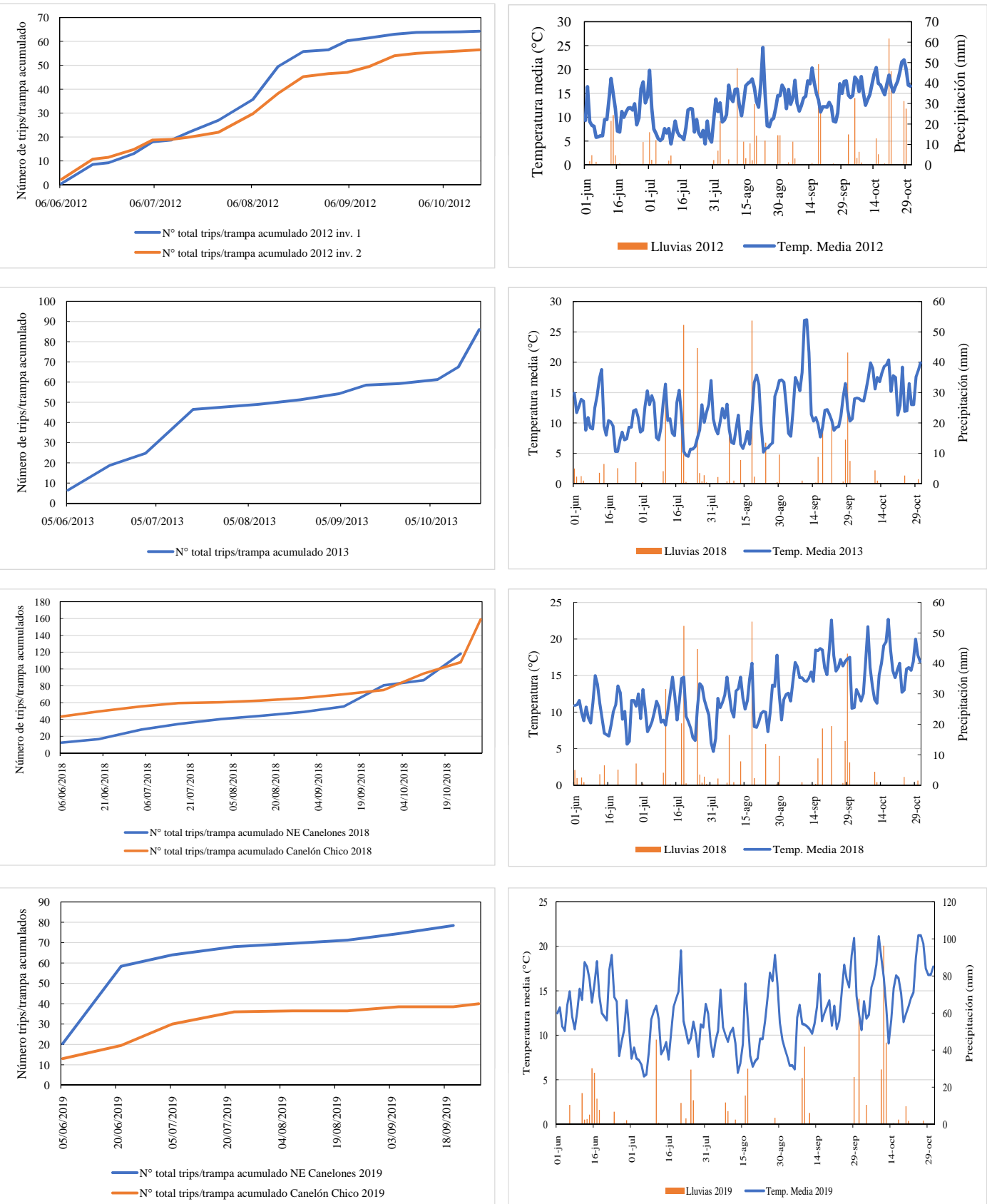

Figura 64. Número acumulado de trips capturados en trampas amarillas pegajosas en el exterior de invernáculos de cultivo de morrón en el período junio-octubre en cuatro temporadas y parámetros climáticos relacionados. 
Respecto al origen de los trips capturados en nuestros seguimientos, en la Figura $65 \mathrm{se}$ presenta la información correspondiente al número de trips colectados en flores de malezas en el exterior de los invernáculos y los individuos capturados en las trampas exteriores en invierno y primavera 2018 y 2019 en las dos zonas estudiadas (Canelón Chico, dos invernáculos y Arenales, cinco invernáculos). Se seleccionaron solamente los valores de colecta en trébol blanco y mostacilla ya que, según lo presentado en el cuadro 8 , serían los que generarían el aporte mayor de adultos en las fechas estudiadas. Como se puede observar, existe una gran coincidencia entre las tendencias de ambos valores por lo que se puede suponer que estas malezas serían las principales fuentes de los vectores que migran desde el exterior durante el período sin cultivo.
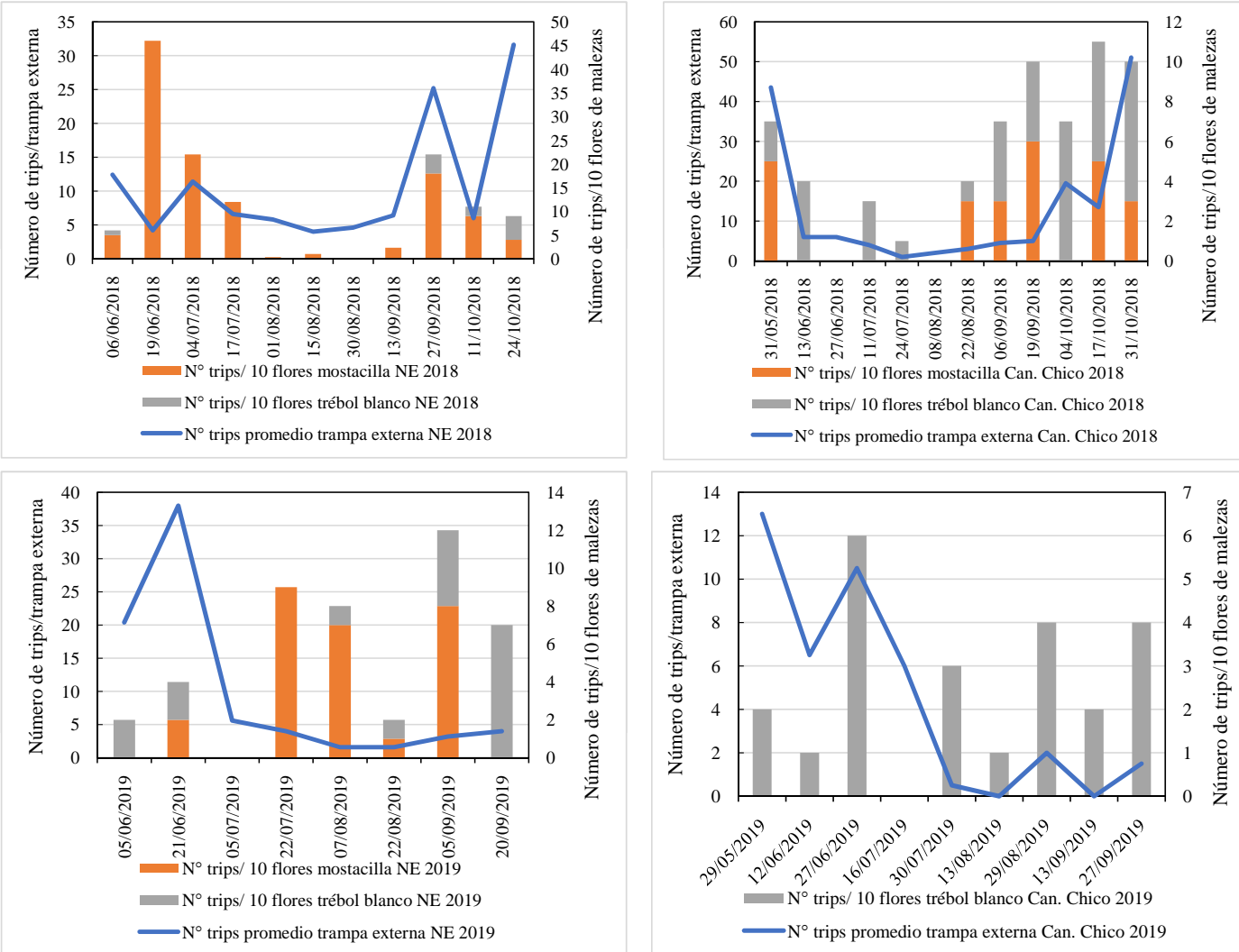

Figura 65. Evolución del número promedio de trips capturados en trampas amarillas pegajosas en el exterior de cinco invernáculos del NE de Canelones (NE) y tres de Canelón Chico (Can. Chico) departamento de Canelones durante junio-setiembre 2018 y 2019 y presencia de trips en flores de algunas malezas.

Otro factor que influye sobre la trasmisión a partir de fuentes de inóculo primarias desde fuera del cultivo es el viento, siendo la incidencia de la enfermedad mayor en los lugares del cultivo que están ubicados a favor de éste (Wilson, 1998; Coutts et al., 2004), principalmente cuando no existe vegetación no huésped o barreras físicas entremedio (Jones 2004, Coutts et al, 2004). Este factor reviste mayor importancia en cultivos a campo que en cultivos realizados en invernadero, dado que el efecto del viento se ve alterado por las corrientes y reparos que se originan en cada establecimiento en particular de acuerdo con la distribución de las estructuras. 
En el seguimiento realizado entre 2011-2014 se colocaron trampas orientadas a los cuatro puntos cardinales y, como se puede ver en la Figura 66, el efecto del viento en las capturas de trips no fue tan marcado y varió entre las temporadas y los dos invernáculos monitoreados. Sí, se encontraron diferencias entre las capturas de las trampas interiores y exteriores y según si el invernáculo poseía mallas anti-insectos perimetrales o no en las temporadas 2012-13 y 2013-14.
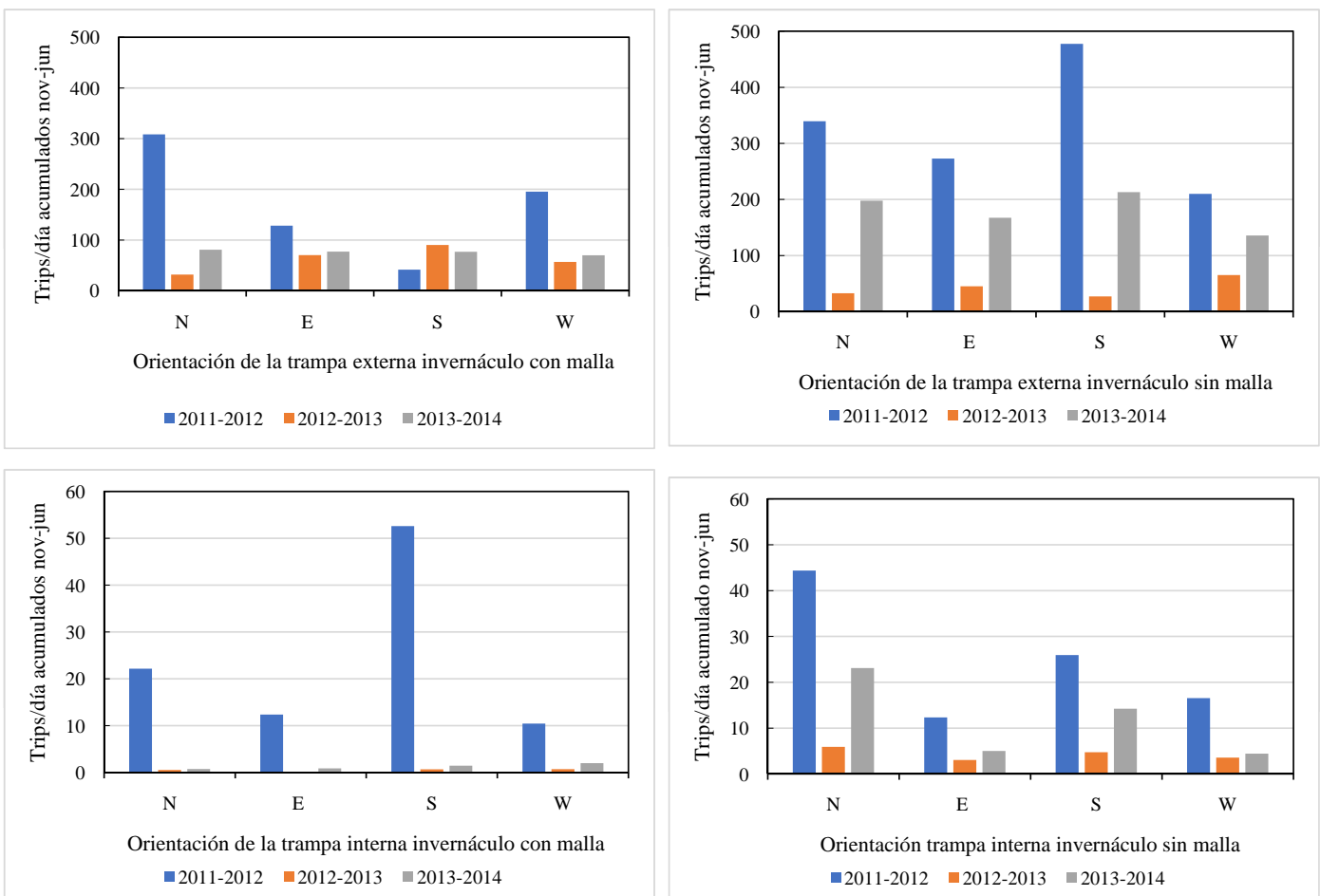

Figura 66. Número de trips/día acumulados entre noviembre y junio en trampas amarillas pegajosas colocadas en el exterior e interior de invernáculos con y sin malla anti-insecto perimetral con cultivos de morrón con diferente orientación.

\section{Permanencia en el interior de los invernáculos.}

Como ya se ha mencionado, la presencia de trips en el interior de los invernáculos entre cultivos puede, entre otros factores, deberse a la emergencia de adultos desde pupas del cultivo anterior y/o de ciclos cumplidos en el interior en huéspedes alternativos o plantas espontáneas del cultivo.

\section{a. Pupas en el inicio de epidemias en nuevos cultivos}

Como se mencionó, los virus causantes de la peste negra en tomate y morrón permanecen dentro del insecto luego de la muda por lo que las pupas que se mantienen quiescentes en las primeras capas del suelo y restos de cultivos también constituyen una importante fuente de adultos infectivos para los nuevos cultivos. Se ha estimado que esa permanencia puede prolongarse hasta 2-3 semanas (Cho et al., 1989) luego de levantado un cultivo, aunque existen referencias de quiescencia en suelo durante el invierno mucho más prolongadas (Roselló et al., 1996). 
En algunos estudios que hemos realizado colocando trampas pegajosas en diferentes puntos y alturas en un invernadero, luego de finalizado un cultivo de morrón nos han brindado datos que ponen en evidencia la emergencia de adultos a partir de pupas localizadas en suelo. En un invernáculo de la zona de Canelón Chico con antecedentes de la enfermedad se colocaron diez trampas diseñadas para que solo capturaran adultos que emergieran del hueco donde estuvieron las plantas, diez para que capturan los adultos emergentes del suelo entre filas, y dos trampas verticales a 0,2 $\mathrm{m}$ de altura y dos a 1,5 m (Figura 67). El cultivo de pimiento fue retirado a mediados de agosto 2018 y el cultivo posterior de tomate trasplantado a comienzos de octubre 2018. Como se observa en la Figura 68, se capturaron adultos en todas las trampas luego del retiro del cultivo. Es de destacar la captura de adultos en las trampas colocadas a nivel del suelo en la fila y en la entre fila, a pesar de lo reducido de su alcance (dos ventanas de $10 \times 10 \mathrm{~cm}$ ) lo cual coincide con lo observado por Groves et al. (2003) con F. fusca. Los valores más altos de las capturas en las trampas bajas frente a las altas también apuntan al origen de los insectos, que, suponemos que no permanecieron en el invernadero debido a la ausencia de cultivo y de huéspedes alternativos.

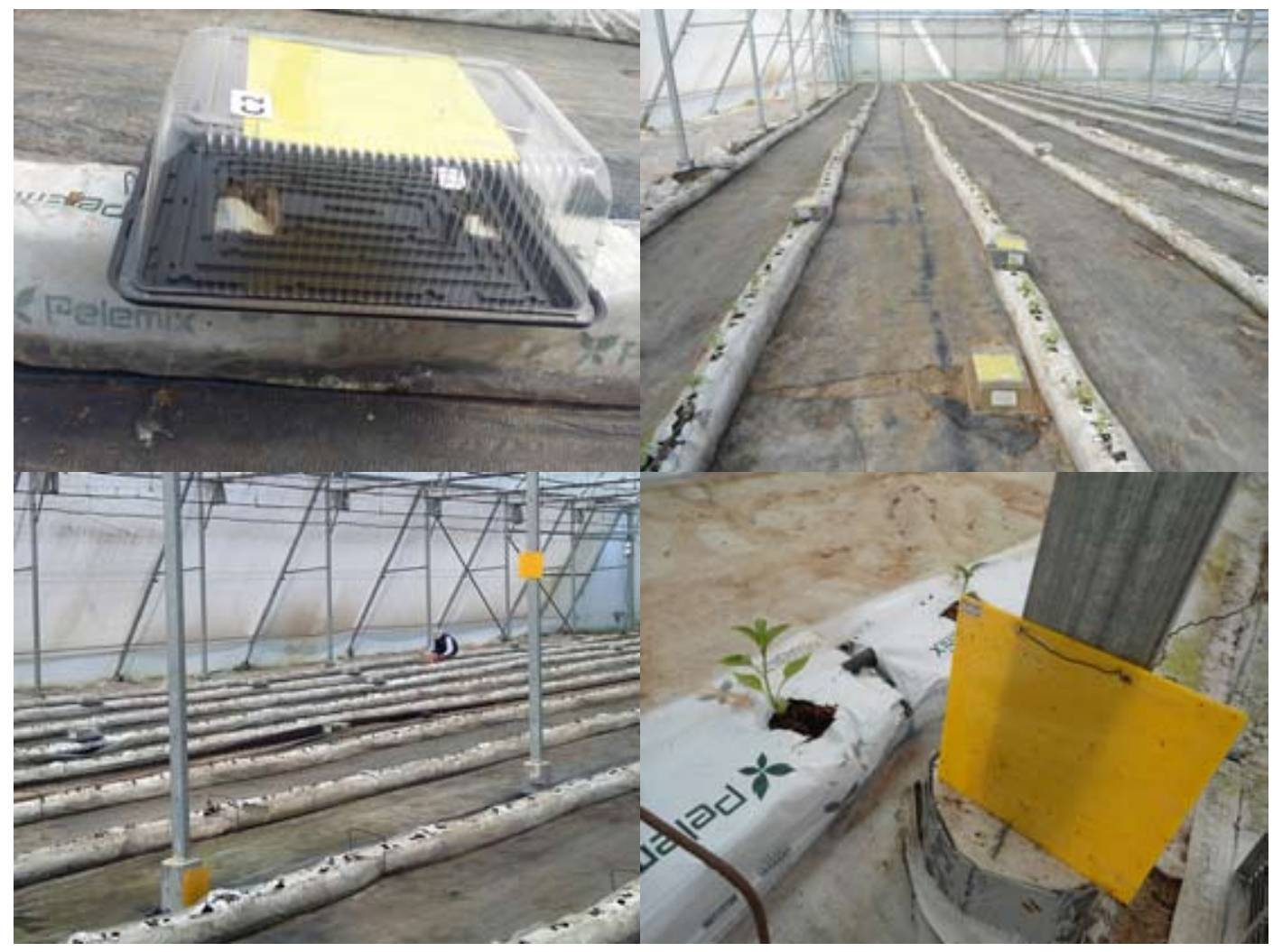

Figura 67. Disposición de trampas amarillas pegajosas utilizadas para estudiar evolución de capturas de trips en el periodo entre cultivos (agosto-noviembre 2018). Arriba trampas colocadas para capturar adultos emergentes de pupas en suelo. Abajo disposición de trampas a $20 \mathrm{~cm}$ y a $150 \mathrm{~cm}$ del piso. Fotos D. Maeso. 


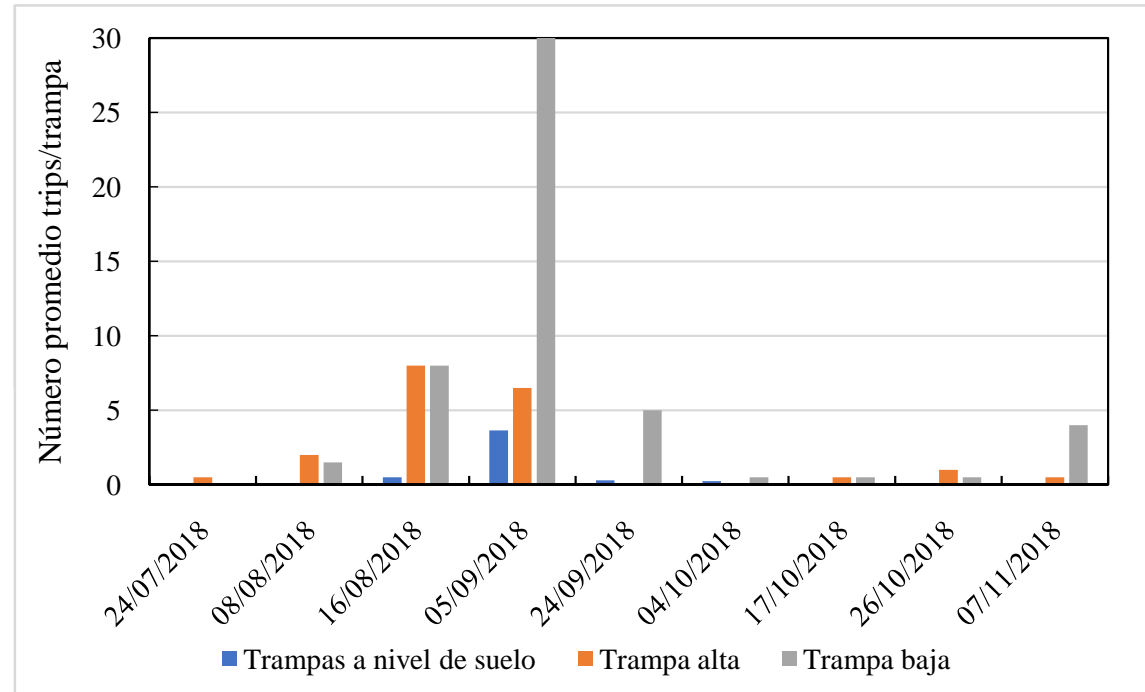

Figura 68. Captura promedio de trips (F. occidentalis) en trampas amarillas pegajosas colocadas en diferentes posiciones en un invernáculo entre cultivos de morrón: a nivel de suelo (10 en el hueco de las plantas y 10 en las entre filas), dos a $20 \mathrm{~cm}$ y dos a $150 \mathrm{~cm}$ de altura.

En la figura 69 se muestran los valores promedio totales de captura durante todo el período de estudio de las dos trampas localizadas a 0,20 m del piso y de las dos a 1,5 m. Como se puede apreciar, el proceso se repite durante el período analizado, cuando existe cultivo las capturas en trampas bajas son menores que las registradas en trampas altas, pero, cuando el invernáculo se encuentra vacío (agosto-setiembre en ambos años) predominan las capturas en trampas bajas, presumiblemente de adultos que emergen de pupas remanentes del cultivo previo. Luego, podemos suponer que el proceso prosigue, pero el número de capturas se ve incrementado por la abundancia de vegetación dentro del invernáculo y la migración desde el exterior en temporada de cultivo.

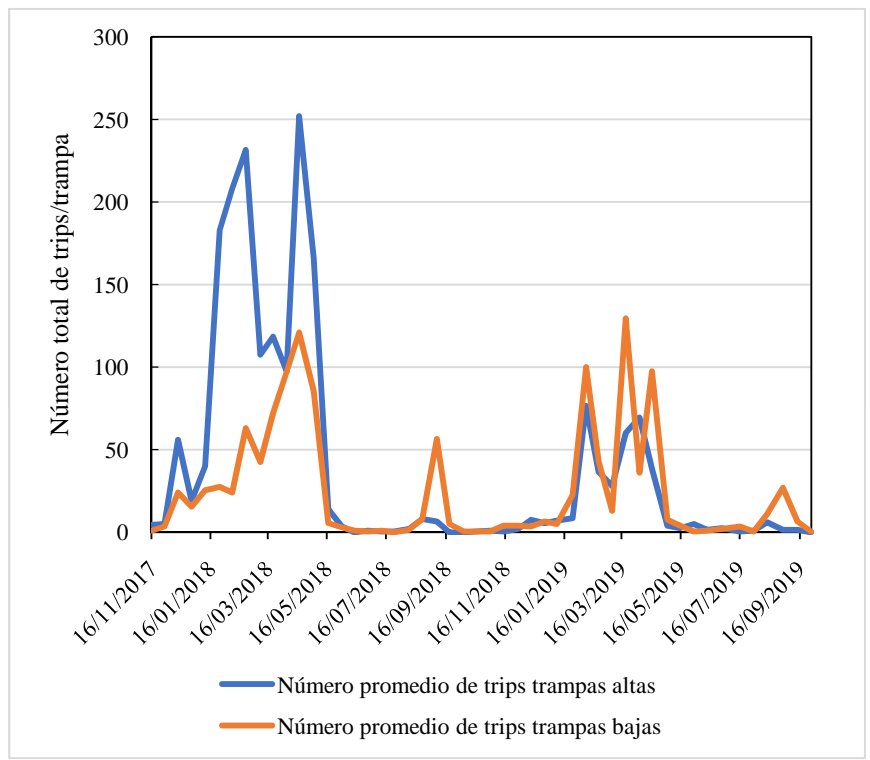

Figura 69. Evolución del número de trips capturados en trampas amarillas pegajosas en el interior de un invernáculo en Canelón Chico en dos posiciones (0,2 y 1,5 m, promedio de dos trampas por posición). 


\section{b. Huéspedes alternativos en el interior de los invernáculos.}

En la figura 70 se presenta la evolución de las capturas en trampas pegajosas amarillas ubicadas en el interior de invernáculos durante el periodo sin cultivo en un trabajo, ya descrito, que fue realizado en establecimientos de dos zonas del departamento de Canelones durante 2017-2019. Los valores son el promedio de las capturas para cada fecha y se asocian con el número de trips, también promedio, encontrado en diez flores de cada una de las malezas más frecuentes en el período, y que aportaban los mayores valores del vector. Como se puede observar, la captura de trips en trampas en el interior de los invernáculos sigue la misma tendencia que la cantidad de individuos presentes en las flores de las malezas más relevantes, lo cual, como dijimos en párrafos anteriores, sumado a los adultos emergentes de pupas explicarían la presencia de trips en el interior de los invernáculos, los cuales, en caso de ser infectivos, se encargarán de cerrar el ciclo de la enfermedad infectando al nuevo cultivo.
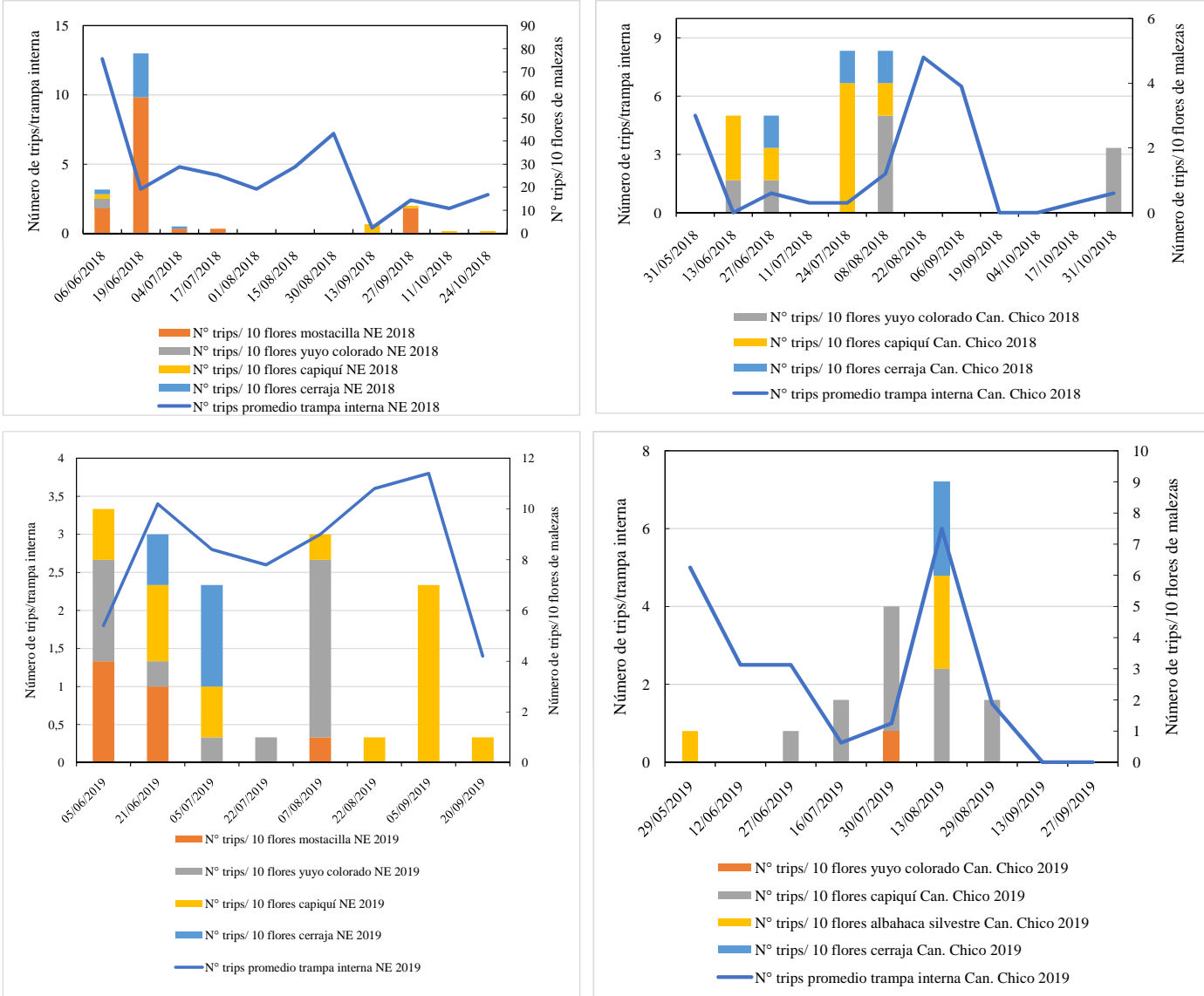

Figura 70. Evolución del número promedio de trips capturados en trampas amarillas pegajosas en el interior de cinco invernáculos del NE de Canelones (NE) y tres de Canelón Chico (Can. Chico) departamento de Canelones durante junio-setiembre 2018 y 2019 y presencia de trips en flores de algunas malezas dentro de los invernáculos. 


\section{c. Transmisión desde frutos}

Si bien la transmisión a partir de frutos dejados en el cultivo no es mencionada como uno de los principales componentes del ciclo de la enfermedad, Okazaki et al., 2007, reportan que en ciertas regiones de Japón los frutos verdes de morrón descartados son una fuente de inóculo primario muy importante para la infección de huéspedes alternativos que cierran el ciclo. Por su parte Szostek et al. 2017 confirmaron la adquisición de virus desde frutos de tomate con síntomas leves. Aramburu et al. (2000) pusieron de manifiesto la alimentación y trasmisión de TSWV de trips en frutos de tomate, aún en variedades resistentes que únicamente muestran síntomas en frutos lo cual, además puede ser un factor para promover el desarrollo y diseminación de cepas resistentes.

\section{Evolución de la población del vector y la enfermedad en la estación de cultivo.}

Como ya se discutió, la presencia de trips en el interior de los invernáculos en períodos sin cultivo depende de la migración desde el exterior y de la permanencia en el interior, ya sea desde pupas remanentes del cultivo anterior o desde las malezas y plantas espontáneas presentes.

Una vez comenzada la estación de cultivo, la migración desde el exterior continúa y, como se presentó en las figuras 62 y 63, el número de trips capturados en el interior de los invernáculos está altamente correlacionado con las capturas en las trampas externas. El nivel de establecimiento y reproducción del vector dependerá de las condiciones ambientales, fundamentalmente temperatura y con la cantidad y tipo de vegetación existente.

\section{a. Efecto de la temperatura sobre la población de trips en el interior de los invernáculos.}

Durante el estudio en morrón de 2018-2019, ya mencionado, se registró la temperatura en el interior de los invernáculos y se analizó su influencia sobre la cantidad de trips capturados. En la figura 71 se pueden ver algunos ejemplos de los registros de la temperatura media interior (valor promedio en los períodos de trampeo) y de la cantidad de trips capturados en promedio en los invernáculos de cada zona. La temperatura media interna nunca fue inferior a $10^{\circ} \mathrm{C}$, por lo cual, en teoría, según ya se mencionó en el texto, permitiría la existencia del vector durante todo el período.

Se observa un incremento marcado de la captura en el interior asociado con el aumento de la temperatura coincidiendo con el periodo con cultivo. Esto, como ya vimos, reduce la duración del ciclo del vector y causa otros efectos positivos en su ciclo de vida. Al realizar un análisis de correlación y regresión con esos valores se encontró que las capturas de trips en el interior de los invernáculos estudiados estuvo significativamente correlacionada con la temperatura media del período de trampeo en el interior de los invernáculos (Figura 72). 

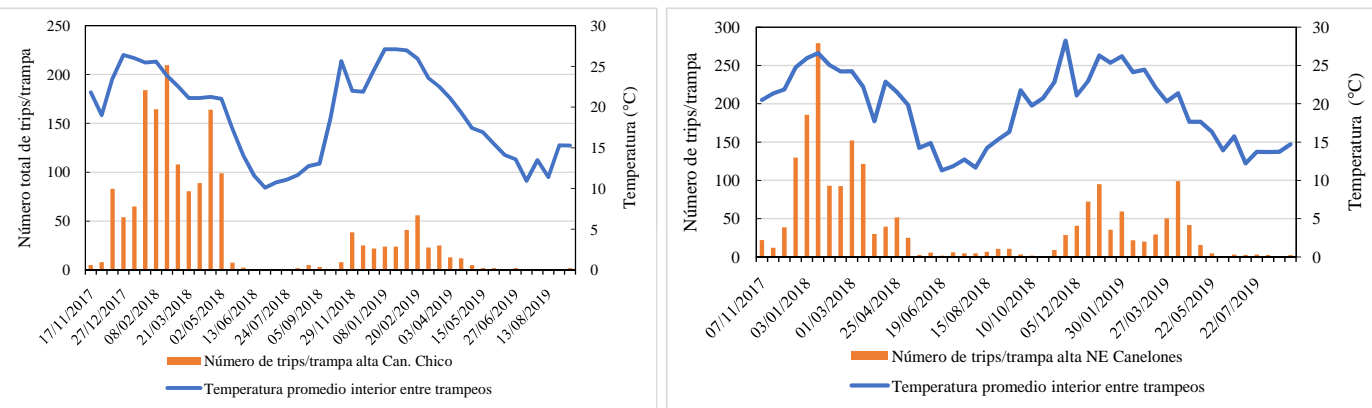

Figura 71. Relación entre temperatura y el número de trips capturados en trampas amarillas pegajosas ubicadas en el interior de tres invernáculos en Canelón Chico (izquierda) y cinco en el Noreste de Canelones (derecha).
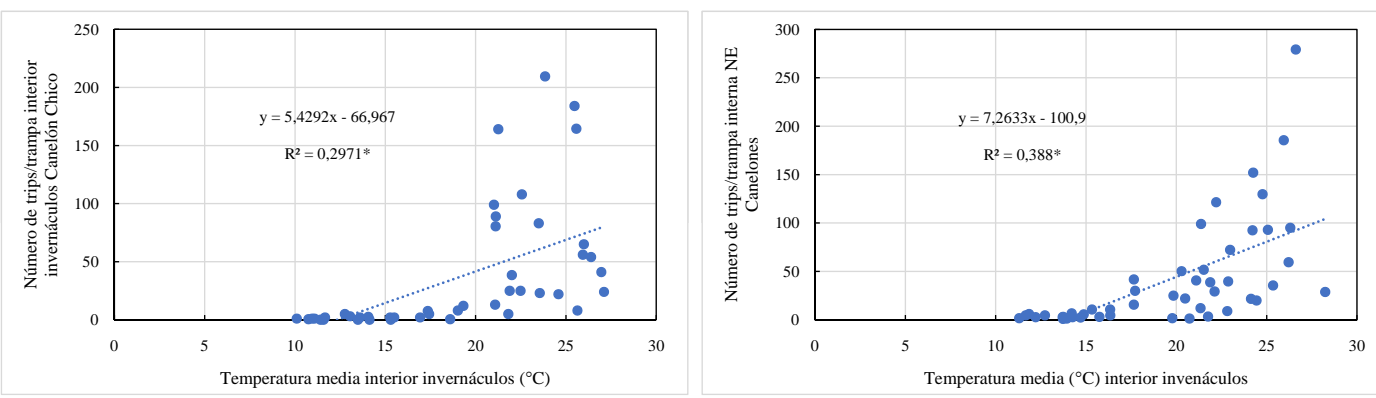

Figura 72. Relación entre la temperatura interior registrada y la captura de trips en trampas pegajosas amarillas en invernáculos del NE de Canelones y Canelón chico.

\section{b. Probables fuentes internas de los vectores.}

Haciendo un análisis similar al efectuado para la etapa sin cultivo de morrón, podemos realizar algunos supuestos acerca de las principales fuentes de trips en la estación de cultivo. En la Figura 73 se grafican los valores promedios de las capturas en trampas internas y la cantidad de trips en flores de morrón y de algunas de las principales malezas (promedio de diez flores/fechal en las dos temporadas en los invernáculos del noreste de Canelones, y en la Figura 74 en los invernáculos de Canelón Chico (promedios de los valores de los invernáculos estudiados) en la época de cultivo. El número de trips capturados en el interior de los invernáculos en ambas zonas sigue la misma tendencia que el número de individuos presentes en las flores del cultivo y de las principales malezas, lo cual indicaría la reproducción y circulación interna de individuos entre plantas del cultivo y de malezas, y por lo tanto posibilitando, en caso de existir plantas enfermas, la ocurrencia de ciclos sucesivos de la enfermedad durante la estación. 

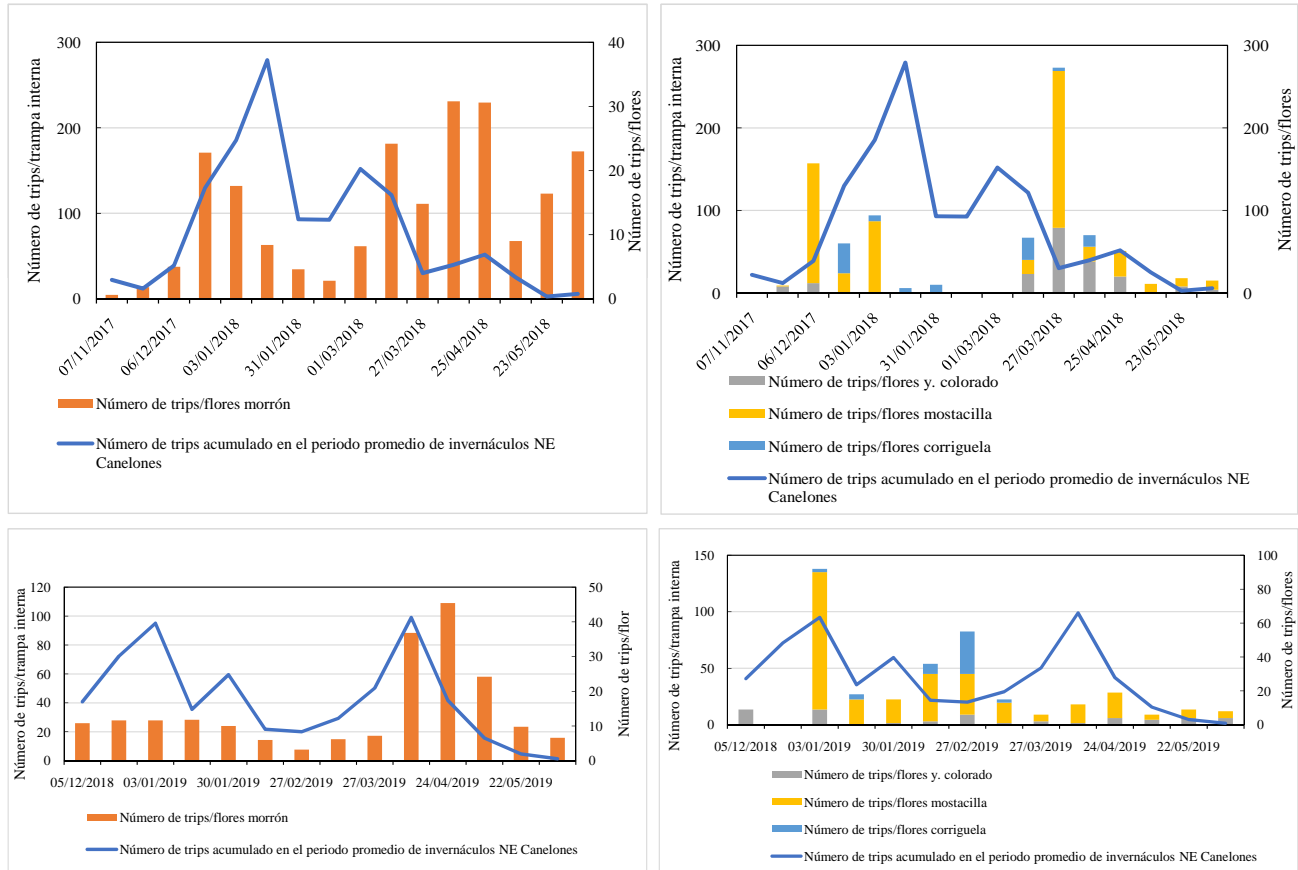

Figura 73. Evolución del número de trips capturados en trampas pegajosas amarillas en el interior de invernáculos del noreste de Canelones comparado con el número de individuos en flores de morrón y las malezas predominantes (promedio de diez flores por especie).
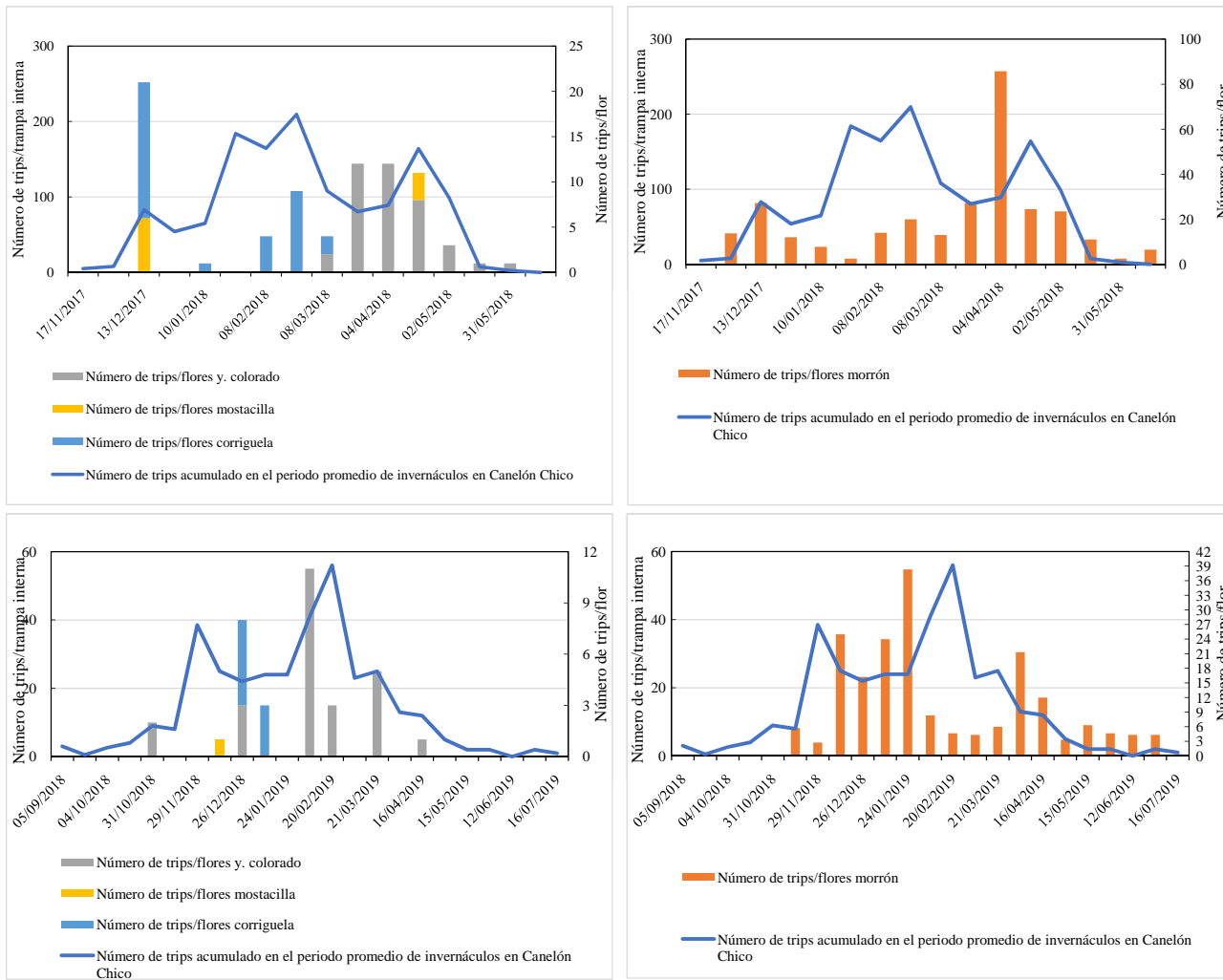

Figura 74. Evolución del número de trips capturados en trampas pegajosas amarillas en el interior de invernáculos de Canelón Chico comparado con el número de individuos en flores de morrón y las malezas predominantes (promedio de diez flores por especie).

103 
Simplemente como comparación en la Figura 75 se muestran algunos de los registros de seguimientos realizados a cultivos de tomate. En primer lugar, se puede observar que solo en pocas oportunidades se colectaron trips en flores de tomate, y, al igual que en morrón, sí en flores de malezas. Si bien no se cuentan con valores de capturas en trampas para toda la estación, no existe una relación tan marcada con la presencia en flores en el interior del invernáculo, por lo que se puede suponer que en el cultivo de tomate la fuente externa de trips también estaría involucrada, lo cual explicaría la ocurrencia de epidemias monocíclicas en este cultivo (cuadro 13).

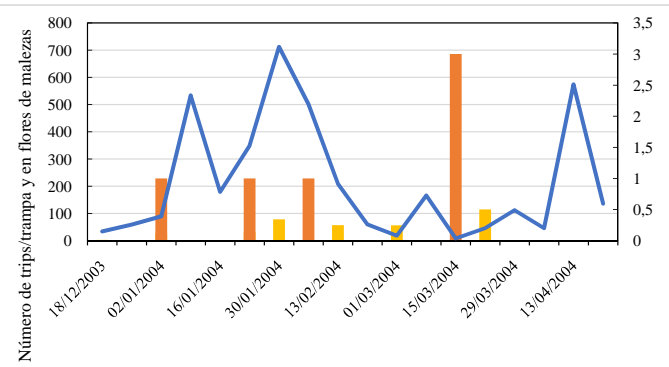

Número de trips/flor malezas $=$ Número de trips/flor tomate Número de trips/trampa

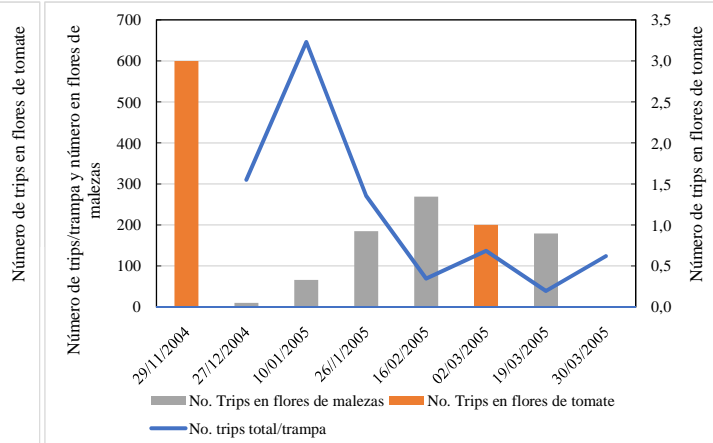

No. trips total/trampa

Figura 75. Captura de trips en trampas amarillas y colecta en flores de tomate y malezas durante cultivos en invernáculo en las temporadas 2003-2004 y 2004-2005 en INIA Las Brujas.

\section{c. Proporción de vectores infectivos frente al número total de individuos presentes en cultivo.}

Como se describió en el apartado anterior, en los cultivos de morrón estudiados estarían dadas las condiciones para la reproducción y migración interna de trips entre plantas. Las condiciones ambientales en el interior del invernáculo favorecen la abundancia de individuos adultos, pero, en lo que respecta a la ocurrencia de la enfermedad, todo dependerá de si estos son portadores de virus, lo cual estará muy vinculado a la existencia de plantas enfermas. Existen numerosos trabajos que han estudiado la variación de los niveles poblacionales de trips a través de captura en trampas pegajosas y los vincularon con posteriores ataques de peste negra (Cho et al. 1995; Westmore et al., 2019). Si bien las epifitias de peste negra están relacionadas con el nivel poblacional de trips (Cho et al 1987, Puche et al 1995), la magnitud de los ataques no siempre puede ser explicada por el número de individuos presentes en el cultivo (Yudin et al., 1990). Esto se debe a que, para el desarrollo de la enfermedad importa más la proporción de vectores virulíferos que el número total de individuos presentes (Bandla et al., 1994; Aramburu et al., 1997), lo cual es algo a tener muy presente en el manejo de esta enfermedad. Lo anterior explicaría, según Aramburu et al. (1997), por qué si bien en las fechas tardías de plantación de tomates en Cataluña se registran menores poblaciones de vectores que en las tempranas, siempre se registran grandes ataques de peste negra. Información similar fue encontrada en Mendoza, Argentina (De Borbón com. pers.). Por lo tanto, a pesar de que los trips pueden provocar daños directos como plaga cuando están en gran número, para prevenir los ataques de peste negra se debe disminuir el número de trips infectivos, y no necesariamente eliminar totalmente al insecto. 
Lo inverso ha sido reportado con $F$. fusca, en fechas tempranas, en las cuales poblaciones bajas al comienzo de primavera, son responsables de grandes tasas de trasmisión de peste negra a cultivos de tomate (Nault et al., 2003; Groves et al., 2003), lo cual es explicado por la alta proporción de adultos infectivos que llegan desde huéspedes alternativos en esa fecha.

Lo anterior sumado a que las plantas infectadas pueden permanecer sin síntomas por un período prolongado (15-25 días pos-inoculación), introduce dificultades en el manejo de la enfermedad, al no poder detectar a tiempo la transmisión "silenciosa" ocasionada por un número reducido de vectores sin presencia rápida de plantas con síntomas conspicuos.

La cantidad de vectores acumulada capturados en un cultivo aumenta durante la temporada, principalmente con el aumento de la temperatura, hasta llegar a otoño en que se estaciona y las capturas son mínimas. Si bien en este momento existe trasmisión, el impacto es menor y su significado epidemiológico radica en la infección de los huéspedes alternativos para cerrar el ciclo (Groves et al., 2003).

A modo de ejemplo para ilustrar este tema con información local, presentaremos los resultados de algunos de los trabajos de seguimiento de la evolución de la enfermedad y de la población del vector en trampas y en flores del cultivo y malezas en tomate, en los que, en algunos casos, se realizó el análisis de los vectores colectados. Durante las temporadas 1997-1998 y 1999-2000, se expusieron semanalmente en un cultivo de tomate en un invernadero de Rincón del Colorado (departamento de Canelones) grupos de plantas de petunia, las que, una vez terminado su período de exposición, se mantuvieron en un invernáculo a prueba de insectos por una semana a la espera del desarrollo de las lesiones locales típicas de TSWV (Figura 76). 


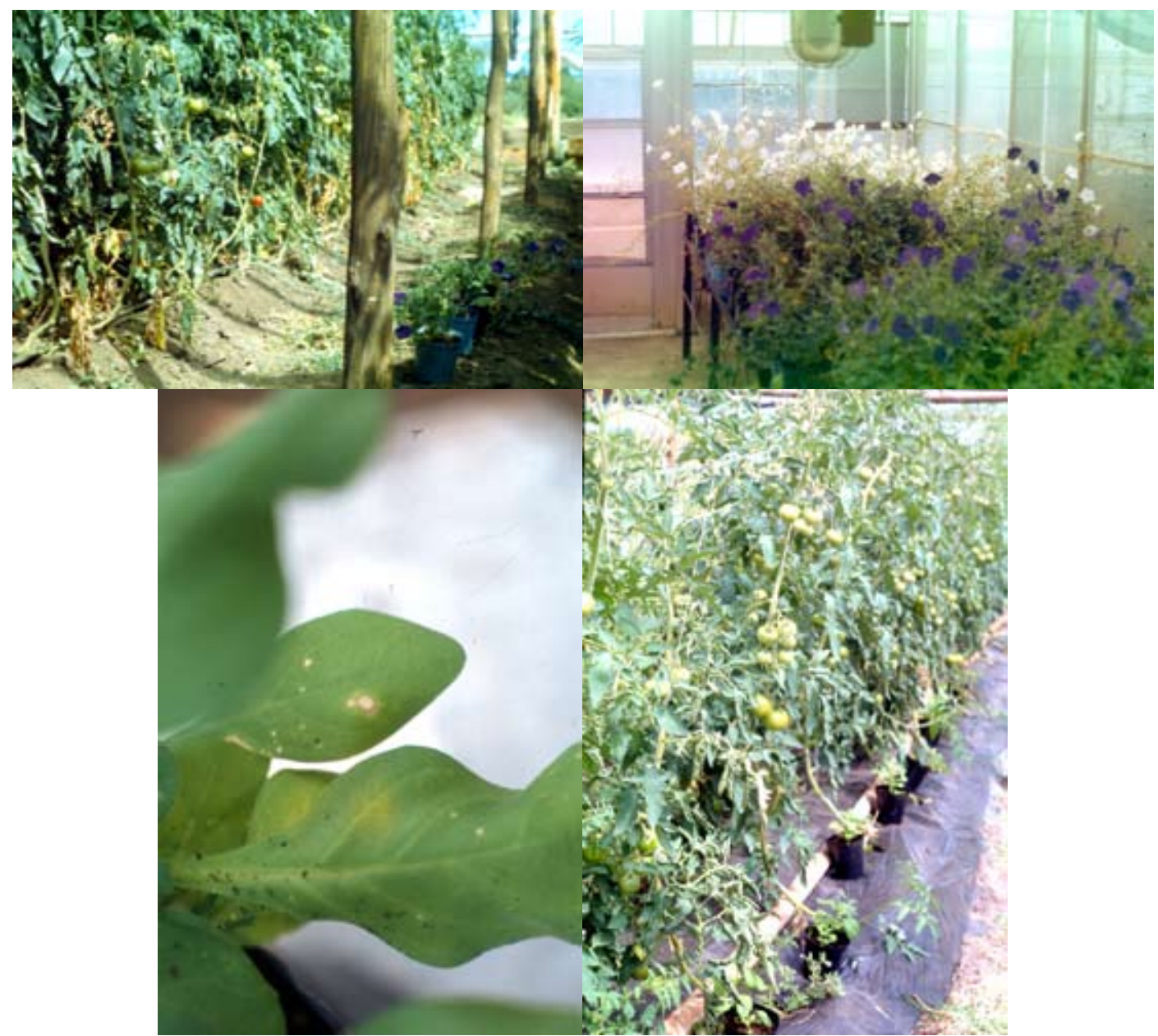

Figura 76. Experimento de seguimiento de un ataque de peste negra en tomate en un invernadero de Rincón del Colorado lCanelones) durante 1997-1998 y 1999-2000. Arriba izquierda: Vista general del experimento, derecha: plantas expuestas en evaluación; abajo izquierda: lesiones desarrolladas en plantas expuestas y abajo derecha: plantas expuestas en proximidad de plantas con síntomas.

En 1997-1998 el cultivar de tomate era Superman (resistente a peste negra), mientras que en 1999-2000, fue Dominique (susceptible). En el experimento 1997-1998, como se trató de un cultivar resistente, el cultivo no presentó síntomas, sin embargo, se capturaron trips y de acuerdo con los síntomas desarrollados en las plantas de petunia, parte de ellos serían infectivos. Como se aprecia en la figura 77 y el cuadro 14, existieron periodos en que el porcentaje de petunias con lesiones fue alto, a pesar de que la cantidad del vector no lo era. Esta planta ha sido recomendada como un indicador biológico eficiente en determinar la presencia de trips capaces de trasmitir peste negra (Allen y Matteoni, 1991), pero, de acuerdo con nuestra experiencia se debe tener cuidado porque algunas lesiones provocadas por insectos pueden llevar a confusión. Las trampas pegajosas estimarían la población total de individuos adultos dentro del cultivo, las lesiones en las plantas de petunia si hubo trasmisión y, el análisis mediante NC-ELISA de los insectos colectados de flores de tomate si éstos portaban virus (Figura 36). Como se puede observar en el cuadro 14, el 25/1 a pesar de haberse capturado un número importante de individuos (868) en las trampas pegajosas, 
solo en el $2,5 \%$ de los colectados de las flores del cultivo se pudo detectar TSWV. Si bien no se realizaron análisis en fechas anteriores, los resultados en petunia y los síntomas en tomate muestran que durante noviembre con número bajo de captura en trampa hubo trasmisión.

Algo similar ocurrió en los seguimientos realizados durante 2003-2004 de dos cultivos en INIA Las Brujas en los que la mayor detección de TSWV en trips colectados de flores de malezas o tomate no siempre se registró cuando la captura de trips en trampas era la más elevada (Maeso et al., 2005), (Figura 78).

En todos los casos estudiados, el número de trips colectados en flores de tomate y la detección de TSWV en ellos fueron muy bajos, frente al encontrado en flores de malezas, lo cual concuerda con que la planta de tomate no es un huésped preferido para la colonización por este insecto.

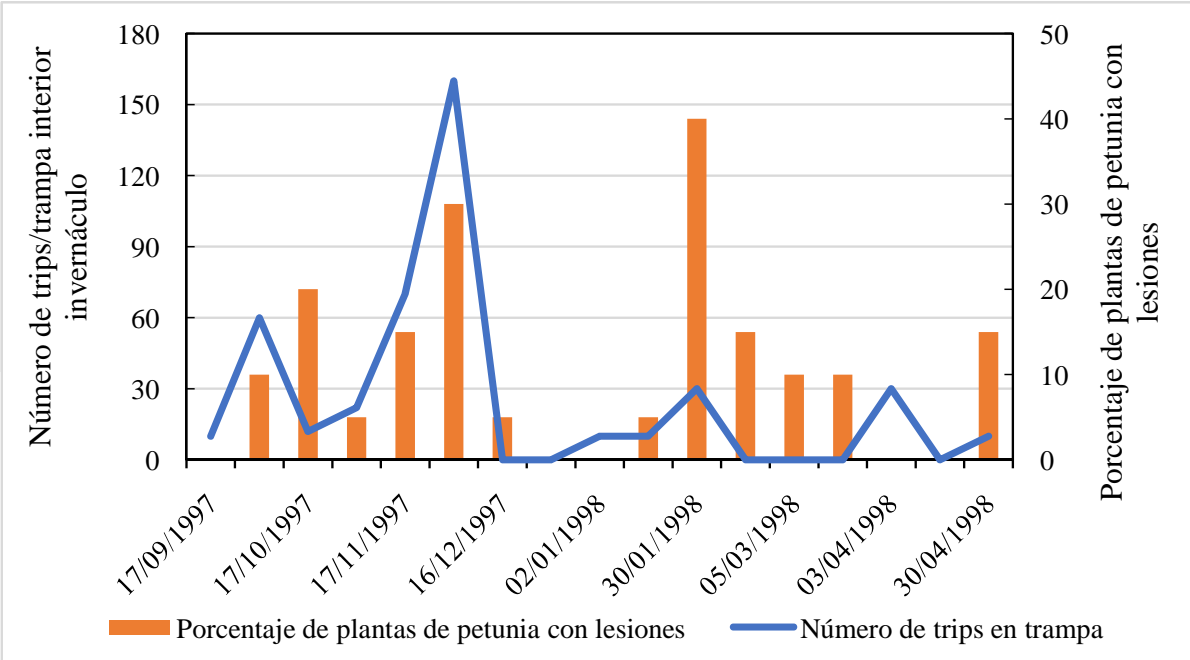

Figura 77. Relación entre el número de trips colectados en trampas amarillas pegajosas en el interior de un invernáculo con el porcentaje de plantas de petunia expuestas que desarrollaron lesiones en un cultivo comercial de tomate variedad Superman durante 1997-98 en Rincón del Colorado (Departamento de Canelones).

Cuadro 14. Determinación de la capacidad de trasmisión de peste negra y su relación con la presencia de trips.

\begin{tabular}{|c|c|c|c|c|c|}
\hline Fecha & $\begin{array}{c}\text { Número } \\
\text { de trips/ } \\
\text { trampa } \\
\text { pegajosa }\end{array}$ & $\begin{array}{c}\text { Porcentaje } \\
\text { de trips } \\
\text { TSWV }+ \\
\text { (NC-ELISA) }\end{array}$ & $\begin{array}{c}\text { Porcentaje } \\
\text { de petunias } \\
\text { con lesiones } \\
\text { locales/fecha }\end{array}$ & $\begin{array}{c}\text { Porcentaje } \\
\text { acumulado } \\
\text { de plantas } \\
\text { de tomate } \\
\text { con síntomas }\end{array}$ & $\begin{array}{c}\text { Porcentaje } \\
\text { acumulado de } \\
\text { plantas con } \\
\text { detección TSWV } \\
\text { (DAS-ELISA) }\end{array}$ \\
\hline $10 / 11 / 1999$ & 28 & --- & 47 & 7 & 0 \\
\hline $24 / 11 / 1999$ & 203 & --- & 40 & 14 & 0 \\
\hline $15 / 12 / 1999$ & 1477 & $16,7(1 / 6)$ & 53 & 24 & 24 \\
\hline $03 / 01 / 2000$ & --- & $12,5(1 / 8)$ & 0 & 41 & 24 \\
\hline $25 / 01 / 2000$ & 868 & $2,5(2 / 80)$ & 0 & 69 & 72 \\
\hline
\end{tabular}



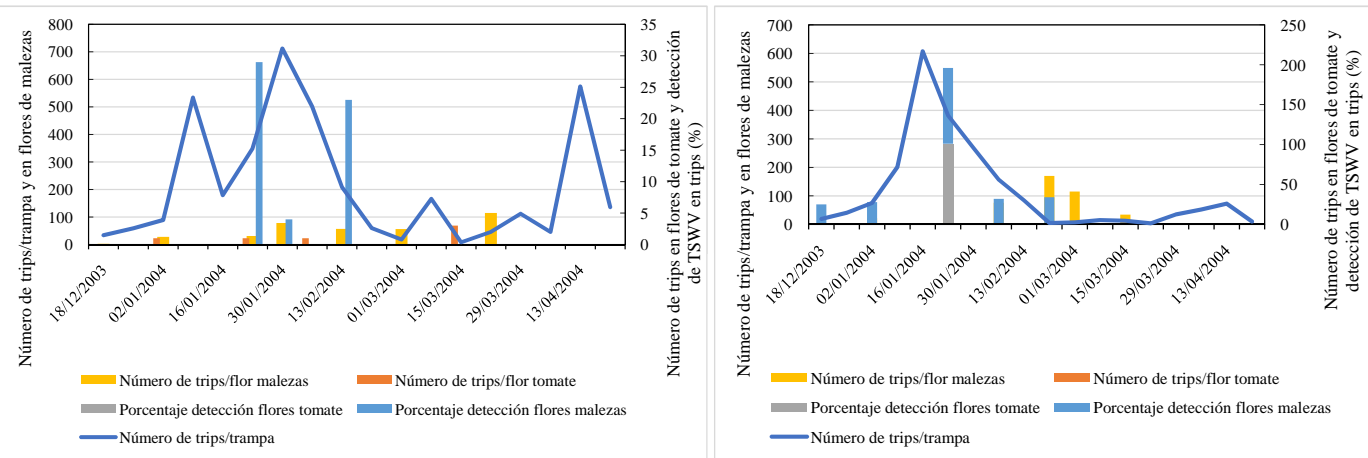

Figura 78. Detección de TSWV en trips en relación con la captura en trampa pegajosa. Izquierda cultivo a campo, derecha cultivo en macrotúneles.

\section{d. Secuencia de eventos en el desarrollo de un ataque de peste negra.}

De acuerdo con la información colectada durante los seguimientos realizados tanto en tomate como en morrón durante varios años, y que en parte se ha presentado en los numerales anteriores, podemos inferir que la secuencia de eventos en el desarrollo de la enfermedad es la siguiente:

1) Al final de los cultivos, si estos han presentado la enfermedad, quedan en los invernáculos pupas que darán lugar a adultos infectivos los cuales, dependiendo de la duración de ese estadio, pueden infectar malezas en el interior del invernáculo o directamente al nuevo cultivo trasplantado.

2) En paralelo, los adultos infectivos, provenientes de las pupas mencionadas y/o del cultivo o malezas de estación, infectan y establecen colonias en flores de malezas tanto en el interior como en el exterior de los invernáculos, generando un "puente verde" que mantiene al vector y al virus en una secuencia durante otoño-invierno hasta la próxima temporada de cultivo.

3) Una vez trasplantado, el cultivo recibe la migración de vectores infectivos desde el exterior o del interior del invernáculo generando el comienzo de la enfermedad. Dependiendo de la duración del ciclo, la cantidad de vector existente, la preferencia de este por el cultivo, la cantidad de plantas infectadas tanto del cultivo como de malezas el ataque quedará en un ciclo único de infección o dará lugar a múltiples eventos.

En la Figura 79 se representa lo anterior a modo de diagrama. En las Figuras 80 y 81 se muestra el proceso tal como fue registrado experimentalmente durante algunos de nuestros trabajos de seguimiento en tomate y morrón en la zona sur. Específicamente se muestra la evolución de eventos en dos cultivos de tomate variedad Coloso en invernáculo en INIA Las Brujas durante 2003-2004. En el cultivo de ciclo noviembre-febrero, se registraron en un primer momento trips en flores de malezas, en los cuales de detectó TSWV conjuntamente con la aparición de síntomas, lo cual fue seguido en fechas posteriores por la captura de altos número de vectores en trampa pegajosa. Hacia fin del período analizado, la incidencia de la enfermedad aumenta abarcando casi la totalidad de las plantas, lo cual coincide con 
el alto número de vectores tanto en trampa como en flores y el alto porcentaje en los que se detecta TSWV. La presencia de trips en flores se encontró fundamentalmente en malezas ya que, como se mencionó, las prefieren a las flores del tomate. El cultivo que se trasplantó a continuación, a partir de febrero, si bien continuó el proceso anterior, el número de trips total disponible tanto en flores como en trampa fue menor y, fundamentalmente también fue menor el porcentaje de estos en los que se detectó el virus lo cual suponemos que influyó en la menor incidencia de la enfermedad.

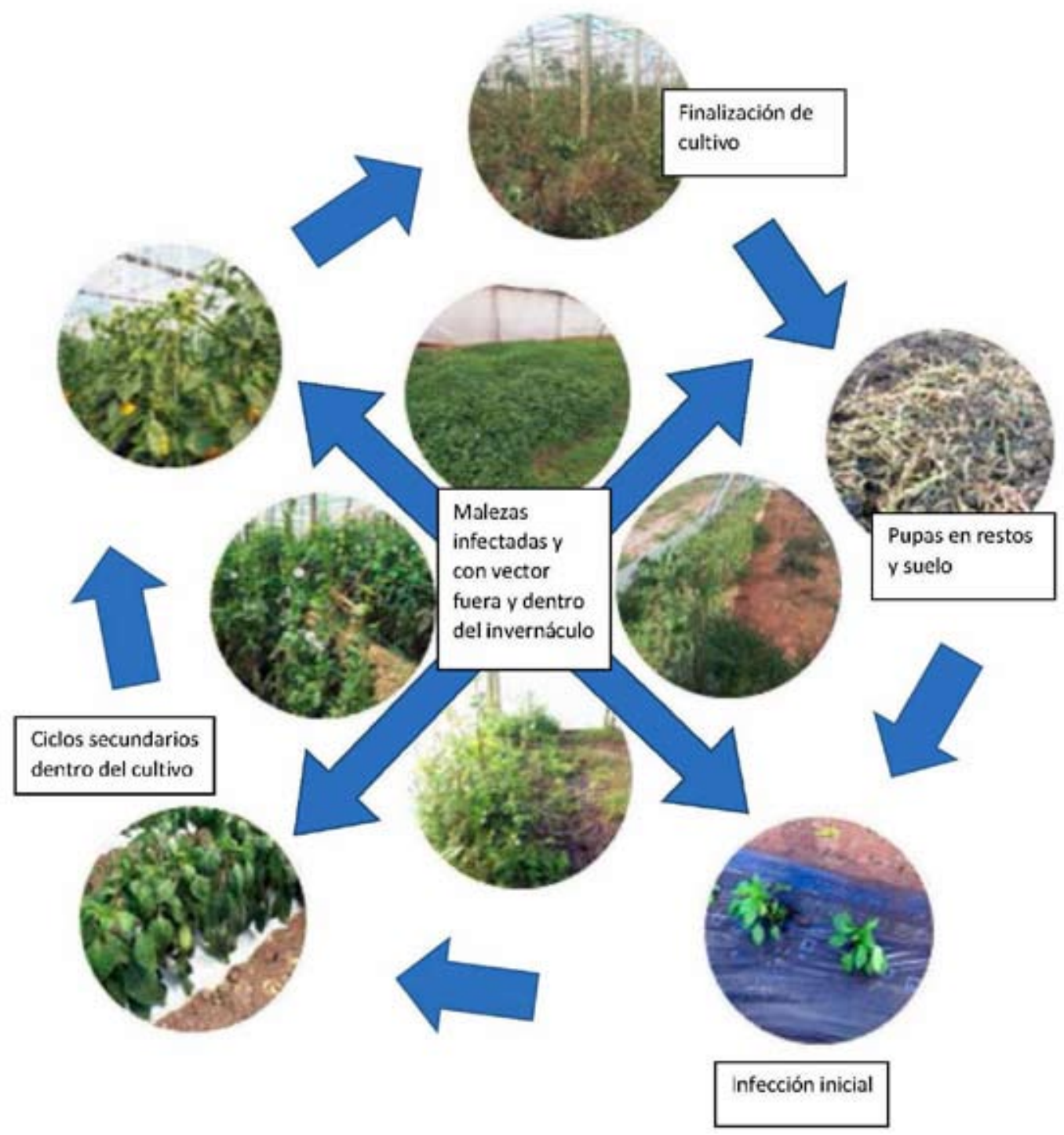

Figura 79. Esquema de eventos en el desarrollo de un ataque de peste negra en cultivos bajo invernáculo en la zona sur de Uruguay. 

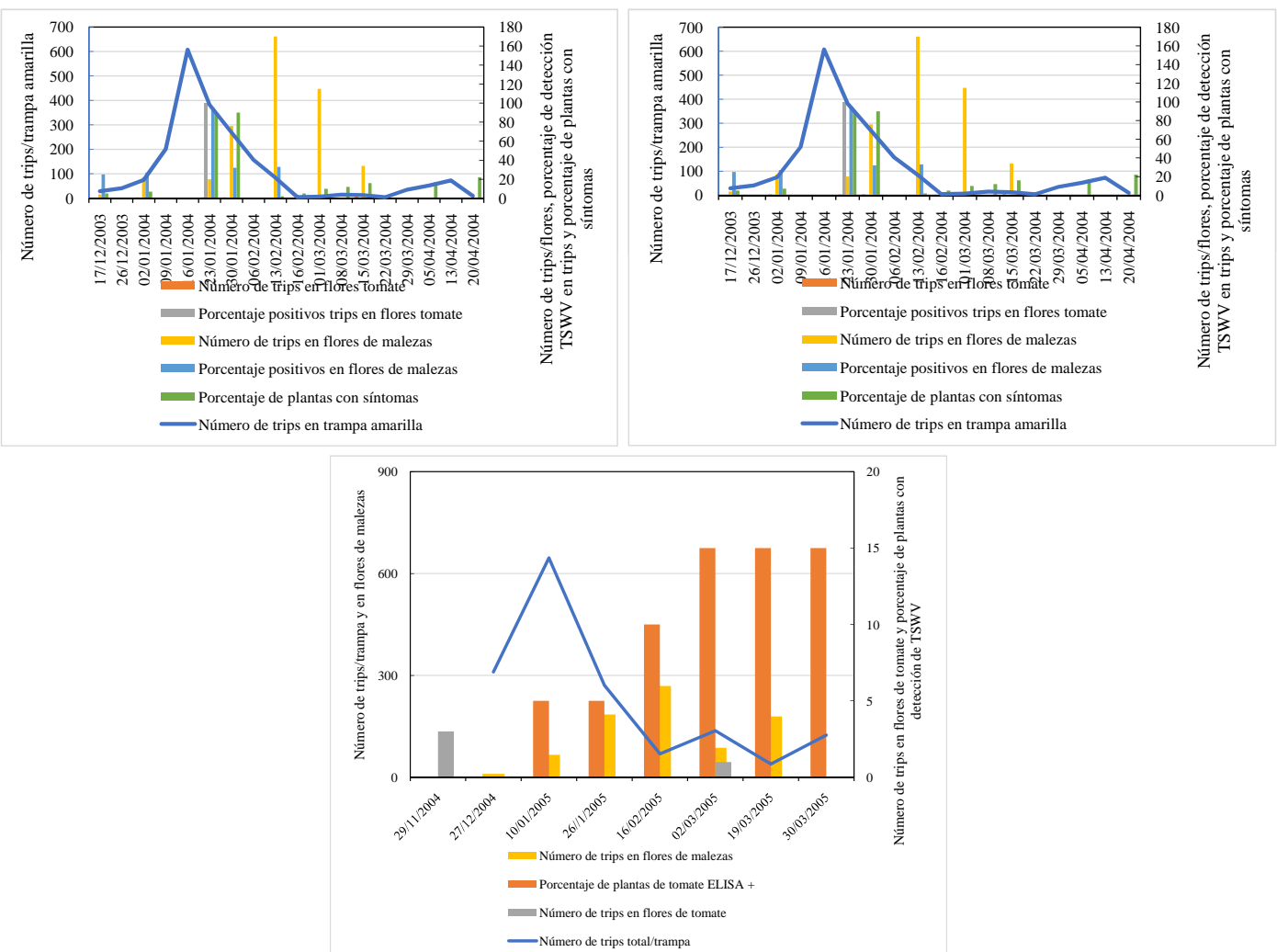

Figura 80. Evolución de la colecta de trips en flores de tomate, malezas, captura en trampas amarillas y detección de TSWV en plantas y trips en tres cultivos de tomate bajo invernáculo en INIA Las Brujas en el período 2003-2005.
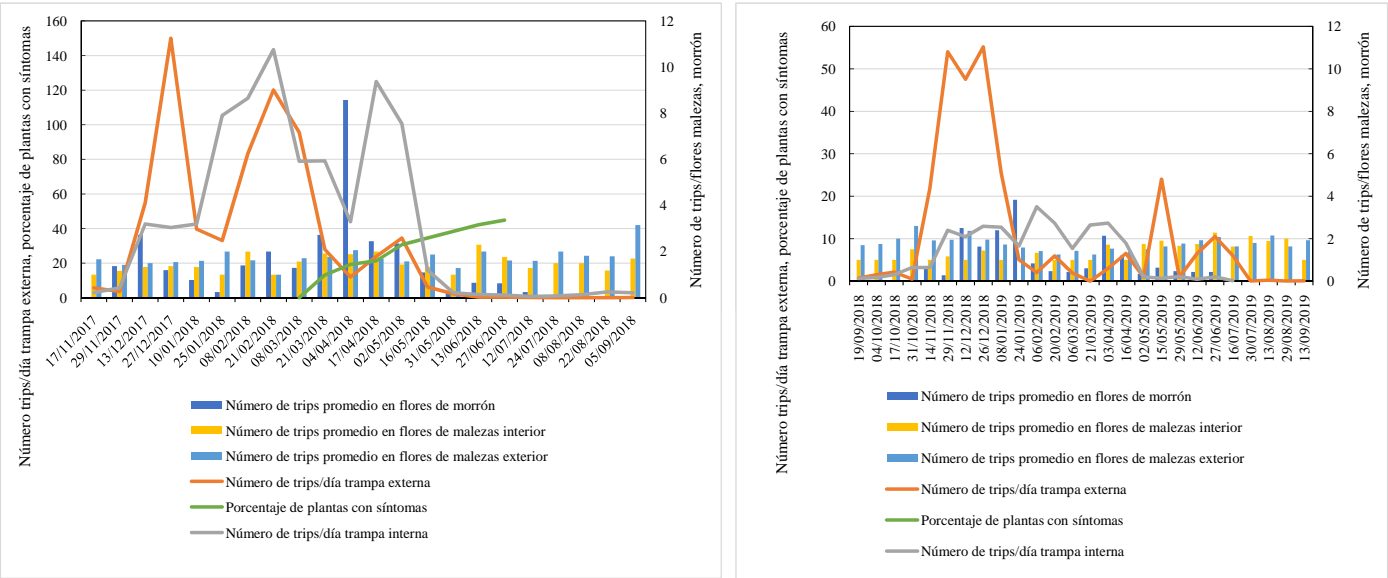

Figura 81. Evolución de la colecta de trips en flores de morrón, malezas (número promedio de diez flores y de todas las especies con individuos en sus flores), captura en trampas amarillas (dentro y fuera del invernáculo) y porcentaje de plantas con síntomas de peste negra (sobre un total de 1080 plantas) en un cultivo de morrón en Canelón Chico, período 2017 2019. 


\section{MANEJO}

Como ocurre con todas las enfermedades a virus de vegetales una vez que el cultivo está infectado no existen medidas curativas para aplicar, por lo tanto, el manejo deberá ser siempre preventivo, eficaz y sostenible a la vez, teniendo como objetivo la convivencia con niveles bajos de la enfermedad (de Ávila, 2007, citado por Dal Bo, 2011). Para ello es necesario integrar una serie de medidas basadas en el conocimiento del vector y de la enfermedad, complementando medidas fitosanitarias, culturales, resistencia genética y aplicaciones de productos químicas, orgánicos y biológicos para el control del vector y/o promover procesos del huésped (Coutts et al., 2004; Jones, 2004; Jones et al., 2004). Es importante enfatizar en la integración de medios, las fallas o errores cometidos en un aspecto menor puede derivar en la pérdida total del cultivo.

El manejo deberá estar dirigido en primera instancia a disminuir las fuentes de inóculo interno y externo y ser aplicado en etapas tempranas de la propagación del virus.

Además de los aspectos económicos, se deberán tener en cuenta la estabilidad en el tiempo de las medidas (p.ej. productos insecticidas que generan resistencia o afectan al agroecosistema, resistencia genética mal manejada que se quiebra, etc.) y los posibles efectos negativos sobre el ambiente y la salud.

Varios trabajos demuestran la efectividad del manejo integrado en reducir el impacto de TSWV en cultivos de morrón, lechuga, tabaco y tomate (Culbreath et al.,1999; Pappu et al., 2000; Riley y Pappu, 2000; 2004; Csinos et al., 2001; Momol et al., 2001; McPherson et al., 2003; Jones, 2004; Diaz-Perez et al., 2007; Nischwitz et al., 2008) y existen revisiones del tema para diversos cultivos de importancia económica muy recomendables (Cullbreath et al., 2003; 2010; Jones, 2004; 2006; Pappu et al., 2009).

Como se ha descrito, dado que para que ocurra la enfermedad en un cultivo, este debe ser inoculado por un insecto vector infectado, para prevenirla tendremos que actuar a diferentes niveles sobre el vector y el huésped, apuntando a los puntos vulnerables del ciclo y con el mayor número de formas diferentes (Jones, 2004; 2006).

Sobre el vector podemos disminuir su población, evitar que se vuelva infectivo, impedir el ingreso al cultivo y, como última barrera, combatirlo dentro de este. De todas ellas, la más eficaz es evitar que el insecto se vuelva infectivo, puesto que su presencia como plaga es el menor de los males y, por el contrario, la menor probabilidad de éxito la tendremos combatiéndolo dentro del cultivo.

Desde el cultivo, quizás la medida más efectiva es la resistencia genética. Si bien esta nos permite mayor flexibilidad en el uso de las otras medidas, no las descarta. Dada la capacidad de estos virus de generar variantes, si permitimos altos niveles de infección aumentamos las chances de generar aislados que superen los genes de resistencia.

También se han reportado los beneficios de la aplicación de productos que estimulan los mecanismos intrínsecos de resistencia del huésped. 
Otra estrategia que involucra al cultivo huésped es la de manejar la fecha de trasplante separándola en el tiempo de cultivos anteriores, y su localización a una distancia y posición respecto al sentido del viento desde probables fuentes de inóculo.

Muchos son los factores que dificultan el éxito de estas medidas. Pappu etal. (2009) mencionan al amplio y superpuesto rango de huéspedes de los orthotospovirus, la emergencia de aislados que quiebran la resistencia genética y, entre otros, la particular relación circulativapropagativa con el vector. Sin embargo, es mucho lo que se ha avanzado en el manejo de esta enfermedad fruto del conocimiento molecular del patógeno, de su interacción con la planta y el vector, y de la epidemiología de la enfermedad. Esto ha permitido la elaboración de modelos de predicción de ataques basados en la identificación de factores de riesgo de ocurrencia de epidemias y, por lo tanto, implementar tácticas de prevención según la situación (Pappu et al., 2009). Sin embargo, el impacto que tendrán las medidas dependerá de las condiciones particulares de cada cultivo, el momento del ciclo en que se hagan, y si son realizadas de forma correcta.

A continuación, realizaremos una revisión de la información disponible a nivel internacional complementada con la experiencia local de forma de proponer medidas adaptadas a nuestras condiciones.

\section{Monitoreo de trips y síntomas}

Para implementar un manejo integrado eficiente de esta enfermedad es imprescindible hacer un seguimiento de la presencia y evolución del vector, así como de los síntomas en el cultivo y la vegetación asociada. Esto nos permitirá seleccionar y llevar a cabo acciones preventivas y a la vez evaluar los riesgos y la efectividad de las medidas adoptadas.

El uso de trampas cromáticas pegajosas ubicadas en lugares estratégicos nos brindará información acerca del número de adultos que se movilizan durante el período de captura (Figura 82). La selección del color dependerá del interés, se conoce la preferencia de $F$. occidentalis por el color azul brillante, sin embargo, también se obtienen buenos resultados con trampas de color amarillo, las que tienen la ventaja de capturar además pulgones y mosca blanca (Mouden et al., 2017) e incluso, comparativamente ha mostrado mayor captura que la azul en algunas experiencias nacionales (cuadro 15).

Esta herramienta de monitoreo ha sido mejorada con la adición de sustancias que funcionan como atrayentes lo cual aumenta las capturas y brindan la posibilidad de desarrollar métodos de control como el de "attract and kill", trampeo masivo y "push-pull" lestímulodisuasión) (Davidson et al., 2007; Abdullah et al., 2015). Su utilidad en el manejo de peste negra es principalmente en el seguimiento de las primeras migraciones al cultivo (Arnó et al., 1995). 

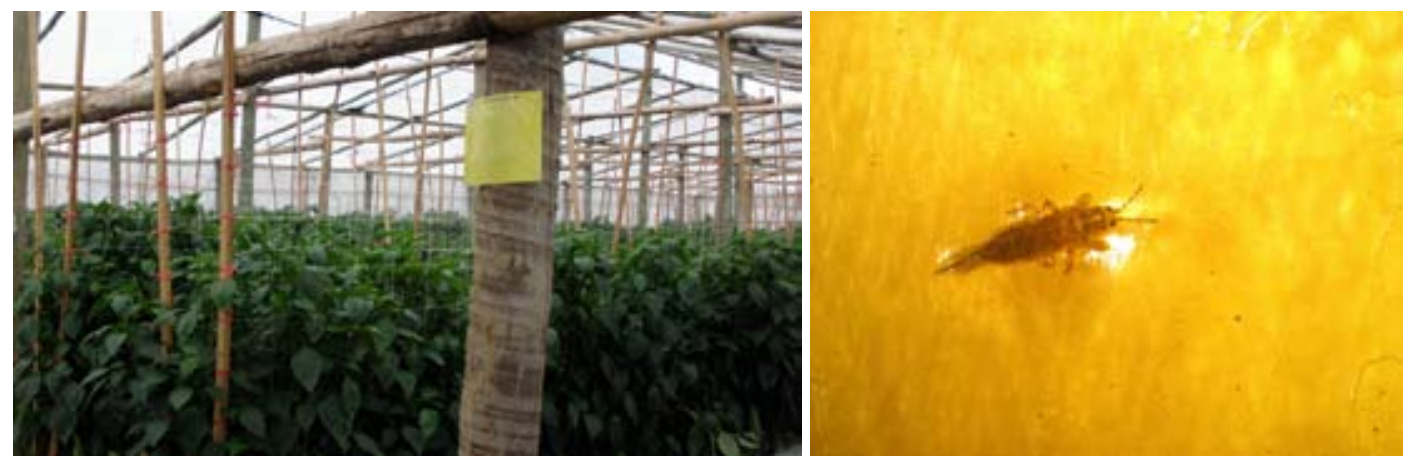

Figura 82. Trampas amarillas pegajosas para monitoreo de la evolución del número de adultos. Fotos D. Maeso.

También es importante registrar el número de trips presentes en flores del cultivo ya que será un indicador de la instalación y reproducción en el mismo, así como en la vegetación espontánea, como indicativo de su influencia en la epidemia, y que puede no guardar relación con la captura en trampas o estar diferido en el tiempo (Figura 83). Una de las formas para llevarlo a cabo es mediante el golpeo de un determinado número de flores sobre una superficie blanca, manteniendo constante el número de flores examinadas en las visitas es posible estimar la evolución del insecto durante la temporada (Figura 84). Este procedimiento tiene la ventaja de que este insecto tiene preferencia por flores frente a hojas y es más sencillo de realizar que la búsqueda de trips en hojas (Arnó, et al., 1995).
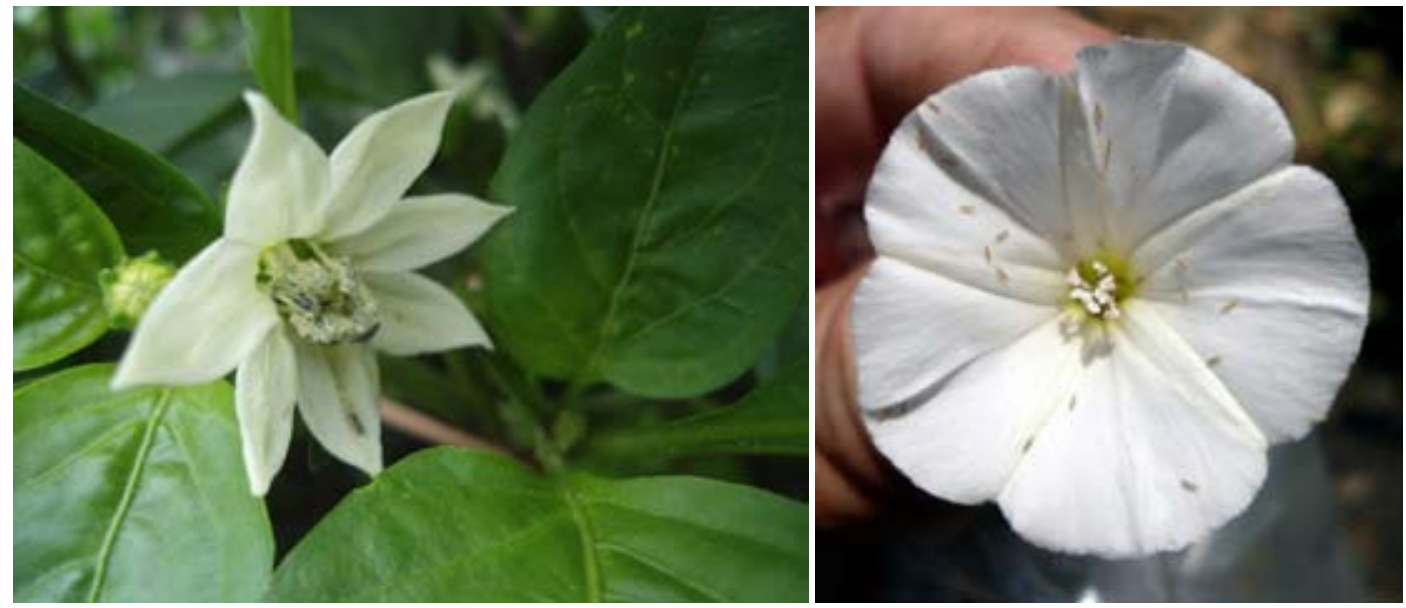

Figura 83. Trips en flores de morrón y corregüela. Fotos D. Maeso. 


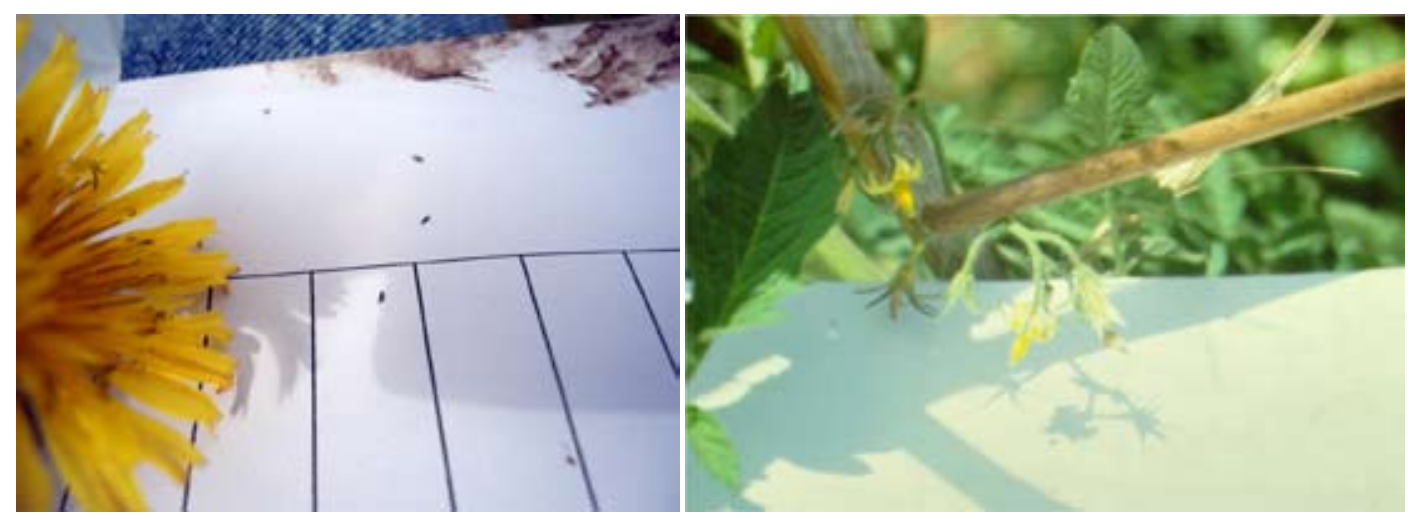

Figura 84. Extracción por golpeo de flores en superficie clara. Fotos D. Maeso

La presencia del insecto es muy utilizada para definir acciones en cuanto a su control como plaga. Al respecto, se han definido valores que difieren en los estados fenológicos (disminuyen a medida que avanza desde floración a fruto) y cultivos (se toleran números mayores en morrón y berenjena que en tomatel y que son complementados con el monitoreo de enemigos naturales (Reitz y Funderburk, 2015). Como ya se mencionó, muchas veces estos valores no están asociados con la capacidad trasmisora por lo que es recomendable verificarla. Si bien existen métodos de análisis de laboratorio, una forma sencilla que puede ser usada por el productor es la instalación de plantas de petunia dentro del cultivo, como ya fuera descrita en el texto (Allen y Matteoni, 1991). Estas plantas son sumamente atractivas para los trips y desarrollan lesiones características a los 2-3 días de ser infectadas. Las lesiones no son sistémicas por lo que no implica riesgos de propagar al virus (Figura 34).

También, es necesario realizar un seguimiento del avance de la enfermedad, examinando al cultivo para detectar plantas enfermas en forma temprana. Si bien, como ya se mencionó, las plantas infectadas pueden permanecer latentes varios días, la magnitud, localización y evolución de su presencia nos ayudará para verificar la eficacia de las medidas tomadas, caracterizar el origen del ataque y tomar medidas adicionales.

\section{Eliminación de fuentes de virus y trips entre cultivos}

\section{Manejo de la vegetación en los alrededores de los invernáculos.}

Un punto clave en la prevención de la enfermedad es evitar la existencia de fuentes de inóculo primarias, o sea vegetación hospedera de orthotospovirus y a la vez capaces de albergar trips. En ese sentido importa conocer su cantidad, la duración de su ciclo, la proporción de plantas infectadas o con síntomas, si se tratan de cultivos o vegetación espontánea, la distancia al cultivo comercial, la presencia o no de obstáculos entre ellos (barreras físicas o plantas no huéspedes) y la orientación al viento, entre otros (Jones, 2004).

Como hemos visto en los apartados anteriores el rango de hospederos de trips y virus es muy amplio, por lo que la lista y la abundancia de estas plantas es tal que imposibilitaría su eliminación total. Por lo tanto, desde el punto de vista práctico debemos limitar el alcance 
de esta medida. Para las malezas existentes en el exterior se debería delimitar un área de seguridad cercana al invernadero y actuar preferentemente en los momentos desde que finaliza un cultivo hasta que inicia el siguiente. No es necesario eliminarlas completamente (salvo cuando muestran síntomas de la enfermedad) sino prevenir que florezcan dado que las flores son el lugar preferido por el vector. Eso se lograría realizando cortes periódicos en una franja cercana al invernáculo, dejando la eliminación exhaustiva en cambio para el interior de éste. No es aconsejable la aplicación de herbicidas para malezas de hoja ancha ya que pueden producir efectos fitotóxicos al cultivo, ya sea por deriva en la aplicación o por su volatilización, además de no ser completamente efectivos a nuestros fines (Clift, 2000). Por otro lado, es necesario mantener las inmediaciones del invernáculo cubiertas por un tapiz vegetal bajo que impida la formación de barro. La tarea de prevenir la floración mediante corte se dificulta con cierto tipo de malezas como lo son los tréboles, muy frecuentes en nuestras condiciones los cuales son muy preferidos por el vector.

Esta tarea es ineludible y deberá realizarse muy exhaustivamente en las instalaciones dedicadas a la producción de plantines en las que debe prestarse especial atención en la cubierta vegetal que crece debajo de las almacigueras.

Un aspecto para considerar es que el corte debe ser reiterado y con anticipación al trasplante, pues, como vimos anteriormente, puede tener el efecto indeseado de facilitar la migración del vector hacia el cultivo al alterar su refugio.

Con la difusión del control biológico por conservación se aconseja dejar proliferar a la flora espontánea en el exterior con la finalidad de mantener y multiplicar enemigos naturales de plagas. La anterior recomendación podría contradecir este objetivo, sin embargo, por el momento lo principal en nuestra opinión es recolectar más información acerca de identidad, huéspedes, momentos de proliferación y hábitos de estos controladores para quizás en un futuro compatibilizar ambas metas.

Un aspecto para considerar en este apartado es cuál es la distancia necesaria a fuentes de infección para evitar la trasmisión. Los valores mencionados son muy diversos, desde pocos metros a $75 \mathrm{~m}$ dependiendo de la importancia de la fuente y la dirección del viento (Latham y Jones, 1996; 1997; Coutts et al., 2004; Jones 2004). Sin embargo, a los efectos prácticos el mayor efecto lo tendrán las fuentes más cercanas o dentro del cultivo.

En las siguientes figuras se muestran algunos ejemplos del manejo de malezas en el exterior del invernáculo realizados por los productores, como la aplicación de herbicidas en la pared externa complementada con el corte en las inmediaciones para privilegiar la presencia de gramíneas (Figura 85). No es recomendable dejar el suelo desnudo ya que se favorece la formación de barro, acumulando el agua de lluvia directa y acumulada desde los techos lo cual complica el tránsito de la maquinaria (Figura 86). Otro procedimiento es realizar cortes periódicos de forma de mantener la vegetación corta y evitar la floración de las malezas sin perder el tapiz verde (Figura 87). Sin embargo, existen algunas malezas de las mencionadas en esta publicación, como el trébol blanco que son difíciles de eliminar ya que su vegetación tan baja escapa a los cortes (Figura 88). 


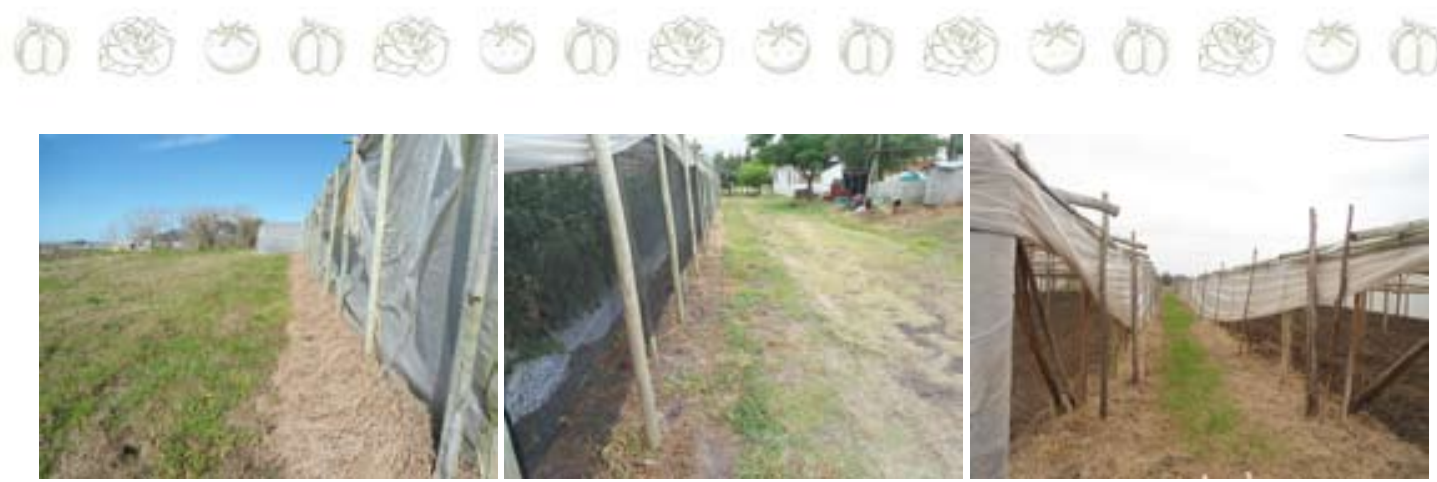

Figura 85. Control de malezas en la faja externa del invernáculo. Aplicación de herbicida junto a la pared y corte en la inmediación. Fotos D. Maeso.
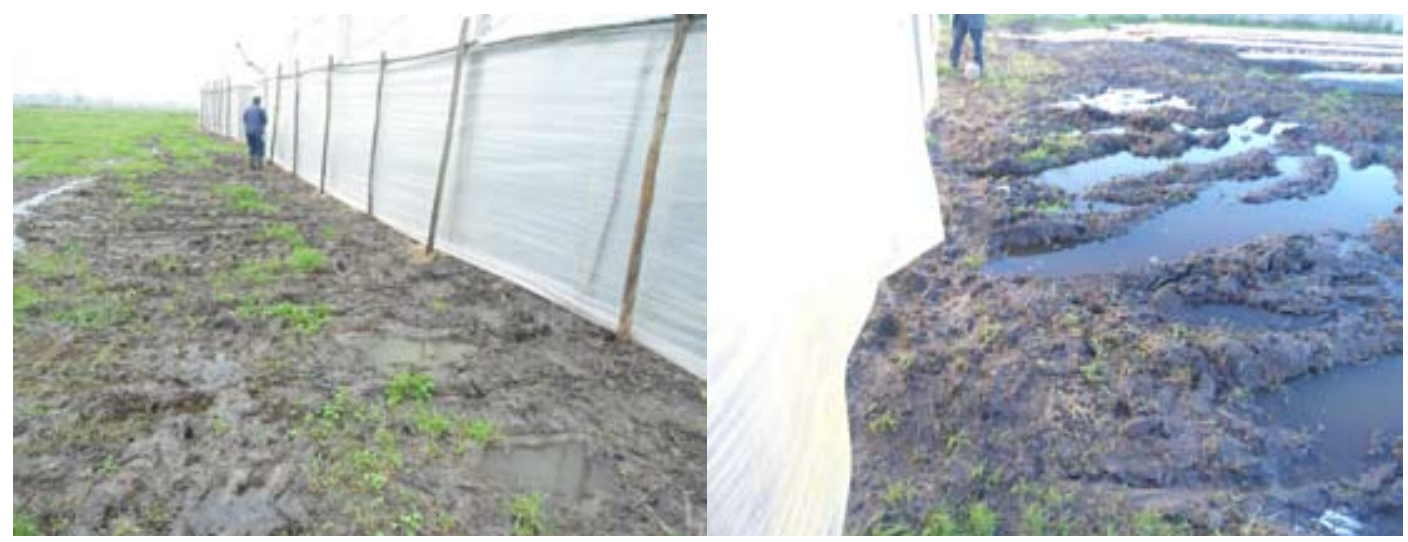

Figura 86. Problemas de encharcamiento provocados por dejar suelo desnudo alrededor de los invernaderos. Fotos D. Maeso

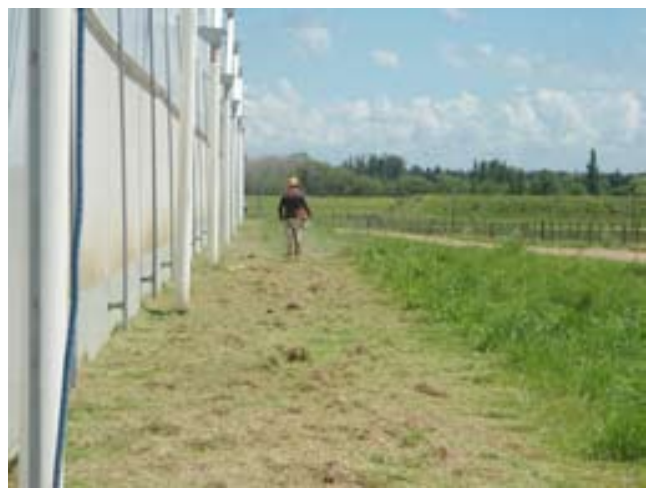

Figura 87. Corte de vegetación espontánea en las inmediaciones de los invernaderos. Fotos D. Maeso.

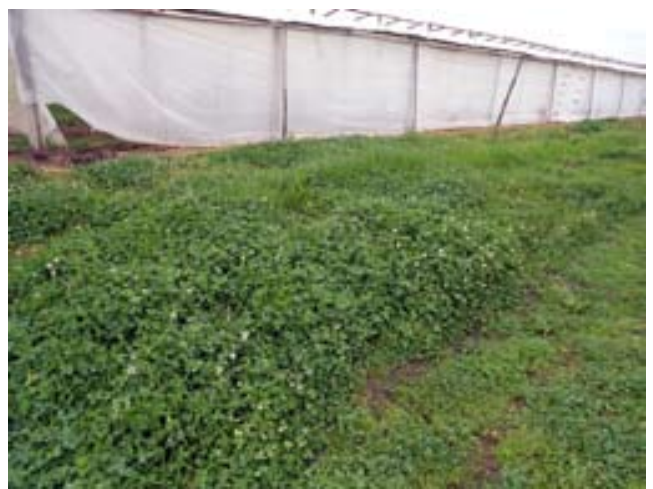

Figura 88. Presencia de trébol blanco en la inmediación de los invernáculos. Foto D. Maeso. 


\section{Manejo de las malezas y restos del cultivo en el interior}

Como se ha mencionado en los apartados anteriores, la presencia de malezas y plantas espontáneas entre estaciones dentro del invernáculo ayuda a cerrar el ciclo de la enfermedad, manteniendo al vector y al virus, recibiendo infección del exterior o desde los adultos que emergen de pupas del cultivo anterior. Es común que una vez finalizado el cultivo (junio, juliol el invernáculo continúe con restos y malezas hasta casi la preparación de la nueva estación (Figura 89) lo cual promueve la continuación de la enfermedad.

Por esa razón es muy importante el laboreo con retiro previo de los restos del cultivo anterior lo más próximo al final de este. El laboreo no solo actúa sobre la vegetación espontánea, sino que también tiene efecto sobre la permanencia de pupas. Es importante no solo quitar la parte aérea sino todo el material vegetal, ya que es costumbre solamente cortar la parte aérea y dejar los tocones que luego rebrotan o, también dejar los restos sobre la superficie (Figura 90). Respecto a esto último pudimos comprobar la ocurrencia de un ataque temprano casi total en un cultivo trasplantado sin quitar los restos (Figura 91).

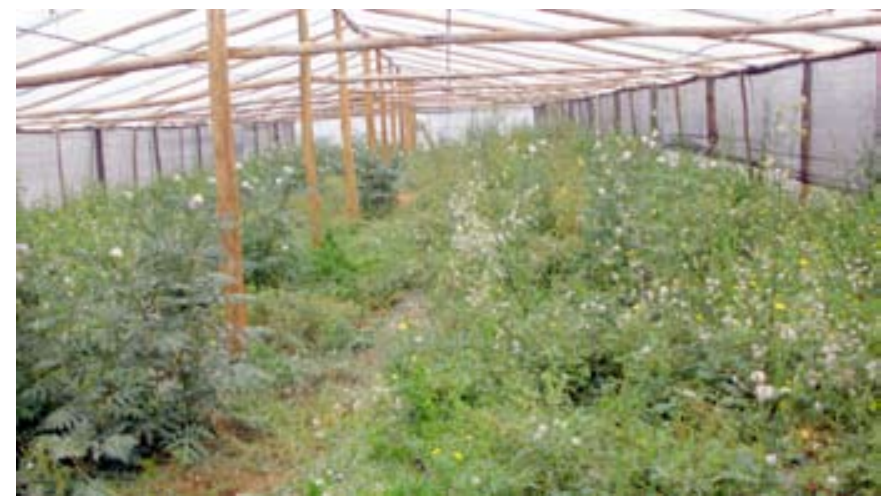

Figura 89. Vegetación espontánea y plantas de cultivo abandonado al final de estación. Foto D. Maeso
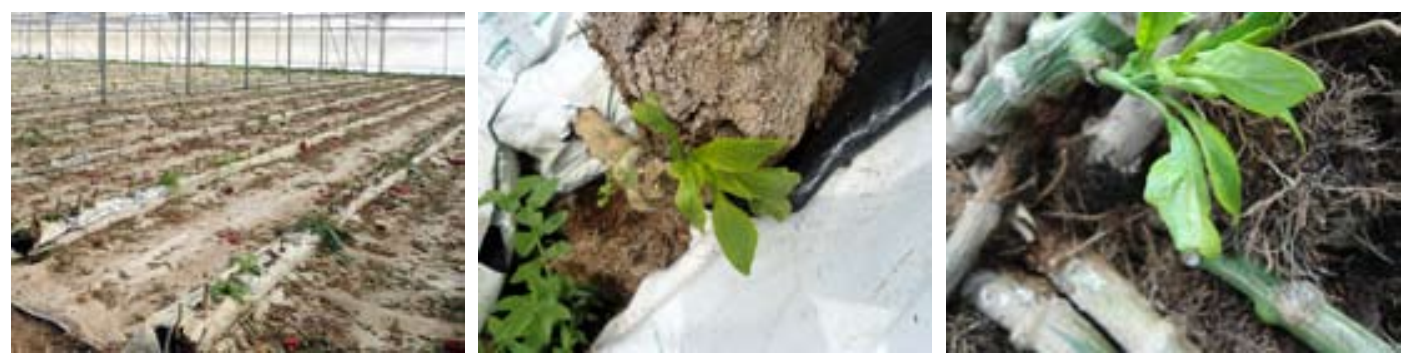

Figura 90. Remanentes luego de quitar el cultivo anterior. Izquierda, tocones, centro tocón con rebrote con síntomas en su lugar, derecha rebrote en depósito de restos cercano al invernáculo. Fotos D. Maeso. 


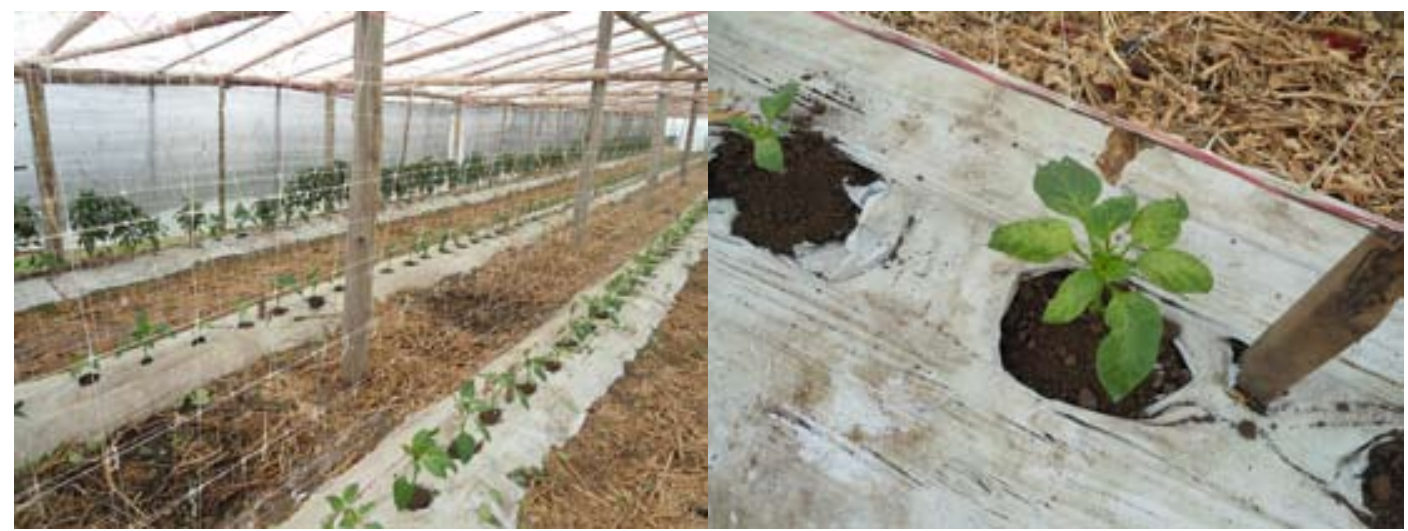

Figura 91. Cultivo trasplantado dejando restos del cultivo anterior en la entre fila afectado por peste negra tempranamente. Fotos D. Maeso.

Luego de realizar el laboreo es conveniente la siembra de un abono verde el cual debe cubrir completamente la superficie para evitar el crecimiento de malezas o plantas espontáneas de frutos caídos (Figura 92).

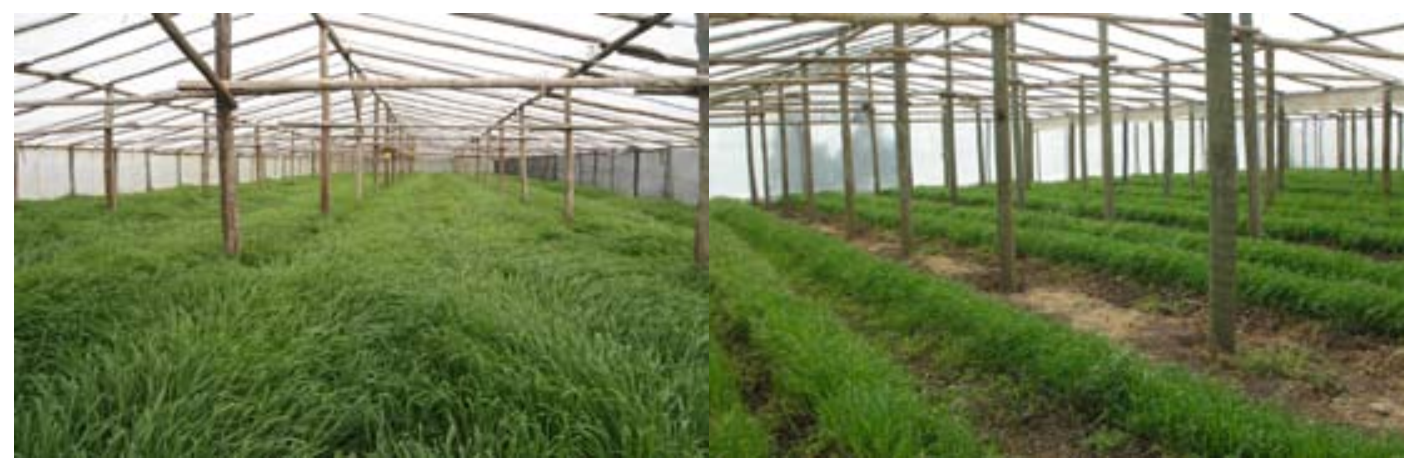

Figura 92. Realización de abonos verdes entre cultivos. Izquierda buen ejemplo, derecha solo en la fila, nótese la vegetación espontánea en postes. Fotos D. Maeso.

Una medida beneficiosa para la sanidad en general y para el combate de malezas es la solarización. Esta consiste en la cobertura durante el verano con plástico trasparente totalmente la superficie del suelo ya preparado para la plantación. Si bien no es compatible con la realización de cultivos de verano en la zona sur, es una alternativa mejor que perder una plantación por problemas sanitarios. En nuestra opinión es una medida que debería realizarse de forma preventiva y rotativa en una parte de los invernáculos del establecimiento de forma ir eliminando problemas sanitarios residuales (Figura 93).

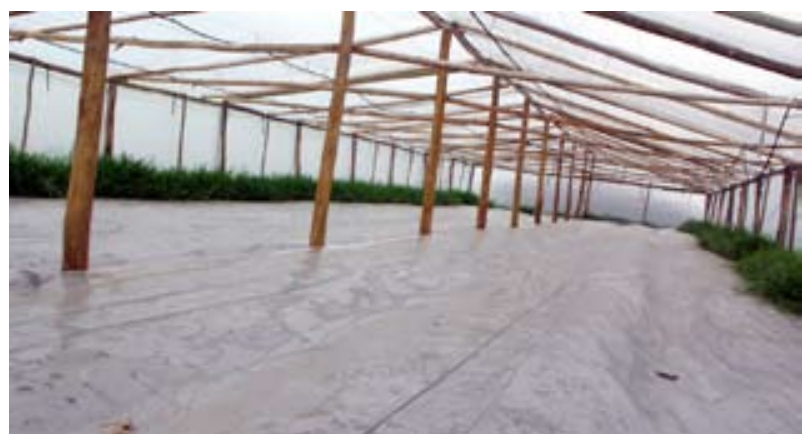

Figura 93. Solarización en invernáculos dedicados a cultivos hortícolas de verano. Foto D. Maeso. 


\section{Intervalo entre cultivos y rotaciones}

En general, en regiones con cultivos intensivos de hortalizas todo el año, las epidemias de peste negra causan daños severos cuando se siembran cultivos sensibles secuencialmente como lechuga, morrón y tomate en proximidad, cuando no se levantan rápidamente una vez finalizado su ciclo, o no se realiza un buen control de malezas y plantas espontáneas. En esas situaciones, las plantas están sometidas desde su estado juvenil más vulnerable a un continuo bombardeo de trips infecciosos (Latham y Jones, 1996: 1997).

Se ha determinado que en muchos cultivos las fechas de plantación tempranas reciben la mayor parte de los vectores invernantes, ya sea desde malezas o de pupas que quedaron en restos de cultivos anteriores o en el suelo (Cullbreath, 2011).

En el caso de los cultivos protegidos, la situación se ve agravada porque en el interior se mantienen temperaturas favorables para la permanencia y desarrollo de altos niveles de trips. Además, como el área disponible es restringida y los invernáculos se construyen cercanos, la enfermedad puede expandirse rápidamente (Jones, 2004).

Algo similar puede ocurrir en la producción de almácigos para la venta. En ese caso las plantas están expuestas en su estado más sensible, se hacen siembras secuenciales, están acumuladas en ambientes protegidos y, generalmente la infección no se evidencia hasta que las plantas se llevan a su lugar definitivo.

En maní en el sudeste de EE. UU. se utiliza un índice de riesgo para determinar la fecha de plantación y evitar el ataque de la enfermedad (Cullbreath et al., 2011). La selección de la fecha se basa en la determinación de una ventana según los cambios en la población de trips provenientes de malezas o plantas guachas temprano en la estación (Chamberlin et al., 1993; Hurt et al., 2005) y factores ambientales como lluvia y temperatura.

De acuerdo con nuestra experiencia el intervalo entre cultivos debe ser lo suficientemente largo como para evitar que los adultos que emergen de las pupas del cultivo anterior, pero no tanto que la fecha de trasplante coincida con la migración de adultos desde el exterior.

\section{Orientación y diseño de las filas}

En cultivos extensivos como maní se ha observado que el diseño de la plantación influye en la trasmisión de TSWV afectando el reconocimiento de las plantas por los trips en su migración. Según Cullbreath (2011) y Hurt et al. (2005), los cultivos de maní realizados a mayor densidad tienen menor riesgo de daño y probabilidad de infección que aquellos más distanciados. Esta estrategia se basa en que la enfermedad tiene un ciclo único de infección y que al tener un mayor número de plantas las sanas compensarán las pérdidas por la enfermedad. En el caso de los cultivos hortícolas a los que nos estamos refiriendo esa alternativa es poco viable.

Respecto a la orientación de las filas para impedir el ingreso de la migración de vectores por viento, de acuerdo con nuestra experiencia no existe una recomendación única ya que 
todo dependerá del diseño particular y de la posición de los invernáculos en cada predio, lo cual alterará el proceso. La estrategia es que sin limitar la ventilación se debe evitar la migración de los vectores desde fuentes de inóculo del exterior.

\section{Distancias entre cultivos}

El efecto de la distancia entre cultivos sensibles ha sido más estudiado en cultivos al aire libre. Según Coutts et al. (2004) la distancia de aislamiento recomendada depende de la duración del cultivo, requiriendo mayores distancias los cultivos de ciclo más largo lepidemias policíclicas), de la magnitud y las características de la fuente de inoculo y la dirección del viento, variando los valores desde 25 a $100 \mathrm{~m}$. Estas distancias son teóricas y muchas veces inaplicables en las explotaciones hortícolas de Uruguay. Si embargo debemos tener en cuenta que los valores se reducen cuando se aplican otras medidas de manejo complementarias (mallas, cortinas, poca incidencia de la enfermedad y buen control de huéspedes alternativos).

\section{Barreras físicas}

Dentro de esta medida de manejo debemos distinguir entre barreras vivas o artificiales.

Existen varios trabajos en los que se demuestra el efecto beneficioso de la plantación de fajas de cultivos no huéspedes como repollo, de ancho variable (p. ej. $15 \mathrm{~m}$ ) en la prevención de ataques de peste negra en cultivos sensibles (Cho et al., 1987; Coutts et al., 2004). Con esta medida se disminuyó el tradicional gradiente de acuerdo con la distancia desde focos primarios en cultivos de lechuga y morrón a favor del viento, transformándolo en pequeños focos derivados de trasmisión secundaria (Gitaitis et al., 1998; Groves et al., 2001). Las barreras con cultivos no huéspedes son efectivas enlenteciendo la infección, los trips vuelan desde las plantas foco, se establecen en el cultivo no huésped, lo colonizan y no llegan al cultivo sensible o, cuando lo hacen, su progenie ya no está infectada.

Boiteau y Vernon (2001) presentan una completa revisión del tema, cubriendo también el uso de barreras artificiales y las implicancias en cuanto a distancia al cultivo, altura, interacción con la acción del viento y tipo de insecto en particular, factores que influyen tanto en la eficiencia de la barrera en el control como en su impacto sobre el cultivo.

Con un fundamento similar se han usado los "cultivos asociados" (inter-cropping) mezclando por ejemplo maíz con tomate o morrón, lo cual dificulta la diseminación del vector al cultivo sensible y provee a la vez de una protección para el viento (Ramkat et al., 2007). Esta modalidad no se ha difundido mucho comercialmente debido a que, si bien reduce la incidencia de la enfermedad, también disminuye los rendimientos por la competencia y el sombreado producido por el maíz, por lo que se utiliza fundamentalmente en determinados tipos de producción orgánica. 
El uso de mallas para impedir la entrada de insectos vectores en cultivos protegidos se ha difundido mucho en los últimos años (Figura 94) y varios son los trabajos publicados en el tema (Bell y Baker, 2000; Lacasa et al., 1994, Díez et al., 1999). Se cuenta con información experimental local que muestra los beneficios de esta herramienta disminuyendo la presencia de trips, con algunas consideraciones en cuanto a condiciones ambientales en el interior del invernadero (Buenahora et al., 2009). Por esa razón es importante controlar el aumento de temperatura y humedad relativa interna lo cual puede traducirse en mayor incidencia de enfermedades y otros desórdenes.

Al respecto, se deberán considerar algunos factores que permitirán obtener los mejores resultados de esta importante inversión. En primer lugar, se debe tener en cuenta la dimensión de los orificios, ya que queremos evitar el ingreso de insectos tan pequeños como son los trips. Para ello los orificios deben ser menores a 0,19 mm (Buenahora, 2014), o sea 16$20 \times 10$ hilos por $\mathrm{cm}^{2}$, que es menor a los 50 hilos por pulgada utilizados para otros insectos (Figura 95). Esto puede ocasionar potenciales problemas de ventilación y luminosidad.

Sin embargo, las precauciones tomadas en la selección de la malla se pierden sino se complementan con cambios en la forma de trabajo fundamentales para invernaderos con malla. En ese sentido debemos tener en cuenta que ésta no impide el ingreso de insectos por descuidos, ya sea dejando vías de ingreso libres (orificios, incorrecto cerrado) o por el trasporte de vectores en vestimentas, plantas, implementos, etc. Por esa razón es importante que el enmallado del perímetro y aberturas cenitales sea complementado con la construcción de puertas dobles de ingreso (Figura 96). Es fundamental que el invernadero esté protegido con la malla en el período inmediatamente antes y después del trasplante para impedir la migración de trips al cultivo. Una estructura enmallada mal manejada en lugar de prevenir la entrada de vectores se convierte en un perfecto refugio de éstos con condiciones ambientales ideales y fuera de la acción de sus enemigos naturales.
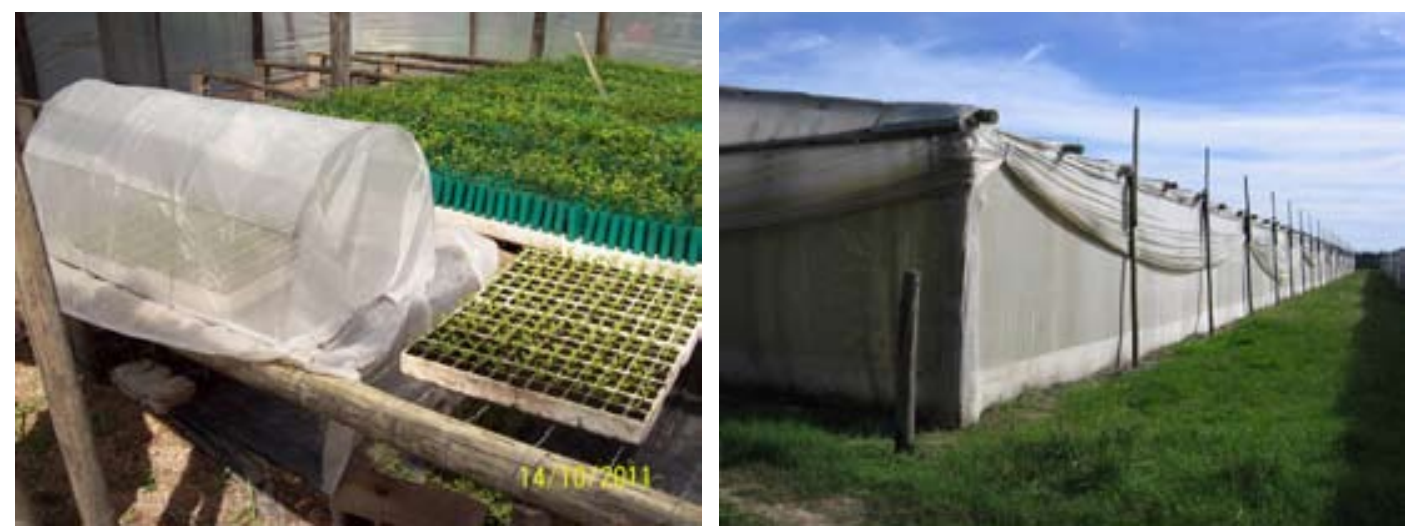

Figura 94. Ejemplos del uso de mallas en almácigos e invernáculos. Fotos D. Maeso 


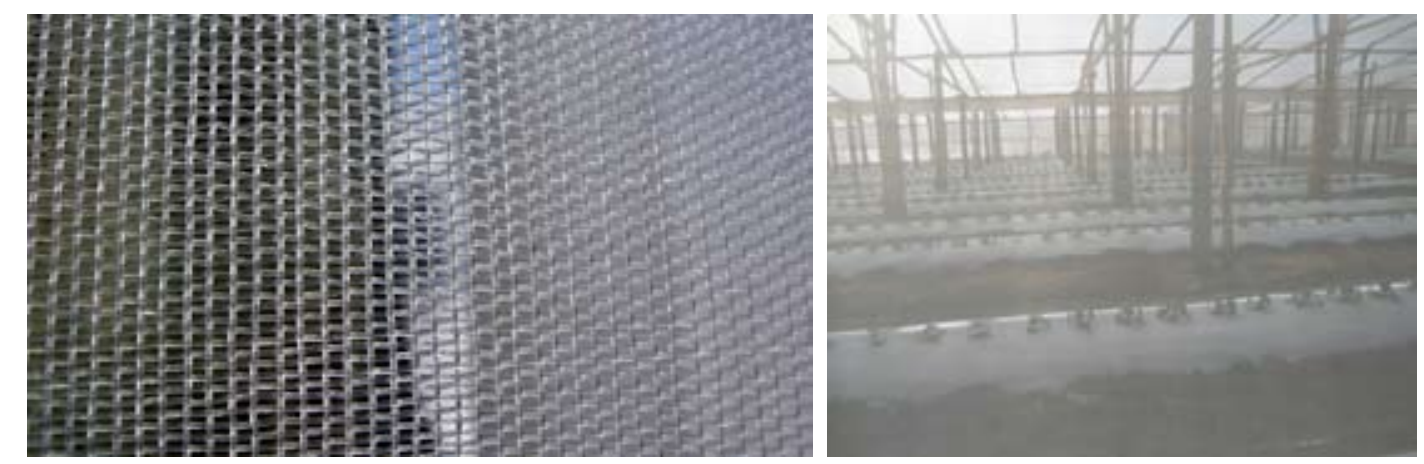

Figura 95. Tipo de malla utilizada para evitar ingreso de vectores. Fotos D. Maeso
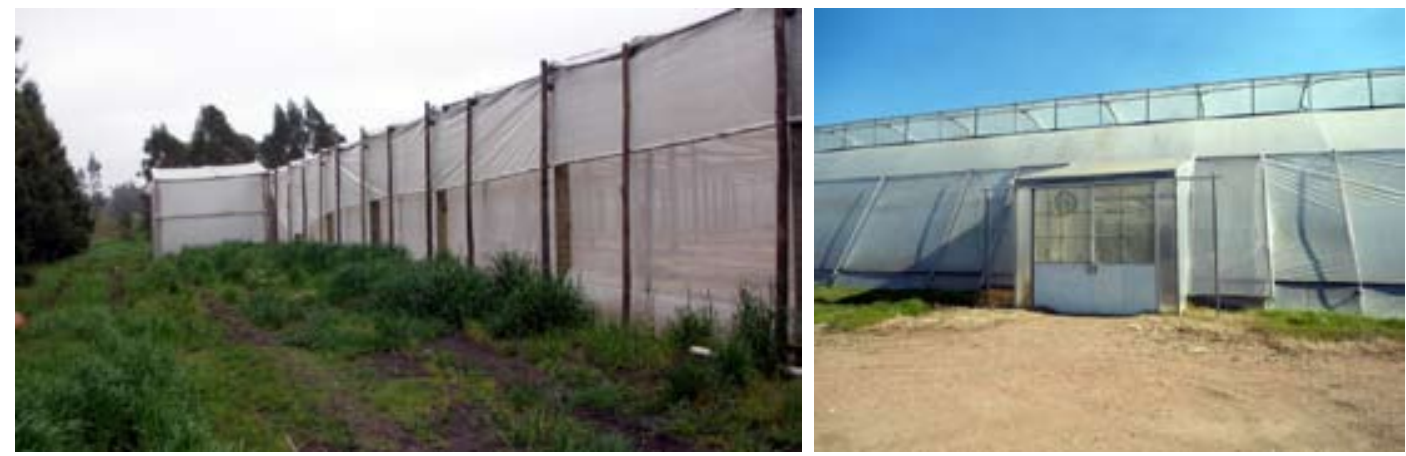

Figura 96. Diferentes diseños de doble puerta de entrada en invernáculos con malla. Fotos D. Maeso

Durante las temporadas 2011-2012, 2012-2013 y 2013-2014 hemos evaluado el efecto del uso de mallas perimetrales anti-insectos para la prevención de peste negra en cultivos de morrón en invernaderos localizados en Canelón Chico, departamento de Canelones. En ese trabajo se registró semanalmente la captura de trips en cuatro trampas amarillas pegajosas ubicadas en el interior y cuatro en el exterior de los invernáculos en cada lado. En la Figura 97 se muestran los resultados de las evaluaciones correspondiendo al promedio de todas las trampas y corregidos como "trips/día” (número registrado dividido entre los días entre colectas). Como se puede apreciar existieron diferencias en el número de trips capturados en el exterior de ambos invernáculos y en todo caso el número interno fue menor sin importar si existía malla perimetral o no. El efecto de la presencia de malla perimetral se notó en las temporadas 2012-13 y 2013-14 dado que en la temporada previa la instalación fue tardía y con algunos defectos en el aislamiento que se fueron mejorando. 

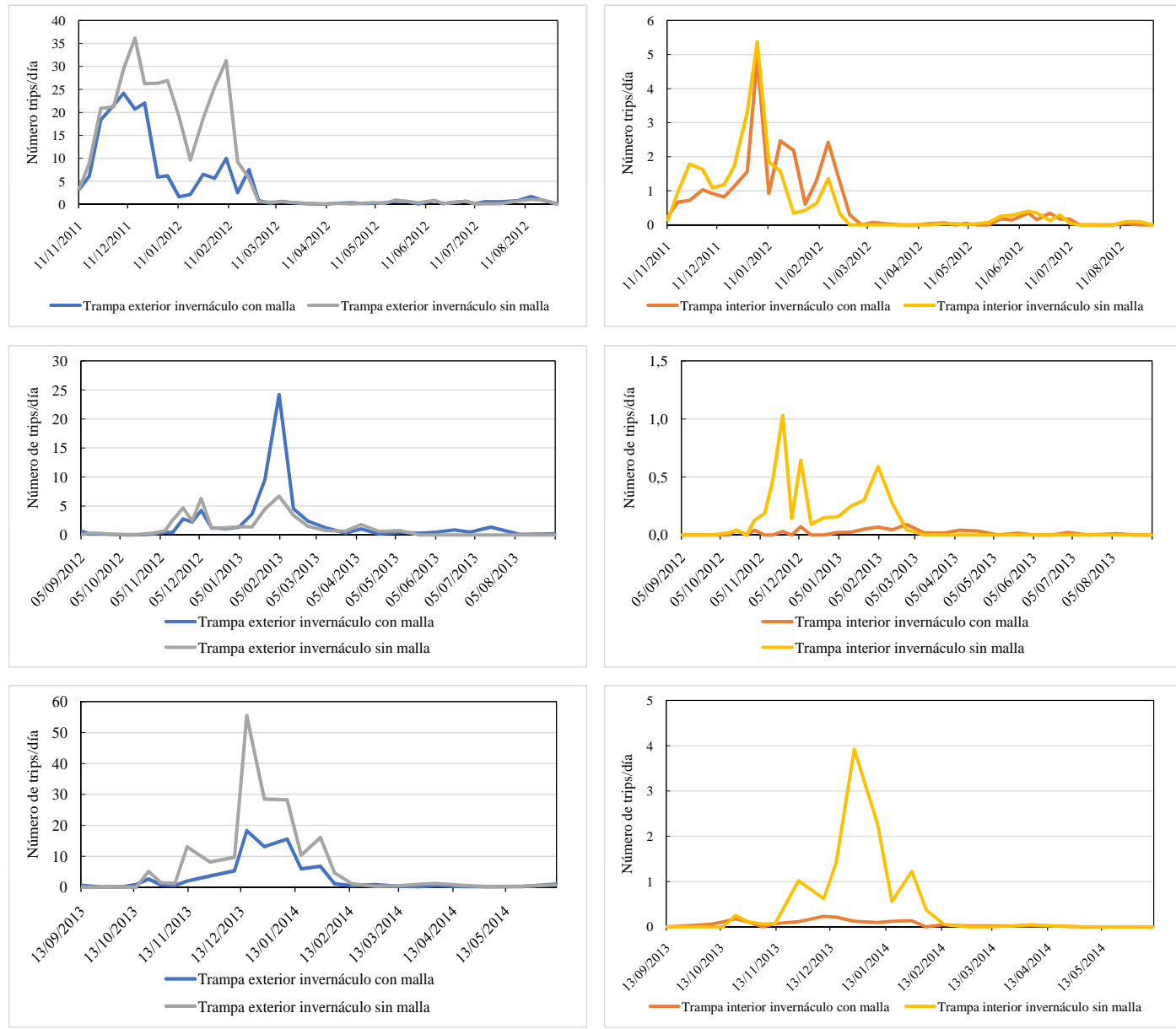

Figura 97. Número de trips/día (número total observado dividido entre intervalo en días entre capturas) capturados en trampas amarillas pegajosas ubicadas en el interior y exterior de invernáculos con cultivos de morrón en tres temporadas (2011-2014).

También durante ese estudio se registró la presencia de síntomas en 100 plantas distribuidas en cinco estaciones en dos invernáculos, uno con malla anti-insecto y doble puerta y otro sin ella con diseño tradicional (Figura 98) verificándose la infección con TSWV mediante DAS-ELISA.

123 

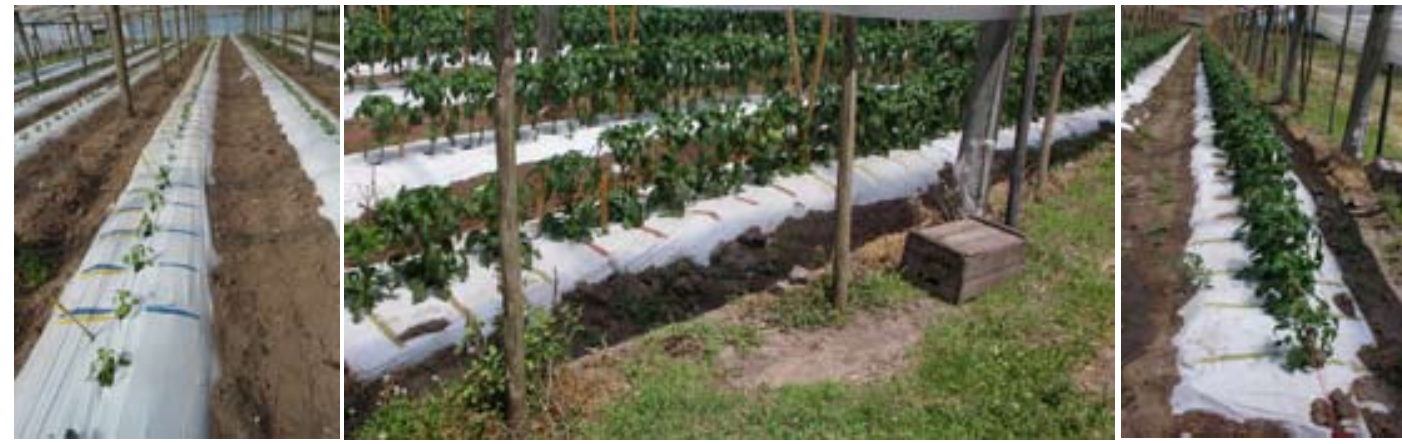

Figura 98. Vista de algunas de las estaciones con las plantas evaluadas en este experimento. Fotos D. Maeso

En la figura 99, se presenta la evolución del porcentaje de plantas con síntomas en dos de las tres temporadas estudiadas. Es importante recordar que la colocación de mallas en 2011 se hizo en forma tardía posterior al trasplante del cultivo, por lo que su efecto sobre la migración de trips al interior del invernáculo y la infección inicial derivada de ello no se logró, pero sin embargo su efecto se observó al reducir la ocurrencia de nuevas infecciones durante la temporada. El nivel bajo de presencia de síntomas en la temporada 2012-2013 no permite mayor análisis, a pesar de lo cual el avance de la enfermedad fue menor en el cultivo con malla perimetral.
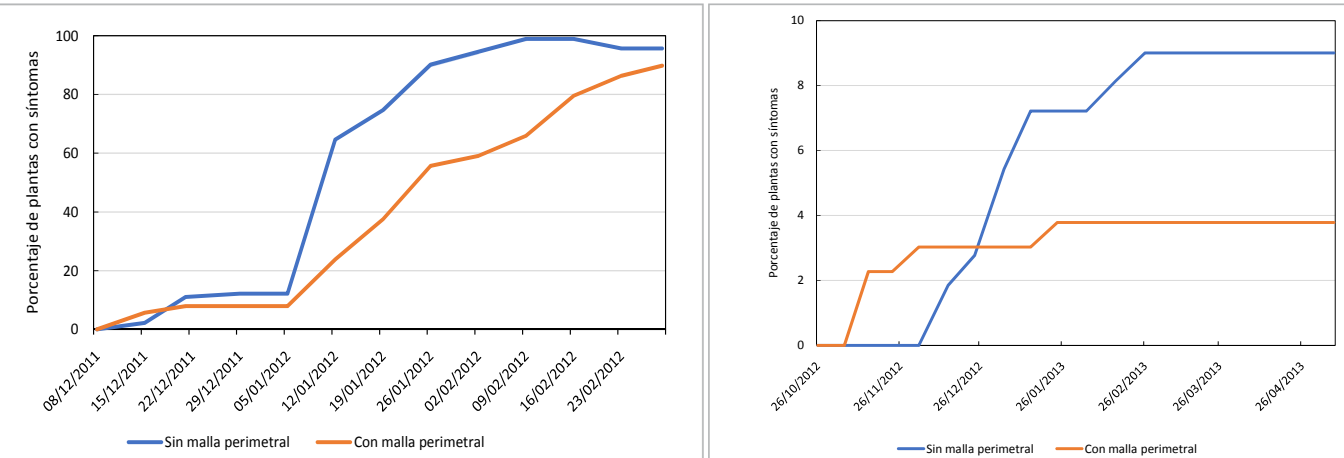

Figura 99. Evolución de la aparición de síntomas de peste negra en un cultivo de morrón realizados con o sin protección perimetral de malla anti-insecto.

\section{Medidas durante el cultivo}

\section{Confusión del comportamiento visual del vector}

Los trips encuentran a sus huéspedes a través de señales visuales y atraídos por los colores de sus flores. Son atraídos por las radiaciones en el rango del ultravioleta $(\sim 365 \mathrm{~nm})$ que les permite distinguir las flores y del amarillo-verde $(\sim 540 \mathrm{~nm})$ para localizar plantas (Matteson et al., 1992; Stukenberg et al., 2020). Frankliniella occidentalis prefiere flores blancas, celestes y amarillas con baja reflectancia (Antignus, 2000). 
Varios trabajos demuestran los beneficios de determinadas medidas que interfieren con el comportamiento visual del vector, entre ellas la distribución de trampas cromáticas pegajosas de forma masiva dentro del cultivo, los mulchs reflectivos y las cubiertas plásticas que filtran el espectro UV (ultravioleta) de luz (Reitz y Funderburk, 2015).

La influencia de diferentes colores sobre el comportamiento de trips es muy conocida, de esa forma se sabe que los colores azul brillante (principalmente), amarillo y blanco funcionan como atrayentes y por ello son recomendados en trampas de monitoreo. Esa capacidad de atracción también ha sido empleada para la captura masiva, no solo de trips sino también de otras plagas que son atraídas por igual gama de colores (pulgones, mosca blanca). Para ello se instalan superficies de color engomadas las cuales son reemplazadas periódicamente con las que se capturan a las plagas y se las desvía de las plantas del cultivo (Figura 100).

En nuestro país se han realizado algunos trabajos de evaluación de esta medida para mosca blanca (Bemisia tabaci) y trips (F. occidentalis) en la zona hortícola de Salto, en los que se encontró cierta disminución en la población de estas plagas y se recomienda la realización de estudios adicionales en cuanto a momento de colocación y de recambio de la superficie engomada (Buenahora et al. 2003). En los invernaderos del sur de España se recomienda la colocación de entre 5-10 trampas/1000 $\mathrm{m}^{2}$, con una antelación mínima de 6-7 días del trasplante, a una altura que acompañe el crecimiento del cultivo, distribuidas en los posibles lugares de entrada de vectores (doble puerta, ventilación cenital), nunca en el exterior y deben ser retiradas cuando se introducen enemigos naturales (Monserrat, 2006).
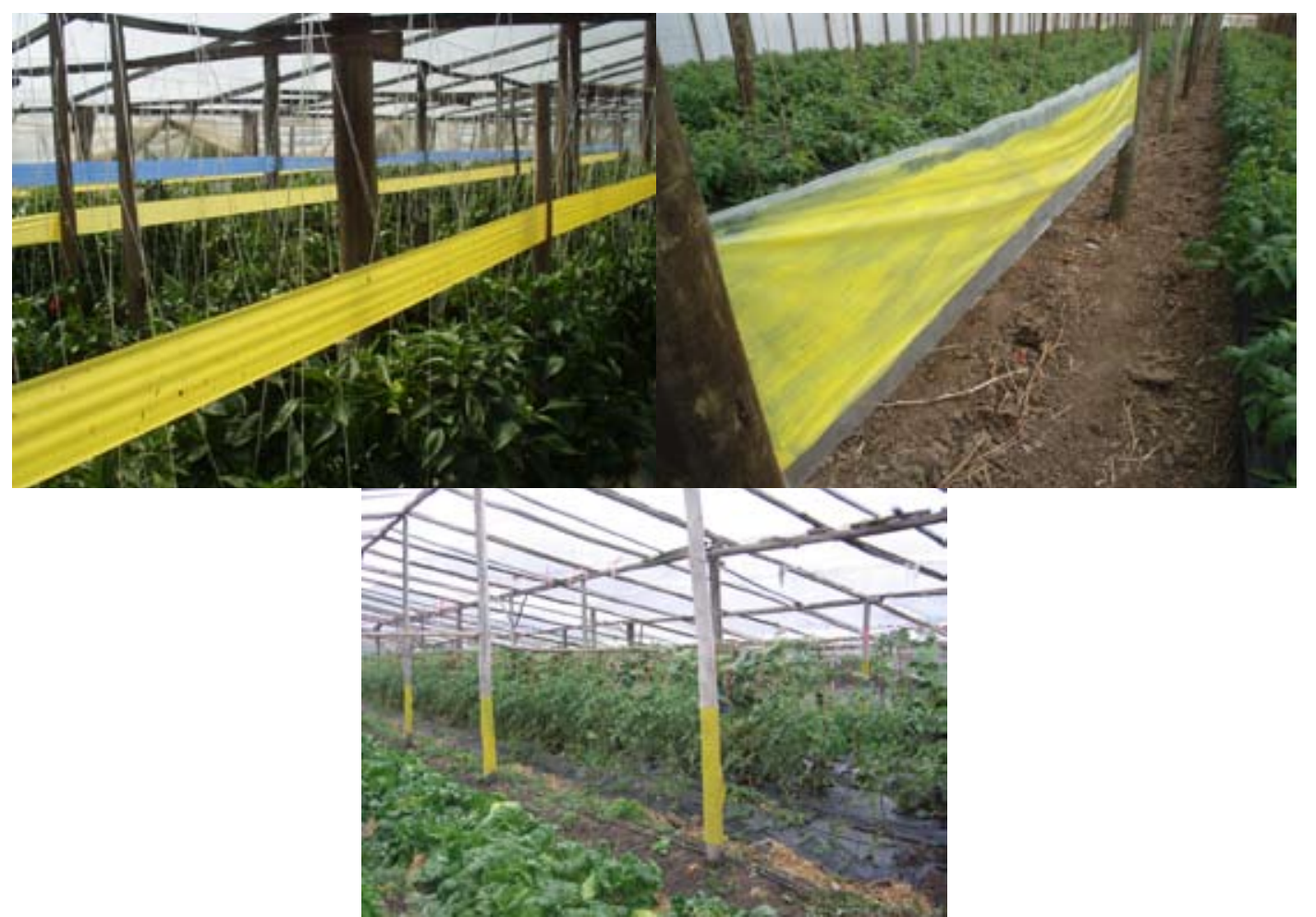

Figura 100. Diferentes formas de uso de superficies coloreadas pegajosas para captura masiva de vectores. Fotos D. Maeso. 
En la actualidad existen algunos productos comerciales formulados en base a atrayentes como feromonas (Thripline AMSTM de Syngenta Bioline, ThriPher de Biobest) o kairomonas derivadas de la planta huésped (Lurem-TR ${ }^{\mathrm{TM}}$, Koppert) que se utilizan para mejorar la captura y se incluyen en estrategias de control del insecto como "attract and kill", trampeo masivo o "push and pull" (Abdullah et al., 2015; Hamilton et al., 2005; Davison et al., 2007).

Los colores atractivos a su vez pueden funcionar como repelentes, si se modifican para que reflejen la luz UV (Vernon y Gillespie, 1990). Ese efecto explica el buen resultado de los mulchs reflectivos en repeler el arribo de las formas migrantes de pulgones y trips (Riley y Pappu, 2000; 2004; Stavisky et al., 2002; Momol et al., 2004; Reitz et al., 2003). Varios trabajos reportan menor incidencia de peste negra en cultivos de tomate con mulch plateado por la reducción de la actividad de trips debida a la modificación de la luminosidad a nivel de la planta (Greenough y Black, 1990; Csizinszky et al., 1995; Momol et al., 2004). También se menciona que el efecto se produce fundamentalmente en las primeras etapas del cultivo hasta que el mulch es cubierto por el follaje y que funciona mejor en morrón dado el hábito de la planta (Reitz et al., 2003).

Sin embargo, también se cita que los mulch reflectivos tienen efectos negativos para los enemigos naturales de trips y por lo que en cultivos donde hay multiplicación del vector o ciclos secundarios de trasmisión, como morrón, el beneficio se diluye o es perjudicial (Reitz et al., 2003).

El color de mulch afecta también en la temperatura en la zona radicular. Según Díaz-Pérez et al. (2007) esta fue más elevada en cultivos de tomate con mulch de color negro frente a los colores gris, plateado y blanco, lo cual estuvo asociado además con incidencia de peste negra más temprana y mayor. Según esos autores la mayor temperatura en la zona radicular observada con el mulch de color negro además aceleró la aparición de síntomas y la distribución sistémica de TSWV en la planta, lo cual se sumaría al efecto de la coloración sobre el vector.

Antignus et al. (1996) reportan la disminución de las poblaciones de mosca blanca (Bemisia tabaci), trips (F. occidentalis) y áfidos con la consiguiente menor incidencia de las virosis asociadas mediante el uso de plásticos que bloquean el $95 \%$ de la luz en el rango de $200-$ $380 \mathrm{~nm}$ del espectro (UV) y permiten el pasaje en el rango $380-700 \mathrm{~nm}$. El efecto se logra por alterar el reconocimiento del cultivo, los hábitos alimenticios y la actividad general de estos insectos. Antignus y Ben Yakir (2004) realizaron una completa revisión del tema en la cual sostienen que este tipo de plásticos no poseen efectos secundarios negativos sobre el cultivo, los polinizadores y los enemigos naturales.

En nuestro país Buenahora et al. (2003b) compararon dos invernáculos en la zona de Salto con y sin plástico bloqueante de UV y encontraron una disminución del número de trips capturados al utilizar plástico foto selectivo, destacando la disminución no solo en el período favorable para este vector sino también en los meses de invierno previniendo los ataques tempranos de primavera (cuadro 15). 
Cuadro 15.Evolución de la población de trips capturados en trampas cromáticas con pegante ltomado de Buenahora et al., 2003b).

\begin{tabular}{|c|c|c|c|c|}
\hline \multirow{2}{*}{ Fecha } & \multicolumn{2}{|c}{ Plástico foto selectivo } & \multicolumn{2}{c|}{ Plástico convencional } \\
\cline { 2 - 5 } & Trampa azul & Trampa amarilla & Trampa azul & Trampa amarilla \\
\hline $6 / 3 / 2002$ & $0,2^{1}$ & 3,3 & 10 & 22,2 \\
$13 / 3 / 2002$ & 2 & 9,3 & 11,2 & 40,1 \\
$20 / 3 / 2002$ & 3,4 & 9,7 & 7,3 & 58,9 \\
$27 / 3 / 2002$ & 5 & 17,7 & 6,7 & 26 \\
$3 / 4 / 2002$ & 1,1 & 2,4 & 3,8 & 14,4 \\
$10 / 4 / 2002$ & 2,7 & 3 & 5,1 & 12,6 \\
$17 / 4 / 2002$ & 0 & 0,3 & 6,5 & 1,1 \\
$24 / 4 / 2002$ & 0,3 & 0 & 3,2 & 0,2 \\
$2 / 5 / 2002$ & 0,4 & 0,9 & 15,3 & 1,6 \\
$8 / 5 / 2002$ & 0,9 & 0,4 & 3,8 & 4,2 \\
$15 / 5 / 2002$ & 0,6 & 1,1 & 3,2 & 5,3 \\
$22 / 5 / 2002$ & 0 & 0 & 6,1 & 0,9 \\
$29 / 5 / 2002$ & 0,3 & 0 & 2,3 & 4,1 \\
$5 / 6 / 2002$ & 0 & 0 & 1,7 & 0,1 \\
$12 / 6 / 2002$ & 0 & 0 & 1 & 0,2 \\
$19 / 6 / 2002$ & 0,3 & 0 & 0,8 & 0,2 \\
$26 / 6 / 2002$ & 0 & 0 & 1 & 0 \\
$3 / 7 / 2002$ & 0 & 0 & 1,1 & 0,8 \\
$10 / 7 / 2002$ & 0 & 0 & 0 & 0 \\
$17 / 7 / 2002$ & 0 & 0 & 0 & 0,2 \\
$22 / 7 / 2002$ & 0,1 & 0 & 5 & 1,1 \\
\hline
\end{tabular}

'Los datos representan la media de nueve trampas

\section{Erradicación de plantas enfermas}

El efecto de la erradicación de plantas enfermas dentro de un cultivo dependerá de la importancia de la infección secundaria en el desarrollo de la enfermedad y de la presencia de malezas y otros huéspedes en las cercanías que puedan servir de fuente de trips virulíferos (Adkins, 2000; Pappu et al., 2009). De todas formas, la eliminación de plantas enfermas minimiza los riesgos de trasmisión intra-cultivo y ha sido comprobado experimentalmente (Sánchez et al., 1999). La decisión final es de índole económica, en la que se deben realizar cálculos basados en la evolución de la enfermedad sobre la conveniencia de seguir destinando mano de obra para esta práctica, suspenderla o, finalmente levantar el cultivo. Esta tarea se dificulta en regiones donde se realizan cultivos de grandes extensiones, pero se están desarrollando sistemas automatizados robóticos que permitan la identificación de plantas enfermas en grandes extensiones de cultivos hortícolas y así facilitar la erradicación a gran escala (Schor et al., 2016). 
Es fundamental que la erradicación de plantas enfermas sea total, es costumbre solamente cortar la parte aérea, por lo que en pocos días la planta brota nuevamente exhibiendo síntomas (Figura 101).
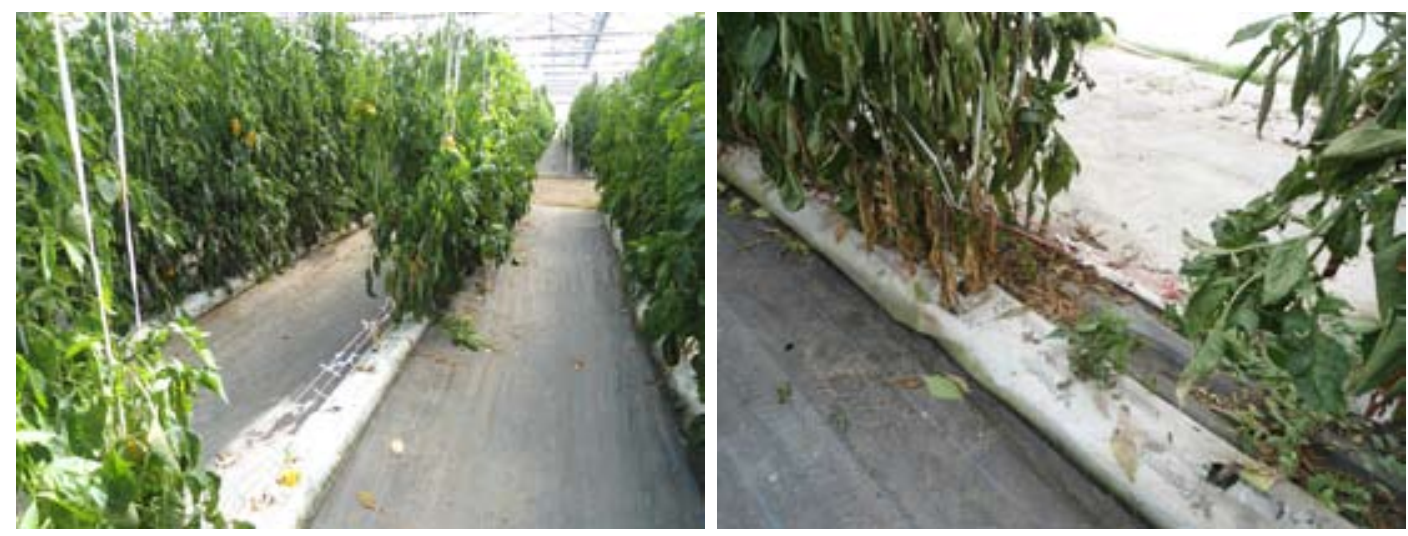

Figura 101. Erradicación de plantas afectadas como medida de control. Izquierda corte de la parte aérea, derecha brotación de planta erradicada presentando síntomas. Fotos D. Maeso

\section{Inductores de resistencia}

Las plantas poseen una cadena de respuestas para repeler, evitar o restringir a los patógenos en sus sitios de entrada, que es denominada resistencia sistémica y se describe como una forma de defensa. De acuerdo con el agente desencadenante ("elicitor") se separa en: 1) resistencia sistémica inducida (ISR) que es activada por rizobacterias y hongos promotores del crecimiento y 2) resistencia sistémica adquirida (SAR) activada por patógenos y compuestos químicos.

Algunos trabajos reportan los beneficios de la aplicación del inductor de resistencia Acibenzolar-S-methyl (ASM, Bion o Actigard) en tabaco (Pappu, 2000; Csinos et al. 2001; McPherson et al., 2005; Mandal et al., 2008; 240; Nischwitz et al., 2008; Cherry y Mila, 2011). Este producto limita la replicación y el movimiento del virus interfiriendo en la infección sistémica en tabaco. La activación de la resistencia comienza a los dos días de aplicado, llegando su máximo nivel a los cinco días (Mandal et al., 2008).

En ese cultivo la aplicación de ASM se recomienda junto con insecticidas y solo en situaciones de riesgo alto de la enfermedad, debido a su alto costo y por sus efectos negativos sobre el cultivo (Csinos et al., 2001; Walters y Heil, 2007; Nischwitz et al., 2008). Para definir esas situaciones se han desarrollado modelos de predicción de riesgo mediante las cuales se aplica solo insecticida, a dosis alta, baja, o se incluye al inductor de resistencia (Cherry y Mila, 2011).

Este producto también disminuyó la incidencia de peste negra en tomate aplicado junto a otras medidas de manejo como el mulch reflectivo e insecticidas (Momol et al., 2004; Reitz y Funderburk, 2015). Se destaca que su efecto individual es mayor si se trata de la única medida disponible frente a una fuerte presión de ataque (Momol et al., 2004). También existe información referente al uso de este producto en maní (Wells et al., 2002a). 
Beris et al. (2018) reportan buenos resultados contra esta enfermedad en tomate usando un producto comercial basado en la cepa MBI600 de la rizobacteria Bacillus amyloliquefaciens.

\section{Aplicación de aceites, insecticidas botánicos}

Si bien el uso de aceites ha sido estudiado y recomendado principalmente para virus trasmitidos en forma no persistente o semipersistente, algunos trabajos mencionan efectos beneficiosos de su aplicación para esta enfermedad. El efecto reportado es de prevención de la trasmisión de TSWV sin evitar los daños por la alimentación del insecto, lo cual indicaría que su efecto es sobre el patógeno (Allen et al., 1993).

También se menciona la reducción de la incidencia de peste negra en tomate por parte de ciertos insecticidas botánicos, aceites esenciales (Reitz et al., 2008) y otros derivados de Chenopodium sp. en condiciones de invernáculo (Chiasson et al., 2004) por la supresión de larvas utilizados en rotación con insecticidas (Funderburk, 2009). La ventaja de estos productos es su poco efecto negativo para enemigos naturales, pero en ocasiones, las altas concentraciones requeridas de estos aceites ocasionan reacciones fitotóxicas.

\section{Control químico}

El control de trips con insecticidas ha sido de las herramientas más utilizadas para controlar esta enfermedad en muchos cultivos, sin embargo, ha demostrado ser inefectivo ya que no previene la alimentación y por lo tanto la transmisión (Cullbreath et al.1991; Chamberlin et al., 1992; 1993; McPherson et al., 1992; 1999). Solamente se requieren cinco minutos para la trasmisión (Wijkamp, 1995) y la mayoría de los insecticidas necesitan más tiempo para eliminar al vector. Algunos autores sostienen que incluso algunos principios aumentan la trasmisión (específicamente imidacloprid) por parte de $F$. occidentalis porque estimulan la migración entre plantas y la realización de múltiples pruebas (Chaisuekul y Riley, 2001; Joost y Riley, 2005; 2008; Cullbreath et al., 2003; 2011; Herbert et al., 2007).

En algunos cultivos extensivos se aplican insecticidas sistémicos con gran persistencia en planta (p.ej. imidacloprid, carbofuran) a dosis altas en riegos a la base de la planta (Groves et al., 2001; Joost y Riley, 2005, Coutts y Jones, 2005; Chatzivassiliou, 2008). Dado que estos productos son de alta peligrosidad y poseen muchas otras contraindicaciones se desaconseja su uso y no cuentan con registro para ese uso en cultivos hortícolas en nuestro país.

Nault et al. (2003) mencionan la complementación de la aplicación de imidacloprid al trasplante con aplicaciones foliares de lambda-cialotrina, metamidofos y spinosad durante toda la estación. Se cita que imidacloprid reduce la trasmisión de TSWV en tomate, morrón y tabaco, actuando como repelente (Riley y Pappu, 2004; Pappu et al., 2000; Groves et al., 2001a). Coutts y Jones (2005) mencionan buenos resultados con la aplicación de tiametoxan o imidacloprid en riegos a trasplante o previamente en la prevención de peste negra en tomate y lechuga, destacando el mejor desempeño cuando las aplicaciones se hacían en el cultivo fuente de inóculo y el receptor a la vez. 
En el pasado el control de trips se basaba en frecuentes aplicaciones foliares de productos de amplio espectro como piretroides, organofosforados, carbamatos y neonicotinoides. En la actualidad esto es totalmente desaconsejable por efecto sobre enemigos naturales además de la toxicidad para trabajador y consumidor. A lo anterior debe agregarse la pérdida de efectividad por el desarrollo de resistencia en el insecto, por lo que la búsqueda de nuevos principios es permanente y cada vez más difícil debido a los requisitos que deben cumplir.

La resistencia de trips a insecticidas es un fenómeno de larga data y la han desarrollado rápidamente frente a muchos grupos. Una de las más notorias ha sido la resistencia a piretroides fruto de un mecanismo de detoxificación de estos insectos, muy ligado con su naturaleza polífaga. Sin embargo, también utilizan varios otros mecanismos para superar la toxicidad de diferentes clases de insecticidas (organofosforados, carbamatos). Los mecanismos pueden ser diferentes y/o compartidos según la clase y la población del insecto. La resistencia a menudo es duradera y no se revierte hasta varios años de no usar el grupo de insecticidas que la generó.

Uno de los grupos con mejor control son las espinosinas (spinosad y spinetoram), pertenecientes al grupo 5 del IRAC (Insecticide resistance action comitee) desarrolladas en los años 90 y que, aparentemente no tienen efectos negativos sobre algunos enemigos naturales como Orius spp. (Reitz et al., 2003). Lamentablemente ya se ha reportado resistencia a esta clase de insecticidas (Mouden et al., 2017).

Recientemente han surgido nuevos principios que se utilizan en otros países en el control de trips, compatibles con los agentes biológicos pero que aún no están registrados en Uruguay.

\section{Control biológico}

El control biológico de trips, tanto como plagas como vector, se ha desarrollado mucho en los últimos años, principalmente en cultivos protegidos, como consecuencia de la resistencia de este insecto a muchos de los principios activos y de los perjuicios para la salud y el ambiente derivados de la aplicación de insecticidas. Varios son los trabajos en el tema y los agentes y productos comerciales registrados en distintos países. En general es posible diferenciar dos estrategias, un control conservativo, o sea se trata de no alterar y beneficiar a los agentes nativos ya presentes en el agroecosistema y un control aumentativo o "inundativo" donde se liberan agentes biológicos producidos fuera del sistema.

En Uruguay varias instituciones y grupos están trabajando actualmente en el tema buscando soluciones integradas para este insecto y otras plagas de los cultivos protegidos.

De acuerdo con su naturaleza podemos separar a los controladores en dos tipos: macrobios que incluye a depredadores y parasitoides y microbios entre los que se encuentran los hongos entomopatógenos y los nematodos (Mouden et al., 2017). 
Entre los entomopatógenos se mencionan a los hongos Metarhizium spp. (Maniana et al., 2001), Verticillium lecanii (Zimmermann) Viegas (Heyler, 1993), y Beauveria bassiana (Bals.) Vuill. Sus conidios infectan trips penetrando la cutícula para obtener nutrientes para su crecimiento y reproducción. En general los adultos son los más sensibles que las larvas y pupas. Se reporta la reducción de la población de trips en invernaderos hortícolas y florales con aplicaciones foliares de estos hongos (Ugine et al, 2007). Existen algunas formulaciones comerciales para aplicación foliar a nivel mundial para uso en invernadero, pero los resultados son inconsistentes, dado que dependen mucho de las condiciones de temperatura y humedad, además de las dificultades que implica su producción masiva, almacenamiento y formulación (Mouden et al., 2017).

En nuestro país algunas instituciones y emprendimientos privados han evaluado cepas de estos controladores desarrolladas para otros problemas sanitarios en el control de plagas en invernáculos de hortícolas con resultados promisorios (INIA Proyecto FPTA 244).

Como norma general los mejores resultados se obtienen utilizando organismos autóctonos, lo cual facilita su registro oficial o cuando son introducidos desde regiones con condiciones similares lo cual facilita su adaptación.

La mayor parte de los trabajos en control biológico de trips con depredadores se han realizado usando dos depredadores inespecíficos: ácaros fitoseidos y antocóridos del género Orius (0. insidiosus, 0 . tristicolor, 0 . majusculus, 0 . insidiosus, 0 . albidipennis y 0 . laevigatus). Estos últimos se destacan dentro de los artrópodos benéficos, principalmente 0 . insidiosus (Say), un depredador generalista nativo del continente americano. 0 . insidiosus coloniza morrón, suprime efectivamente las poblaciones de trips, alimentándose fundamentalmente de larvas en flores y posee mayor capacidad de depredación y búsqueda que los fitoseidos (Funderburk et al., 2000; Ramachandran et al., 2001; Reitz et al., 2003; Baez et al., 2004). Por ello se lo considera un aliado clave para el manejo integrado en ese cultivo (Reitz y Funderburk, 2012).

0 . insidiosus y otras especies relacionadas son comercializadas a nivel mundial para realizar introducciones inundativas una vez que el cultivo de morrón está en floración. Este depredador no se instala permanentemente, pero el manejo de plaguicidas realizado para favorecerlo ayuda en la conservación de poblaciones de otros agentes nativos que controlan ésta y otras plagas (Reitz et al., 2003; Bosco et al., 2008). Orius spp. no pueden ser usados en tomate porque no tienen afinidad por hojas con muchos tricomas (Reitz et al., 2003). Otro inconveniente que presentan es que entran en diapausa en condiciones de día corto y su producción comercial no es fácil (Funderburk et al., 2000). Esta especie ha sido evaluada en nuestras condiciones e introducida en cultivos comerciales, pero no se ha podido lograr su establecimiento (Buenahora, 2014) y los estudios para conocer las razones y superarlas continúan.

Entre los ácaros fitoseidos se mencionan varias Amblyseius spp. (A. swiski, A. cucumerinus y A. barkeril como controladores de F. occidentalis y $T$. tabaci en cultivos de morrón y pepino bajo invernáculo. Amblyseius swirskii es muy utilizado en pimiento cuyas hembras matan larvas de F. occidentalis. A este ácaro tampoco le gustan las plantas con alta densidad de tricomas por lo que no se desempeña bien en tomate. 
Como los trips no son su alimento preferido es necesario suplementar su alimentación, sin embargo, su acción beneficiosa para el control de mosca blanca ha sido comprobada en nuestro país (Buenahora, 2014) implementándose su uso en invernáculos de morrón del norte desde hace varias temporadas. Este ácaro es fácil de criar y de producir masivamente y es comercializado mundialmente por varias empresas.

\section{Resistencia genética}

Como ocurre en numerosos cultivos, la resistencia genética es el método más efectivo para el control de esta enfermedad. Existen varios programas de mejoramiento a nivel mundial que están trabajando en la búsqueda e incorporación de genes de resistencia para esta enfermedad tanto al vector como al patógeno. Si bien los tamizados de los materiales en un comienzo se realizaron utilizando la inoculación mecánica (Mandal et al., 2008) esta metodología ha sido dejada de lado primero por las desventajas señaladas en cuanto a la pérdida de patogenicidad de las cepas mantenidas por este método y, fundamentalmente porque se ha demostrado que mediante el desafío utilizando trips infectivos muchos materiales mostraban, además de resistencia a la multiplicación del patógeno, interacción con el proceso de trasmisión por el insecto (Kumar et al., 1993; Roselló et al., 1997; Genda et al., 2008).

\section{Resistencia a trips}

Entre las estrategias más novedosas se encuentra la resistencia a trips mediante la liberación de acilazúcares lo cual contribuye a limitar la diseminación de TSWV en tomate y morrón como un efecto indirecto de la menor preferencia por el insecto para alimentación y oviposición (Maris et al., 2003; 2003b; Smeda et al., 2018; Ben-Mahmoud et al., 2019). Los acilazúcares son producidos y exudados por tricomas glandulares especializados de partes aéreas de las plantas de tomate y tienen efecto repelente para varias plagas incluidos los trips. Existe gran diversidad en su composición, propiedades y cantidad presente entre cultivares y especies silvestres emparentadas con el tomate. Se ha reportado que Solanum pennellii (Correll) D'Arcy, acceso LA716, particularmente posee abundantes tricomas glandulares tipo IV que exudan acilazúcar, por lo que muchos programas de mejoramiento están buscando la incorporación de los genes que gobiernan eses carácter en cultivares comerciales (Ben Mahmoud et al., 2019).

Existe información que sostiene que la resistencia a trips en morrón por acilazúcares depende de la madurez de la hoja y que a su vez el comportamiento es diferente entre líneas resistentes o susceptibles al insecto. En general, las hojas jóvenes son más susceptibles a la alimentación y oviposición de trips por ser las preferidas por su mayor contenido de nutrientes y agua. Sin embargo, en las líneas resistentes, la resistencia se expresa mejor en ellas debido a la mayor acumulación de compuestos de defensa, presentando menor alimentación y oviposición que en las líneas sensibles (van Haperen et al., 2019). Se reportan fuentes de resistencia a diferentes especies de trips en accesos pertenecientes a Capsicum annuum, $C$. baccatum, $C$. chinense y $C$. frutescens, sin embargo, aún no han sido incorporadas a cultivares comerciales (Maharijaya et al., 2011). 
Este tipo de resistencia al vector también se ha traducido en menor incidencia de Tomato spotted wilt orthotospovirus (Smeda et al., 2018)

Recientemente se han identificado otras fuentes de resistencia a trips en tomate que no dependen de los tricomas (Bac-Molenaar et al., 2019).

\section{Resistencia a orthotospovirus en tomate y morrón}

La resistencia incorporada actualmente a variedades comerciales de tomate y pimiento es genéticamente diferente, está basada en genes que no tienen ningún tipo de parentesco evolutivo entre sí y cuyo mecanismo de acción es diferente. Sin embargo, ambas desencadenan una respuesta hipersensible frente a la infección, consistente en la aparición de lesiones locales necróticas que confinan la infección en el punto de entrada e impiden la invasión sistémica a toda la planta. Por el momento solo se cuentan con pocos genes incorporados en cultivares comerciales ( $S w-5$ en tomate y Tsw en morrón) que sean efectivos contra un gran espectro de aislamientos de TSWV (Pappu et al., 2009) y cada vez es más frecuente el hallazgo de aislados que quiebran esta resistencia (Margaria et al., 2007; Lopez et al., 2011; Aramburu et al., 2007).

\section{a. Tomate}

A través de los años se han encontrado varias fuentes de resistencia dentro del género Lycopersicum (Stevens et al., 1994), habiéndose descrito siete genes: Swa1, Swb1, sw2, sw3, sw4, Sw-5, Sw-6 y Sw-7 (Soler et al., 2003). Salvo Sw-5, todos son específicos para algunos aislados y son fácilmente superados por otros aislados de TSWV u Orthotospovirus relacionados (Stevens et al., 1992; Boteas y Giordano, 1993; Roselló et al., 1998; 2003), de ahí que éste sea la fuente de resistencia más utilizada en cultivares de tomate.

Sw-5 fue incorporado a L. esculentum desde L. peruvianum (van Zijl et al., 1986) y confiere una resistencia amplia para aislados de TSWV de diferentes zonas geográficas (Stevens et al., 1992) y otros orthotospovirus que afectan tomate (Boiteux y Giordano, 1993; de Olivera et al., 2018). Se trata de un único locus localizado en la región subtelomérica del brazo largo del cromosoma 9 (Stevens et al., 1995; Brommonschenkel et al., 2000). Pertenece a la clase de genes de resistencia NBS-LRR al igual que los genes Mi (resistencia al nemátodo Melodoigyne incognita), 12 (a Fusarium oxysporum f. sp. lycopersicum raza 2), y Prf (uno de los genes involucrados en la resistencia a Pseudomonas syringae pv. tomatol de tomate (Brommonschenkel et al., 2000). Se han reportado que existen varios parálogos (origen común) de $S w-5$ denominados $S w-5 a$ a $S w-5 e$, siendo el $S w-5 b$ el utilizado en los cultivares comerciales. 


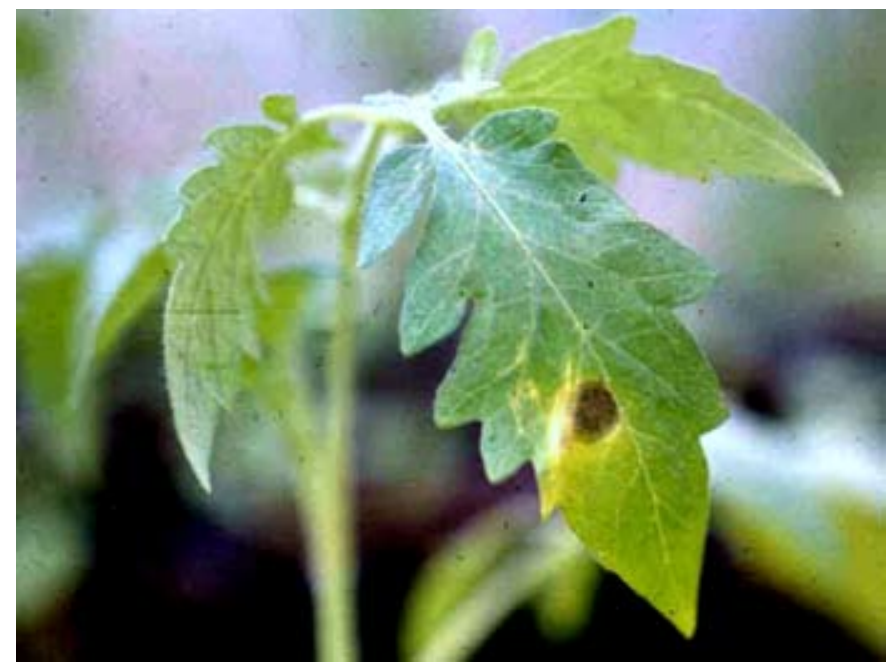

Figura 102. Lesión local necrótica desarrollada por un cultivar con el gen Sw-5 luego de la inoculación mecánica con TSWV. Foto D. Maeso

En las plantas de tomate que portan el gen $S_{w}-5$ el virus no se disemina sistémicamente y si bien en muchos casos las hojas inoculadas mecánicamente no exhiben síntomas, lo común es que aparezcan lesiones locales necróticas (Figura 102) evidenciando una respuesta de hipersensibilidad (Roselló et al. 1998; Stevens et al. 1992; Peiró et al., 2014). Se ha demostrado que la resistencia mediada por $S_{w}-5$ se desencadena por la proteína de movimiento célula a célula NS de TSWV (Hallwass et al., 2014). A nivel molecular se ha encontrado que el genoma de TSWV es procesado de forma diferente respecto a los tres ARNs que lo componen (Large, L, Medium, M y Small S) en las plantas Sw-5(+) comparadas con las Sw-5(-). En las primeras el $A R N L$ es el que tiene el mayor número de $A R N s$ virales pequeños de interferencia (vsiRNAs), mientras que en las $S w-5(-)$ el mayor número pertenecía al ARN S lo cual está relacionado con las respuestas de la planta frente al virus (Olaya et al., 2020).

Es un gen dominante que posee lo que se llama "penetración incompleta" que determina que en un pequeño porcentaje de plantas (menor al $2 \%$ ) no se exprese correctamente y puedan ser infectadas sistémicamente (Aramburu et al., 2007). La resistencia es eficaz en toda la planta salvo en el fruto (de Haan et al., 1996), donde la infección por la alimentación directa de trips infectivos desde floración ocasiona lesiones locales con anillos concéntricos producto de reacciones de hipersensibilidad (Aramburu y Rodríguez, 1999; Moriones et al., 1998; Aramburu et al., 2000; Houle y Kennedy, 2017) (Figura 103). Houle y Kennedy (2017) demostraron que la alimentación de trips infectivos en flores de cultivares resistentes de tomate produjeron síntomas no solo en frutos sino también en hojas cercanas al racimo. Hasta el momento estos problemas en la eficacia del gen tienen muy poco impacto económico. 

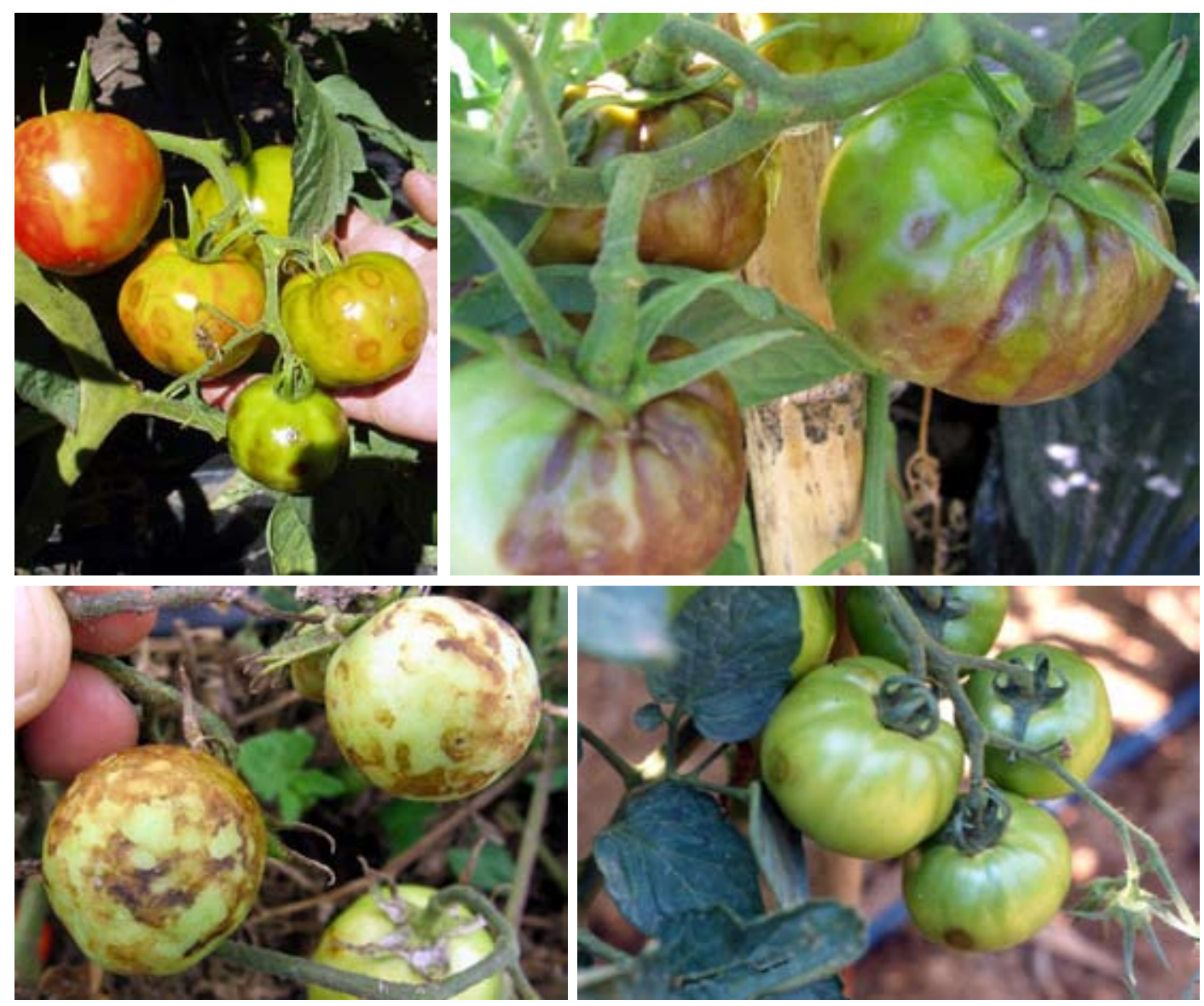

Figura 103. Síntomas de peste negra en frutos de cultivares con el gen Sw-5. Fotos D. Maeso

La búsqueda de genes de resistencia, pensando en el supuesto caso de que $S w-5$ deba ser suplantado, continúa. Se están explorando fuentes en accesos de S. peruvianum 'UPV 1' $(S w-6)$ y en S. chilense 'LA 1938' (Sw-7) y han sido introgresados en tomates cultivados (Roselló et al., 1998; 2001; Canady et al., 2001; Stevens et al., 2007; Dianese et al., 2011). Sw-6 protege contra un rango acotado de aislados y confiere solo resistencia parcial a la inoculación con trips (Roselló et al., 1998). La resistencia derivada de S. chilense ha demostrado ser eficiente frente a aislados que sobrepasan a $S w$ - 5 y es conferida por un solo gen dominante no ligado a $S w-5$ ubicado en el cromosoma 12 y que se denominó Sw-7 (Stevens, 2009). De acuerdo con Padmanabhan et al. (2019) la resistencia conferida por Sw-7 está relacionada con la inducción de acumulación de callosa, deposición de lignina, ciertos procesos de proteólisis, la activación/represión de la transcripción, la fosforilación y la proteína PR-5 la cual enlentece la acumulación de virus y la expresión de síntomas. 
Es importante destacar una fuente de resistencia a campo o tolerancia mencionada desde hace mucho tiempo como lo es la de los cultivares del tipo "platense", "araña" o "cartón" (Figura 104). Este grupo de variedades originarias como lo dice su nombre de nuestra región fueron muy cultivadas en Uruguay como tardíos. Se plantaban a campo en la zona de Rincón del Cerro (Montevideo) y sus frutos eran madurados en galpón, y si bien eran atacados con peste negra su severidad era menor que en otras variedades. Su tolerancia, hizo que se utilizaran en programas de mejoramiento previo al hallazgo de genes de especies silvestres. Una de ellas "Rey de los Tempranos" es mencionada en muchos trabajos sobre esta enfermedad y se estima que su resistencia es controlada por al menos 1 a 3 genes con interacción semi-alélica dominante (Juliatti y Maluf 1995). El cultivo de este tipo de tomate fue discontinuado debido a la apariencia externa de sus frutos (con cascos, aplanados, muy gran tamaño, lóculos asimétricos y hombros marcados de color verde), sin embargo, actualmente es plantado por algunos productores orgánicos que revalorizan su rusticidad y sabor.

Loica, un cultivar de industria muy difundido en nuestro país en los años 80 por la Estación Experimental Las Brujas, desarrollado por INTA, Argentina, heredó la resistencia de sus ancestros platenses y como estos si bien se infecta, los ataques son menos severos que otras variedades (Figura 105).
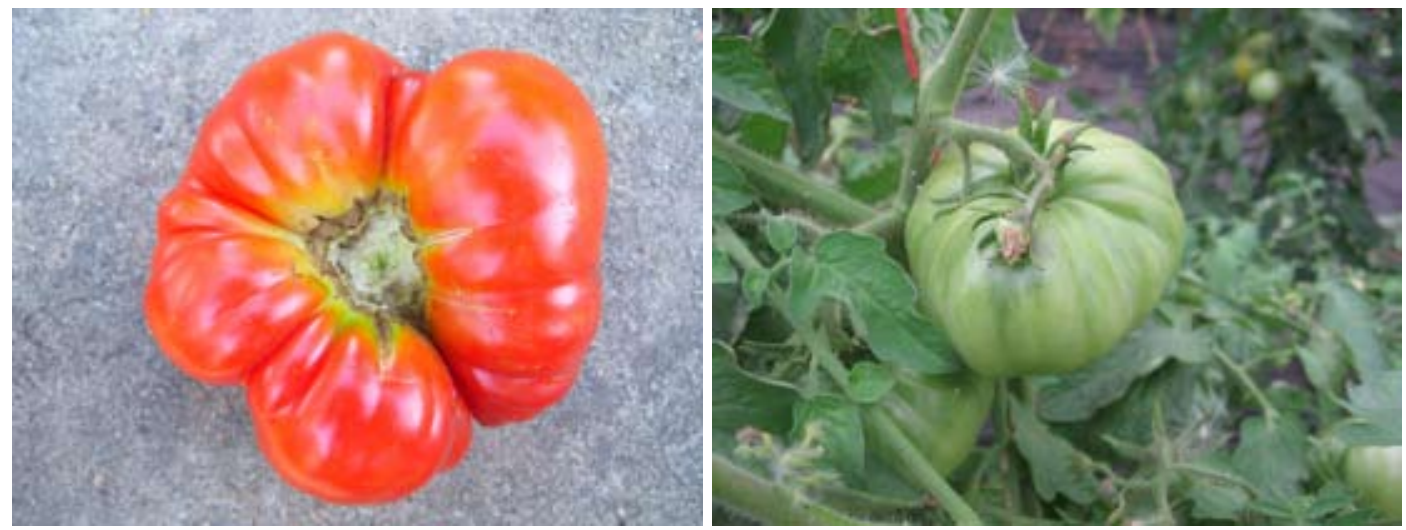

Figura 104. Frutos de tomate tipo Platense. Fotos D. Maeso
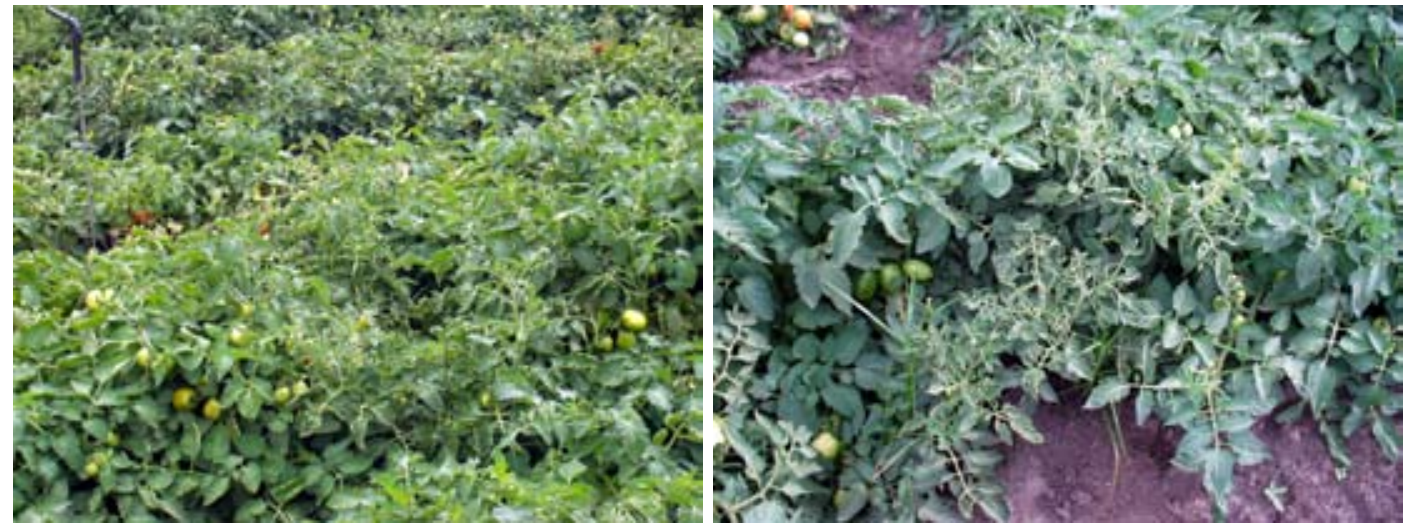

Figura 105. Cultivo de tomate Loica atacado con peste negra. Nótese la falta de necrosis y la producción de frutos. Fotos D. Maeso 


\section{b. Morrón}

La resistencia a peste negra disponible comercialmente hasta el momento en morrón (Capsicum annuum L.) está mediada por un único gen dominante Tsw (Boiteaux, 1995), de Capsicum chinensis Jacquin originario de la Amazonia presente en las accesiones de C. chinensis 'PI152225' y 'PI159236' (Black et al., 1991; 1996; Boiteaux et al., 1993; Boiteux y de Ávila, 1994, Moury et al.1997). Se encuentra localizado en el cromosoma 10 vecino a dos genes $R$ dominantes para potyvirus, $P v r 4$ and $P v r 7$ y no guarda ninguna relación evolutiva ni genética con Sw-5 (Jahn et al., 2000).

Este gen, al reconocer al factor de avirulencia de TSWV provoca una reacción de hipersensibilidad, (HR) que ocasiona la muerte de las células que rodean el punto de infección, seguido de la absición de la hoja inoculada, limitando así el movimiento del virus, lo cual ha sido verificado mediante análisis (Soler et al., 1999). En la Figura 106 se muestran algunos síntomas atribuibles a la reacción de hipersensibilidad de cultivares de morrón con el gen TsW.

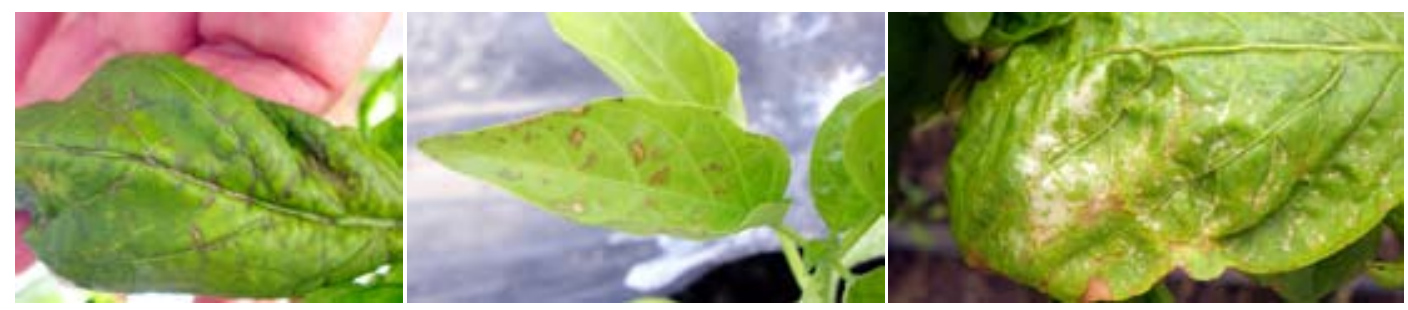

Figura 106. Síntomas atribuibles a la reacción de hipersensibilidad en cultivares de morrón con el gen Tsw.

Se ha discutido la identidad de ese factor de avirulencia en si se trata del gen de la proteína NSs (Magaria et al., 2007; De Ronde et al., 2013) o del de la proteína N (Lovato et al., 2008), pero se reconoce que es específico y solo funciona en la relación TSWV-TSW. Por lo tanto esta resistencia no funciona con otros virus capaces de producir la enfermedad como lo son GRSV, TCSV e INSV (Boiteaux y de Ávila, 1994). Además, se ha comprobado que se inactiva en plantas jóvenes cuando la temperatura es alta por varios días (28-32 ${ }^{\circ} \mathrm{C}$ ), lo cual rara vez ocurre en plantas adultas (Roggero et al., 1996; Moury et al., 1998; Soler et al., 1998; Chung et al., 2018). Por esa razón los esfuerzos en mejoramiento se han centrado en líneas que exhibieran resistencia en etapas juveniles aún a altas temperaturas (Soler et al., 1998).

Otro punto importante para asegurar un buen desempeño de esta fuente de resistencia en híbridos comerciales es que el gen Tsw esté presente como homocigota (Moury et al., 1998).

Al igual que $S w-5$ también es un gen dominante con penetración incompleta, cuya eficacia, es alterada por varios factores como la cantidad de inóculo a la que están sometidas las plantas, el estado fenológico de éstas y, de manera muy determinante por el aumento de la temperatura (Aramburu et al., 2007). 
En la zona sur de Uruguay es común que cultivares comercializados como resistentes y que según el distribuidor portan el gen Tsw se comporten como susceptibles y evidencien grandes pérdidas por la enfermedad. Este fenómeno lo comprobamos en el trabajo experimental anteriormente descrito en el que se evaluaron varios cultivares de uso frecuente a cuyos cultivos recibían protección con mallas anti-insectos. En la Figura 107 se observa la evolución de la presencia de síntomas para diferentes cultivares. Solamente se registró un ataque severo de la enfermedad en la temporada 2011-2012 y en los dos cultivares resistentes por igual. Aparentemente a comienzos de enero 2012 se comenzaron a manifestar síntomas derivados de infecciones secundarias, las cuales no ocurrieron en las otras dos temporadas en las que se podría suponer que solamente desarrollaron síntomas las plantas infectadas del ciclo primario.

En la Figura 108 se presentan datos de temperatura promedio diaria registrada en el interior de los invernáculos durante el comienzo de la enfermedad y como vemos no existen grandes diferencias entre las temporadas o temperaturas muy altas que puedan explicar el mal desempeño de los cultivares resistentes. En el cuadro 16 se presentan algunos datos relevantes de las tres temporadas. Como vemos, la fecha de aparición de los primeros síntomas fue diferente y, mientras en la temporada 2011-2012 hubo un gran incremento en plantas enfermas a los 20 días aproximadamente en las otras dos prácticamente la enfermedad no se registraron ciclos secundarios. Evidentemente la resistencia conferida por el gen Tsw fue sobrepasada por el patógeno durante la temporada 2011-2012, lo cual no puede ser explicado por la ocurrencia de altas temperaturas por lo que queda pendiente estudiar si en nuestra zona están circulando variantes que la quiebran como ocurre en regiones hortícolas de países vecinos (Dal Bó, 2011). La explicación de las diferencias entre temporadas seguramente sea por factores que hayan promovido la transmisión secundaria dentro del cultivo en 2011-2012, recordemos que en ese estudio se encontraron varias malezas con síntomas infectadas con TSWV.
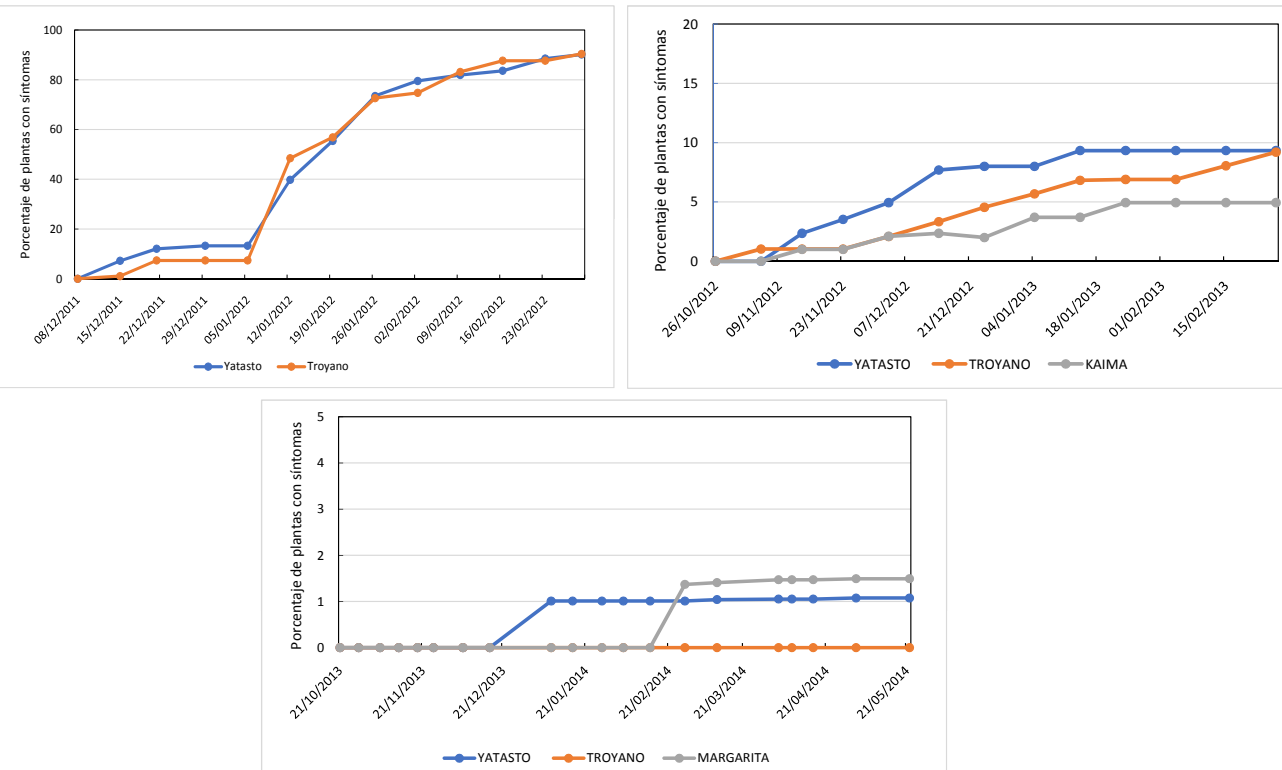

Figura 107. Evolución del porcentaje de plantas son síntomas de peste negra en invernáculos de morrón en Canelón Chico (Departamento de Canelones) en diferentes cultivares con resistencia a peste negra durante las temporadas 2011-2014. 


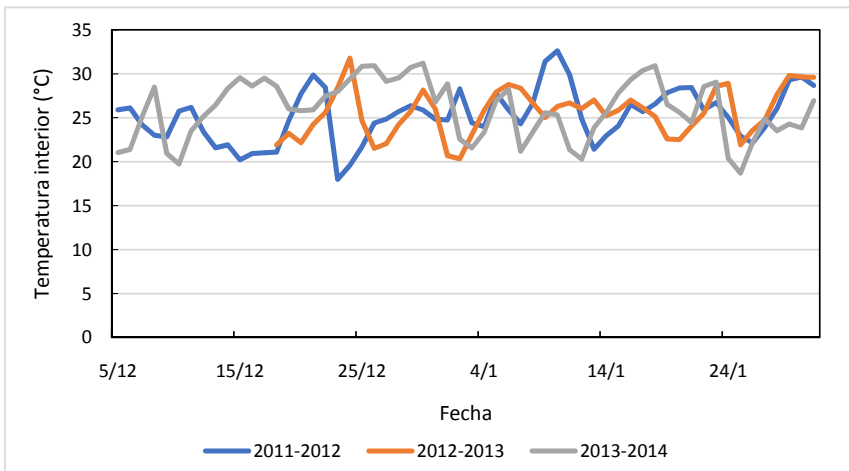

Figura 108. Temperatura promedio diaria en el período diciembre-enero al interior de los invernáculos estudiados en las tres temporadas.

Cuadro 16.Información relevante de la evolución de síntomas de peste negra en cultivos de morrón en invernadero estudiados en el período 2011-2014.

\begin{tabular}{|l|c|c|c|}
\hline & \multicolumn{3}{|c|}{ Temporada de cultivo } \\
\hline & $2011-12$ & $2012-13$ & $2013-14$ \\
\hline Primeros síntomas $^{1}$ & 8-Dic & 5-Nov & 8-Ene \\
\hline Incremento de síntomas $^{2}$ & 29-Dic & 14-Dic & 27-Feb \\
\hline Fin de cultivo $^{3}$ & 9-Feb & 8-May & 22-May \\
\hline Porcentaje final de plantas con síntoma $^{3}$ & 75 & 8 & 1 \\
\hline
\end{tabular}

${ }^{1}$ Fecha de aparición de las primeras plantas con síntomas

${ }^{2}$ Fecha en la que se produjo un aumento importante en el número de plantas con síntomas

${ }^{3} \mathrm{Fech}$ en la que se abandonó el cultivo

${ }^{4}$ Porcentaje de plantas enfermas al final del cultivo, promedio de invernáculos con y sin malla perimetral

La búsqueda de nuevas fuentes de resistencia en pimiento que sustituyan a Tsw continúa y se ha identificado recursos promisorios derivados de Capsicum baccatum (Soler et al., 2015).

Se ha reportado que las plantas de pimiento aún sin genes de resistencia presentan menor incidencia y perjuicios por peste negra debido al conocido efecto de resistencia de planta adulta (Beaudoin et al., 2009).

\section{Quiebre de resistencia a orthotospovirus}

Desde la aparición en el mercado de los cultivares con resistencia a peste negra se han detectado síntomas en cultivos plantados con híbridos resistentes, lo cual ha llevado a incansables discusiones acerca de que si son fruto de lo explicado anteriormente (penetración incompleta, falta de resistencia en fruto, condiciones ambientales que la alteran, estado fenológico sensible), que esos genes no estén presentes o se encuentren en forma heterocigota 0 , que la resistencia ha sido superada con la aparición de nuevas variantes del virus. Uno de los primeros pasos para dilucidar el problema es realizar inoculaciones con los nuevos aislados y los frecuentes en la región para verificar el desarrollo de la reacción de hipersensibilidad o la aparición de síntomas sistémicos de forma de conocer si el gen está 
presente. En 1999, cuando comenzaron a aparecer síntomas en cultivares de tomate resistentes en nuestro país, se realizaron inoculaciones mecánicas de plantines en dos estados fenológicos (de $20 \mathrm{~cm}$. de altura y 3 hojas, y de $50 \mathrm{~cm}$. y 6-7 hojas) en INIA Las Brujas que verificaron el desarrollo de lesiones locales de hipersensibilidad en algunos de los cultivares comerciales portadores del gen $S w-5$ más utilizados en ese momento y el desarrollo de síntomas en aquellos sin el gen (cuadro 17, Figura 109, Maeso et al., 2005).
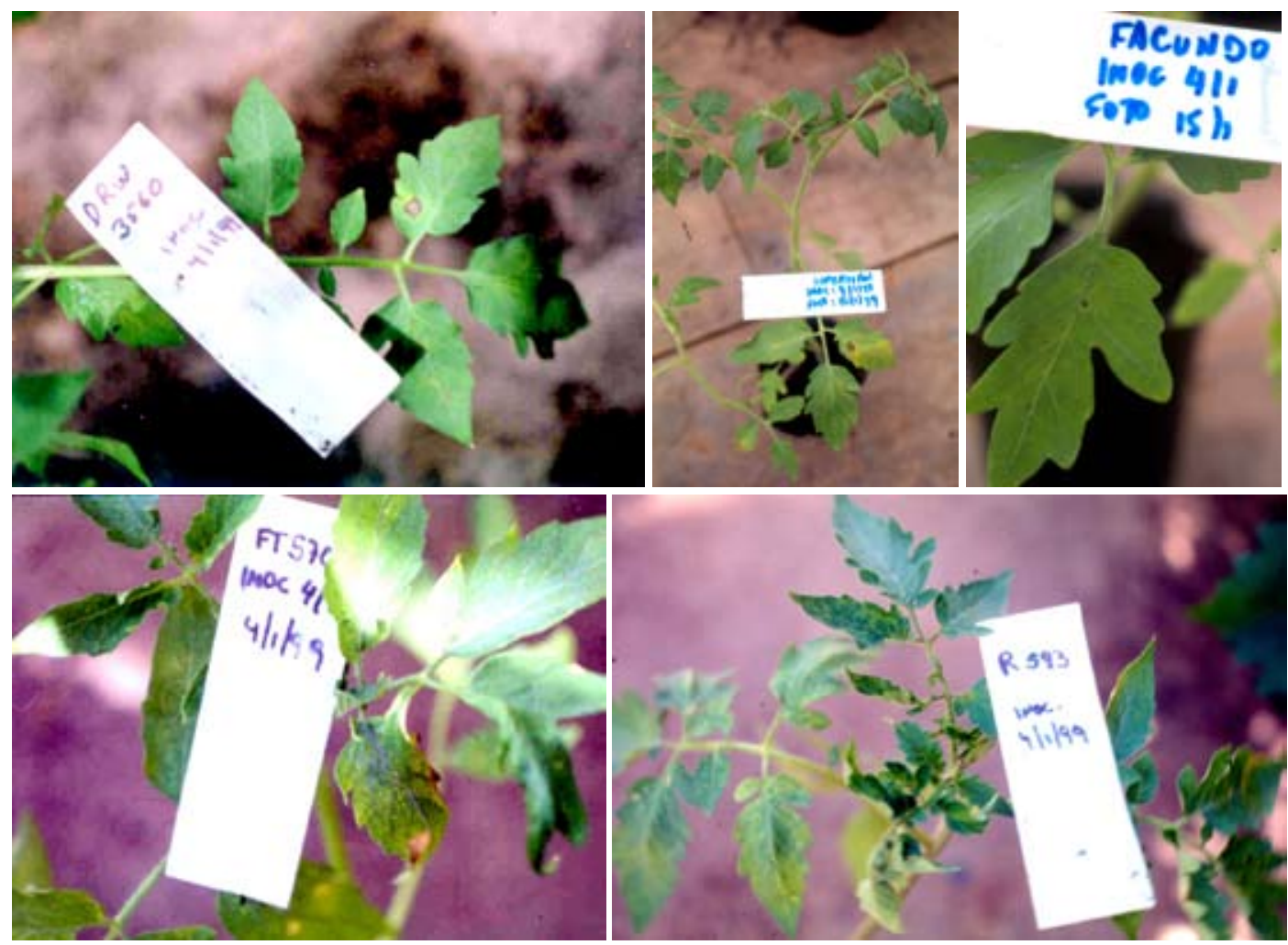

Figura 109. Reacciones a la inoculación mecánica de algunos cultivares de tomate en experimentos 1999. Arriba: reacciones de hipersensibilidad típica del gen Sw-5 exhibida por las variedades resistentes y abajo: síntomas sistémicos en cultivares sensibles. Fotos: D. Maeso 
Cuadro 17. Resultados de inoculaciones de cultivares comerciales con orthotospovirus

\begin{tabular}{|c|c|c|c|c|c|c|}
\hline \multirow{3}{*}{ Cultivar } & \multirow{2}{*}{\multicolumn{3}{|c|}{$\begin{array}{c}\text { Primer experimento (plantas } 20 \mathrm{~cm} \\
\text { y tres hojas) } \\
\% \text { de plantas/tipo de síntoma }\end{array}$}} & \multirow{2}{*}{\multicolumn{3}{|c|}{$\begin{array}{l}\text { Segundo experimento (plantas } 50 \\
\text { cm y 6-7 hojas) } \\
\% \text { de plantas/tipo de síntoma }\end{array}$}} \\
\hline & & & & & & \\
\hline & $\begin{array}{l}\text { "Peste } \\
\text { Negra"1 }\end{array}$ & $\mathrm{HR}^{2}$ & $\begin{array}{c}\text { Sin sínto- } \\
\mathrm{mas}^{3}\end{array}$ & $\begin{array}{l}\text { "Peste } \\
\text { Negra" }\end{array}$ & $\mathrm{HR}$ & $\begin{array}{c}\text { Sin } \\
\text { síntomas }\end{array}$ \\
\hline FT 5702 & $78 \%$ & 0 & $22 \%$ & $28 \%$ & $0 \%$ & $72 \%$ \\
\hline R 593 & $88 \%$ & 0 & $12 \%$ & $44 \%$ & $0 \%$ & $56 \%$ \\
\hline FA 554 & $58 \%$ & 0 & $42 \%$ & $80 \%$ & $0 \%$ & $20 \%$ \\
\hline DRW 3560 & $0 \%$ & $95 \%$ & $5 \%$ & $0 \%$ & $88 \%$ & $12 \%$ \\
\hline Facundo & $0 \%$ & $100 \%$ & $0 \%$ & $0 \%$ & $69 \%$ & $31 \%$ \\
\hline Superman & $0 \%$ & $85 \%$ & $15 \%$ & $0 \%$ & $81 \%$ & $19 \%$ \\
\hline E 30369 & $0 \%$ & $55 \%$ & $45 \%$ & $0 \%$ & $40 \%$ & $60 \%$ \\
\hline
\end{tabular}

${ }^{1}$ Incluye: anillos cloróticos, nervaduras violáceas, necrosis de ápice.

${ }^{2}$ HR: Reacción de hipersensibilidad. Lesión necrótica con círculos concéntricos.

${ }^{3}$ No se observaron síntomas. Probablemente debido a fallas en la inoculación.

Para complementar estos estudios actualmente se cuentan con marcadores moleculares para los genes Sw-5 (Gardland et al., 2005; Rodrigues do Nacimento et al., 2009; Dianese et al., 2010; Panthee, 2012; Arruabarrena et al., 2015; Giambiasi et al., 2019) y Sw-7 (Stevens, 2009) de tomate, pero aún no el gen Tsw de morrón. También se cuenta con técnicas moleculares para identificar las cepas que sobrepasan al gen Sw-5 (di Rienzo et al., 2018).

Si se comprueba la presencia del gen de resistencia, la infección con orthotospovirus y se observan síntomas sistémicos en un gran número de plantas, probablemente nos encontremos frente a variantes capaces de sobrepasar la resistencia. Con el trascurso de los años se ha denunciado la existencia de esas variantes en tomate (Cho et al., 1996; Thompson y van Zijl, 1996; Latham y Jones, 1998; Aramburu y Martí, 2003, Ciuffo et al., 2005; Gordillo et al., 2008) y en morrón (Magaria et al., 2004; Roggero et al., 1999; 2000; 2002; Finetti Sialer, et al., 2002; Thomas-Carroll y Jones, 2003; Ciuffo et al., 2005; Persley et al., 2006; Sharman y Persley, 2006; Batuman et al., 2017) en diferentes áreas del planeta.

Como ya se ha comentado, la base genética de resistencia de los genes Sw-5 y Tsw es diferente, por lo que es lógico pensar que la genética de las variantes capaces de sobrepasarlas también lo sea. Es está en consonancia con el hecho de que las variantes de TSWV que rompen la resistencia del gen $S w-5$ en tomate, como norma general, no son capaces de sobrepasar la resistencia del gen Tsw en pimiento y viceversa (Aramburu et al., 2007; Debreczeni et al., 2015).

Se ha demostrado que los determinantes responsables del quiebre de la resistencia del gen Sw-5 se localizan en el segmento M (medio; Hoffmann et al., 2001), mientras que los del gen Tsw en el segmento S (pequeño) del ARN viral (Jahn et al., 2000). 
Los aislados que quiebran al gen $S w-5$ poseen dos eventos de sustitución de un único nucleótido en el gen que codifica la proteína de movimiento $\mathrm{NS}_{\mathrm{m}}$ (C118Y y T120N) que se traducen en un gran cambio en la patogenicidad (Lopez et al., 2011; Peiró et al., 2014). Algunos autores sostienen que las variantes que rompen la resistencia del gen Tsw muestran cambios en el gen que codifica la proteína NSs. Esto no ha sido comprobado en algunas de ellas, lo cual podría deberse a diferencias en orígenes y estrategias de estas variantes (Aramburu et al., 2007; Margaria et al., 2007).

La difusión y distribución de las variantes de TSWV que sobrepasan la resistencia en pimiento es más amplia que las de tomate, lo cual puede estar relacionado con un número mayor de cepas diferentes y más competitivas. Algunas infectan sistémicamente a las plantas con el gen Tsw, induciendo los típicos síntomas de peste negra sin ninguna reacción de hipersensibilidad previa. Otras, producen la respuesta hipersensible atípica, que da lugar a grandes anillos y líneas necróticas en las hojas inoculadas a medida que progresa la infección sistémica, indicando que la respuesta no fue lo suficientemente eficaz y fue sobrepasada. Incluso se ha reportado un incremento de la intensidad de los síntomas en plantas infectadas con mezclas de cepas con y sin capacidad de quebrar la resistencia (Aramburu et al., 2007; 2015).

Estudios en condiciones controladas indican que las cepas que quiebran a la resistencia de Sw-5 y Tsw son competitivas y estables (Thomas-Carroll y Jones, 2003; Aramburu et al., 2010). Deberczeni et al. (2014) reportan que la capacidad de trasmisión por el vector es similar en las cepas que quiebran resistencia en morrón y en tomate, y que ésta depende más de la concentración de virus que se alcanza dentro del vector que de la existente en la planta.

Según Dal Bo (2011), a partir de 2006 se comenzaron a observar en la zona hortícola de La Plata plantas de cultivares resistentes de morrón con síntomas de peste negra e infección con TSWV (98\%) comprobada lo cual hizo suponer la existencia de variantes de TSWV que quiebran la resistencia conferida por el gen Tsw (Calvo et al., 2008) y advierte de los riesgos de usar cultivares con un solo gen de resistencia.

En nuestro país por el momento no se ha verificado la presencia de aislados que superen la resistencia en ninguno de los dos cultivos, sin embargo, son numerosos los testimonios de productores que han sufrido pérdidas por esta enfermedad aun plantando las variedades comerciales con resistencia.

Varios programas de mejoramiento se encuentran trabajando para evaluar fuentes de resistencia eficaz frente a estas cepas. Para tomate se han detectado entradas promisorias en las especies S. habrochaites y S. peruvianum. En el caso del pimiento el proceso no está tan avanzado se maneja un gran número de entradas de distintas especies relacionadas con el pimiento cultivado (Capsicum annuum, C. baccatum, C. chacoense, C. chinense, C. frutescens y C. pubescens), (Aramburu et al., 2007). 
Con los avances de la ciencia en el campo de la biología molecular se ha podido conocer el funcionamiento de la interacción planta-virus y los procesos que pueden ser interferidos para desfavorecer al patógeno. Existen numerosos trabajos de investigación que aportan información sobre estrategias tendientes a contribuir en el manejo de esta enfermedad. Por el momento se encuentran en una etapa experimental tratando de conocer mejor los mecanismos y las interacciones que los gobiernan y su puesta en práctica en condiciones comerciales dependerá no solo de los avances sino también de múltiples otros factores que condicionan su implementación.

Mucho se ha avanzado en el campo de ingenieria genética, entre ellos en la resistencia derivada del patógeno a través de la transformación del huésped con el gen $\mathrm{N}$ de la cubierta proteica (Nervo et al., 2003) la cual ha sido evaluada en condiciones de campo (Herrero et al., 2000; Magbanua et al., 2000; Yang et al., 2004). Sin embargo, a nivel experimental ya se han encontrado aislados que superan la resistencia de las plantas transformadas (Hoffmann et al., 2001). Al igual que los genes descritos en el apartado anterior, desde el punto de vista práctico, por tratarse de un solo gen está fácilmente sujeto a cambios en el virus.

También se han realizado estudios en el silenciamiento génico del ARN del virus a través de pequeños ARN de interferencia (Mitter et al., 2016; Ramesh et al., 2017; Carbonell et al., 2019) y otras estrategias utilizando "aislados defectuosos interferentes" (defective interfering viruses, DIs) que compiten con el genoma parental para su reproducción.

\section{Producción agroecológica y enfermedades a virus en tomate}

Recientemente se está difundiendo la producción agroecológica de cultivos hortícolas en invernáculo como alternativa a la convencional y son muchos los testimonios sobre mejoras en el manejo de enfermedades y plagas. Si bien existen pocos trabajos científicos publicados, Lázaro et al. (2019) reportan en la zona este de España (Provincias de Valencia y Alicante) menor incidencia de virosis, entre ellas TSWV, en cultivos de tomate agroecológicos. Fundamentan sus resultados en que bajo ese sistema existe una mayor diversidad de plantas que cambiaría la tradicional flora espontánea que acompaña al cultivo, el aumento de controladores biológicos del vector y el desarrollo del fenómeno de resistencia sistémica adquirida por el cambio de la microflora asociada al cultivo.

Dada la escasa información y lo reciente de la expansión a mayor escala de esta forma de producción en nuestro país, es necesario contar con trabajos que avalen estos beneficios tanto para esta como otras enfermedades y plagas del cultivo. 


\section{ÍNDICES DE RIESGO}

El estudio de la enfermedad y los factores epidemiológicos relacionados ha permitido el desarrollo de índices de riesgo que predicen la probable magnitud de los ataques y guían en la aplicación de medidas preventivas en varios cultivos.

Fundamentalmente han sido diseñados para cultivos extensivos en los que se debe decidir el uso o no de determinada medida. Tal es el caso de maní en Georgia, (Culbreath et al., 1999; 2003; 2008, Olatinwo et al., 2008; 2009; Srinivasan et al., 2017) en los que se asignan valores numéricos a determinadas prácticas de producción basadas en su relativa importancia sobre la enfermedad.

Culbreath et al. (1999) desarrollaron un "índice de evaluación de riesgo" de TSWV en maní para el sur de los EE. UU. que considera la historia del predio, cultivar, fecha de plantación, densidad de siembra, orientación de las filas, prácticas de laboreo y aplicación de insecticidas, a los que les asigna diferentes puntajes. Posteriormente se incluyeron en este índice algunas variables climáticas que inciden sobre la trasmisión de la enfermedad como la temperatura media diaria, mínima, lluvia acumulada, número de días de lluvia, evapotranspiración en los meses de primavera y número de días entre determinada fecha y la plantación, para los cuales determinaron valores límites (Olatinwo et al., 2008; 2009).

Cherry y Mila (2011) proponen un índice de riesgo para la enfermedad en tabaco basado en el cálculo de grados días acumulados por encima de $10,5^{\circ} \mathrm{C}$ contados desde el $1^{\circ}$ enero hasta 10 mayo (hemisferio norte) el cual se complementa con la historia previa del predio con esta enfermedad. Las predicciones de riesgo para tabaco en Carolina del Norte se encuentran disponibles en http://climate.ncsu.edu/thrips en la cual los usuarios deben ingresar la historia media de incidencia de TSWV en su predio y la fecha de siembra.

Mateus et al. (2012) crearon un índice de riesgo de TSWV para cultivos de tomate para industria en Portugal. Entre los factores que consideran está la presencia de síntomas en tomate y malezas en el cultivo, la captura de vectores en trampas pegajosas, los ataques en el predio en las dos últimas temporadas y la ocurrencia de síntomas en cultivos cercanos. A estos parámetros les asignaron valores creando un índice de riesgo con un máximo de 14 puntos adjudicando la mayor ponderación a la presencia de fuentes de inóculo.

También se han disñado algunos modelos predictivos basados en la correlación entre factores ambientales y la incidencia de peste negra para varios cultivos (Olatinwo et al., 2008, 2009, 2010; Cullbreath et al., 2011). De esa forma, utilizando la precipitación acumulada y la temperatura en primavera temprana combinadas con la fecha de plantación Olatinwo et al. (2008) pudieron explicar el $61 \%$ de la variación en la incidencia de la enfermedad en maní en el sudeste de los EE. UU. Este modelo fue mejorado incluyendo el número de días con lluvia a comienzos de primavera, fechas límites de plantación, los valores de evapotranspiración y los ciclos El Niño/La Niña (Olatinwo et al., 2010). 
Morsello y Kennedy (2005) encontraron diferencias entre grados días acumulados en invierno-primavera y lluvia acumulada que explicarían diferencias entre ataques de peste negra en tabaco. De acuerdo con estos autores, la influencia se daría sobre el ciclo en huéspedes invernales y temprano en primavera, destacando a $S$. media como el más abundante en Carolina del Norte. Chappel et al. (2013) profundizaron en el tema ajustando un modelo que separa el efecto de un ataque importante en la temporada previa seguido de un invierno moderado y húmedo que favorece el solape de fin del cultivo y las malezas de verano-otoño con las malezas de invierno, al igual que su abundancia. Por otra parte, destacan que las temperaturas favorables y pocas precipitaciones en primavera promoverían la trasmisión al cultivo y remarcan la importancia de los efectos climáticos Niño/Niña en determinar estas condiciones.

\section{Aproximación al diseño de un índice de riesgo para peste negra en cultivos de tomate y morrón en invernáculo en la zona sur de Uruguay}

Tomando como base la información experimental colectada, parte de la cual se presentó en esta publicación y los índices ya mencionados en el apartado anterior, podemos indicar algunos aspectos para considerar en el diseño de un índice de riesgo de ocurrencia de peste negra para nuestras condiciones. El objetivo en esta etapa inicial es fundamentalmente una aproximación que ayude en el reconocimiento y valorice las medidas preventivas de manejo priorizando los puntos críticos sobre los que se debería intervenir.

A los efectos mencionaremos algunos parámetros para considerar en dicho índice, a los cuales le asignaremos arbitrariamente tres valores, según su aporte al riesgo sea alto (5), medio (3) o bajo (1):

1) Historia de la enfermedad en el establecimiento o en la zona en la temporada previa $\underline{(H)}$. De acuerdo con nuestra experiencia, existen establecimientos y zonas en las que la ocurrencia e incidencia de la enfermedad es frecuente, posiblemente por un manejo equivocado, por la vegetación existente o la concentración de cultivos susceptibles. Para cuantificar su efecto podríamos decir que existe riesgo alto cuando la enfermedad se registró en el predio la temporada previa, intermedio cuando hubo ataques en la zona y bajo cuando no se tiene conocimiento de la presencia de la enfermedad en la zona. Debemos aclarar que la presencia de la enfermedad a considerar no es solo en tomate o morrón sino incluye a todos los huéspedes susceptibles, incluso malezas. No importa la dimensión del ataque, ya que, como sabemos, cuando se dan las condiciones favorables puede ser fuente del origen de grandes epidemias.

2) Manejo entre cultivos (M). En este parámetro se incluyen el manejo de los restos del cultivo anterior, de huéspedes alternativos dentro y en las inmediaciones del invernáculo, de medidas que contribuyen a la sanidad del suelo (solarización, abonos verdes, etc.). Un valor alto de este parámetro se asignaría a un invernáculo en el cual se deja el cultivo previo abandonado, sin control de malezas ni retiro de restos hasta pocos días antes de la nueva plantación. Medio sería cuando las medidas son realizadas en forma imperfecta (se permiten malezas en paredes o postes, el retiro de restos se hace en forma parcial o son dejados cerca o en superficiel y bajo cuando se aplican todas las herramientas disponibles en forma adecuada. 
3) Condiciones climáticas (temperatura y lluvia) en el período sin cultivo, principalmente en las semanas previas próximas al trasplante (C). Como por el momento no se cuenta con un modelo mediante el cual en base a la información local permita predecir la migración de trips a comienzos de primavera, podemos suponer que un invierno benigno, con pocas precipitaciones en el período pre y post trasplante significaría un riesgo alto de llegada de trips al nuevo cultivo. Riesgo medio se podría establecer cuando, a pesar de las temperaturas benignas, ocurrieron lluvias en ese período y bajo cuando las temperaturas durante el invierno fueron lo suficientemente bajas, con abundantes heladas, para disminuir la presencia de vegetación susceptible y hospederos del vector.

4) Sanidad y calidad de los plantines (S). En este ítem se considera si el cultivar cuenta con algún tipo de resistencia a la enfermedad y si se tomaron las medidas necesarias durante el almácigo para prevenir la infección. Un riesgo alto estaría dado por un origen en el cual ya se ha presentado la enfermedad en la temporada anterior o del cual se desconoce o se desconfía de su manejo sanitario; medio cuando el origen es confiable pero no se aportan datos sobre el manejo y bajo cuando todo lo anterior se cumple satisfactoriamente.

5) Presencia de huéspedes alternativos en floración dentro o en las inmediaciones del invernáculo con el cultivo en sus etapas iniciales (F). En este caso los niveles de riesgo podrían estar dados en cuanto a cantidad, composición lver información de contribución de las diferentes malezas en el ciclo de la enfermedad), cercanía al cultivo y presencia de trips en las flores.

6) Empleo de mallas anti-insecto, plástico foto selectivo, mulch reflectivo, trampas pegajosas y otros métodos mecánicos para disminuir la presencia del vector en el interior (T). El valor máximo de riesgo se asignaría cuando no se emplea ninguna medida, medio cuando solamente se aplican algunas medidas y mínimo cuando el manejo es completo y se traduce en bajas capturas de adultos o nulas en trampas pegajosas en el interior del cultivo.

7) Manejo del vector y de malezas en floración durante el cultivo (V). Si bien es un parámetro difícil de definir y valorar, su efecto está muy ligado a la presencia de la enfermedad (lo cual ya significa que el riesgo definido por los ítems anteriores fue alto) y, como vimos, trasciende a la presente estación de cultivo. Por esa razón es conveniente incluirlo en el índice asignándole un valor alto cuando existe una ocurrencia de poblaciones altas del vector ya sea en flores del cultivo, de malezas o en trampa pegajosa y se observan síntomas en el establecimiento o en la zona, medio cuando a pesar de la presencia del vector no se registran síntomas y bajo cuando la población del vector es baja y no hay indicios de la enfermedad.

De esa forma el índice de riesgo de peste negra (IRPN) podría ser algo como:

$$
\text { IRPN }=\mathrm{H}+\mathrm{M}+\mathrm{C}+\mathrm{S}+\mathrm{F}+\mathrm{T}+\mathrm{V}
$$


Y adquiriría un valor máximo de 35 en las peores condiciones y 7 en las mejores. Por el momento no estamos en condiciones de fijar un límite en el cual comenzaría a existir riesgo $y$, reiteramos, se trata de una primera aproximación que deberá ser ajustada y validada en nuestras condiciones y simplemente busca enfatizar la relevancia de las medidas preventivas para el manejo de esta enfermedad.

\section{CONSIDERACIONES FINALES}

Dada la importancia de esta enfermedad, principalmente en el cultivo de morrón en nuestra zona y su complejidad, la cual esperamos hayamos sido capaces de trasmitir en sus múltiples facetas, para evitar pérdidas es imprescindible que se realice un manejo integrado y preventivo utilizando esa información y todas las medidas disponibles. La situación actual del conocimiento sienta las bases para realizar un manejo racional que sustituya al utilizado en el pasado basado principalmente en la aplicación de insecticidas y que demostró ser totalmente ineficaz y perjudicial.

Seguramente en el futuro inmediato el avance de la ciencia pondrá a disposición nuevas herramientas que permitirán perfeccionar el manejo propuesto, ya algunas de ellas están siendo evaluadas y contribuirán a la producción de estos cultivos de una forma sustentable y segura tanto para el consumidor, trabajador y el medio ambiente.

Por último, a modo de resumen presentamos un cuadro extraído de Jones (2004) el cual hemos tratado de adaptar a nuestras condiciones y pretende condensar la utilidad de muchas de las medidas disponibles para el manejo de la peste negra en tomate y morrón. 
Cuadro 18.Medidas de manejo integrado para minimizar los ataques de peste negra en cultivos hortícolas en tres situaciones: almácigos, cultivos protegidos y a campo (Tomada de Jones, 2004).

\begin{tabular}{|l|c|c|c|}
\hline Medida de manejo & Almácigos & $\begin{array}{c}\text { Cultivos } \\
\text { protegidos }\end{array}$ & $\begin{array}{c}\text { Cultivos } \\
\text { a campo }\end{array}$ \\
\hline $\begin{array}{l}\text { Evitar la diseminación desde cultivos en final de } \\
\text { ciclo }\end{array}$ & & $X$ & $X$ \\
\hline $\begin{array}{l}\text { Evitar la diseminación desde cultivos } \\
\text { ornamentales }\end{array}$ & $\mathrm{X}$ & $\mathrm{X}$ & $\mathrm{X}$ \\
\hline $\begin{array}{l}\text { Minimizar la diseminación desde malezas y } \\
\text { plantas espontáneas }\end{array}$ & $\mathrm{X}$ & $\mathrm{X}$ & $\mathrm{X}$ \\
\hline Erradicación de plantas enfermas en el cultivo & & $\mathrm{X}$ & $\mathrm{X}$ \\
\hline Uso de plantines sanos & & $\mathrm{X}$ & $\mathrm{X}$ \\
\hline Evitar diseminación en el almácigo & $\mathrm{X}$ & & \\
\hline Certificación de plantines' & $\mathrm{X}$ & & \\
\hline Aislamiento de cultivos susceptibles & & $\mathrm{X}$ & $\mathrm{X}$ \\
\hline $\begin{array}{l}\text { Promover cobertura rápida de follaje y plantación } \\
\text { en alta densidad }\end{array}$ & & & $\mathrm{X}$ \\
\hline Manejar la fecha de plantación & & $\mathrm{X}$ & $\mathrm{X}$ \\
\hline Uso de mulch reflectivo o laboreo mínimo & & & $\mathrm{X}$ \\
\hline Uso de cortinas, barreras o abonos verdes & & $\mathrm{X}$ & $\mathrm{X}$ \\
\hline Disminuir el crecimiento de la población del vector & $\mathrm{X}$ & $\mathrm{X}$ & \\
\hline Instalar mallas anti-insectos y plástico filtro UV & $\mathrm{X}$ & $\mathrm{X}$ & \\
\hline Sistema de advertencia de ataques & & $\mathrm{X}$ & $\mathrm{X}$ \\
\hline $\begin{array}{l}\text { Instalar un período libre de cultivos y malezas } \\
\text { (“vacío sanitario") }\end{array}$ & $\mathrm{X}$ & $\mathrm{X}$ & $\mathrm{X}$ \\
\hline Uso de cultivares resistentes & $\mathrm{X}$ & $\mathrm{X}$ & $\mathrm{X}$ \\
\hline Aplicación de insecticidas & & $\mathrm{X}$ \\
\hline $\begin{array}{l}\text { Aplicación de aceites o productos formadores de } \\
\text { películas }\end{array}$ & $\mathrm{X}$ & \\
\hline Introducción de enemigos naturales de trips & & & \\
\hline
\end{tabular}

${ }^{1}$ Es un procedimiento que existe en EE.UU. no solo para esta enfermedad ya que los plantines se producen en el sur y de allí son distribuidos a todo el país.

2 Método eficaz en cultivos a campo cuando existe un solo ciclo de infección.

${ }^{3}$ Como se mencionó en el texto, existen sistemas de advertencia en algunas zonas de los EE.UU.

${ }^{4}$ Como se mencionó en el texto, el control del vector en cantidad no asegura el éxito en la prevención de peste negra, solo deberá ser aplicada en situaciones límites y de forma segura. 


\section{Bibliografia}

1. ABE, H.; TOMITAKA, Y.; SHIMODA, T.; SEO, S.; SAKURAI, T.; KUGIMIYA, S.; TSUDA, S.; KOBAYASHI, M. 2012. Antagonistic plant defense system regulated by phytohormones assists interactions among vector insect, thrips and a tospovirus. Plant Cell Physiology, 53(1): 204-212

2. ABDULLAH, Z.S.; GREENFIELD, B.P.J.; FICKEN, K.J.; TAYLOR, J.W.D.; WOOD, M.; BUTT, T.M. 2015. A new attractant for monitoring western flower thrips, Frankliniella occidentalis in protected crops. SpringerPlus, 4:89

3. ADAM, G.; YEH, S.D.; REDDY, D.V.R.; GREEN, S.K. 1993. Serological comparison of Tospovirus isolates from Taiwan and India with Impatiens necrotic spot virus and different Tomato spot wilt virus isolates. Archives of Virology, 130: 237-250

4. ADAMS, M.J.; LEFKOWITZ, E.J.; KING, A.M.Q.; HARRACH, B.; HARRISON, R.L.; KNOWLES, N.J.; KROPINSKI, A.M.; KRUPOVIC, M.; KUHN, J.H.; MUSHEGIAN, A.R.; NIBERT, M.; SABANADZOVIC, S.; SANFAÇON, H.; SIDDELL, S.G.; SIMMONDS, P.; VARSANI, A.; MURILO ZERBINI, F.; GORBALENYA, A.E.; DAVISON, A.J. 2017. Changes to taxonomy and the International Code of Virus Classification and Nomenclature ratified by the International Committee on Taxonomy of Viruses. Archives of Virology, 162:2505-2538

5. ADKINS, S. 2000. Tomato spotted wilt virus-positive steps towards negative success. Molecular Plant Pathology, 1:151-157

6. ALLEN, W.R.; MATTEOINI, J.A. 1991. Petunia as an indicator plant for use by growers to monitor for thrips carrying the tomato spotted wilt virus in greenhouses. Plant Disease, 75:78-82

7. ALLEN, W.R.; TEHRANI, B.; LUFT, R. 1993. Effect of horticultural oil, insecticidal soap, and film-forming products on the western flower thrips and the tomato spotted wilt virus. Plant Disease, 77:915-918

8. ANANTHAKRISHNAN, T.N.; ANNADURAI, R.S. 2007. Thrips-tospovirus interactions: Biological and molecular implications. Current Science, 92 (8):1083-1086

9. ANTIGNUS, Y.; MOR, N.; BEN JOSEPH, R.; LAPIDOT, M.; COHEN, S. 1996. Ultraviolet absorbing plastic sheets protect crops from insect pests and from virus diseases vectored by insects. Environmental Entomology, 25: 919-924

10. ANTIGNUS, Y.; BEN-YAKIR, D. 2004. Ultraviolet-absorbing barriers, an efficient integrated pest management tool to protect greenhouses from insects and virus diseases. En: Horowitz A.R.; Ishaaya I. (eds) Insect Pest Management. Springer, Berlin. Heidelberg.

11. ARAMBURU, J.; RIUDAVETS, J.; ARNO, J.; LAVIÑA, A.; MORIONES, E. 1996. Rapid serological detection of Tomato spotted wilt virus in individual thrips by squash-blot assay for use in epidemiological studies. Plant Pathology, 45:367-374 
12. ARAMBURU, J.; RIUDAVETS, J.; ARNO, J.; LAVIÑA, A.; MORIONES, E. 1997. The proportion of viruliferous individuals in field populations of Frankliniella occidentalis: Implications for Tomato spotted wilt virus epidemics in tomato. European Journal of Plant Pathology, 103: 623-629

13. ARAMBURU, J.; RODRIGUEZ, M. 1999. Evaluation of commercial Lycopersicon esculentum hybrids for resistance to Tomato spotted wilt tospovirus (TSWV) in Spain. Journal of Horticultural Science and Biotechnology, 74(6):743-747

14. ARAMBURU, J.; RODRIGUEZ, M.; ARIÑO, J. 2000. Effect of Tomato Spotted Wilt Tospovirus (TSWV) infection on the fruits of tomato (Lycopersicon esculentum) plants of cultivars carrying the Sw-5 gene. Journal of Phytopathology, 37:458-463

15. ARAMBURU, J.; MARTí, M. 2003. The occurrence in north-east Spain of a variant of Tomato spotted wilt virus (TSWV) that breaks resistance in tomato (Lycopersicon esculentum) containing the Sw-5 gene. Plant Pathology, 52:407

16. ARAMBURU, J.; LÓPEZ, C.; GALIPIENSO, L.; SOLER, S.; NUEZ, F. 2007. La enfermedad del bronceado en tomate y pimiento: Un problema permanente en una situación cambiante. Phytoma España, 194:24-29

17. ARAMBURU, J.; GALIPIENSO, L.; SOLER, S.; LÓPEZ, C. 2010. Characterization of Tomato spotted wilt virus isolates that overcome the $S w-5$ resistance gene in tomato and fitness assays. Phytopathologia Mediterranea, 49:342-351

18. ARAMBURU, J.; GALIPIENSO, L.; SOLER, S.; RUBIO, L.; LÓPEZ, C. 2015. A severe symptom phenotype in pepper cultivars carrying the TsW resistance gene is caused by a mixed infection between resistance-breaking and non-resistance-breaking isolates of Tomato spotted wilt virus. Phytoparasitica, 43:597-605

19. ARNó, J.; RIUDAVETS, J.; MORIONES, E. 1995. Monitoring Western flower thrips as a Tomato spotted wilt virus vector in tomato. En: B. L. Parker et al. (eds.), Thrips Biology and Management. Springer Science Business Media New York 1995. p 197-200

20. ARRUABARRENA, A.; GONZÁLEZ-ARCOS, M.; RUBIO, L.; GIMÉNEZ, G. 2015. Selección asistida por marcadores en el mejoramiento genético de tomate. Biotecnología para el sector productivo. Revista INIA Uruguay, 40:43-46

21. ATAKAN, E.; KAMBEROĞLU, M.A.; UYGUR, S. 2013. Role of weed hosts and the western flower thrips, Frankliniella occidentalis, in epidemiology of Tomato spotted wilt virus in the Cukurova region of Turkey. Phytoparasitica, 41:577-590

22. BAC-MOLENAAR, J.A.; MOL, S.; VERLAAN, M.G.; VAN ELVEN, J.; KIM, H.K.; KLINKHAMER, P.G.L.; LEISS, K.A.; VRIELING, K. 2019. Trichome Independent Resistance against Western Flower Thrips in Tomato. Plant Cell Physiololgy, 60(5): 1011-1024

23. BADILLO-VARGAS, I.E.; ROE, N.; FUNDERBURK, J.E.; ADKINS, S. 2015. First report of Tomato chlorotic spot virus in scarlett eggplant (Solanum aethiopicum) and American black nightshade (Solanum americanum) in the United States. Plant Disease, 99:1450 
24. BAEZ, I.; REITZ, S.R.; FUNDERBURK, J.E. 2004. Predation by Orius insidiosus (Heteroptera: Anthocoridae) on Life Stages and Species of Frankliniella Flower Thrips (Thysanoptera: Thripidae) in Pepper Flowers. Environmental Entomology, 33(3): 662670

25. BAKER, C.A.; ADKINS, S. 2015. First report of Tomato chlorotic spot virus in Hoya wayetii and Schlumbergera truncate. Plant Health Progress, 16:29-30

26. BANDLA, M.D.; WESTCOT, D.M.; CHENAULT, K.D.; ULLMAN, D.E.; GERMAN, T.L.; SHERWOOD, J.L. 1994. Use of monoclonal antibody to the non-structural protein encoded by the small RNA of tomato spotted wilt tospovirus to identify viruliferous thrips. Phytopathology, 84: 1427-1431

27. BANDLA, M.D.; CAMPBELL, L.R.; ULLMAN, D.E.; SHERWOOD, J.L. 1998. Interaction of tomato spotted wilt tospovirus (TSWV) glycoproteins with a thrips midgut protein, a potential cellular receptor for TSWV. Phytopathology, 88: 98-104

28. BATUMAN, 0.; TURINI, T.A.; OLIVEIRA, P.V.; ROJAS, M.R.; MACEDO, M.; MELLINGER, H.C.; ADKINS, S.; GILBERTSON, R.L. 2017. First Report of a Resistance-Breaking Strain of Tomato spotted wilt virus infecting tomatoes with the Sw-5 Tospovirus-resistance gene in California. Plant Disease, 101(4):637

29. BAUTISTA, R. C.; MAU, R. F. L. 1994. Preferences and development of western flower thrips (Thysanoptera: Thripidae) on plant hosts of tomato spotted wilt tospovirus in Hawaii. Environmental Entomology, 23:1501-1507

30. BAUTISTA, R.C.; MAU, R.F.L.; CHO, J.J.; CUSTER, D.M. 1995. Potential of tomato spotted wilt tospovirus plant hosts in Hawaii as virus reservoirs for transmission by Frankliniella occidentalis (Thysanoptera: Thripidae. Phytopathology, 85: 953-958

31. BEAUDOIN, A.L.P.; KAHN, N.D.; KENNEDY, G.G. 2009. Bell and banana pepper exhibit mature-plant resistance to Tomato spotted wilt tospovirus transmitted by Frankliniella fusca (Thysanoptera: Thripidae). Journal of Economic Entomology, 102(1):30-35

32. BELL, M.L.; BAKER, J.R. 2000. Comparison of greenhouse screening materials for excluding whitefly (Homoptera: Aleyrodidae) and thrips (Thysanoptera: Thripidae). Journal of Economical Entomology, 93(3):800-804

33. BERIS, D.; THEOLOGIDIS, I.; SKANDALIS, N.; VASSILAKOS, N. 2018. Bacillus amyloliquefaciens strain MBI600 induces salicylic acid dependent resistance in tomato plants against Tomato spotted wilt virus and Potato virus Y. Scientific Reports, 8:10320. DOI:10.1038/s41598-018-28677-3

34. BERNAL, R.; MAESO, D.; FEDERICCI, M.T.; WALASEK, W. 2007. Identificación de virus en cultivos protegidos en las zonas de Salto y Bella Unión. En: Sanidad en cultivos protegidos en la zona norte de Uruguay. Salto: INIA Salto Grande. p 13-15. (Serie Actividades Difusión; 517) 
35. BERTELLI, J.; KOCH DE BERTELLI, L. 1944. Notas fitopatológicas. Primer agregado a la lista de enfermedades y plagas principales de la agricultura uruguaya. Cartilla Nº70. Dirección de Agronomía. Ministerio de Ganadería y Agricultura.

36. BEZERRA, I.C.; RESENDE, R.0.; POZZER, L.; NAGATA, T.; KORMELINK, R.; DE ÁVILA, A.C. 1999. Increase of tospoviral diversity in Brazil with the identification of two new tospovirus species, one from Chrysanthemum and one from zucchini. Phytopathology, 89:823-830

37. BITTERLICH, I.; MACDONALD, L.S. 1993. The prevalence of Tomato spotted wilt virus in weeds and crop plants in south western British Columbia. Canadian Plant Disease Survey, 72:137-142

38. BOONHAM, N.; SMITH, P.; WALSH, K.; TAME, J.; MORRIS, J.; SPENCE, N.; BENNISON, J.; BARKER, I. 2002. The detection of Tomato spotted wilt virus (TSWV) in individual thrips using real time fluorescent RT-PCR (TaqMan). Journal of Virological Methods, 101:37-48

39. BELLENDA, B.; GUARINONI, A. 1985. Binomía de Frankliniella schultzei (Trybon) (Thysanoptera: Thripidae) y variación estacional de especies de trips asociadas al cultivo de tomate. Tesis Ing. Agr. Montevideo, Uruguay. Facultad de Agronomía. 85 p.

40. BEN-MAHMOUD, S.; ANDERSON, T.; CHAPPELL, T.M.; SMEDA, J.R.; MUTSCHLER, M.A.; KENNEDY, G.G.; DE JONG, D.M.; ULLMAN, D.E. 2019. A thrips vector of Tomato spotted wilt virus responds to tomato acylsugar chemical diversity with reduced oviposition and virus inoculation. Scientific reports. 9:17157. Consultado agosto 2020. Disponible en https://doi.org/10.1038/s41598-019-53473-y.

41. BITTERLICH, I.; MACDONALD, L.S. 1993. The prevalence of Tomato spotted wilt virus in weeds and crops in southwestern British Columbia. Canadian Plant Disease Survey, 73:137-142

42. BLACK, L.L.; HOBBS, H.A.; GATTI, J.M. 1991. Tomato spotted wilt virus resistance in Capsicum chinense PI152225 and 159236. Plant Disease, 75:863

43. BOITEAU, G.; VERNON, R.S. 2001. Physical barriers for the control of insect pests. En: Physical Control Methods in Plant Protection. Ed. Vincent, C. y Fleurat-Lessard, P.F. pp 224-247. Springer-Verlag Berlin Heidelberg.

44. BOITEUX, L.S.; NAGATA, T.; DUTRA, W.E.; FONSECA, M.E.N. 1993. Sources of resistance to Tomato spotted wilt virus (TSWV) in cultivated and wild species of Capsicum. Euphytica, 67: 89-94

45. BOITEUX, L.S.; GIORDANO, L. DE B. 1993. Genetic basis of resistance against two Tospovirus species in tomato (Lycopersicon esculentum). Euphytica, 71:151-154

46. BOITEUX, L.S.; DE ÁVILA, A.C. 1994. Inheritance of a resistance specific to tomato spotted wilt tospovirus in Capsicum chinense 'PI 159236'. Euphytica, 75:139-142 
47. BOITEUX, L.S. 1995. Allelic relationships between genes for resistance to tomato spotted wilt tospovirus in Capsicum chinense. Theoretical Applied Genetics, 90:146-149

48. BOND, W.P.; WHITAM, H.K.; BLACK, L.L. 1983. Indigenous weeds as reservoirs of Tomato spotted wilt virus in Louisiana. Phytopathology, 73:499

49. BOONHAM, N.; SMITH, P.; WALSH, K.; TAME, J.; MORRIS, J.; SPENCE, N.; BENNISON, J.; BARKER, I. 2002. The detection of Tomato spotted wilt virus (TSWV) in individual thrips using real time fluorescent RT-PCR (TaqMan). Journal of Virological Methods, 101:37-48

50. BOSCO, L.; GIACOMETTO, E.; TAVELLA, L. 2008. Colonization and predation of thrips (Thysanoptera: Thripidae) by Orius spp. (Heteroptera: Anthocoridae) in sweet pepper greenhouses in Northwest Italy. Biological Control, 44:331-340

51. BRIOZZO, J. 1982. Especies de Thripidae (Thysanoptera) de interés económico en horticultura. Investigaciones Agronómicas, 3 (1): 85-86

52. BRITTLEBANK, C. C. 1919. Tomato diseases. Journal of Agriculture, Victoria, 27:231-235

53. BROADBENT, A.B.; MATTEONI, J.A.; ALLEN, W.R. 1990. Feeding preferences of the western flower thrips Frankliniella occidentalis (Pergande) (Thysanoptera: Thripidae), and incidence of Tomato spotted wilt virus among cultivars of florist's chrysanthemum. Canadian Entomologist, 122 (6):1111-1117

54. BROMMONSCHENKEL, S.H.; FRARY, A.; FRARY, A.; TANKSLEY, S.D. 2000. The BroadSpectrum Tospovirus resistance gene Sw-5 of tomato is a homolog of the root-knot nematode resistance gene Mi. Molecular Plant Microbe Interactions, 13 (10):1130-1138

55. BROWN, S.L.; CULBREATH, A.K.; TODD, J.W.; GORBET, D.W.; BALDWIN, J.A.; BEASLEY JR.; J.P. 2005. Development of a method of risk assessment to facilitate integrated management of spotted wilt of peanut. Plant Disease, 89:348-352

56. BRUNNER, P.C.; CHATZIVASSILIOU, E.K.; KATIS, N.I.; FREY, J.E. 2004. Host associated genetic differentiation in Thrips tabaci (Insecta; Thysanoptera), as determined from mtDNA sequence data. Heredity, 93:364-370

57. BUCHER, E.; SIJEN, T.; DE HAAN, P.; GOLDBACH, R.; PRINS, M. 2003. Negative strand tospoviruses and tenuiviruses carry a gene for a suppressor of gene silencing at analogous genomic positions. Journal of Virology, 77:1329-1336

58. BUENAHORA, J.; TADEO, A.; GALVÁN, V. 2003a. Efecto del control físico de adultos de mosca blanca mediante el uso de cintas plásticas amarillas con pegante. En: Jornada de Protección Vegetal en Horticultura. Salto: INIA Salto Grande. pp 3-8. (Serie de actividades de difusión; 345)

59. BUENAHORA, J.; TADEO, A.; GALVÁN, V. 2003b. Evolución de la población de plagas en cultivo de morrón en invernadero bajo polietileno foto selectivo. En: Jornada de Protección Vegetal en Horticultura. Salto: INIA Salto Grande. pp 9-23. (Serie de actividades de difusión; 345) 
60. BUENAHORA, J.; BERNAL, R.; GALVAN, V.; AMARAL, J. 2009. Efecto del uso de mallas anti-insectos sobre el control de plagas y el ambiente en un cultivo de tomate en invernadero. En: Sanidad en Cultivos Protegidos y Cultivares de Tomate de Mesa. Montevideo: INIA Las Brujas. pp23-26. (Serie Actividades de Difusión; 598)

61. BUENAHORA, J. 2014. Utilización de Amblyseius swirskii Athias-Henriot (Acari: Phytoseiidae), un enemigo natural clave para el manejo integrado de plagas en el cultivo de pimiento en invernadero. Tesis de Maestría. Facultad de Agronomía. Universidad de la República. Uruguay. 125 p.

62. CAMANN, M.A.; CULBREATH, A.K.; PICKERING, J.; TODD, J.W.; DEMSKI, J.W. 1995. Spatial and temporal patterns of spotted wilt epidemics in peanut. Phytopathology, 85:879-885

63. CANADY, M.A.; STEVENS, M.R.; BARINEAU, M.S.; SCOTT, J.W. 2001. Tomato spotted wilt virus (TSWV) resistance in tomato derived from Lycopersicon chilense Dun. LA 1938. Euphytica, 117: 19-25

64. CARBONELL, A.; LÓPEZ, C.; DARÓS, J.A. 2019. Fast-forward identification of highly effective artificial small RNAs against different Tomato spotted wilt virus isolates. Molecular plant microbe interactions, 32(2):142-156

65. CARRIZO, P.I.; AMELA GARCíA, M.T. 2017. Vegetación espontánea en el cinturón hortícola platense hospedante de Thripidae (Thysanoptera) vectores de Tospovirus. RIA, $43(1): 78-90$.

66. CHAISUEKEL, C.; RILEY, D.G. 2001. Thrips feeding response to concentration of imidacloprid in tomato leaf tissue. Journal of Entomological Science, 36:315-317

67. CHAISUEKUL, C.; RILEY, D.G.; PAPPU, H. R. 2003. Transmission of Tomato spotted wilt virus to Tomato Plants of Different Ages. Journal of Entomological Science, 38(1):127136

68. CHAISUEKUL, C.; RILEY, D.G. 2005. Host Plant, Temperature, and Photoperiod Effects on Ovipositional Preference of Frankliniella occidentalis and Frankliniella fusca (Thysanoptera: Thripidae). Journal of Economical Entomology, 98(6): 2107-2113

69. CHAMBERLIN, J. R.; TODD, J. W.; BESHEAR, R. J.; CULBREATH, A. K.; DEMSKI, J. W. 1992. Overwintering hosts and wing form of thrips, Frankliniella spp.; in Georgia (Thysanoptera: Thripidae): implications for management of spotted wilt disease. Environmental Entomology, 21 (1):121-128

70. CHAMBERLIN, J.R.; CULBREATH, A.K.; TODD, J.W.; DEMSKI, J.W. 1993. Detection of Tomato spotted wilt virus in tobacco thrips (Thysanoptera: Thripidae) overwintering in harvested peanut fields. Journal of Economical Entomology, 86:40-45

71. CHAPPELL, T.M.; BEAUDOIN, A.L.P.; KENNEDY, G.G. 2013. Interacting virus abundance and transmission intensity underlie Tomato spotted wilt virus incidence: An example weather-based model for cultivated tobacco. PLoS ONE, 8(8): e73321 doi:10.1371/journal.pone.0073321 
72. ChatZivassilioU, E.K.; NAGATA, T.; KATIS, N.I.; PETERS, D. 1999. Transmission of tomato spotted wilt tospovirus by Thrips tabaci populations originating from leek. Plant Pathology, 48: 700-706

73. CHATZIVASSILIOU, E. K.; BOUBOURAKAS, I.; DROSSOS, E.; ELEFTHEROHORINOS, I.; JENSER, G.; PETERS, D.; KATIS, N. I. 2001. Weeds in greenhouses and tobacco fields are differentially infected by Tomato spotted wilt virus and infested by its vector species. Plant Disease, 85:40-46

74. ChatZiVASSilioU, E. K.; PETERS, D.; KATIS, N. I. 2002. The efficiency by which Thrips tabaci populations transmit Tomato spotted wilt virus depends on their host preference and reproductive strategy. Phytopathology, 92:603-609

75. ChATZIVASSILIOU, E.K.; PETERS, D.; KATIS, N.I. 2007. The role of weeds in the spread of Tomato spotted wilt virus by Thrips tabaci (Thysanoptera: Thripidae) in tobacco crops. Journal of Phytopathology, 155:699-705

76. CHATZIVASSILIOU, E. K. 2008. Management of the spread of Tomato spotted wilt virus in tobacco crops with insecticides based on estimates of thrips infestation and virus incidence. Plant Disease, 92:1012-1020

77. CHELLEMI, D.0.; FUNDERBURK, J.E.; HALL, D.W. 1994. Seasonal abundance of flower-inhabiting Frankliniella species (Thysanoptera: Thripidae) on wild plant species. Environmental Entomology, 23(2):337-342

78. CHENG, Y.H.; ZHENG, Y.X.; TAI, C.H.; YEN, J.H.; CHEN, Y.K.; JAN, F.J. 2014. Identification, characterization and detection of a new tospovirus on sweet pepper. Annals of Applied Biology, 164:107-115

79. CHERRY, K.R.; MILA, A.L. 2011. Temporal progress and control of Tomato spotted wilt virus in flue-cured tobacco. Crop Protection, 30:539-546

80. CHO, J.J.; MAU, R.F.L.; HAMASAKI, R.T.; GONSALVES, D. 1986. Detection of Tomato spotted wilt virus in individual thrips by enzyme-linked immunosorbent assay. Phytopathology, 78:1348-1352

81. CHO, J. J.; MAU, R. F. L.; GONSALVES, D.; MITCHELL, W. C. 1986b. Reservoir weed hosts of tomato spotted wilt virus. Plant Disease, 70:1014-1017

82. CHO, J. J.; MITCHELL, W. C.; MAU, R. F. L.; SAKIMURA, K. 1987. Epidemiology of Tomato spotted wilt virus on crisp head lettuce in Hawaii. Plant Disease, 71 :505-508

83. CHO, J.J.; MAU, T.L.; GERMAN, R.F.L.; HARTMAN, R.W.; YUDIN, L.S.; GONSALVES, D.; PROVVIDENTI, R. 1989. A multidisciplinary approach of Tomato spotted wilt virus in Hawaii. Plant Disease, 73:375-383

84. CHO, K.; ECKEL, C.S.; WALGENBACH, J.F.; KENNEDY. G.G. 1995. Comparison of colored sticky traps for monitoring thrips populations (Thysanoptera: Thripidae) in staked tomato fields. Journal of Entomological Science, 30: 176-190 
85. CHO, J.J.; CUSTER, D.M.; BROMMONSCHENKEL, S.H.; TANKSLEY, S.D. 1996. Conventional breeding: host-plant resistance to tomato spotted wilt in vegetables. Acta Horticulturae, 431:367-378

86. CHUNG, B.N.; LEE, J.H.; KANG, B.C.; KOH, S.W.; JOA, J.H.; CHOI, K.S.; AHN, J.J. 2018. HR-Mediated Defense Response is Overcome at High Temperatures in Capsicum Species. Plant Pathology Journal, 34(1): 71-77

87. CIUFFO, M.; FINETTI-SIALER, M.M.; GALLITELLI, D.; TURINA, M. 2005. First report in Italy of a resistance-breaking strain of Tomato spotted wilt virus infecting tomato cultivars carrying the $S_{w}-5$ resistance gene. Plant Pathology, 54:564.

88. CLIFT, A.D.; CANNARD, M.; RYLAND, A. 2000. Management of thrips and TSWV in the Sydney Basin. Western Flower Thrips Newsletter, 20:18-22

89. CLIFT, A.D.; TESORIERO, L. 2001. Aspects of vector thrips biology and epidemiology of tospoviruses in Australia. En: Thrips and tospoviruses: Proceedings of the 7th International Symposium on Thysanoptera. Editors: Rita Marullo, Laurence Mound. pp 87-89

90. COUTTS, B.A.; THOMAS-CARROL, M.L.; JONES, R.A.C. 2004. Patterns of spread of Tomato spotted wilt virus in field crops of lettuce and pepper: spatial dynamics and validation of control measures. Annals of Applied Biology, 145:231-245

91. CSINOS, A.; PAPPU, H.; MCPHERSON, R.; STEPHENSON, M. 2001. Management of Tomato spotted wilt virus in flue-cured tobacco with acibenzolar-S-methyl and imidacloprid. Plant Disease, 85:292-296

92. CSIZINSZKY , A.A. ; SCHUSTER, D.J.; KRING, J.B. 1995. Color Mulches Influence Yield and Insect Pest Populations in Tomatoes. Journal of American Society of Horticultural Science, 120(5):778-784

93. CULBREATH, A.K.; CSINOS, A.S.; BERTRAND, P.F.; DEMSKI, J.W. 1991. Tomato spotted wilt virus epidemic in flue-cured tobacco in Georgia. Plant Disease, 75:483-485

94. CULBREATH, A.K.; TODD, J.W.; BROWN, S.L.; BALDWIN, J.A.; PAPPU, H.R. 1999. A genetic and cultural package for management of Tomato spotted wilt virus in peanut. Biological and Cultural Tests for Control Plant Diseases, 14:1-8

95. CULBREATH, A.K.; TODD, J.W.; BROWN, S.L. 2003. Epidemiology and management of tomato spotted wilt in peanut. Annual Review of Phytopathology, 41: 53-75

96. CULBREATH, A. K.; TILLMAN, B. L.; TUBBS, R. S.; BEASLEY JR.; J. P.; KEMERAIT JR.; R. C.; BRENNEMAN, T. B. 2010. Interactive effects of planting date and cultivar on tomato spotted wilt of peanut. Plant Disease, 94:898-904

97. CULBREATH, A. K.; SRINIVASAN, R. 2011. Epidemiology of spotted wilt disease of peanut caused by Tomato spotted wilt virus in the southeastern U.S. Virus Research, 159:101-109 
98. DAL Bó, E. 2011. Detección de virus transmitidos por trips: el caso particular de Argentina. Métodos en Ecología y Sistemática, 6(3): 27-32

99. DAVIDSON, M.M.; BUTLER, R.C.; WINKLER, S.; TEULON, D.A.J. 2007. Pyridine compounds increase trap capture of Frankliniella occidentalis (Pergande) in a covered crop. New Zealand Plant Protection, 60:56-60

100. DEANGELIS, J.D.; SETHER, D.M.; ROSSIGNOL, P.A. 1993. Survival development and reproduction in western flower thrips (Thysanoptera: Thripidae) exposed to impatiens necrotic spot virus. Environmental Entomology, 22: 1308-1312

101. DE ASSIS FILHO, F.M.; NAIDU, R.A.; DEOM, C.M.; SHERWOOD, J.L. 2002. Dynamics of Tomato spotted wilt virus replication in the alimentary canal of two thrips species. Phytopathology, 92: 729-733

102. DE ASSIS FILHO, F.M.; DEOM, C.M.; SHERWOOD, J.L. 2004. Acquisition of tomato spotted wilt virus by adults of two thrips species. Phytopathology, 94: 333-336

103. DE ÁVILA, A.C.; HUGUENOT, C.; RESENDE, R. DE O.; KITAJIMA, E.W.; GOLDBACH, R.; PETERS, D. 1990. Serological differentiation of 20 isolates of tomato spotted wilt virus. Journal of General Virology, 71:2801-2807

104. DE ÁVILA, A.C.; DE HAAN, P. KITAJIMA, E.W.; KORMELINK, R.; RESENDE, R. DE 0.; GOLDBACH, R.W.; PETERS, D. 1992. Characterization of a distinct isolate of tomato spotted wilt virus (TSWV) from Impatiens sp. in the Netherlands. Journal of Phytopathology, 134:133-151

105. DE ÁVILA A.C.; DE HAAN, P.; KORMELINK, R.; RESENDE, R.O.; GOLDBACH, R.W.; PETERS, D. 1993. Classification of tospoviruses based on phylogeny of nucleoprotein gene sequences. Journal of General Virology, 74:153-159

106. DE ÁVILA, A.C.; DE HAAN, P.; SMEETE, M.L.L.; RESENDE, R.O.; KORMELINK, R.; KITAJIMA, E.W.; GOLDBACH, R.W.; PETERS, D. 1993b. Distinct levels of relationship between tospovirus isolates. Archives of Virology, 128:211-227

107. DE BORBÓN, C.M.; GRACIA, O.; PICCOLO, R. 2006. Relationships between Tospovirus incidence and thrips populations on tomato in Mendoza, Argentina. Journal of Phytopathology, 154:93-99

108. DEBRECZENI, D.E.; RUIZ-RUIZ, S.; ARAMBURU, J.; LÓPEZ, C.; BELLIURE, B.; GALIPIENSO, L.; SOLER, S.; RUBIO, L. 2011. Detection, discrimination and absolute quantitation of tomato spotted wilt virus isolates using real time RT-PCR with TaqMan $® M G B$ probes. Journal of Virological Methods, 176:32-37

109. DEBRECZENI, D.E.; RUBIO, L.; ARAMBURU, J.; LÓPEZ, C.; GALIPIENSO, L.; SOLER, S.; BELLIURE, B.B. 2014. Transmission of tomato spotted wilt virus isolates able and unable to overcome tomato or pepper resistance by its vector Frankliniella occidentalis. Annals of Applied Biology, 164:182-189 
110. DEBRECZENI, D.E.; LÓPEZ, C.; ARAMBURU, J.; DARÓS, J.A.; SOLER, S.; GALIPIENSO, L.; FALK, B.W.; RUBIO, L. 2015. Complete sequence of three different biotypes of tomato spotted wilt virus (wild type, tomato Sw-5 resistance-breaking and pepper Tsw resistance-breaking) from Spain. Archives of Virology, 160:2117-2123

111. DE BREUIL, S.; CAÑIZARES, J.; BLANCA, J.M.; BEJERMAN, N.; TRUCCO, V.; GIOLITTI, F.; ZIARSOLO, P.; LENARDON, S. 2016. Analysis of the coding-complete genomic sequence of Groundnut ringspot virus suggests a common ancestor with tomato chlorotic spot virus. Archives of Virology, 161:2311-2316

112. DE HAAN, P.; WAGEMAKERS, L.; PETERS, D. , GOLDBACH, R. 1990. The S RNA segment of tomato spotted wilt virus has an ambisense character. Journal of General Virology, 71:1001-1007

113. DE HAAN, P.; KORMELINK, R. RESENDE, R. DE 0.; VAN POCLWIJK, F.; PETERS D.; GOLDBACH, R. 1991. Tomato spotted wilt virus L RNA encodes a putative RNA polymerase. Journal of General Virology, 72:2207-2216

114. DE OLIVEIRA, A.S.; BOITEUX, L.S.; KORMELINK, R.; RESENDE, R.O. 2018. The Sw-5 gene cluster: Tomato breeding and research toward orthotospovirus disease control. [En línea] Frontiers in Plant Science, 9:1055. Consultado el 9/9/2020. Disponible en: https://www.frontiersin.org/articles/10.3389/fpls.2018.01055/full

115. DE RONDE, D.; BUTTERBACH, P.; LOHUIS, D.; HEDIL, M.; VAN LENT, J.W.M.; KORMELINK, R. 2013. Tsw gene-based resistance is triggered by a functional RNA silencing suppressor protein of the Tomato spotted wilt virus. Molecular Plant Pathology, 14(4):405-415

116. DE SANTIS L. 1995. La presencia en la República Argentina del trips californiano de las flores, Frankliniella occidentalis (Pergande). Anales de la Academia Nacional de Agronomía y Veterinaria, 49: 7-18.

117. DEWEY, R.; SEMORILE, L.; GRAU, 0. 1996. Detection of Tospovirus species by RT-PCR of the $\mathrm{N}$-gene and restriction enzyme digestions of the products. Journal of Virological Methods, 56 (1):19-26

118. DÍAZ-PÉREZ, J.C.; GITAITIS, R.; MANDAL, B. 2007. Effects of plastic mulches on root zone temperature and on the manifestation of tomato spotted wilt symptoms and yield of tomato. Scientia Horticulturae, 114:90-95

119. DIANESE, E.C.; DE FONSECA, M.E.N.; GOLDBACH, R.; KORMELINK, R.; INOUE-NAGATA, A.K.; RESENDE, R.0.; BOITEUX, L.S. 2010. Development of a locus-specific, co-dominant SCAR marker for assisted-selection of the Sw-5 (Tospovirus resistance) gene cluster in a wide range of tomato accessions. Molecular Breeding, 25:133-142

120. DIANESE, E.C.; DE FONSECA, M.E.N.; INOUE-NAGATA, A.K.; RESENDE, R.0.; BOITEUX, L.S. 2011. Search in Solanum (section Lycopersicon) germplasm for sources of broad-spectrum resistance to four Tospovirus species. Euphytica, 180:307-319 
121. DIETZGEN, R.G.; TWIN, J.; TALTY, J.; SELLADURAI, S.; CARROL, M.L.; COUTT, B.A.; BERRYMAN, D.I.; JONES, R.A.C. 2005. Genetic variability of tomato spotted wilt virus in Australia and validation of real time RT-PCR for its detection in single and bulked leaf samples. Annals of Applied Biology, 146:517-530

122. DIEZ, M.J.; ROSELló, S.; NUEZ, F.; COSTA, J.; LACASA, A.; CATALÁ, M.S. 1999. Tomato production under mesh reduces crop los to tomato spotted wilt virus in some cultivars. HortScience, 34(4):634-637

123. DI RIENZO, V.; BUBICI, G.; MONTEMURRO, C.; CILLO, F. 2018. Rapid identification of tomato $S w-5$ resistance-breaking isolates of tomato spotted wilt virus using high resolution melting and TaqMan SNP Genotyping assays as allelic discrimination techniques. [En línea]. PLoS ONE, 13(4): e0196738. Consultado el 9/9/2020. Disponible en https:// doi.org/10.1371/journal.pone.0196738.

124. DOEDERLEIN, T. A.; AND SITES, R. W. 1993. Host plant preferences of Frankliniella occidentalis and Thrips tabaci (Thysanoptera: Thripidae) for onions and associated weeds on the Southern high plains. Journal of Economic Entomology, 86:1706-1713

125. EBRATT, E.E.; ACOSTA, R.; MARTÍNEZ; O.Y.; GUERRERO; O.; TURIZO, W. 2013. Tomato spotted wilt virus (TSWV), weeds and thrips vectors in the tomato (Solanum lycopersicum L.) in the Andean region of Cundinamarca (Colombia). Agronomía Colombiana, 31(1):58-67

126. EIRAS, M.; RESENDE, R.0.; MISSIAGGIA, A.A.; DE ÁVILA, A.C. 2001. RT-PCR and Dot Blot hybridization for an universal detection of tospoviruses. Fitopatologia Brasileira, 26:170-175

127. EPPO. 1998. EPPO data sheets on quarantine pests. Tomato spotted wilt tospovirus. [En línea]. Consultado 20/9/2020. Disponible en

https://gd.eppo.int/download/doc/265_datasheet_TSWV00.pdf.

128. EPPO. 2004. Normes OEPP/EPPO Standards. Diagnostic protocols for regulated pests. PM 7/34. Bulletin OEPP/EPPO Bulletin, 34:271 -279.

129. EPPO. 2020. EPPO Global Database. [En línea]. Consultado 20/5/2020. Disponible en https://gd.eppo.int.

130. ESTEVEZ DE JENSEN, C.; BADILLO-VARGAS, I.E.; FRANZ, G.; MELLINGER, H.C.; TURECHEK, W.W.; HUTTON, S.F.; FUNDERBURK, J.E.; NAIDU; R.A.; ADKINS, S. 2017. First report of tomato chlorotic spot virus in the non-solanaceous weeds erect spinderling (Boerhavia erecta), Asian spider flower (Cleome viscosa) and sweet chili pepper (Capsicum chinense) in Puerto Rico. Plant Health Progress, 18:17-18

131. FELDMAN, J. M.; GRACIA, 0. 1985. Tomato spotted wilt in tomato in Salta and Jujuy IDIA, 433/436:88-89.

132. FELDHOFF, A.; KIKKERT, M.; KORMELINK, R.; KRCZAL. G.; GOLDBACH, R.; PETERS, D. 1997. Serological comparison of tospoviruses with polyclonal antibodies produced against the main structural proteins of tomato spotted wilt virus. Archives of Virology, 142:781-793 
133. FERMIN, G. 2018. Virion Structure, Genome Organization, and Taxonomy of Viruses. En: Viruses: Molecular biology, host interactions, and applications to biotechnology. Eds. Tennant, P.; Fermin, G. and Foster, J.E. Academic Press. p 17-54

134. FERRAND, L.; ALMEIDA, M.M.S.; ORILIO, A.F.; DAL BO, E.; RESENDE, R.0.; GARCIA, M.L. 2019. Biological and molecular characterization of Tomato spotted wilt virus (TSWV) resistance-breaking isolates from Argentina. Plant Pathology, 68(9):1587-1601

135. FINETTI-SIALER, M.M.; LANAVE, C.; PADULA, M.; VOVLAS, C.; GALLITELLI, D. 2002. Occurrence of two distinct tomato spotted wilt virus subgroups in Southern Italy. Journal of Plant Pathology, 84:145-152

136. FLETCHER, J.D. 2001. New hosts of Alfalfa mosaic virus, Cucumber mosaic virus, Potato virus $\mathrm{Y}$, Soybean dwarf virus, and tomato spotted wilt virus in New Zealand. New Zealand Journal of Crop and Horticultural Science, 29 (3):213-217

137. FRANCKI, R.I.B.; FAUQUET, C.M.; KNUDSON, D.L.; BROWN, F. 1991. Classification and nomenclature of viruses: Fifth report of the International Committee on Taxonomy of Viruses. Archives of Virology (Suppl.), 2: 1-450

138. FUNDERBURK, J.; STAVISKY, J.; OLSEN, S. 2000. Predation of Frankliniella occidentalis (Thysanoptera: Thripidae) in field peppers by Orius insidiosus (Hemiptera: Anthocoridae). Environmental Entomology, 29:376-382

139. FUNDERBURK, J. 2009. Management of the western flower thrips (Thysanoptera: Thripidae) in fruiting vegetables. Florida Entomologist, 92: 1-6

140. GARDLAND, S.; SHARMAN, M.; PERSLEY, D.M.; MCGRATH, D. 2005. The development of an improved PCR-based marker system for Sw-5, an important TSWV resistance gene of tomato. Australian Journal of Agricultural Research, 56(3):285-289

141. GAUM, W.G.; GILIOMEE, J.H.; PRINGLE, K.L. 1994. Life history and life tables of western flower thrips, Frankliniella occidentalis (Thysanoptera: Thripidae), on English cucumbers. Bulletin of Entomological Research, 84(2):219-224

142. GENDA, Y; TSUDA, S.; NUNOMURA, 0.; ITO, T. 2008. Development of an assay system using thrips-mediated inoculation to evaluate resistance of Capsicum spp. to Tomato spotted wilt virus. Journal of General Plant Pathology, 74:171-175

143. GERMAN, T.L.; ULLMAN, D.E.; MOYER, J.W. 1992. Tospoviruses: diagnosis, molecular biology, phylogeny and vector relationships. Annual Review of Phytopathology, 30:315348

144. GIAMBIASI, M; GONZÁLEZ-ARCOS, M.; ARRUABARRENA, A. 2019. Utilización de marcadores moleculares asociados a genes de resistencia en el mejoramiento genético de tomate. En: INIA (Instituto Nacional de Investigación Agropecuaria); Programa Nacional Producción Hortícola. Resúmenes. Jornada Mejoramiento Genético de Hortalizas: Ciencia y Tecnología para la producción y el consumidor, 2019, Salto, Uruguay. Trabajos de investigación relacionados al proyecto. Salto (UY): INIA, 2019. p. 35. 
145. GITAITIS, R. D.; DOWLER, C. C.; CHALFANT, R. B. 1998. Epidemiology of tomato spotted wilt in pepper and tomato in Southern Georgia. Plant Disease, 82:752-756

146. GOLDBACH, R.; PETERS, D. 1996. Molecular and Biological Aspects of Tospoviruses. En: Elliott R.M. (eds) The Bunyaviridae. The Viruses. Springer, Boston, MA. p 129-157

147. GOLDBACH, R.W.; KUO, G. 1996. Introduction: proceedings of the international symposium on tospovirus and thrips of floral and vegetable crops. Acta Horticulturae, 431:21-26

148. GONZÁLEZ, M. , RUBIO, L. , ARRUABARRENA, A. , MAESO, D. 2014. Factores que afectan la incidencia del virus de la peste negra en cultivos de pimiento del norte del país. En: CONGRESO NACIONAL DE HORTI-FRUTICULTURA $113^{\circ}, 2014$, Montevideo, Uruguay). Trabajos presentados. p 101

149. GONSALVES, D.; TRUJILLO, E.E. 1986. Tomato spotted wilt virus in papaya and detection of the virus by ELISA. Plant Disease, 70:501-506

150. GORDILLO, L.F.; STEVENS, M.R.; MILLAR, M.A.; GEARY, B. 2008. Screening to Lycopersicon peruvianum collections for resistance to Tomato spotted wilt virus. Plant Disease, 92:694-704

151. GRACIA, 0.; FELDMAN, J. M. 1989. First report of Tomato spotted wilt virus on celery and three weed species in Argentina. Plant Disease, 73 (10): 859

152. GRACIA, 0.; DE BORBON, C.M.; GRANVAL DE MILLAN, N.; CUESTA, G.V. 1999. Occurrence of different tospoviruses in vegetable crops in Argentina. Journal of Phytopathology, 147(4):193-256

153. GRANVAL DE MILLÁN, N.; GRACIA, 0. 1999. El género tospovirus y su importancia en la horticultura. Avances en horticultura, 4 (1):1-23

154. GREENOUGH, D.R.; BLACK, L.L.; BOND, W.P. 1990. Aluminum-surfaced mulch: An approach to the control of Tomato spotted wilt virus in solanaceous crops. Plant Disease, 74:805-808

155. GROVES, R. L.; WALGENBACH, J. F.; MOYER, J. W.; KENNEDY, G. G. 2001. Overwintering of Frankiniella fusca (Thysanoptera: Thripidae) on winter annual weeds infected with Tomato spotted wilt virus and patterns of virus movement between susceptible weed hosts. Phytopathology, 91:891-899

156. GROVES, R.L.; SORENSON, C.; WALGENBACH, J.F.; KENNEDY, G.G. 2001. Effects of imidacloprid on transmission of Tomato spotted wilt tospovirus to pepper, tomato and tobacco by Frankliniella fusca Hinds (Thysanoptera: Thripidae). Crop Protection, $20: 439-445$

157. GROVES, R. L.; WALGENBACH, J. F.; MOYER, J. W.; KENNEDY, G. G. 2002. The role of weed hosts and tobacco thrips, Frankliniella fusca, in the epidemiology of Tomato spotted wilt virus. Plant Disease, 86:573-582 
158. GROVES, R.L.; WALGENBACH, J.F.; MOYER, J.W.; KENNEDY, G.G. 2003. Seasonal dispersal patterns of Frankliniella fusca (Thysanoptera: Thripidae) and tomato spotted wilt virus occurrence in central and eastern North Carolina. Journal of Economical Entomology, 96:1-11

159. HALLWASS, M.; DE OLIVEIRA, A.S.; DIANESE, E.D.C.; LOHUIS, D.; BOITEAUX, L.S.; INOUE-NAGATA, A.K.; RESENDE, R.0.; KORMELINK, R. 2014. The tomato spotted wilt virus cell-to-cell movement protein (NSM) triggers a hypersensitive response in $S w-5$ -containing resistant tomato lines and in Nicotiana benthamiana transformed with the functional Sw-5b resistance gene copy. Molecular Plant Pathology, 15(9):871-880

160. HAMILTON, J.G.C.; HALL, D.; KIRK, W.D.J. 2005. Identification of a male-produced aggregation pheromone in the western flower thrips, Franliniella occidentalis. Journal of Chemical Ecology, 31:1369-1379

161. HANSSEN, I.M.; LAPIDOT, M.; THOMMA, B.P. 2010. Emerging viral diseases of tomato crops. Molecular Plant Microbe Interactions, 23:539-548

162. HERBERT, D.A.; MALONE, S.; AREF, S.; BRANDENBURG, R.L.; JORDAN, D.L.; ROYALS, B.M.; JOHNSON, P.D. 2007. Role of insecticides in reducing thrips injury to plants and incidence of tomato spotted wilt virus in Virginia market-type peanut. Journal of Economic Entomology, 100(4):1241-1247

163. HERRERO, S.; CULBREATH, A. K.; CSINOS, A. S.; PAPPU, H. R.; RUFTY, R. B.; DAUB, M. E. 2000. Nucleocapsid gene-mediated transgenic resistance provides protection against tomato spotted wilt virus epidemics in the field. Phytopathology, 90:139-147

164. HEYLER, N.L. 1993. Verticillium lecanii for the control of aphids and thrips on cucumber. IOBC/WPRS Bulletin, 16(2): 63-66

165. HOBBS, H.A.; BLACK, L.L.; STORY, R.N.; VALVERDE, R.A.; BOND, W.P.; GRATTI, J.M.; SCHAEFFER, D.0.; JOHNSON R.R. 1993. Transmission of Tomato spotted wilt virus from pepper and three weed hosts by Frankliniella fusca. Plant Disease, 77:797-799

166. HOFFMANN, K.; QIU, W.P.; MOYER, J.W. 2001. Overcoming Host- and Pathogen-Mediated Resistance in Tomato and Tobacco Maps to the M RNA of Tomato spotted wilt virus. Molecular Plant Microbe Interactions, 14 (2): 242-249

167. HOULE, J.N.; KENNEDY, G.G. 2017. Tomato spotted wilt virus can infect resistant tomato when western flower thrips inoculate blossoms. Plant Disease, 101(9):1666-1670

168. HUGENOT, C.; VAN DEN DOBBELSTEEN, G.; DE HAAN, P.; WAGEMAKERS, C.A.M.; DROST, G.A.; OSTERHAUS, A.D.M.E.; PETERS, D. 1990. Detection of tomato spotted wilt virus using monoclonal antibodies and riboprobes. Archives of Virology, 110:4762

169. HURT, C.A.; BRANDENBURG, R.L.; JORDAN, D.L.; KENNEDY, G.G.; BAILEY, J.E. 2005. Management of Spotted Wilt Vectored by Frankliniella fusca (Thysanoptera: Thripidae) in Virginia Market-Type Peanut. Journal of Economical Entomology, 98(5):1435-1440 
170. ICTV. 2019. International Committee on Taxonomy of Viruses. ICTV Master Species List 2019 v2. Checklist dataset. [En línea] Consultado el 27/5/2020. Disponible en https://www.gbif.org/species/search?q=Orthotospovirus\&rank=SPECIES\&status=ACCEPTED.

171. IE, T.S. 1970. Tomato spotted wilt virus, CMI/AAB Descriptions of Plant Viruses Nº 39.

172. IE, T. S. 1982. A sap transmissible, defective form of tomato spotted wilt virus. Journal of General Virology, 59:387-391.

173. INOUE, T.; SAKURAI, T. 2006. Infection of tomato spotted wilt virus (TSWV) shortens the life span of thelytokous Thrips tabaci (Thysanoptera: Thripidae). Applied Entomology and Zoolology, 41 (2): 239-246

174. INOUE, T.; SAKURAI, T. 2007. The phylogeny of thrips (Thysanoptera: Thripidae) based on partial sequences of cytochrome oxidase I, 28S ribosomal DNA and elongation factor- $1 \mathrm{a}$ and the association with vector competence of tospoviruses. Applied Entomology and Zoology, 42 (1): 71-81

175. IPPC. 2017. International Plant Protection Convention. Diagnostic protocols for regulated pests DP 24: Tomato spotted wilt virus, Impatiens necrotic spot virus and Watermelon silver mottle virus. $16 \mathrm{p}$.

176. JACOBSON, A.L.; KENNEDY, G.G. 2013. Specific insect-virus interactions are responsible for variation in competency of different Thrips tabaci isolines to transmit different Tomato spotted wilt virus isolates. PLoS ONE, 8(1): e54567.

doi:10.1371/journal.pone.0054567

177. JACOBSON, A.L.; BOOTH, W.; VARGO, E.L.; KENNEDY, G.G. 2013. Thrips tabaci population genetic structure and polyploidy in relation to competency as a vector of Tomato spotted wilt virus. PLoSONE,8(1):e54484. doi:10.1371/journal.pone.0054484

178. JAHN, M.; PARAN, I.; HOFFMANN, K.; RADWANSKI, E.; LIVINGSTONE, K.; GRUBE, R.; AFTERGOOT, E.; LAPIDOT, M.; MOYER, J. 2000. Genetic mapping of the Tsw locus for resistance to the Tospovirus tomato spotted wilt virus in Capsicum spp. and its relationship to the $S_{w}-5$ gene for resistance to the same pathogen in tomato. Molecular Plant Microbe Interactions, $13(6)$ : 673-682

179. JEGER, M. J.; VAN DEN BOSCH, F.; MCROBERTS, N. 2015. Modelling transmission characteristics and epidemic development of the tospovirus-thrips interaction. Arthropod-Plant Interactions, 9:107-120

180. JOHNSON, R.R.; BLACK, L.L.; HOBBS, H.A.; VALVERDE, R.A.; STORY, R.N.; BOND, W.P. 1995. Association of Frankliniella fusca and three winter weeds with Tomato spotted wilt virus in Louisiana. Plant Disease, 79:572-576

181. JONES, D.R. 2004. Using epidemiological information to develop effective integrated virus disease management strategies. Virus Research, 100:5-30

182. JONES, D.R. 2005. Plant viruses transmitted by thrips. European Journal of Plant Pathology, 113:119-157 
183. JOOST, H.; RILEY, D. 2005. Imidacloprid effects on probing and settling behavior of Frankliniella fusca and Frankliniella occidentalis (Thysanoptera: Thripidae) in tomato. Journal of Economical Entomology, 98:1622-1629

184. JOOST, P.H.; RILEY, D.G. 2008. Tomato plant and leaf age effects on the probing and settling behavior of Frankliniella fusca and Frankliniella occidentalis (Thysanoptera: Thripidae). Environmental Entomology, 37:213-223

185. JORDA, C.; FONT, I.; LAZARO, A.; JUAREZ, M.; ORTEGA, A.; LACASA, A. 2000. New natural hosts of Tomato spotted wilt virus. Plant disease, 84 (4):489

186. JULIATTI F.C.; MALUF W.R. 1995. Controle genético da resistência do tomateiro a um isolado de tospovirus (TSVW): análise de plantas individuais. Fitopatologia Brasileira, 20:39-47

187. KAHN, N.D.; WALGENBACH, J.F.; KENNEDY, G.G. 2005. Summer Weeds as Hosts for Frankliniella occidentalis and Frankliniella fusca (Thysanoptera: Thripidae) and as Reservoirs for Tomato Spotted Wilt Tospovirus in North Carolina. Journal of Economical Entomology, 98(6): 1810-1815

188. KIKKERT, M.; VERSCHOOR, A.D.; KORMELINK, R.; PETERS, D.; GOLDBACH, R.W. 2001. Tomato spotted wilt virus glycoproteins exhibit trafficking and localization signals that are functional in mammalian cells. Journal of Virology, 75:1004-1012

189. KIL, E.J.; CHUNG; Y.J.; CHOI, H.S.; LEE, S.; KIM, C.S. 2020. Life Cycle-Based Host Range Analysis for tomato spotted wilt virus in Korea. Plant Pathololgy Journal, 36(1): 67-75

190. KOCH DE BROTOS, L.; BOASSO, C. 1955. Lista de las enfermedades de los vegetales en el Uruguay. Laboratorio de Fisiología y Patología Vegetal. Publicación No. 106. Dirección. de Agronomía. Ministerio de Ganadería y Agricultura. 65 p.

191. KOCH DE BROTOS, L.; BOASSO, C. 1981. Enfermedades de las plantas, hongos superiores y saprofitas en el Uruguay. Montevideo, Departamento de Comunicaciones, Dirección de Sanidad Vegetal, M.A.P. 140 p.

192. KOCH DE BROTOS, L. 1985. Enfermedades y plagas del tomate Montevideo (Uruguay): MGAP. 29 p.

193. KORMELINK, R.; DE HAAN, P.; PETERS, D.; GOLDBACH, R. 1991. Tomato spotted wilt virus: A Bunyavirus invading the Plant Kingdom. En: Plant Molecular Biology 2. Eds. R.G. Herrmann; B. Larkins, Plenum Press, New York, 1991. p 49-56.

194. KORMELINK, R.; DE HAAN, P.; MEURS, C.; PETERS, D.; GOLDBACH, R. 1992. The nucleotide sequence of the M RNA segment of tomato spotted wilt virus. A plant-infecting bunyavirus with two ambisense RNA segments. Journal of General Virology, 73: 27952804

195. KORMELINK, R.; STORMS, M.; VAN LENT, J.; PETERS, D.; GOLDBACH, R. 1994. EXpression and subcellular location of the NSm protein of tomato spotted wilt virus (TSWV), a putative viral movement protein. Virology, 200:56-65 
196. KORMELINK, R. 2005. Tomato spotted wilt virus. Descriptions of plant viruses. [En línea]. Consultado 29/5/2020. Disponible en http://www.dpvweb.net.

197. KUMAR, N.K.K.; ULMAN, D.E.; CHO, J.J. 1993. Evaluation of Lycopersicon germplasm for tomato spotted wilt tospovirus resistance by mechanical and thrips transmission. Plant Disease, 77:938-941

198. KUMAR, N.K.K.; ULLMAN, D.E.; CHO, J.J. 1995. Frankliniella occidentalis (Thysanoptera: Thripidae). Environmental Entomology, 24:513-520

199. LACASA, A.; CONTRERAS, J.; TORRES, J.; GONZÁLEZ, A.; MARTÍNEZ, M.A.C.; GARCÍA, F.; HERNÁNDEZ, A. 1994. Utilización de mallas en el control de Frankliniella occidentalis (Pergande) y el virus del bronceado del tomate (TSWV) en el pimiento en invernadero. Boletín de Sanidad Vegetal, Plagas, 20: 561-580

200. LASA, C. 1982. La peste negra del tomate: una importante virosis. Investigaciones Agronómicas, Centro de Investigaciones Agrícolas "Alberto Boerger" (Uruguay), 3 (1): 73-79

201. LASA, C. 1982b. Evaluación de la tolerancia de cultivares de tomate para consumo fresco, al virus de la peste negra del tomate (TSWV). Identificación de enfermedades a virus en el cultivo de Pimiento. Determinación de razas del virus de la peste negra del Tomate (TSWV), presentes en el país. En: Resultados Experimentales. Control Aplicado: 1981-82. Centro de Investigaciones Agrícolas "Alberto Boerger". Ministerio de Agricultura y Pesca. Informe Especial. 4. 1982.

202. LASA C. 1983. Respuesta de diez cultivares de tomate al virus de la peste negra (TSWV). Investigaciones Agronómicas, Centro de Investigaciones Agrícolas "Alberto Boerger" (Uruguay), 4 (1):6-9

203. LASA, C.; TEZUKA, N. 1980. Aportes a la identificación del TSWV en Uruguay (Sumario) En: REUNIÓN TÉCNICA, FACULTAD DE AGRONOMÍA (3a., 1980, Montevideo, Uruguay). Resúmenes. $114 \mathrm{p}$

204. LASA, C.; ABIKO, K.; TEZUKA, N.; INABA; T; GARCIA; S. 1981. Algunas enfermedades que afectan actualmente los cultivos hortícolas en Uruguay. Investigaciones Agronómicas. Centro de Investigaciones Agrícolas “Alberto Boerger" (Uruguay), 2 (1): 97-100.

205. LASA, C.; NÚÑEZ, S. 1982. Estudio sobre la dinámica poblacional de trips en tomate y su relación con la incidencia del virus de la peste negra del tomate (TSWV) (II) En: Resultados Experimentales. Control Aplicado: 1981-82. Centro de Investigaciones Agrícolas "Alberto Boerger". Ministerio de Agricultura y Pesca. Informe Especial 4.

206. LASA, C.; FRANCIS, M. 1983. Evolución de los estudios en virología en el Uruguay. Investigaciones Agronómicas, Centro de Investigaciones Agrícolas "Alberto Boerger" (Uruguay), 4 (1): 10-14.

207. LATHAM, L.J.; JONES, R.A.C. 1997. Occurrence of tomato spotted wilt tospovirus in native flora, weeds and horticultural crops. Australian Journal of Agricultural Research, 48:359-369 
208. LATHAM, L. J.; JONES, R. A. C. 1998. Selection of resistance breaking strains of tomato spotted wilt tospovirus. Annals of Applied Biology, 133:385-402

209. LAW, M.D.; MOYER, J.W. 1990. A Tomato spotted wilt-like virus with a serologically distinct N protein. Journal of General Virology, 71:933-938

210. LAW, M.D.; SPECK, J.; MOYER, J.W. 1991. Genomic organization of the Impatiens necrotic spot virus M RNA. Phytopathology, 81:1192.

211. LAW, M.D.; SPECK, J.; MOYER, J.W. 1992. The M RNA of impatiens necrotic spot Tospovirus (Bunyaviridae) has an ambisense genomic organization. Virology, 188: 732741

212. LÁZARO, E.; ARMERO, C.; ROSELLÓ, J.; SERRA, J.; MUÑOZ, M.J.; CANET, R.; GALIPIENSO, L.; RUBIO, L. 2019. Comparison of viral infection risk between organic and conventional crops of tomato in Spain. European Journal of Plant Pathology, 155:1145-1154

213. LEWANDOWSKI, D.J.; ADKINS, S. 2005. The tubule-forming NSm protein from Tomato spotted wilt virus complements cell-to-cell and long-distance movement of tobacco mosaic virus hybrids. Virology, 342:26-37

214. LI, W.; LEWANDOWSKI, D.J.; HILF, M.E.; ADKINS, S. 2009. Identification of domains of the Tomato spotted wilt virus NSm protein involved in tubule formation, movement and symptomatology. Virology, 390:110-121

215. LIMA, M. G. A.; MARTINELLI; N.M.; MONTEIRO, R.C. 2000. Ocorrencia de Frankliniella schultzei (Trybom) (Thysanoptera: Thripidae) en plantas daninhas. Planta Daninha, 18 (2):367-372

216. LIU, L.Y.; YE, H.Y.; CHEN, T.H.; CHEN, T.C. 2017. Development of a microarray for simultaneous detection and differentiation of different tospoviruses that are serologically related to Tomato spotted wilt virus. Virology Journal 14:1. [En línea]. Consultado 14/5/2020. Disponible en https://link.springer.com/article/10.1186/s12985-016-0669-1

217. LLAMAS-LLAMAS, M.E.; ZAVALETA-MEJIA, E.; GONZALEZ-HERNANDEZ, B.A.; CERVANTES-DIAZ, L.; SANTIZO-RINCON, J.A.; OCHOA-MARTINEZ, D.L. 1998. Effect of temperature on symptom expression and accumulation of Tomato spotted wilt virus in different host species. Plant Pathology, 47:341-347

218. LÓPEZ LAMBERTINI, P.; WILLIAMS, L.; SHOHARA, K.; DUCASSE, D. 2003. Diagnosis of three Tospovirus species by rapid immunofilter paper assay. Journal of General Plant Pathology, 69 (5):339-341

219. LÓPEZ, C.; ARAMBURU, J.; GALIPIENSO, L.; SOLER, S.; NUEZ, F.; RUBIO, L. 2011. Evolutionary analysis of tomato $S_{W}-5$ resistance breaking isolates of Tomato spotted wilt virus. Journal of General Virology, 92:210-215 
220. LOVATO, F.A.; NAGATA, T.; RESENDE, R.O.; DE ÁVILA, A.C.; INOUE-NAGATA, A.K. 2004. Sequence analysis of the glycoproteins of Tomato chlorotic spot virus and Groundnut ringspot virus and comparison with other Tospoviruses. Virus Genes, 29(3):321-328

221. LOVATO, F.A.; INOUE-NAGATA, A.K.; NAGATA, T.; DE ÁVILA, A.C.; PEREIRA, L.A.; RESENDE, R.0. 2008. The N protein of Tomato spotted wilt virus (TSWV) is associated with the induction of programmed cell death (PCD) in Capsicum chinense plants, a hypersensitive host to TSWV infection. Virus Research, 137(2):245-252

222. LOWRY, V.K.; SMITH, J.R.; MITCHELL, F.L. 1992. Life-Fertility Tables for Frankliniella fusca (Hinds) and F. occidentalis (Pergande) (Thysanoptera: Thripidae) on Peanut. Annals of the Entomological Society of America, 85(6):744-754

223. LUNELLO, P.; MANSILLA, C.; CONCI, V.; PONZ, F. 2004. Ultrasensitive detection of two garlic potyviruses using a realtime fluorescent (TaqMan ${ }^{\circledR}$ ) RT-PCR assay. Journal of Virological Methods, 118:15-21

224. MACHARIA, I.; BACKHOUSE, D.; SKILTON, R.; ATEKA, E.; WU, S.; NJAHIRA, M.; MAINA, S.; HARVEY, J. 2015. Diversity of thrips species and vectors of Tomato spotted wilt virus in tomato production systems in Kenya. Journal of Economical Entomology, $108: 20-28$

225. MACHARIA, I.; BACKHOUSE; D.; WU, S.B.; ATEKA, E.M. 2016. Weed species in tomato production and their role as alternate hosts of Tomato spotted wilt virus and its vector Frankliniella occidentalis. Annals of Applied Biology, 169: 224-235

226. MAES, P. et al. 2019. Taxonomy of the order Bunyavirales: second update 2018. Archives of Virology, 164:927-941

227. MAESO, D.; CARO, G. 1997. La "peste negra": Una virosis de tomate y morrón, ahora también causando daños importantes en lechuga. La Granja Nacional Revista, 5(57):11

228. MAESO, D.; PAULLIER, J.; WALASEK, W.; FERNÁNDEZ, A.; DINI, B. 2005. Estudios epidemiológicos en virosis que afectan tomate en invernadero. En: Resultados experimentales en sanidad del cultivo de tomate. Montevideo: INIA Las Brujas. p 17-45. (Serie Actividades Difusión, 437)

229. MAESO, D.; PAULLIER, J.; WALASEK, W.; FERNÁNDEZ, A. 2007. Estudios epidemiológicos en virosis que afectan tomate en invernadero en la zona sur de Uruguay. En: XI CONGRESO NACIONAL DE LA SOCIEDAD URUGUAYA DE HORTIFRUTICULTURA $111^{\circ}$, 2007, Montevideo, Uruguay). Libro de resúmenes.

230. MAESO, D.; WALASEK, W.; BERNAL, R. 2009. Resultados preliminares a la caracterización serológica de tospovirus. En: Jornada Anual de Resultados Experimentales en el cultivo del tomate. Salto: INIA Salto Grande. p 117-118. (Serie Actividades Difusión, 574) 
231. MAESO, D.; PAULLIER, J.; ARBOLEYA, J.; GONZÁLEZ, P.; FERNÁNDEZ, A.; WALASEK, W. 2013. Seguimiento de peste negra en morrón: Experimentos en la zona sur de Uruguay (2013). En: Jornada de divulgación sobre resultados experimentales en sanidad de tomate y morrón. Montevideo: INIA Las Brujas. p 1-44. (Serie Actividades de Difusión, 723)

232. MAESO, D.; PAULlieR, J.; GONZÁleZ RABELINO, P.; ARBOLEYA, J.; FERNÁNDEZ, A.; WALASEK, W. 2014. Estudio de puntos críticos en el desarrollo de epidemias de "peste negra" (Tospovirus) en morrón en la zona sur de Uruguay (2014). En: CONGRESO NACIONAL DE HORTI-FRUTICULTURA (13, Montevideo. Uruguay), 2014. Trabajos presentados. p 100.

233. MAESO, D.; PAULLIER, J.; GONZÁLEZ, P.; ARBOLEYA, J.; FERNÁNDEZ, A.; WALASEK, W. 2015. Estudio de puntos críticos en el desarrollo de epidemias de peste negra ltospovirus) en morrón en la zona sur de Uruguay. En: JORNADAS DE ENFERMEDADES Y PLAGAS EN CULTIVOS BAJO CUBIERTA. (4ํ․ La Plata, República Argentina). Libro de resúmenes. p 103

234. MAESO, D.; PAULLIER, J.; GONZÁLEZ, P.; ARBOLEYA, J.; FERNÁNDEZ, A.; WALASEK, W. 2015b. Seguimiento de peste negra en morrón. Experimentos en la zona sur de Uruguay. Ciclo 2013-2014. En: Jornada de divulgación de resultados experimentales en sanidad de tomate y morrón. Montevideo: INIA Las Brujas. (Serie de Actividades de Difusión,756) p 92-107

235. MAESO, D.; PAULLIER, J.; GONZÁLEZ, P.; ARBOLEYA, J.; FERNÁNDEZ, A.; WALASEK, W. 2015c. Study of critical points that lead of spotted wilt (Tospovirus) outbreaks in sweet pepper in Uruguay. En: INTERNATIONAL PLANT PROTECTION CONGRESS $11^{\circ}$, 2015, Berlín, Alemania). Abstracts from the XVIII. International Plant Protection Congress. p 349

236. MAHARIJAYA, A.; VOSMAN, B.; STEENHUIS-BROERS, G.; HARPENAS, A.; PURWITO, A.; VISSER, R.G.F.; VOORRIPS, R.E. 2011 Screening of pepper accessions for resistance against two thrips species (Frankliniella occidentalis and Thrips parvispinus). Euphytica, $177: 401-410$

237. MANDAL, B.; PAPPU, H. R.; CULBREATH, A. K. 2001. Factors affecting mechanical transmission of Tomato spotted wilt virus to peanut (Arachis hypogaea). Plant Disease, $85: 1259-1263$

238. MANDAL, B.; PAPPU, H.R.; CULBREATH, A.K.; HOLBROOK, C.C.; GORBET, D.W.; TODD, J.W. 2002. Differential response of selected peanut (Arachis hypogaea) genotypes to mechanical inoculation by Tomato spotted wilt virus. Plant Disease, 86:939-944

239. MANDAL, B.; CSINOS, A.S.; MARTINEZ-OCHOA, N.; PAPPU, H.R. 2008. A rapid and efficient inoculation method for Tomato spotted wilt tospovirus. Journal of Virological Methods, 149:195-198

240. MANIANIA, N.K.; EKESI, S.; LÖHR, B.; MWANGI, F. 2001. Prospects for biological control of the western flower thrips, Frankliniella occidentalis, with the entomopathogenic fungus, Metarhizium anisopliae, on chrysanthemum. Mycopathologia, 155: 229-235 
241. MARGARIA, P.; CIUFFO, M.; TURINA, M. 2004. Resistance breaking strain of Tomato spotted wilt virus (Tospovirus; Bunyaviridae) on resistant pepper cultivars in Almería, Spain. Plant Pathology, 53:795

242. MARGARIA, P.; CIUfFO, M.; PACIFICO, D.; TURINA, M. 2007. Evidence That the Nonstructural Protein of Tomato spotted wilt virus is the avirulence determinant in the interaction with resistant pepper carrying the Tsw Gene. Molecular Plant Microbe Interactions, 20(5):547-558

243. MARGARIA, P.; BOSCO, L.; VALLINO, M.; CIUfFO, M.; MAUTINO, G.C.; TAVELLA, L.; TURINA, M. 2014. The NSs Protein of Tomato spotted wilt virus Is Required for Persistent Infection and Transmission by Frankliniella occidentalis. Journal of Virology, 88(10):5788-5802

244. MARIS, P. C.; JOOSTEN, N. N.; PETERS, D.; GOLDBACH, R. W. 2003. Thrips resistance in pepper and its consequences for the acquisition and inoculation of Tomato spotted wilt virus by the western flower thrips. Phytopathology, 93:96-101

245. MARIS, P. C.; JOOSTEN, N. N.; GOLDBACH, R. W.; PETERS, D. 2003b. Restricted spread of Tomato spotted wilt virus in thrips-resistant pepper. Phytopathology, 93:1223-1227

246. MARIS, P.C.; JOOSTEN, N.N.; GOLDBACH, R.W.; PETERS, D. 2004. Tomato spotted wilt virus infection improves host suitability for its vector Frankliniella occidentalis. Phytopathology, 94:706-711

247. MARTÍNEZ, R.T.; DE ALMEIDA, M.M.S.; RODRIGUEZ, R.; CAYETANO, X.; DE OLIVEIRA, A.S.; SILVA, J.M.F.; MELO, F.L.; RESENDE, R.0. 2019. Analyses of orthotospovirus populations and dispersion under different environmental conditions in Brazil and in the Dominican Republic. Tropical Plant Pathology, 44:511-518

248. MATEUS, C.; PEQUITO, A.; TEIXEIRA, S.; QUEIRÓS, R.; GODINHO, M.C.; FIGUEIREDO, E.; AMARO, F.; LACASA, A.; MEXIA, A. 2012. Development of a Tomato spotted wilt virus (TSWV) risk evaluation methodology for a processing tomato region. Spanish Journal of Agricultural Research, 10(1): 191-197

249. MATTESON, N.; TERRY, I.; ASCOLI-CHRISTENSEN, A.; GILBERT, C. 1992. Spectral efficiency of the western flower thrips, Frankliniella occidentalis. Journal of Insect Physiology, 38(6):453-459

250. MATTHEWS, R.E.F. 1982. Classification and nomenclature of viruses. Intervirology, 17:1-199

251. MCDONALD, J.R.; BALE, J.S.; WALTERS, K.F. 1998. Effect of temperature on development of the western flower thrips, Frankliniella occidentalis (Thysanoptera: Thripidae). European Journal of Entomology, 95:301-306

252. MCPHERSON, R.M.; BESHEAR, R.J.; CULBREATH, A.K. 1992. Seasonal abundance of thrips (Thysanoptera: Suborders Terebrantia and Tubulifera) in Georgia flue-cured tobacco and impact of management practices on the incidence of tomato spotted wilt virus. Journal of Entomological Science, 27:257-268 
253. MCPHERSON, R.M.; PAPPU, H.R.; JONES, D.C. 1999. Occurrence of five thrips species on flue-cured tobacco and impact on spotted wilt disease incidence in Georgia. Plant Disease, 83:765-767

254. MCPHERSON, R.M.; STEPHENSON, M.G.; LAHUE, S.S.; MULLIS, S.W. 2005. Impact of early-season thrips management on reducing the risks of spotted wilt virus and suppressing aphid populations in flue-cured tobacco. Journal of Economic Entomology, 98(1): 129-134

255. MENG, J.R.; LIU, P.P.; ZOU, C.W.; WANG, Z.Q.; LIAO, Y.M.; CAI, J.H.; QIN, B.X.; CHEN, B.S. 2013. First report of a tospovirus in mulberry. Plant Disease, 97:1001

256. METERLIK, J.; GÖTZOVA, B.; MOKRÁ, V. 1996. Epidemiological aspects of Tomato spotted wilt virus infection in the Czech Republic. Acta Horticulturae, 432:368-375

257. MILNE, R.G.; FRANCKI, R.I.B. 1984. Should Tomato spotted wilt virus be considered as a possible member of the family Bunyaviridae? Intervirology, 22: 72-76

258. MITTER, N.; ZHAI, Y.; BAI, A.X.; CHUA, K.; EID, S.; CONSTANTIN, M.; MITCHELL, R.; PAPPU, H.R. 2016. Evaluation and identification of candidate genes for artificial micro RNA-mediated resistance to tomato spotted wilt virus. Virus Research, 211:151-158

259. MOMOL, M.T.; OLSON, S.M.; FUNDERBURK, J.E.; STAVISKY, J.; MAROIS, J.J. 2004. Integrated management of tomato spotted wilt on field-grown tomatoes. Plant Disease, 88: $882-890$

260. MONSERRAT, A. 2006. Plan de actuación para reducir la presión de virosis y otras fitopatologías, en los cultivos hortícolas de la región de Murcia. Programa de Innovación Tecnológica. Sanidad Vegetal 21.61 p.

261. MORIONES, E.; ARAMBURU, J.; RIUDAVETS, J.; ARNÓ, J.AND LAVIÑA, A. 1998. Effect of plant age at time of infection by tomato spotted wilt tospovirus on the yield of field grown tomato. European Journal of Plant Pathology, 104: 295-300

262. MORITZ, G.; KUMM, S.; MOUND, L. 2004. Tospovirus transmission depends on thrips ontogeny. Virus Research, 100: 143-149

263. MORSELLO, S.C.; KENNEDY, G.G. 2009. Spring temperature and precipitation affect tobacco thrips, Frankliniella fusca, population growth and Tomato spotted wilt virus spread within patches of the winter annual weed Stellaria media. Entomologia Experimentalis et Applicata, 130: 138-148

264. MORSELLO, S.C.; BEAUDOIN, A.L.P.; GROVES, R.L.; NAULT, B.A.; KENNEDY, G.G. 2010. The influence of temperature and precipitation on spring dispersal of Frankliniella fusca changes as the season progresses. Entomologia Experimentalis et Applicata, 134: $260-271$

265. MORTIMER-JONES, S.M.; JONES, M.G.; JONES, R.A.; THOMSON, G.; DWYER, G.I. 2009. A single tube, quantitative real-time RT-PCR assay that detects four potato viruses simultaneously. Journal of Virolological Methods, 161:289-296 
266. MOUDEN, S.; SARMIENTO, K.F.; KLINKHAMER, P.G.L.; LEISS, K.A. 2017. Integrated pest management in western flower thrips: past, present and future. Pest Management Science, 73: 813-822

267. MOUND, L.A. 1996. The Thysanoptera vector species of tospoviruses. Acta Horticulturae, 431:299-309

268. MOYER, J.W. 1999. Tospoviruses (Bunyaviridae). En: Encyclopedia of Virology leds. Webster, R. and Granoff, A.J, pp. 1803-1807. Academic Press, London.

269. MOURY, B.; PALLOIX, A.; GEBRE SELASSIE, K.; MARCHOUX, G.1997. Hypersensitive resistance to Tomato spotted wilt virus in three Capsicum chinense accessions is controlled by a single gene and is overcome by virulent strains. Euphytica, 94: 45-52

270. MOURY, B.; SElASSIE, K.G.; MARChOUX, G.; DAUBEZE, A.M.; PALlOIX, A. 1998. High temperature effects on hypersensitive resistance to Tomato spotted wilt tospovirus (TSWV) in pepper (Capsicum chinense Jacq.). European Journal of Plant Pathology, 104: 489-498

271. MUJICA, M.V.; SCATONI, I.; NÚÑEZ, S.; BENTANCOURT, C. 2007. Fluctuación poblacional de trips (Thysanoptera: Thripidae) en Prunus persica (L.) cv. Fantasía en la zona sur de Uruguay. Agrociencia, 11 (2):39-49

272. MUMFORD, R.A.; BARKER, I.; WOOD K.R. 1994. The detection of Tomato spotted wilt virus using polymerase chain reaction. Journal of Virological Methods, 46:303-311

273. MUMFORD, R.A.; BARKER, I.; WOOD, K.R. 1996. The biology of the tospoviruses. Annals of Applied Biolology, 128:159-183

274. MUMFORD, R.A.; BARKER, I.; WOOD, K.R. 1996b. An improved method for the detection of Tospoviruses using the polymerase chain reaction. Journal of Virological Methods, 57:109-l 15

275. MURPHY, F.A.; FAUQUET, C.M.; MAYO, M.A.; JARVIS, A.W.; GHABRIAL, S.A.; SUMMERS, M.D.; MARTELLI, G.P.; BISHOP, D.H.L. Eds. (1995) Sixth Report of The International Committee on Taxonomy of Viruses. Archives of Virology, Springer Verlag, New York.

276. NAGATA, T.; INOUE-NAGATA, A.K.; SMID, H.M.; GOLDBACH, R.; PETERS, D. 1999. Tissue tropism related to vector competence of Frankliniella occidentalis for tomato spotted wilt tospovirus. Journal of General Virology, 80 (2): 507-515

277. NAGATA, T.; INOUE-NAGATA, A. K.; PRINS, M.; GOLDBACH, R.; PETERS, D. 2000. Impeded thrips transmission of defective Tomato spotted wilt virus isolates. Phytopathology, 90:454-459

278. NAGATA, T.; ALMEIDA, A.C.L.; RESENDE, R.0.; DE ÁVILA, AC. 2002. The transmission specificity and efficiency of tospoviruses. En: Marullo, R.; Mound, L.A. (eds). Thrips and Tospoviruses: Proceedings of the 7th International Symposium on Thysanoptera. Canberra, Australian National Insect Collection. pp. 45-46 
279. NAGATA, T.; ALMEIDA, A.C.L.; RESENDE, R. O.; DE ÁVILA, A. C. 2004. The competence of four thrips species to transmit and replicate four tospoviruses. Plant Pathology, $53: 136-140$

280. NERVO, G.; CIRILLO, C.; ACCOTTO, G.P.; VAIRA, A.M. 2003. Characterization of two tomato lines highly resistant to Tomato spotted wilt virus following transformation with the viral nucleoproteine. Journal of Plant Pathology, 85 (3):139-144

281. NISCHWITZ, C.; CSINOS, A. S.; MULLIS, S. W.; HICKMAN, L. L.; STEVENSON, K. L.; GITAITIS, R. D. 2008. Effect of transplant age, tobacco cultivar, acibenzolar-S-methyl, and imidacloprid on tomato spotted wilt infection in flue-cured tobacco. Plant Disease, 92:1524-1528

282. NORRIS, D. 1946. The strain complex and symptom development of tomato spotted wilt virus. Bulletin of Australian Council for Scientific and Industrial Research Bulletin 202. $51 \mathrm{p}$.

283. NORTHFIELD, T.D.; PAINI, D.R.; FUNDERBURK, J.E.; REITZ, S.R. 2008. Annual cycles of Frankliniella spp. (Thysanoptera: Thripidae) thrips abundance on North Florida uncultivated reproductive hosts: Predicting possible sources of pest outbreaks. Annals of the Entomological Society of America, 101(4):769-778

284. NUÑEZ, S.; CARBONELL, J.; BRIOZZO, J. 1983. Comportamiento de poblaciones de trips (Thysanoptera: Thrypidae) asociados al cultivo de cebolla y tomate. Investigaciones Agronómicas, Centro de Investigaciones Agrícolas “Alberto Boerger" (Uruguay), 4: $62-64$.

285. OGADA, P.A.; MAISS, E.; POEHLING, H.M. 2013. Influence of Tomato spotted wilt virus on performance and behavior of western flower thrips (Frankliniella occidentalis). Journal of Applied Entomology, 137: 488-498

286. OGADA, P.A.; POEHLING, H.M. 2015. Sex-specific influences of Frankliniella occidentalis (Western Flower Thrips) in the transmission of Tomato spotted wilt virus (Tospovirus). Journal of Plant Diseases and Protection, 122 (5/6):264-274

287. OGADA, P.A; DEBENER, T.; POEHLING, H.M. 2016. Inheritance genetics of the trait vector competence in Frankliniella occidentalis (Western flower thrips) in the transmission of Tomato spotted wilt virus. Ecology and Evolution, 6: 7911-7920

288. OKAZAKI, S.; OKUDA, M.; KOMI, K.; YOSHIMATSU, H.; IWANAMI, T. 2007. Overwintering viruliferous Frankliniella occidentalis (Thysanoptera: Thripidae) as an infection source of Tomato spotted wilt virus in green pepper fields. Plant Disease, 91:842-846

289. OKAZAKI, S.; OKUDA, M.; SAKURAI, T. 2009. Evaluation of Weed Species as Tomato spotted wilt virus (Bunyaviridae: Tospovirus) Acquisition Sources for Frankliniella occidentalis (Pergande) (Thysanoptera: Thripidae). Japanese Journal of Applied Entomology and Zoology, 53(4):181-184 
290. OLATINWO, R.0.; PAZ, J.0.; BROWN, S.L.; KEMERAIT JR.; R.C.; CULBREATH, A.K.; BEASLEY JR.; J.P.; HOOGENBOOM, G. 2008. A predictive model for spotted wilt epidemics in peanut based on local weather conditions and the Tomato spotted wilt virus risk index. Phytopathology, 98:1066-1074

291. OLATINWO, R.0.; PAZ, J.0.; BROWN, S.L.; KEMERAIT JR.; R.C.; CULBREATH, A.K.; HOOGENBOOM, G. 2009. Impact of early spring weather factors on the risk of tomato spotted wilt in peanut. Plant Disease, 93:783-788

292. OLATINWO, R.0.; PAZ, J.0.; KEMERAIT JR.; R.C.; CULBREATH, A.K.; HOOGENBOOM, G. 2010. El Niño-Southern Oscillation (ENSO): impact on tomato spotted wilt intensity in peanut and the implication on yield. Crop Protection, 29:448-453

293. OLAYA, C.; FLETCHER, S.J.; ZHAI, Y.; PETERS, J.; MARGARIA, P.; WINTER, S.; MITTER, N.; PAPPU, H.R. 2020. The Tomato spotted wilt virus (TSWV) Genome is Differentially Targeted in TSWV-Infected Tomato (Solanum lycopersicum) with or without Sw-5 Gene. Viruses, 12, 363

294. OLIVER, J.E.; WHITFIELD, A.E. 2016. The Genus Tospovirus: Emerging Bunyaviruses that threaten food security. Annual Review of Virology, 3:101-124

295. ORMEÑO, J.; SEPÚLVEDA, P. 2005. Presencia de diferentes virus del pimiento (Capsicum annuum L.) en especies de malezas asociadas al cultivo. Agricultura Técnica (Chile), 65(4):343-355

296. PADMANABHAN, C.; MA, Q.; SHEKASTEBAND, R.; STEWART, K.S.; HUTTON, S.F.; SCOTT, J.W.; FEI, Z.F.; LING, K.S. 2019. Comprehensive transcriptome analysis and functional characterization of PR-5 for its involvement in tomato Sw-7 resistance to tomato spotted wilt tospovirus. Scientific Reports (2019), 9:7673

https://doi.org/10.1038/s41598-019-44100-x

297. PANTHEE, D.P. 2012. A reexamination of molecular markers for use in marker-assisted breeding in tomato. Euphytica, 184:165-179

298. PAPPU, H.; PAPPU, S.; JAIN, R.; BERTRAND, P.; CULBREATH, A.; MCPHERSON, R.; CSINOS, A. 1998. Sequence characteristics of natural populations of tomato spotted wilt tospovirus infected flue-cured tobacco in Georgia. Virus Genes, 17:169-177

299. PAPPU, H.; CSINOS, A.; MCPHERSON, R.; JONES, D.; STEPHENSON, M. 2000. Effect of acibenzolar- S-methyl and imidacloprid on suppression of Tomato spotted wilt tospovirus in flue-cured tobacco. Crop Protection, 19:349-354

300. PAPPU, H.R.; JONES, R.A.; JAIN, R.K. 2009. Global status of tospovirus epidemics in diverse cropping systems: successes achieved and challenges ahead. Virus Research, 141:219-236

301. PARK, Y.G.; LEE, J.H. 2020. Life history characteristics of the western flower thrips, Frankliniella occidentalis (Pergande) (Thysanoptera: Thripidae), under fluctuating conditions of temperature or relative humidity. Journal of Asia-Pacific Entomology, 23:606-611 
302. PARRELLA, G.; GOGNALONS, P.; GEBRE-SELASSIÈ, K.; VOVLAS, C.; MARCHOUX, G. 2003. An update of the host range of tomato spotted wilt virus. Journal of Plant Pathology, 85:227-264

303. PEIRÓ, A.; CAÑIZARES, M.C.; RUBIO, L.; LÓPEZ, C.; MORIONES, E.; ARAMBURU, J.; SÁNCHEZ-NAVARRO, J. 2014. The movement protein (NSm) of Tomato spotted wilt virus is the avirulence determinant in the tomato $S_{w}-5$ gene-based resistance. Molecular Plant Pathology, 15(8):802-813

304. PERSLEY, D.M.; THOMAS, J.E.; SHARMAN, M. 2006. Tospoviruses-an Australian perspective. Australasian Plant Pathology, 35, 161-180

305. PETERS, D.; DE ÁVILA, A.C.; KITAYIMA, E.W.; RESENDE, R. DE 0.; DE HAAN, P.; GOLDBACH, R. 1991. An overview of tomato spotted wilt virus. En: H.T. Hsu and R.H. Lawson (Eds). Virus-thrips-plant Interactions of TSWV, Proceeding of USDA workshop, Beltsville, Maryland, April 1990. National Technology Information Service, Springbeld, USA, pp. 1-14.

306. PETERS, D.; WIJKAMP, I.; VAN DE WETERING, F.; GOLDBACH, R. 1996. Vector relations in the transmission and epidemiology of tospoviruses. Acta Horticulturae, 431:29-43

307. PETERS, D. 1998. An updated list of plant species susceptible to Tospoviruses. En: Peters, D.; Goldbach, R. (Eds.), Recent Progress in Tospovirus and Thrips Research. Wageningen, The Netherlands, pp. 107-110.

308. PETERS, D. 2003. A threat to the intensive agriculture in the tropics. En: Virus and virus-like diseases in major crops in developing countries. Eds. Loebenstein, G. and Thottapilly, G. Kluwer Academic Publishers, Dordrecht, The Netherlands, 719-742.

309. POUDEL, B.; ABDALLA, O.A.; LIU, Q.; WANG, Q.; MCAVOY, E.; SEAL, D.; LING, K.S.; MCGRATH, M.; ZHANG, S. 2019. Field distribution and disease incidence of Tomato chlorotic spot virus, an emerging virus threatening tomato production in South Florida. Tropical plant pathology, 44:430-437

310. POZZER, L.; BEZERRA, I.C.; KORMELINK, R.; PRINS, M.; PETERS, D.; RESENDE, R.0.; DE ÁVILA, A.C. 1999. Characterization of a distinct tospovirus isolate of Iris yellow spot virus associated with a disease in onion fields in Brazil. Plant Disease, 83:345-350

311. PRINS, M.; GOLDBACH, R. 1998. The emerging problem of tospovirus infection and nonconventional methods of control. Trends in Microbiology, 6:31-35

312. QIU, W.P.; GESKE, S.M.; HICKEY, C.M.; MOYER, J.W. 1998. Tomato spotted wilt Tospovirus genome reassortment and genome segment-specific adaptation. Virology, 244:186-194

313. RAID, R.N.; ALLINGHAM, J.R.; FUNDERBURK, J.E.; STARLINSKY, T.; HUTTON, S.F.; TURECHEK, W.W.; ADKINS, S. 2017. First report of Tomato chlorotic spot virus in sweet basil (Ocimum basilicum) and purslane (Portulaca oleracea) in Florida. Plant Health Progress, 18:126-128 
314. RAMESH, S.V.; WILliamS, S.; KAPPAGANTU, M.; MITTER, N.; PAPPU, H.R. 2017. Transcriptome-wide identification of host genes targeted by tomato spotted wilt virusderived small interfering RNAs. Virus Research, 238:13-23

315. RAMKAT, R.C.; WANGAI, A.W.; OUMA, J.P.; RAPANDO, P.N.; LELGUT, D.K. 2008. Cropping system influences Tomato spotted wilt virus disease development, thrips population and yield of tomato (Lycopersicon esculentum). Annals of Applied Biology, 153: 373-380

316. REITZ, S.R.; YEARBY, E.L.; FUNDERBURK, J.E.; STAVISKY, J.; MOMOL, M.T.; OLSON, S.M. 2003. Integrated management tactics for Frankliniella thrips (Thysanoptera: Thripidae) in field-grown pepper. Journal of Economic Entomology, 96(4): 1201-1214

317. REITZ, S.T. 2009. Biology and ecology of the western flower thrips (Thysanopotera: Thripidae): The making of a pest. Florida Entomologist, 92 (1):7-13

318. REITZ, S.R.; FUNDERBURK, J. 2015. Management strategies for western flower thrips and the role of insecticides. Insecticides-pest engineering, 355-384

319. RESENDE, R.0.; DE ÁVILA, A.C.; GOLDBACH, R.W.; PETERS, D. 1991. Comparison of polyclonal antisera in the detection of Tomato spotted wilt virus using the double antibody sandwich and cocktail ELISA. Journal of Phytopathology, 132:46-56

320. RESENDE, R. DE 0.; DE HAAN, P.; DE ÁVILA, A. C.; KITAJIMA, E. W.; KORMELINK, R. 1991. Generation of envelope and defective interfering RNA mutants of Tomato spotted wilt virus by mechanical passage. Journal of General Virology, 72:2375-2383

321. RESENDE, R.0.; PAPPU, H.R. 2020. orthotospoviruses (Tospoviridae). Reference Module in Life Sciences, Elsevier, ISBN 9780128096338. [En línea]. Consultado 20/5/2020. Disponible en https://doi.org/10.1016/B978-0-12-809633-8.21337-X.

322. RILEY, D.G.; PAPPU, H.R. 2000. Evaluation of tactics for management of thrips-vectored Tomato spotted wilt virus in tomato. Plant Disease, 84:847-852

323. RILEY, D.G.; PAPPU, H.R. 2004. Tactics for management of thrips (Thysanoptera: Thripidae) and Tomato spotted wilt virus in tomato. Journal of Economical Entomology, 97(5): 1648-1658

324. ROBERTS, C.A.; DIETZGEN, R.G.; HEELAN, L.A.; MACLEAN, D.J. 2000. Real-time RTPCR fluorescent detection of Tomato spotted wilt virus. Journal of Virological Methods, $88: 1-8$

325. ROCA, E.; ARAMBURU, J.; MORIONES, E. 1997. Comparative host reactions and Frankliniella occidentalis transmission of different isolates of tomato spotted wilt tospovirus from Spain. Plant Pathology, 46:407-415

326. RODRIGUES DO NASCIMENTO, I.; MALUF, W.R.; REIS FIGUEIRA, A.; BESERRA MENEZES, C.; VILELA DE RESENDE, J.T.; FARIA, M.V.; NOGUEIRA, D.W. 2009. Marker assisted identification of tospovirus resistant tomato genotypes in segregating progenies. Scientia Agricola (Piracicaba, Braz.), 66 (3):298-303 
327. ROGGERO, P.; LISA, V.; NERVO, G.; PENNAZIO, S. 1996. Continuous high temperature can break the hypersensitivity of Capsicum chinense 'PI 152225' to tomato spotted wilt tospovirus (TSWV). Phytopathologia Mediterranea, 35: 117-120

328. ROGGERO, P.; MELANI, V.; CIUfFO, M.; TAVELLA, L.; TEDESCHI, R.; STRAVATO, V.M. 1999. Two field isolates of tomato spotted wilt tospovirus overcome the hypersensitive response of a pepper (Capsicum annuum) hybrid with resistance introgressed from $C$. chinense PI152225. Plant Disease, 83:965

329. ROGGERO, P.; MASENGA, V.; TAVELLA, L. 2002. Field isolates of Tomato spotted wilt virus overcoming resistance in pepper and their spread to other hosts in Italy. Plant Disease, 86:950-954

330. RONCO, A.; DAL Bó, E.; GHIRINGHELLI, D.; MEDRANO, C.; ROMANOWSKI, V.; SARACHU, A.N.; GRAU, 0. 1989. Cloned cDNA probes for the detection of Tomato Spotted Wilt Virus. Phytopathology, 79: 1309-1313

331. ROSELLÓ, S.; DÍEZ, M.J.; NUEZ, F. 1996. Viral diseases causing the greatest economic losses to the tomato crop. I. The Tomato spotted wilt virus - A review. Scientia Horticulturae, 67:117-150

332. ROSELLÓ, S.; DIÉZ, M.J.; LACASA, A.; JORDÁ, C.; NUEZ, F. 1997. Testing resistance to TSWV introgressed from Lycopersicon peruvianum by artificial transmission techniques. Euphytica, 98: 93-98

333. ROSELLÓ, S.; DíEZ, M. J.; NUEZ, F. 1998. Genetics of Tomato spotted wilt virus resistance coming from Lycopersicon peruvianum. European Journal of Plant Pathology, 104:499-509

334. ROTENBERG, D.; KUMAR, N. K. K.; ULLMAN, D. E.; MONTERO-ASTÚA, M.; WILLIS, D. K.; GERMAN, T. L.; WHITFIELD, A. E. 2009. Variation in Tomato spotted wilt virus titer in Frankliniella occidentalis and its association with frequency of transmission. Phytopathology, 99:404-410

335. ROTENBERG, D.; JACOBSON, A.L.; SCHNEWEIS, D.J.; WHITFIELD, A.E. 2015. Thrips transmission of tospoviruses. Current Opinion in Virology, 15:80-89

336. RUARK-SEWARD, C.L.; BONVILLE, B.; KENNEDY, G.; RASMUSSEN, D.A. 2020. Evolutionary dynamics of Tomato spotted wilt virus within and between alternate plant hosts and thrips. bioRxiv 2020.01.13.904250. [En línea]. Consultado 6/8/2020. Disponible en: https://doi.org/10.1101/2020.01.13.904250.

337. RUBIO, L.; AMARAL, J.; GONZÁLEZ-ARCOS, M.; ARRUABARRENA, A.; MAESO, D. 2014. Situación actual del virus de la "peste negra" en los cultivos de pimiento del norte del país. En: Programa Nacional Producción Hortícola. Avances de investigación protección vegetal en tomate y morrón. Salto: INIA Salto Grande. p. 2-13 (Serie Actividades de Difusión; 740) 
338. RUFFINELLI, A.; CARBONELL, C.S. 1953. Segunda lista de insectos y otros artrópodos de importancia económica en el Uruguay. Revista de la Asociación de Ingenieros Agrónomos, 94:33-82

339. RUGMAN-JONES, P.F., HODDLE, M.S., STOUTHAMER, R. 2010. Nuclear-mitochondrial barcoding exposes the global pest western flower thrips (Thysanoptera: Thripidae) as two sympatric cryptic species in its native California. Journal of Economic Enthomology, 103(3):877-886

340. SAKIMURA, K. 1962. Frankliniella occidentalis (Thysanoptera: Thripidae), a vector of the Tomato spotted wilt virus, with special references to the color forms. Annals of the Entomological Society of America, 55:387-389

341. SAKIMURA, K. 1963. Frankliniella fusca, an additional vector for the Tomato spotted wilt virus, with notes on Thrips tabaci another vector. Phytopathology, 53:412-415

342. SAlVAlAggIO, A.E.; LOPEZ LAMBeRTINI, P.M.; CENDOYA, G.; HUARTE, M.A. 2014 Temporal and spatial dynamics of Tomato spotted wilt virus and its vector in a potato crop in Argentina. Annals of Applied Biology, 101(1):5-14

343. SAMUEL, G.; BALD, J.G.; PITTMAN, H.A. 1930. Investigations on 'spotted wilt' of tomatoes. Australian Council of Science and Industrial Research Bulletin, 44:64

344. SÁNCHEZ, J.A.; LACASA, A.; GUTIÉRREZ, L.; TORRES, J.; ALCAZAR, A.; GONZÁLEZ, A. 1999. Efecto del arranque de las plantas con síntomas de Tomato spotted wilt virus (TSWV) sobre la incidencia de la enfermedad y la producción en cultivos de pimiento en invernadero. En: CONGRESO NACIONAL DE CIENCIAS HORTÍCOLAS $18^{\circ}, 1999$, España). Actas de Horticultura, 26:264-270

345. SCHNEIDER, W. L.; SHERMAN, D. J.; STONE, A. L.; DAMSTEEGT, V. D.; FREDERICK, R. D. 2004. Specific detection and quantification of plum pox virus by real-time fluorescent reverse transcription-PCR. Journal of Virological Methods, 120:97-105

346. SCHOLTHOF, K.B.G.; ADKINS, S.; CZOSNEK, H.; PALUKAITIS, P.; JACQUOT, M.; HOHN, T.; HONH, B.; SAUNDERS, K.; CANDRESSE, T.; AHLQUIST, P.; HEMENWAY, C.; FOSTER, G. 2011. Top ten plant viruses in molecular plant pathology. Molecular plant pathology, 12(9):938-954

347. SCHOR, N.; BECHAR, A.; IGNAT, T.; DOMBROVSKY, A.; ELAD, Y.; BERMAN, S. 2016. Robotic Disease Detection in Greenhouses: Combined Detection of Powdery Mildew and Tomato Spotted Wilt Virus. IEEE Robotics and automation letters, 1(1):354-360

348. SHARMAN, M. Y PERSLEY, D.M. 2006. Field isolates of Tomato spotted wilt virus overcoming resistance in capsicum in Australia. Australasian Plant Pathology, 35:123-128

349. SHERWOOD, J.L.; SANBORN, M.R.; KEYSER, G.C.; MYERS, L.D. 1989. Use of monoclonal antibodies in detection of tomato spotted wilt virus. Phytopathology,79:61-64 
350. SHERWOOD, J.L.; GERMAN, T.L.; MOYER, J.W.; ULLMAN, D.E. 2003. Tomato spotted wilt. The Plant Health Instructor. [En línea]. Consultado 20/5/2020. Disponible en https://www.apsnet.org/edcenter/disandpath/viral/pdlessons/Pages/TomatoSpottedWilt.aspx.

351. SHIPP, J.L.; GILLESPIE, T.J. 1993. Influence of Temperature and Water Vapor Pressure Deficit on Survival of Frankliniella occidentalis (Thysanoptera: Thripidae). Environmental Entomology, 22 (4):726-732

352. SHRESTHA, A., SRINIVASAN, R., RILEY, D.G., CULBREATH, A.K. 2012. Direct and indirect effects of thrips-transmitted Tospovirus on the preference and fitness of its vector, Frankliniella fusca. Entomologia Experimentalis et Applicata, 145(3):260-271

353. SIN, S.H.; MCNULTY, B.C.; KENNEDY, G.G.; MOYER, J.W. 2005. Viral genetic determinants for thrips transmission of tomato spotted wilt virus. Proceedings of the National Academy of Sciences U S A, 102:5168-5173

354. SMEDA, J.R.; SCHILMILLER, A.L.; ANDERSON, T.; BEN-MAHMOUD, S.; ULLMAN, D.E.; CHAPPELL, T.M.; KESSLER, A.; MUTSCHLER, M.A. 2018. Combination of Acylglucose QTL reveals additive and epistatic genetic interactions and impacts insect oviposition and virus infection. Molecular Breeding, 38: 3. [En línea]. Consultado 13/8/2020. Disponible en https://doi.org/10.1007/s11032-017-0756-z.

355. SOLER, S.; DIEZ, M.J.; NUEZ, F. 1998. Effect of temperature regime and growth stage interaction on pattern of virus presence in TSWV-resistant accessions of Capsicum chinense. Plant Disease, 82:1199-1204

356. SOLER, S.; DIEZ, M.J.; ROSELLÓ, S.; NUEZ, F. 1999. Movement and distribution of Tomato spotted wilt virus in resistant and susceptible accessions of Capsicum spp. Canadian Journal of Plant Pathology, 21: 317-325

357. SOLER, S.; CEBOLLA-CORNEJO, J.; NUEZ, F. 2003. Control of diseases induced by tospoviruses in tomato: an update of the genetic approach. Phytopathologia Mediterranea, 42:207-219

358. SOLER, S.; DEBRECZENI, D.E.; VIDAL, E.; ARAMBURU, J.; LÓPEZ, C.; GALIPIENSO, L.; RUBIO, L. 2015. A new Capsicum baccatum accession shows tolerance to wild-type and resistance-breaking isolates of Tomato spotted wilt virus. Annals of Applied Biology, 167:343-353

359. SRINIVASAN, R.; RILEY, D.; DIFFIE, S.; SHRESTHA, A.; CULBREATH, A. 2014. Winter weeds as inoculum sources of Tomato spotted wilt virus and as reservoirs for its vector, Frankliniella fusca (Thysanoptera: Thripidae) in farmscapes of Georgia. Environmental Entomology, 43(2): 410-420

360. SRINIVASAN, R.; ABNEY, M.R.; CULBREATH, A.K.; KEMERAIT, R.C.; TUBBS, R.S.; MONFORT, W.S.; PAPPU, H.R. 2017. Three decades of managing Tomato spotted wilt virus in peanut in southeastern United States. Virus Research (2017). [En línea]. Consultado 31/8/2020. Disponible en http://dx.doi.org/10.1016/j.virusres.2017.05.016 
361. STAFFORD, C.A.; WALKER, G.P.; ULLMAN, D.E. 2011. Infection with a plant virus modifies vector feeding behavior. Proceedings of the National Academy of Sciences USA, 108:9350-9355

362. STAFFORD-BANKS, C.; ROTENBERG, D.; JOHNSON, B.R.; WHITFIELD, A.E.; ULLMAN, D.E. 2014. Analysis of the salivary gland transcriptome of Frankliniella occidentalis. PLoS ONE 9(4): e94447. doi:10.1371/journal.pone.0094447

363. STAFFORD-BANKS, C.; YANG, L.H.; MCMUNN, M.S.; ULLMAN, D.E. 2014b. Virus infection alters the predatory behavior of an omnivorous vector. Oikos, 123: 1384-1390

364. STAVISKY, J.; FUNDERBURK, J.; BRODBECK, B.V.; OLSON, S.M.; ANDERSEN, P.C. 2002. Population Dynamics of Frankliniella spp. and Tomato Spotted Wilt Incidence as Influenced by Cultural Management Tactics in Tomato. Journal of Economic Entomology, $95(6): 1216-1221$

365. STEINER, M.Y.; SPOHR, L.J.; GOODWIN, S. 2011. Relative humidity controls pupation success and dropping behavior of western flower thrips, Frankliniella occidentalis (Pergande) (Thysanoptera: Thripidae). Australian Journal of Entomology, 50(2):179-186

366. STEVENS, M.R.; SCOTT, J.W.; GERGERICH, R.C. 1992. Inheritance of a gene for resistance to Tomato spotted wilt virus (TSWV) from Lycopersicon peruvianum Mill. Euphytica, 59:9-17

367. STEVENS, M.R.; SCOTT, S.J.; GERGERICH, R.C. 1994. Evaluation of seven Lycopersicon species for resistance to Tomato spotted wilt virus (TSWV). Euphytica, 80: 79-84

368. STEVENS, M.R.; LAMB, E.M.; RHOADS, D.D. 1995. Mapping of Sw-5 locus for Tomato spotted wilt virus resistance in tomatoes using RAPD and RFLP analysis. Theoretical and Applied Genetics, 90:451-456

369. STEVENS, M.R.; HEINY, D.K.; GRIFFITHS, P.D.; SCOTT, J.W.; RHOADS, D.D. 1996 Identification of co-dominant RAPD markers tightly linked to the Tomato spotted wilt virus (TSWV) resistance gene SW-5. Tomato Genetics Cooperative Report, 46:27-28

370. STEVENS, M.R.; PRICE, D.L.; MEMMOTT, F.D.; SCOTT, J.W.; OLSON, S.M. Identification of Markers Linked to Sw-7 a New Tomato spotted wilt virus Resistance Gene, Derived from S. chilense. [En línea]. Consultado 9/9/2020. Disponible en https://tgc.ifas.ufl.edu/\%5C/2007/2007IndividualAbsPDf/Identification\%20of\%20Markers\%20Linked\%20to\%20Sw.pdf

371. STEVENS, M. R. 2009. Localization and mapping of Sw-7, a tomato spotted wild virus resistance gene. Proceedings of the 42nd Tomato Breeders Roundtable, Sacramento, CA. [En línea]. Consultado 9/9/2020.

Disponible en http://tgc.ifas.ufl.edu/2009/Stevens\%20SW7\%20mapping.pdf

372. STEWART, J. W.; COLE, C.; LUMMUS.; P. 1989. Winter survey of thrips (Thysanoptera: Thripidael from certain suspected and confirmed hosts of Tomato spotted wilt virus in South Texas. Journal of Entomological Science, 4: 392-401 
373. STOBBS, L. W.; BROADBENT, A. B.; ALLEN, W. R.; STIRLING, A. L. 1992. Transmission of Tomato spotted wilt virus by the western flower thrips to weeds and native plants in southern Ontario. Plant Disease, 76:23-29

374. STORMS, M.M.; KORMELINK, R.; PETERS, D.; VAN LENT, J.W.; GOLDBACH, R.W. 1995. The nonstructural NSm protein of Tomato spotted wilt virus induces tubular structures in plant and insect cells. Virology, 214:485-493

375. STUKenBeRG, N.; PIETRUSKA, M.; WALDHERR, A.; MEYHÖFER, R. 2020. Wavelength-specific behavior of the Western flower thrips (Frankliniella occidentalis): Evidence for a blue-green chromatic mechanism. Insects, 11:423

376. STUMPF, C.F.; KENNEDY, G.G. 2005. Effects of Tomato spotted wilt virus (TSWV) isolates, host plants, and temperature on survival, size, and development time of Frankliniella fusca. Entomologia Experimentalis et Applicata, 114: 215-225

377. SZOSTEK, S.A.; RODRIGUEZ, P.; SANCHEZ, J.; ADKINS, S.; NAIDU, R.A. 2017. Western flower thrips can transmit Tomato spotted wilt virus from virus-infected tomato fruits. Plant Health Progress, 18:1-6

378. TAKEDA, A.; SUGIYAMA, K.; NAGANO, H.; MORI, M.; KAIDO, M.; MISE, K.; TSUDA, S.; OKUNO, T. 2002. Identification of a novel RNA silencing suppressor, NSs protein of tomato spotted wilt virus. FEBS Letter, 532:75-79

379. TAKÁCS, A.; JENSER, G.; KAZINCZI, G.; HORVATH, J. 2006. Natural Weed Hosts of Tomato spotted wilt virus (TSWV) in Hungary. Cereal Research Communications, 34:685688

380. TENTCHEV, D.; VERDIN, E.; MARCHAL, C.; JACQUET, M.; AGUILAR, J.M.; MOURY, B. 2011. Evolution and structure of Tomato spotted wilt virus populations: evidence of extensive reassortment and insights into emergence processes. Journal of General Virology, 92:961-973

381. TEZUKA, N.; LASA, C. I. 1982. TSWV severely affected tomato crops during Jan.-Feb. 1980. Bulletin of the Vegetable and Ornamental Crops Research Station, A No. 10: 75-79.

382. THOMAS-CARROLL, M.L.; JONES, R.A.C. 2003. Selection, biological properties and fitness of resistance-breaking strains of Tomato spotted wilt virus in pepper. Annals of Applied Biology, 142:235-243

383. THOMPSON, G. J.; VAN ZIJL, J. J. B. 1996. Control of Tomato spotted wilt virus in tomatoes in South Africa. Acta Horticulturae, 431:379-384

384. TOAPANTA, M.; FUNDERBURK, J.; WEBB, S.; CHELLEMI, D.; TSAI, J. 1996. Abundance of Frankliniella spp. (Thysanoptera: Thripidae) on winter and spring host plants. Environmental Entomology, 25: 793-800

385. TORRES, R.; LARENAS, J.; FRIBOURG, C.; ROMERO, J. 2012. Pepper necrotic spot virus, a new tospovirus infecting solanaceous crops in Peru. Archives of Virology, 157:609615 
386. TSOMPANA, M.; ABAD, J.; PURUGGANAN, M.; MOYER, J.W.; 2005. The molecular population genetics of the Tomato spotted wilt virus (TSWV) genome. Molecular Ecology, 14:53-66

387. TSUDA, S.; KAMEYA-IWAKI, M.; HANADA, K.; KOUDA, Y.; HIKATA, M.; TOMARU, K. 1992. A novel detection and identification technique for plant viruses: rapid immunofilter paper assay (RIPA). Plant Disease, 76:466-469

388. TURINA, M.; KORMELINK, R.; RESENDE, R.0. 2016. Resistance to Tospoviruses in vegetable crops: Epidemiological and molecular aspects. Annual Review of Phytopathology, 54:347-371

389. UGINE, T.A.; WRAIGHT, S.P.; SANDERSON, J.P. 2007. Effects of manipulating sprayapplication parameters on efficacy of the entomopathogenic fungus Beauveria bassiana against western flower thrips, Frankliniella occidentalis, infesting greenhouse impatiens crops. Biocontrol Science and Technology, 17(2): 193-219

390. ULLMAN, D.; GERMAN, T.; SHERWOOD, J.; WESTCOT, D. 1995. Thrips transmission of tospoviruses: future possibilities for management. En: Herausgeber: Parker, Bruce L.; Skinner, Margaret, Lewis T, editor. Thrips Biology and Management. Springer US. pp. 135-151

391. ULLMAN, D.E.; MEIDEROS, R.; CAMPBELL, L.R.; WHITFIELD, A.E.; SHERWOOD, J.L.; GERMAN, T.L. 2002. Thrips as vectors of tospoviruses. Advances in Botanical Research, 36: $113-140$

392. ULLMAN, D.E.; WHITFIELD, A.E.; GERMAN, T.L. 2005. Thrips and tospoviruses come of age: mapping determinants of insect transmission. Proceedings of the National Academy of Sciences U.S.A., 102:4931-4932

393. VAN DE WETERING, F.; GOLDBACH, R.; PETERS, D. 1996. Tomato spotted wilt Tospovirus ingestion by first instar larvae of Frankliniella occidentalis is a prerequisite for transmission. Phytopathology, 86:900-905

394. VAN DE WETERING, F.; VAN DER HOEK, M.; GOLDBACH, R.; MOLLEMA, C.; PETERS, D. 1999. Variation in tospovirus transmission between populations of Frankliniella occidentalis (Thysanoptera: Thripidae). Bulletin of Entomological Research, 89:579-588

395. VAN HAPEREN, P.; VOORRIPS, R.E.; VAN LOON, J.J.A.; VOSMAN, B. 2019. The effect of plant development on thrips resistance in Capsicum. Arthropod-Plant Interactions, 13:11-18

396. VAN KNIPPENBERG, I.; GOLDBACH, R.; PETERS, D. 2002. Purified Tomato spotted wilt virus particles support both genome replication and transcription in vitro. Virology, 303:278-286

397. VAN RIJN, P.C.; MOLLEMA, C.; STEENHUIS-BROERS, G.M. 1995. Comparative life history studies of Frankliniella occidentalis and Thrips tabaci (Thysanoptera: Thripidae) on cucumber. Bulletin of Entomological Research, 85 (2): 285-297 
398. VAN ZIJL, J.J.B.; BOSH, S.E.; COETZEE, C.P.J. 1986. Breeding tomatoes for processing. South Africa Acta Horticulture, 194:69-75

399. VERKLEIJ, F. N.; PETERS, D. 1983. Characterization of a defective form of tomato spotted wilt virus. Journal of General Virology, 64:677-686

400. VERNON, R.S.; GILLESPIE, D.R. 1990. Response of Frankliniella occidentalis (Thysanoptera: Thripidae) and Trialeurodes vaporariorum (Homoptera: Aleyrodidae) to fluorescent traps in a cucumber greenhouse. Journal of Entomological Society of British Columbia, 87:38-41

401. WALTERS, D.; HEIL, M. 2007. Costs and trade-offs associated with induced resistance. Physiological and Molecular Plant Pathology, 71:3-17

402. WANG, M.; GONSALVES, D. 1990. ELISA detection of various Tomato spotted wilt virus isolates using specific antisera to structural proteins of the virus. Plant Disease, 74:154- 158

403. WARFIELD, C.Y.; CLEMENS, K.; ADKINS, S. 2015. First report of Tomato chlorotic spot virus on annual vinca (Catharantus roseus) in the United States. Plant Disease, 99: 895

404. WEBSTER, C.G.; STUART, R.R.; PERRY, K.L.; SCOTT, A. 2011. A natural M RNA reassortant arising from two species of plant- and insect-infecting bunyaviruses and comparison of its sequence and biological properties to parental species. Virology, 413:216-225

405. WEBSTER, C.G.; ESTEVEZ DE JENSEN, C.; RIVERA-VARGAS, L.I.; RODRIGUES, J.C.V.; MERCADO, W.; FRANTZ, G.; MELLINGER, H.C.; ADKINS, S. 2013. First report of Tomato chlorotic spot virus (TCSV) in tomato, pepper, and jimsonweed in Puerto Rico. Plant Health Progress (doi:10.1094/PHP-2013-0812-01-BR).

406. WEBSTER, C.G.; FRANTZ, G.; REITZ, S.R.; FUNDERBURK, J.E.; MELLINGER, H.C.; MCAVOY, E.; TURECHEK, W.W.; MARSHALL, S.H.; TAMTIWANICH, Y.; MCGRATH, M.T.; DAUGHTREY, M.L.; ADKINS, S. 2015. Emergence of Groundnut ringspot virus and Tomato chlorotic spot virus in vegetables in Florida and the southeastern United States. Phytopathology, 105:388-398

407. WESTMORE, G.W.; ALLEN, G.R.; WILSON, C.R. 2019. Colour preference and potato cultivar oviposition choice by onion thrips, Thrips tabaci (Thysanoptera: Thripidae). Journal of Asia-Pacific Entomology, 22:25-32

408. WHITFIELD, A.; ULLMAN, D.; GERMAN, T. 2005. Tospovirus-thrips interactions. Annual Review of Phytopathology, 43:459-489

409. WIJKAMP, I.; VAN LENT, J.; KORMELINK, R.; GOLDBACH, R.; PETERS, D. 1993. Multiplication of Tomato spotted wilt virus in its insect vector, Frankliniella occidentalis. Journal of General Virology, 74 (Pt. 3):341-349 
410. WIJKAMP, I. 1995. Virus vector relationships in the transmission of Tospoviruses. PhD thesis. Agric. University of Wageningen, The Netherlands. 143 pp.

411. WIJKAMP, I.; ALMARZA, N.; GOLDBACH, R.; PETERS, D. 1995. Distinct levels of specificity in thrips transmission of tospoviruses. Phytopathology, 85:1069-1074

412. WIJKAMP, I.; GOLDBACH, R.; PETERS, D. 1996. Propagation of Tomato spotted wilt virus in Frankliniella occidentalis does neither result in pathological effects nor in transovarial passage of the virus. Entomologia Experimentalis et Applicata, 81:285-292

413. WILLIAMS, L.V.; LÓPEZ LAMBERTINI, P.M.; SHOHARA, K.; BIDERBOST, E.B. 2001. Occurrence and geographical distribution of Tospovirus species infecting tomato crops in Argentina. Plant Disease, 85:1227-1229

414. WILSON, C.R. 1998. Incidence of weed reservoirs and vectors of tomato spotted wilt tospovirus on southern Tasmanian lettuce farms. Plant Pathology, 47:171-176

415. YUDIN, L.S.; TABASHNIK, B.E.; CHO, J.J.; MITCHEL; W.C. 1990. Disease-prediction and economics models for managing Tomato spotted wilt virus disease in lettuce. Plant Disease, 74 (3):211-216

416. ZITTER, T. A.; DAUGHTREY, M.L. 1989. Tomato spotted wilt virus fact sheet. Vegetable MD on line. [En línea]. Consultado 20/9/2020. Disponible en:

http://vegetablemdonline.ppath.cornell.edu/factsheets/Virus_SpottedWilt.htm. 


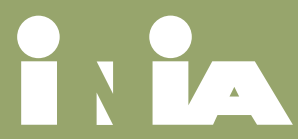

Instituto Nacional de Investigación Agropecuaria U R U U A Y

Edificio Los Guayabos

Parque Tecnológico del LATU

Avda. Italia 6201

Montevideo - Uruguay

Tel.: 26056021

iniaAinia.org.uy

www.inia.uy 